


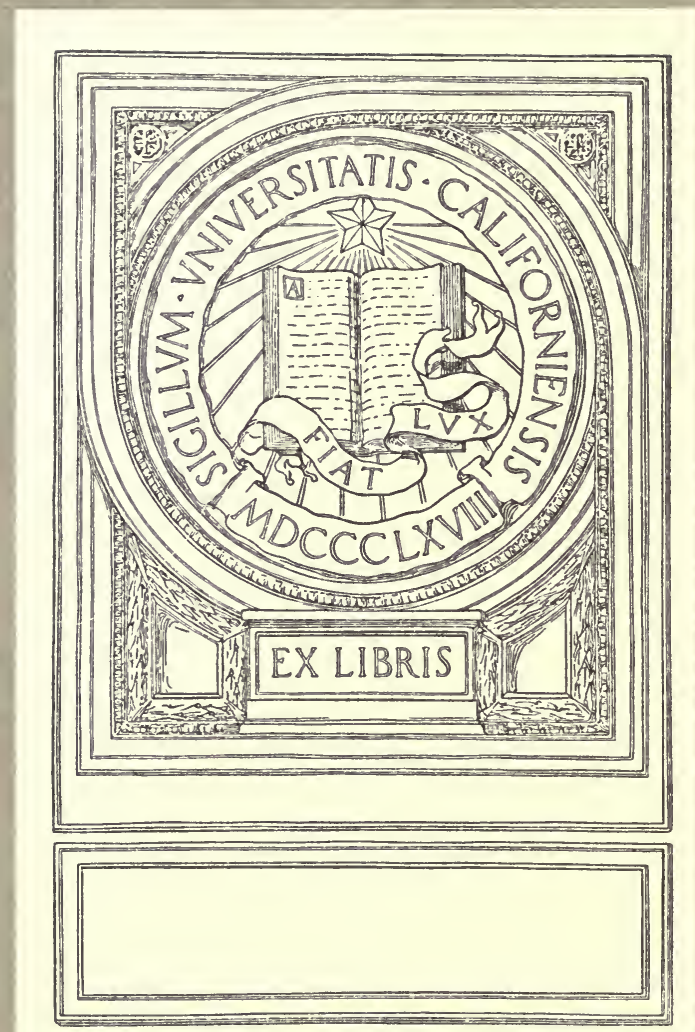



. 
○. 
$\because \because \vdots \quad \because \because \vdots \because \vdots \vdots$

$\therefore \vdots \vdots \because \because \because \because \because \because \vdots \vdots \therefore \cdots$

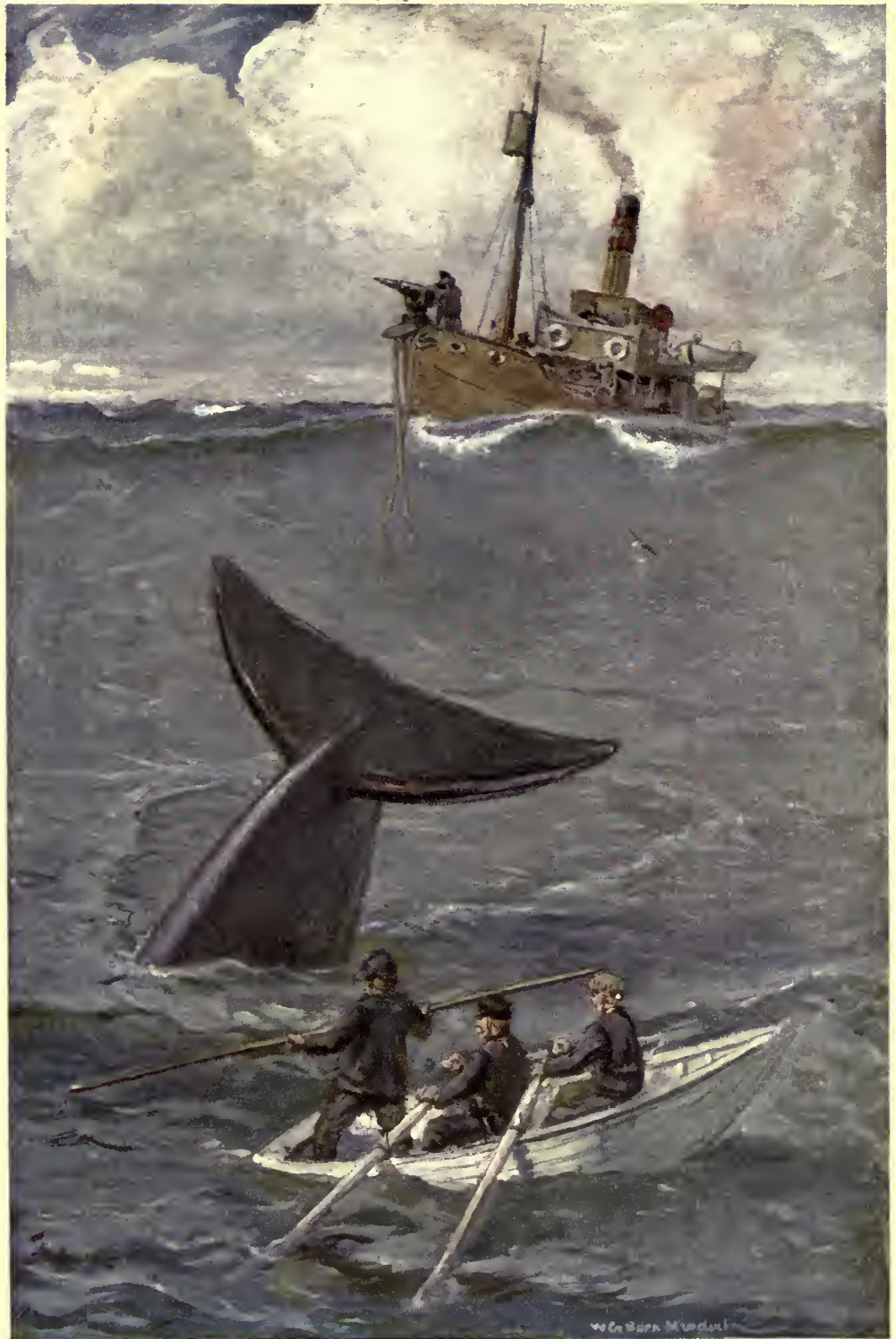

LANCING A WhaLE.

An eighteen-foot spear is the lance half iron half wood. The pram is swung ont; and Jencen is landed the lance. We reach the whale and Jensen makes a lunge, and the spear goes in five fect and is twisted out of his hand; the vast body rolls orer, the tail rises up and np and comes down in a sea of foam. 


\section{MODERN WHALING}

ङั

\section{BEAR-HUNTING}

A RECORD OF PRESENT-DAY WHALING WITH UP-TO-DATE APPLIANCES IN MANY PARTS

OF THE WORLD, AND OF BEAR

AND SEAL HUNTING IN THE

ARCTIC REGIONS

BY

W. G. BURN MURDOCH, F.R.S.G.S.

AUTHOR OF

"FROM EDINBURGH TO THE ANTARCTIC"

"AN ILLUSTRATED PROCESSION OF SCOTTISH HISTORY"

"FROM EDINBURGH TO INDIA AND BURMAH"

$\mathcal{E} c . \mathcal{E} c . \mathcal{E} c$.

With I ro Illustrations

chiefly from Drawings $\xi$ Photographs

by the Author

LONDON

SEELEY, SERVICE छ CO. LIMITED

38 Great Russell Street

I9I7 



\section{PUBLISHERS' NOTE}

7 HE readers of this book will be interested to learn that the expedition from Dundee which set out for 1 the Antarctic regions in $\mathbf{1 8 9 2}$ to the Weddell Sea, south and east of Graham's Land, and in which the author of the present volume took part, was the first of its kind since the famous expedition commanded by Sir James Ross in 1842. Dr W. S. Bruce, the distinguished polar traveller and oceanographer, was the scientific naturalist, and Mr Burn Murdoch, the author of this volume, was the artist and historian of the expedition, which is described by his pen in "From Edinburgh to the Antarctic." It consisted of three whaling vessels specially built of great strength to withstand ice pressure, barque rigged and fitted with auxiliary steam power. They were accompanied by a Norwegian barque of similar type. The chief object of the expedition was the capture of the Right or Bowhead whale by old methods, from small boats. For three months these vessels were continuously amongst the thick pack ice and enormous bergs on the east side of Graham's Land.

The publication of the above-mentioned book, and lectures by Dr Bruce and Mr Burn Murdoch, revived both at home and abroad interest in the Antarctic regions, and in $\mathbf{1 8 9 7}$ the Belgica expedition followed in their wake, and this again was followed by expeditions of various European nations.

During the expedition of 1892-1893 vast numbers of the largest-sized finner whales were observed in the neighbourhood of Erebus and Terror Gulf, and between South Georgia and the South Shetland Islands. The report brought home of these whales being in such numbers led to the development of the present great whaling industry in the Southern Seas. Companies were formed and modern steam whalers 
were sent South to hunt these powerful rorquals or finner whales. The extent of this industry and the methods of modern whaling are described in the first part of this volume.

In the second part, which is concerned principally with bear-hunting in the Arctic regions, some description is also given of the old style of harpooning narwhals from small boats.

The publication of this volume has been held over owing to the war. Part of the text was printed off, and it contains references to events, current at the time, which, without this explanation, might puzzle the reader. The prices of the products of the whaling industry are for the same reason more up to date in the Appendix than in the text. 


\section{LIST OF CONTENTS}

\section{CHAPTER I}

Planning a Modern Whaler-Towing a Whale-Our Whaler, the Haldane, in Shelter-Balta Sound, Shetland-We plan a Company-Our New Whaler, the St Ebba, in Tonsberg

\section{CHAPTER II}

Norway to Tonsberg-Comparison between the Old Viking Ships and our Modern Vessel-Similarity of LinesModern Methods of Whaling-" Modern Whales" compared with Old Style-Whales, Sperm-Right WhalesFinners-Tackling a Finner with Old Style of GearWhaling Stations-Utilisation of Whole Carcass-Whale Products-Modern Whaling in Southern HemisphereStations round the World-Decrease and Increase in Numbers of Whales-Natural Close Season-Increase of Biscayan Whale

\section{CHAPTER III}

In Southern Norway-Building our Whaler-Cutting Lance Shafts - Tanks - Whale Lines - Outfit for Prolonged Cruise-Rigging and Arrangements of Hull-Our Harpoon Guns-The Henriksens of Tonsbeng-Svend Foyn inventor - The Henriksen Works - Early Experiments with Modern Harpoon-Tonsberg Yacht Club-Tonsberg Whaling Captains - Successors of Svend Foyn - Development of Modern Whaling in South Atlantic-Weary Waiting-Trial Run of Engine-Provisioning-At the Rope Factory-Spinning our Whale Lines-Norwegian Hospitality-The St Ebba's First Journey-Studying Charts-The Winch

\section{CHAPTER IV}

Clear St Ebba from Quay Side-Anchor in Sheltered FiordGetting our Fishing Gear, Guns, etc., in order-Adjusting Compass-Final Provisioning-Ammunition-The Islands in the South Atlantic we hope to visit-A Fault in our Accounts-Harpoon Gun Drill . 


\section{CHAPTER V}

Leave South Norway for the Shetlands-Anchors foul-At Sea at Last-Down the Skagerak in Calm-Picking up Lights-Unpromising Weather-Half a Gale-Digging into same Hole-Full Gale-St Ebba a Dry Ship-Hove to-A Sick Crew-Our Cook-Engine will not startDrifting across North Sea to Yorkshire Coast-Recollection of a Previous Whaling Voyage-All Hands to Air Pump

\section{CHAPTER VI}

Drifting-Gale falling-Engines start-Set Sail-The Name St Ebba-We put aside our Plans for Arctic WhalingFair Isle Light - Sumburgh Light-Brassey and Lerwick -Quiet and Greyness of Lerwick-Shetland Anæmic .

\section{CHAPTER VII}

The Waiting Part of Whaling-Before "grassing a Fish"Waiting in Japanese Seas-Poultry on a Whaler-Small Whale Yarn - Tied up in Lerwick - "Customs" on Board - "Tearing Tartan"-Entangled in Red Tape-Are we Pirates ?-A Mass of Fish and Cormorants-Shetlands held in Pawn-A Burly Type of Old Whaler-About the Old Dundee Whaling Captaing-The Registrar braves a Storm-Herring Catchers versus Whalers-British Restrictions on Whaling Industry . . . .

\section{CHAPTER VIII}

Visit to R. C. Haldane at Lochend-Return to St EbbaCaptain Henriksen entertains the Board of Trade Inspector-Registers our Tonnage at Sixty-nine Tons-A Sunday Saturnalia of Shag Shooting-How to cook Shag (Cormorants) - The Quiet of Lochend-Haldane's White House, Peat Fire and Illuminated Missals-Stories-Our Shetland Whaling Station

\section{CHAPTER IX}

Extracts from Whaling Log and Sketch-Book-In ShetlandSea-Trout in the Voe-The Whaler Haldane calls for the Writer-The Forty-Mile Limit-Seals and Birds-The Modern Whale Gun-Difficulty of shooting it-Various Whales-Their Names-Idyllic Sea-A Bad Day for Whaling-Hunting-Freedom of the Sea-Try to blow up Mackerel-Sabbath Calm-No Whales-Fascination of watching for a Blow-Hark back to Shetland-New Departure-A Bag of Wind-Across the Limit againFine Weather-AEsthetics on a Whaler-A Blast, Whales at last! - A Rough Chase-A Bull's Eye at Forty Yards -Lost! 


\section{LIST OF CONTEN'TS}

Better Luck-Spectacular Effect-Whales and Rainbow-On Chase-The Sea teems with Life-Our Chance comesHeart-stopping Excitement-A Close Shave-In Tow -Seventy Tons in the Basket-Ten Whales in a DayVexatious Government Restriction-Uses of Whale Meat, Oil, and some Values in $£$ s. d. . . . .

\section{CHAPTER XI}

Whaling has its seamy Side-A Whale Hunt-Colours of the Sea and Whales-In Tow-Whale is killed-Another Whale-" Thrilling Dangers" of Whaling and Exceptional Behaviour of Whales-Dangers of WhalingWhale Steak-Whale Guano as Fertiliser-Lancing a Whale-Exquisite Colour of Whales-Pedigree of Whales -Rolling Home, Two Whales in Tow .

\section{CHAPTER XII}

Back to the St Ebba on West of Shetland-Fine Weather-No Competition-All Hands busy but no Whales-Our Last Night in Port-Out to the West-The Ramna Stacks as Targets for H.M.S. - A Sailing Ship once more . .

\section{CHAPTER XIII}

A Fine Weather Chantey "California"-Back to LochendCormorant Hash-Up Anchor and leave the Shetlands -Cape Wrath-Lewis-Dunvegan-Picking up LightsSouth to Tobermory-Our West Coast on a Dark Night -Ardnamurchan and Coll-Morar, the Most Beautiful Country in the World-Drimnin next, Glen MorvenTobermory-Relatives and the Lady of Aros Castle .

\section{CHAPTER XIV}

The British Fleet at Oban-A Union Jack made fin Norway -St George versus Imperial Idea-Violation of British Constitution-John Knox a Sunday Golfer-Wives at Sea -A Yarn-A Spy in Tobermory - The Tobermory Police$\operatorname{man}$

\section{CHAPTER XV}

Harvest Moon-Across the Irish Sea-Belfast-Origin of our Name Scotland-Erin go Bragh-What brought us to Ulster Day and the Covenant-The Crew's AdventuresGreenhorns in Ballymacarack Street-Down Channel for the Azores-Spun Yarn-Deep-sea Swell-Inspection of Rifles 


\section{CHAPTER XVI}

N.E. Gale_-"Oot o' this intil a waur"-Into Deep Soundings-It Blows Hard-Black Night and Phosphorescent Wake-Oil on the Waters-Driving through-A Scrap of Sail-Attempt at Dolphin Spearing-A Whale in Phosphorescent Sea-An Idyllic Sunday-A Shoppie or Sale of Clothes from the Slop Chest-AEsthetic Music-Grieg on a Melodeon-M'Crimmon on Practice Chanter-Men who have dreamed-A Demonstration on flensing a WhaleDolphin Steak and Onions-The Islands of the World .

\section{CHAPTER XVII}

A New Land (to us)-St Michael of the Azores-Bens and Glens-Colour of the Island-Portuguese Pilot-Talk by Signs-About Sperm Whales-Ponta Delgada-Its Remarkable Beauty-Arcades-Colour Reflections-The Inner Harbour-Sea Fishing-Bonita-A Trammel NetHunting for Whales round the Island-Distress Signals -The Wreck

\section{CHAPTER XVIII}

Notes about the Island-Compared with Madeira-Its Sights -The Streets of Delgada-A Cafe-Vino Tinto-Guitar Melody - Costumes - Chase Small Whales - Whales' Ocean Routes_" The Ladies' Gulf" . .

\section{CHAPTER XIX}

A Sudden Gale-Driving on to a Lee Shore-Bad NightEngine Trouble - Killers attacking Whale-Recollections of the Antarctic-Oddments-An Eight-Foot Ray or Skate-A Jaunt on Shore-The Writer's Excursion to "The Seven Cities" -Up the Hills-Wind up Affairs in Delgada-Up Anchor

CHAPTER XX

Leave the Azores and San Miguel-Madeira in Prospect and Tunny Fishing-Whales at Last!-Sperm-A ChaseProspects of Success-Long Chase-Fast!-A Straight Shot-A Bull Sperm-Cutting up a Sperm Whale's Anatomy-Sharks-Creeling a Shark Single-handedSpermaceti Oil-Blubber like Marble-Cooking Process£. s. d. on the Horizon-Sharks and Pilot Fish-General Satisfaction-Whaling off Madeira

\section{CHAPTER XXI}

Madeira at Dawn from the Sea - Description - Funchal Flowers-Tunny Fishing_Early Morning Start_Splendid Colours of Native Boats and Crews-Small Fry for Bait-A Large Tunny caught by next Boat-Our Tunny and Pulley-haul Fight-Sailing Back . . 


\section{CHAPTER XXII}

We leave the North Atlantic-Engine Troubles-Slow Voyage PAGE to Cape Town-New Engineer puts Diesel Engine rightUp the East Coast of Africa-The Seychelles Islands -Many Whales-We decide to make a Land StationApply to Government for Licence

\section{CHAPTER XXIII}

Going to the Arctic-Objects in View-Our Little Company in the Fonix-Rough Weather-The First Ice-Draw for Watches-A Party lost in the Ice and a possible Cure for Scurvy-A Lunatic in the Ice-The Coming Spanish Arctic Expedition-Clay Pigeons-Fencing-We aim at Shannon Island-North-East Greenland-Ice Floes and Mist

\section{CHAPTER XXIV}

Arctic Ice compared to Antarctic Ice-Colours of the FloesFirst Blood-Habits of Arctic Seals compared with those of the Antarctic-Stopped in the Floes-Cobalt Ice Water -White Bears" "Protective Colouring"?-Watching a Bear Hunt-Flea of Ursus Maritimus-Scoresby on the Danger of Bear-hunting

\section{CHAPTER XXV}

Six Bears in the Twenty-four Hours-A Bear's Meal-C. A. Hamilton's Veteran Bear-The Writer and a Bear stalk each other-Tips for Animal Painters-Sensation facing a Bear at Three in the Morning-Bear Flesh as FoodThe colour of the Polar Regions-Method of pulling a live Bear on Board-A Bear eating a Seal

\section{CHAPTER XXVI}

Waiting for Whales-Narwhals at last !-Our She-Cook-An Arctic Sanatorium-A Shark-Arctic Seals and Seals of the Antarctic-Our Bear's Food-L'éscrime-Rifle, Pistol, Lasso-Lasso our Starboard Bear-Morning Watch in the Ice-Ivory Gulls, Fulmars, Skuas-Small Life-More Bears-A Bear Stalk before Breakfast-Fears about reaching Greenland-Bears on Board-Caches in Franz Joseph Land-Bear Stories-"The Ends of our Garden"

\section{CHAPTER XXVII}

A Walk on the Floe-Bear takes a Football-Lasso PracticeA Piece of Driftwood-The Bagpipes-Pushing WestA Cold Bath-Chasing a Bear and Cubs-Lost in Mist -Clever Mother Bear-Bear-hunting, a Man killedExpectations of Walrus . 


\section{CHAPTER XXVIII}

A Narwhal and a Bear in the Bag-Missing Whales-Old Style of Whale Gun-Svend Foyn's Cure for ToothacheIs Whaling an "Industry" or a "Speculation"?Whales "Tail up"-Excitement of Whaling-Svend Foyn overboard-Floe Rats-Bears struggle for Freedom - Size and Strength of Bears-The Silence of the ArcticSeals-Painting Ice Effects-Our Gifted Steward and our Vivandiere on the Ice-A Bear on the Floe Edge

\section{CHAPTER XXIX}

Arctic and Antarctic Floes compared-The Writer, the Bear and our "She-Cook"-Bear bids for Freedom-Ropethrowing-An Artist's Points in a Little Seal Stalk-Man and his Works in Arctic and Antarctic-Whales' Food .

\section{CHAPTER XXX}

On Sitting up late-Harp Seals-Young Bears and SeniorsA Family Party-An Ice Grotto-A Hot Grog and Another Bear-A Tight Place. . .

\section{CHAPTER XXXI}

All Hands to secure the Bears-Two Bear Cubs capturedInvidious Comparisons between the Starboard and Port Bear-Another Bear for the Larder-Greenland's Icy Mountains-A Blue Seal- "Starboard" makes more Trouble-A Spanish Yarn-Why the Harp Seal blows its Nose

\section{CHAPTER XXXII}

Sports on the Floe-Notes on Protective Coloration .

\section{CHAPTER XXXIII}

Bear Cubs, "Christabel" and "William the Silent"-Bottle. nose Whales-Bear versus Bull-The Dons back the Bull! -Getting out of the Pack to Open Water-Meet Spitz. bergen Ice

\section{CHAPTER XXXIV}

We get out of the Ice-Open Sea again-Spanish AirsKillers-A Whaler's Esperanto-Killers attacking a Rorquale-A Gleam of Sun-Then Rough Weather-Then Shelter in a Fiord-Beards off and Shore Togs-Our Engineer's Children and the Bagpipes . . 


\section{LIST OF CONTENTS}

\section{CHAPTER XXXV}

Trömso again-Down the Coast-Selling our Bears-Bears

PAGE

Escape-Eat the Fish in Market-place-We put our Bears into New Cages-Notes a mongst the Norwegian IslandsRecollections of Hunting-Fishing-Music-A Viking Air -Talk in the Smoking-room-Drawings of Whale's Structure

\section{CHAPTER XXXVI}

Killers-Stomach of Whales-Grampuses and WhalesWilliam and the Mandolin-The "Prophet"-Hard Waves-Back to Trömso

\section{CHAPTER XXXVII}

Teetotal Travellers-Fate of the Bears-Bears at largeTrondhjem-Folk Songs

\section{CHAPTER XXXVIII}

Whalebone-Whales' Food-Head of Sperm Whale-Value of Whale Oil

APPENDIX

INDEX 


\section{LIST OF ILLUSTRATIONS}

Lancing a Whale

Frontispiece

Piping in the Arctic

24

Modern Whale Gun and Harpoon . . . . 24

Stern View of the St Ebba . . . . . 40

The St Ebba in the Fiord of the Vikings . . . 40

Dead Seal on the Floe Edge $\quad$. $\quad$. $\quad$. 48

Mouth of a Finner Whale $\quad$. $\quad$. $\quad$. 72

Leaving our Two Whales at the Station . $\quad$. 76

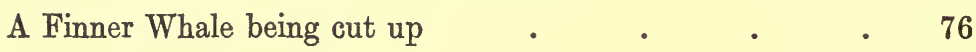

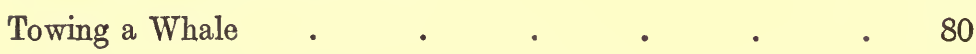

Two Whales being hauled on a Slip $\quad$ - $\quad$. $\quad$. 88

Flensing Blubber off a Polar Bear's Skin . . . 102

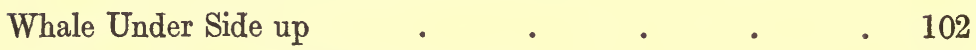

The St Ebba Motor Whaler in Oban . . 112

The Arcades at Ponta Delgada $\quad$ • $\quad$ • $\quad$ • 136

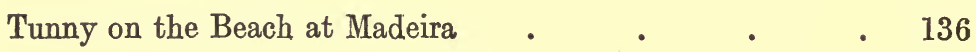

Killers attacking a Finner Whale $\quad$ - $\quad$ • $\quad$. 152

Cutting up a Cachalot Whale $\quad . \quad$. $\quad . \quad 156$

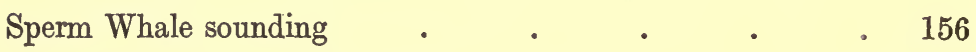

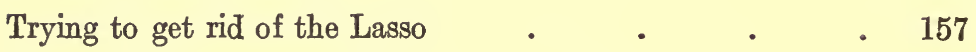

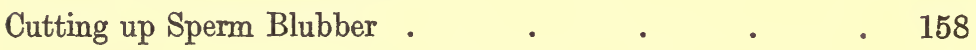

Hauling Sperm Whale's Flipper and Blubber on Board . 160

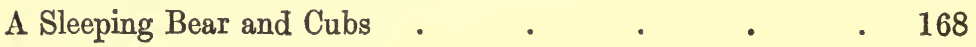


A Dead Bear

Reloading a Gun with a Harpoon . $\quad$. $\quad$ • 192

Towing a big Bear's Skin . . . . . $\quad$. 192

The Last Cartridge . $\quad$. $\quad$. 200

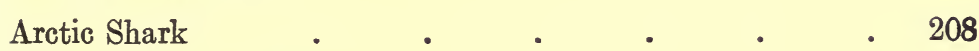

A Modern Steam Whaler . . . . . 208

Fulmar Petrels . $\quad$. $\quad$. $\quad$. 216

Starboard being hauled on Board • • • • • 216

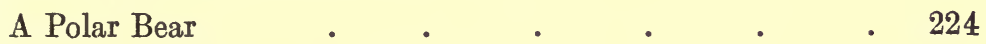

The End of the Trail $\quad$. $\quad$. . 232

Towing Two Bear Cubs . . . . $\quad$. 264

The Captain's Polar Bear Cub . . . . 264

Bears in the Water . $\quad . \quad$. $\quad$. 272

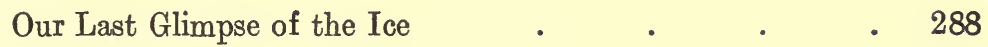

Our Engineer's Daughter • • • • • • • 296

Photo of Starboard .

Species of Whales . $\quad . \quad$. $\quad$. 310 


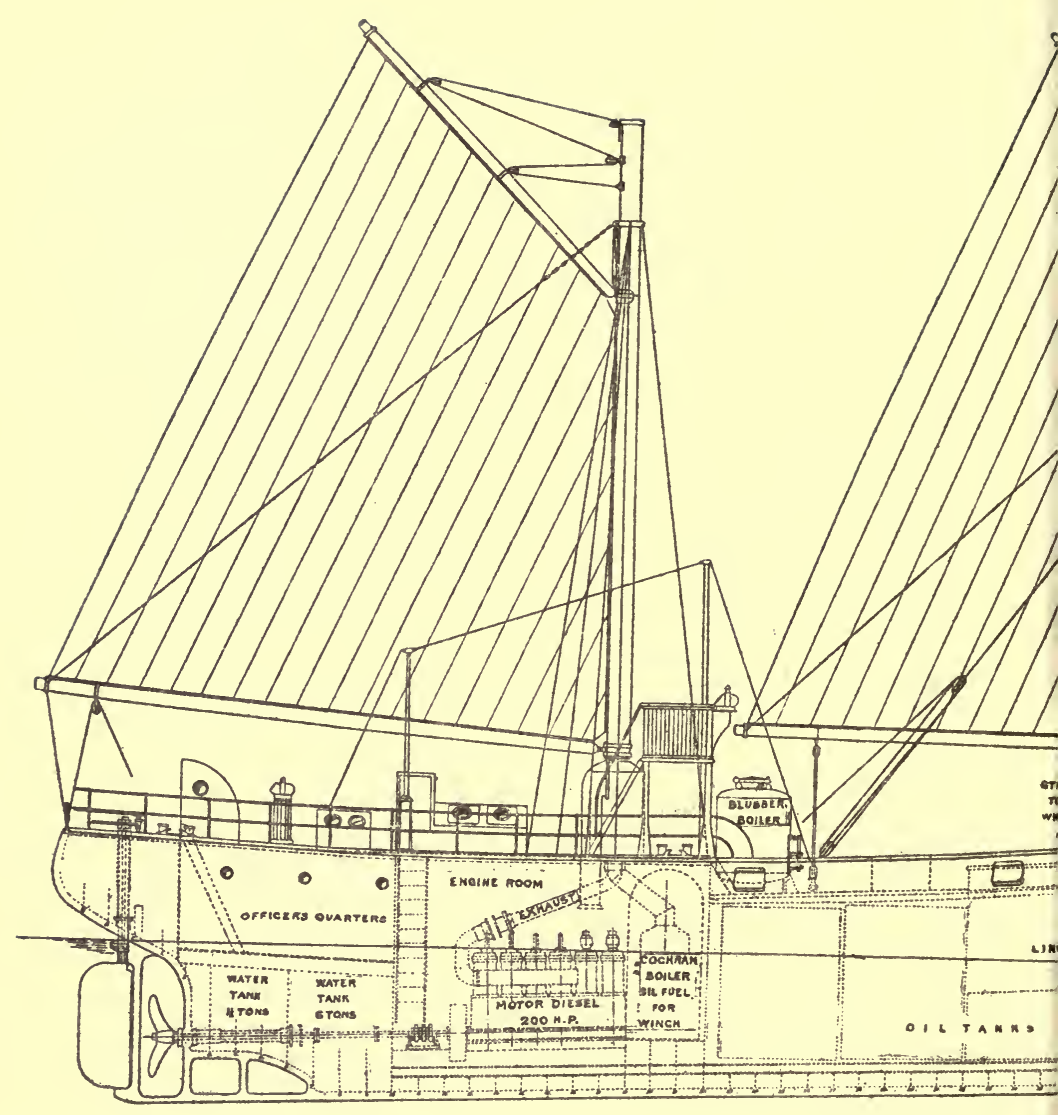

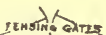

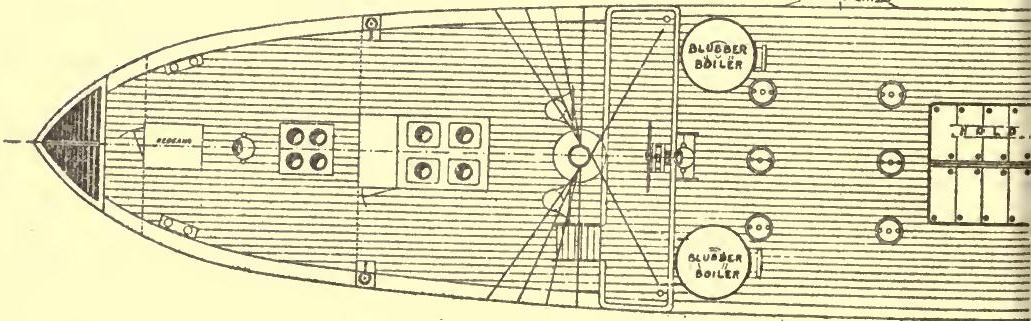



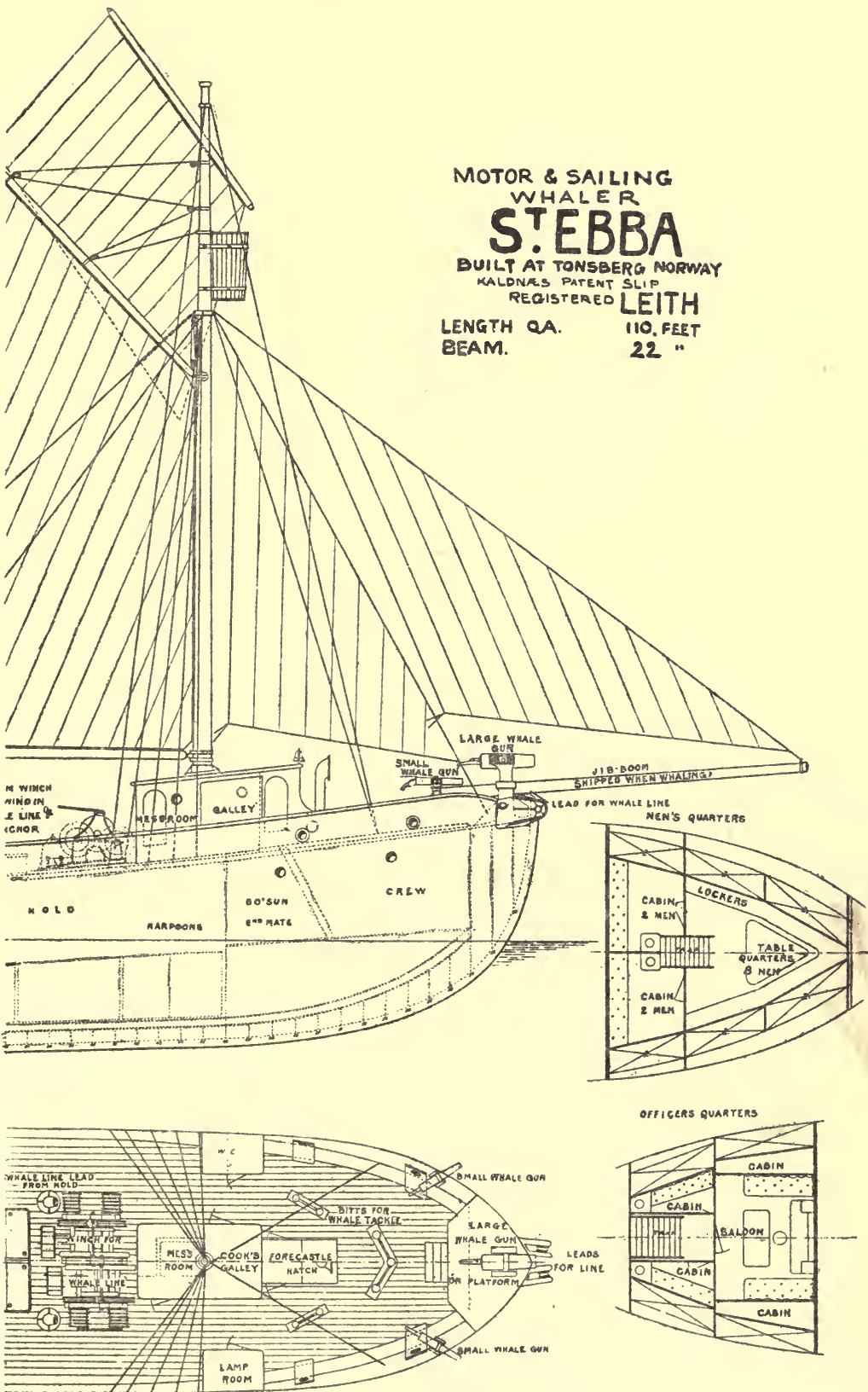



\section{MODERN WHALING AND BEAR-HUNTING}

\section{CHAPTER I}

T T blows, it blows, at Balta Sound, a cold, strong wind, and yet we are in June. I think it always blows at 1 this northern end of Shetland, but we on our little steam-whaler, the Haldane, are sheltered from the sea by the low green shore and the low peaty hills half shrouded in mist.

One after another herring steam-drifters come up the loch and collect round the hulk of a retired sailing-ship to sell their catch on board it by auction. The hull of the wooden ship is emerald-green and the small sombre-coloured steamers crowd around it. On their black funnels each shows its registered number in white between belts of vivid scarlet, blue or yellow.

Our Haldane lies at anchor somewhat aloof from these herring-boats, as becomes our dignity and position, for we are whalers!-in from deep-sea soundings-hunters of the mighty leviathan of the deep, the Balænoptera Sibbaldii, the Balænoptera Borealis, the Balænoptera musculus : commonly called Blue, all of which we call Finners, the largest mammals living or extinct. We are smaller than the herring-drifters. They are a hundred to a hundred and twenty feet long and we are only ninety-five, still we consider ourselves superior : are we not distinguished by a crow's nest at our short foremast, and all the lines of our hull are classic-bow and stern somewhat after the style of the old Viking ships-meant for rapid evolutions, not merely for carrying capacity?

Our colour is light greenish khaki, and if red lead paint and rust show all over our sides, it is an honourable display 
of wounds frum maxy fights with sea and whales-better than herring scales!

We enjoy the enforced rest : all last night we towed a big whale alongside - seventy tons' weight in a rising gale! The bumps and thumps and jerks and aroma were very tiresome.

We towed it ninety miles from the outer ocean to our station at Colla Firth, on Mr R. C. Haldane's property of Lochend, in the early morning (it is light all night here), and left it floating at the buoy, went alongside the trestle pier, helped ourselves to more coal, and slipped away again before the station hands had time to rub their eyes or show a foot.

We came up through the islands, ran to the north of Shetland, passed Flugga light, then turned tail like any common fishing-boat and ran back before a rising gale to this Balta Sound on the east for shelter.

Our little Haldane doesn't care a straw for heavy weather, but we on board her can't harpoon well or manage a whale in heavy seas, so "weathering it out" only means waste of coal.

Therefore we spend the morning in shelter, tramping our very narrow bridge (three steps and a spit, as the sailors say), and we talk and sometimes go into our tiny chart-room and draw; and Henriksen plays Grieg on the melodeon! Henriksen is a whaler by profession, an artist under the skin; and the writer is an artist by profession and harpooneer on this journey from choice and after long waiting.

As we draw and chat we notice with admiration Swedish line-boats like the Norwegian pilot-boat in type, sailing-boats with auxiliary motors, coming up the loch with their sails down, pit-put-a-put, dead in the wind's eyes! We know they have been cod and ling fishing in the North Atlantic for several months, and are now full of fish packed in ice.

"Ah," sighs Henriksen, "if I had a boat half the size of this Haldane, with a motor and crude oil like them, I'd make a good thing of whaling round the world," and the artist agrees, for both have seen many whales in far-away seas. Henriksen knows the Japanese seas where there are Right whales-Australis with bone, and Sperm, or Cachalot, with spermaceti; and the writer has seen sperm in other warm 
seas in numbers, and big Finners or Rorquals in the Antarctic seas by the thousand. So we blow big smokes in the chartroom and draw plans in the sketch-book of a new type of whaler. And she will be a beauty!

The Haldane we are on is second to none of the modern kind of steam-whaler, and we have killed many whales with her up to seventy or eighty tons in weight. But she requires to be frequently fed with coal, and has to tow her catch ashore, possibly one or two whales, or even three at a time, for thirty, forty or even ninety miles to leave them to be cut up at the station.

We plan a vessel that shall be able to keep the sea for a long time without calling for fuel like these Swedish motorboats, and that will hunt whales and seals round the world, and carry the oil and bone of its catch on board.

Can there be any drawing more fascinating than the designing of a new type of vessel for whaling round the world, for warm seas where the grass and barnacles will grow on her keel, and for high latitudes where cold seas and perhaps ice will polish her plates all clean again ?

So after some more whaling and planning, round the Shetlands in fine weather and storm, the writer goes south with rough plans, and in a few days two good men and true have agreed to be directors of a little whaling company; and, the whaling season over, Henriksen goes home to Norway, and with a shipbuilder they draw out our plan in detail, for a new patent Diesel motor-whaler for hunting all kinds of whales and whaling-grounds round the world, a combination of the old style and new, with sails and motor to sail round the world if need be with never a call at any port for food or fuel.

All winter Henriksen the whaler and another Henriksen a shipbuilder toiled at the planning and building of the St Ebba, Henriksen driving every day from his farm five miles into Tonsberg with his sleigh behind slow Swartzen; and the writer pursued his calling in Edinburgh, receiving occasionally fascinating drawings or detail plans of the whaler in white line on blue paper, and then he joined Henriksen in summer in South Norway and both together they drove out and in to 
Tonsberg, behind slow Swartzen, day after day for weeks, till weeks ran into months, and it seemed as if our ship would never be done.

A coal strike in Britain was the first cause of delay, our Colville plates were kept back by that. Still, we had her launched in little more than a twelvemonth from the time we first planned her, which we thought after all was not half bad.

We called her the St Ebba-why, it is hard to say.

It would take volumes to describe the trouble there is in preparing a boat for such a purpose, especially a new type such as ours. Further on in this book the reader will be able to understand from the drawings and descriptions the different styles of whalers of the past and present. 


\section{CHAPTER II}

T N August I went to Tonsberg, the capital of the old Viking days, and over the wooden housetops saw the $1_{\text {two bare pole masts of our ship and a little later }}$ saw her entire hull! How infinitely satisfactory, to see our dream of a year ago in Balta Sound realised in hard iron and pine on the slip. She is one hundred and ten feet over all, with twenty-two-foot beam-just a few feet longer than the Viking ship of the Norwegian princes that was found a year or two ago buried within a mile and a half of where our vessel is being built. Tonsberg was the Viking centre, now it is the centre of the modern whaling industry of the world.

Years ago we thought of whaling as connected with the hunting of whales in the Arctic regions, or of cachalot or sperm whaling in subtropical seas, carried on by sailingvessels which had several small boats and large crews : in the eighteenth century 35,000 men and 700 vessels hunted the Greenland Right whale.

This modern whaling, however, that I write about just now is a new kind of whaling of only forty-eight years' growth. It has grown up as the old styles went more or less out of practice.

Two or three New Bedford sailing-ships still prosecute the old style of sperm whaling south of the line, but the Greenland Right whale hunting has been almost entirely given up within the last two years. The Dundee whalers gave it up in 1912, because this new whaling brought down the price of whale oil, and because the Right whale or whalebone whale, Balæna Mysticetus, had become scarce and so wary that it could not be killed in sufficient numbers to pay expenses.

This Balæna or whalebone whale has no fin on its back.

A large Right whale, or Bowhead, as it is sometimes called, has nearly a ton of whalebone in its mouth, which a few years 
ago was worth about $£ 1500$ per ton ; previously it was worth as much as $£ 3000$ per ton, so one good whale paid a trip. It was pursued from barques like the one below-sailing-ships with auxiliary steam and screw, fifty men of a crew, and small boats, each manned with five men, with a harpoon gun in its bows, or merely a hand harpoon. When the harpoon was fired and fixed into the whale, it generally dived straight down, and when exhausted from want of air, came up and was dispatched with lances or bombs from shoulder guns; they measured from forty to fifty-five feet.

On another page is a small picture of the sperm or cachalot, valuable for its spermaceti oil, and for ambergris, a product found once in hundreds of whales caught. It is a toothed whale and carries no whalebone.

But during the centuries these Right whales and sperm

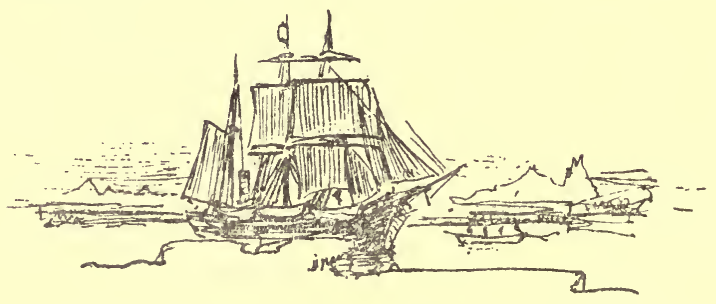

were being killed there were other larger and much more powerful whales, easily distinguished from the "Right whales" by the fin on their backs. These were to be found in all the oceans and were unattacked by men. They have only a little whalebone in their mouths and were much too powerful to be killed by the old methods.

Once or twice the old whalers by accident harpooned one of these "modern whales" or finners, and the tale of their adventure, as told by one of Mr Bullen's Yankee harpooneers, bears out exactly what we ourselves experienced down in the Antarctic, off Graham's Land, in 1892-1893, when one of our men tried to do the same. We had been for months hopelessly looking for Right whale and only saw these big finners in great numbers close alongside of our boats, so one of our harpooneers in desperation fastened to one.

In his book, "The Cruise of the Cachalot," Mr Bullen 
describes sighting a finner whilst they were hunting the more pacific sperm or cachalot. Bullen asks his mentor, a coloured harpooneer, why he doesn't harpoon it, when Goliath the harpooneer turns to him with a pitying look, as he replies:

"Sonny, ef yeu wuz to go and stick iron into dat ar fish yew'd fink de hole bottom fell eout kerblunk. Wen I wiz young'n foolish, a finback ranged 'longside me one day off de Seychelles. I just gone miss'a spam whale, and I was kiender mad-muss ha' bin. Wall, I let him hab it blam 'tween de ribs. If I lib ten tousan year, ain't gwine ter fergit dat ar wan't no time ter spit, tell ye ; eberybody hang ober de side ob de boat. Wuz-poof ! de line all gone, Clar to glory, I neber see it go. Ef it hab ketch anywhar, nobody ever see us too. Fus, I t'ought I jump ober de side-neber face de skipper any mo'."

I have described our similar experience elsewhere-Weddel sea in the Antarctic-with the old-style whaling tackle and a hundred to one hundred and ten foot blue whale or finner. It took out three miles of lines from our small boats-the lines were got hold of from board ship, and the whale towed the procession for thirty hours under and over ice, on to rocks; then the harpoons drew, and it went off "with half Jock Todd's smithy shop in its tail "- our sailor's parlance for its going off with most of our shoulder gun explosive bombs in its lower lumbar regions. These big fellows were so numerous in the ice off Graham's Land that we sometimes thought it advisable to keep them off our small boats with rifle bullets.

Now we can kill these big fellows. Captain Svend Foyn, a Norwegian, mastered them by developing a new harpoon. Svend Foyn and the engineer Verkseier H. Henriksen in Tonsberg worked it out together. A big harpoon fired from a cannon, a heavy cable and a small steamer combined made the finner whales man's prey. Captain Foyn had made a considerable fortune at Arctic seal-hunting, and thereafter spent five years of hard and unsuccessful labour before he perfected his new method in 1868. Eighteen years later there were thirty-four of such steamers engaged in the industry in the North Atlantic, to-day there are sixty-four 
hunting from the Falkland Islands and other dependencies. In the neighbourhood of Cape Horn last year their gross return amounted to $£ 1,350,000$.

These Balænoptera, averaging fifty to ninety feet, are fast swimmers and when harpooned go off at a great speed and require an immense harpoon to hold them, and when dead they sink, and their weight is sufficient to haul a string of small boats under the sea. To bring them to the surface a very powerful hawser is attached to the harpoon, and is wound up by a powerful steam winch on the ninety-foot steamer, which can be readily towed by the whale, but which is also sufficiently buoyant to pull it to the surface when it is dead and has sunk.

In order that a whale may not break this five-inch hawser (or five and a half inches in circumference) the little vessel or steamer must be fairly light and handy, so as to be easily swung round. If the steamer were heavy and slow, the hawser, however thick, would snap, as it sometimes does even with the small vessel when the whale puts on a sudden strain.

In the old style the Greenland whale which floated when it was dead was pulled alongside the sailing-vessel, when the whalebone was cut out of its mouth and stowed on board, as was also the fat or blubber, and the carcass was left to go adrift. The sperm also floats when dead.

But the " modern whales," as I call them, when killed are towed ashore and pulled upon a slip at a station or alongside a great magazine ship anchored in some sheltered bay and are there cut up, whilst the little steam-whaleboat killer goes off in search of other whales. All parts of the body, at a fully equipped shore station, even the blood, of these finners are utilised, the big bones and flesh being ground up into guano for the fertilisation of crops of all kinds, and the oil and small amount of whalebone are used for many purposes. The oil is used for lubrication, soap, and by a new "hardening process" is made as firm as wax and is used for cooking, etc. Some of the whalebone fibre is used for stiffening silk in France, but of these uses of the products we may only give the above indication, for every year or two some new use is being found for whale products. 

Though so large, these whales are not nearly so valuable as the Greenland whale; still their numbers make up for their comparatively small value. ${ }^{1}$

In the last five or six years these finner whales, formerly unattacked by man, have been hunted all round the world. In 1911 there were one hundred and twenty modern steamwhalers working north of the Equator, and in the Southern Hemisphere there were eighty-six. The total value of the catch for the year was estimated at two and three quarter million sterling.

These whales are rapidly becoming more shy and wary, still the catches increase and the value of oil goes up. The more unsophisticated whales in unfished oceans will have soon to be hunted. There is not the least fear of whales ever being exterminated, for long before that could happen, owing to

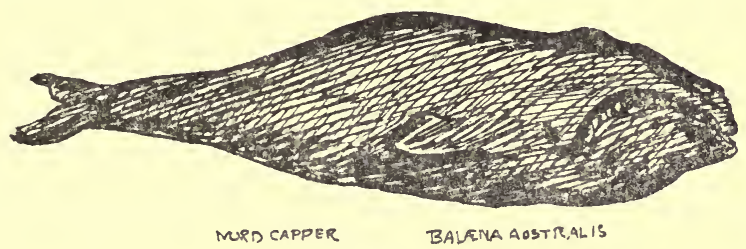

reduced numbers and their increased shyness, hunting them will not pay the great cost incurred. So there will some day be a world-wide close season-just as has happened in the case of the Greenland whale, which is now enjoying a close season and is increasing in numbers in the Arctic seas.

Captain T. Robertson of the Scotia in 1911, though he came home with a "clean ship," saw over forty of the Mysticeti east of Greenland, but could not get near them, for they kept warily far in amongst the ice floes.

The sperm whale is also recovering in numbers. I have seen them in great numbers only last year in warm southern waters, where twenty years ago they had become very scarce.

We must mention here another whale that was actually supposed to be extinct. This is the Biscayensis, commonly

1 Values of whales and their products constantly change. To-day finner whales' oil is becoming almost as valuable as sperm oil. 


\section{6 WHALING AND BEAR-HUNTING}

called a Nordcapper ; it is a small edition of the Greenland Right whale and is practically identical with the Australis of the Southern Seas.

This is the first whale we read of being hunted; in the Bay of Biscay and along the west of Europe it was supposed to have become extinct, but of recent years we have found them in considerable numbers round the coasts of Shetland and Ireland; a few years ago there were, I think, eighty of them captured in the season. 


\section{CHAPTER III}

T $\mathrm{T}$ does not surprise me that the Vikings of the olden days used to leave the southern coast of Norway for summer visits to our Highlands and western isles, for the climate in this Southern Norway in August is most relaxing; there is absolutely nothing of that feeling of "atmospheric champagne" that you expect to enjoy in Northern Norway in summer.

We drive into Tonsberg from Henriksen's farm every morning, and after spending the day in the shipyard, come out again in the evening with our ears deafened with the rattle of steam-hammers on iron bolts, rivets and plates. And at night in the quiet of the country we pore over Admiralty charts of the world, especially those of islands down in the South Atlantic, about which we have special knowledge, where we hope our new whaler will pick up cargoes of whales and of seals.

Our first Sunday off work, 4th August, came as quite a relief, the quiet of the country was so welcome. We wandered through the fields of Henriksen's farm with his wife and their jolly children, and Rex, the liver-and-white collie, smuggled into Norway from Shetland, then through woods and heather till we came by an ancient road to the summit of a little hill and the remains of a Viking watchtower, where we lay amongst blaeberries and heather and enjoyed the wide view of sea and islands at the entrance to Christiania Fiord, a pretty place to dream in and plan raids to the Southern Seas. As we rambled homewards through the pine wood that belongs to the farm we selected fir-trees to be cut down later for boat masts, lance shafts and flensing blades.

By the end of August we realise that our small ship is rapidly approaching completion. What a little while ago was only unkindly iron ribs and plates, with the added 
wood-work of the deck and masts, has now become a little more personal, and more homelike. We have had our engine hoisted from the slipside by a great crane and slowly and tenderly sunk into the engine-room, a very modern sixcylinder Diesel motor made in Stockholm. The fo'c'sle is well aired and lighted, and is fitted up with comfortable bunks and mattresses on wire stretchers. Each man has a long chest beside his bed, for we believe in making the men as comfortable as the after-guard.

The binnacle is now on the bridge, in front of the wheel; its bright new brass looks resplendent; and two hermetically closed boilers we have fixed on deck on either side under the bridge for boiling down whale blubber at sea.

Our hull forward of the engine-room is made up of iron tanks, and in these we hold crude oil for the engine. They will be filled, we hope, by whale oil and whalebone as we use up the crude oil for the engine's fuel.

Above the most forward tanks is the hold, where we shall stow our whale lines-light lines for sperm or cachalot, or the small Right whale, Australis, of the Southern Seas, and our heavy lines for the great fighting finners will be in two bins to port and starboard. Forward of the hold there is the fo'c'sle and men's quarters, with more space under their floor in the peak for more spare lines and sailcloth, and many other necessaries for a prolonged whaling cruise.

We have a small cabin aft, below deck, with four little cabins off it-to starboard, the captain's ; the writer's temporary berth is to port, to be used later for any extra officer or pilot or for stores; the first mate's and first engineer's cabin are a little aft on either side of the companionway.

The iron galley with its small cooking-stove is forward, on deck, and attached to it we have a mess-room, into which four or even five of us can squeeze at one time for meals.

Aft of this mess-room and the foremast we have a very important part of our gear, a powerful winch driven by a donkey steam-engine. This is our reel, to wind up or let out our line, the five-inch cable when we play a finner. The line passes five or six times round two grooved barrels of the 
winch, and with it we haul up to the surface the dead whale. But more about this winch when we tackle a whale.

The 9th of August was a great day for us, for we started our 200 h.p. engines, and drove them at half-speed for an hour and never moved an inch, for the very good reason that our bows were still against the quayside. How quietly and simply they work. We then got our big traveller fixed across our deck for the sheet of our foresail. We are schooner rigged, foresail and mainsail both the same size, and count on doing eight to ten knots with engine, and six or seven with a fine breeze and sails alone.

In the morning we look at our guns in the harpoon factory. The gun or cannon for the bow weighs about two tons. It is already in position; the bollard on which it pivots is part of the iron structure of the bows and goes right down to our forefoot. Its harpoons weigh one and a half hundredweight: we shall take twenty-five of these, and forty smaller harpoons for sperm or cachalot or Right whale. On either side of the bows there is a smaller gun pivoting on a bollard to fire these harpoons. These two small guns and our twenty-five big harpoons and forty of the smaller size we find arranged in order at the works-a charming sight to us. Harold Henriksen, the builder of our ship, takes us to these works, where his brother Ludwig and his father make the harpoons and guns that are now sent all over the world. The father is very greatly respected in Tonsberg; he is called the "Old Man Henriksen," to distinguish him from the younger member of his family. I have already mentioned him as being co-partner with the famous Svend Foyn, the inventor of the new big harpoon for finner whales.

He has made many inventions for marine work on all kinds of ships, for which he has received many medals, and only lately he received a decoration from the hands of his king, which is shown in the portrait given by him to the writer, a rare and highly appreciated gift.

$\mathrm{He}$ is seventy-eight years old and sails his own cutter single-handed. I wish there were space here to tell of his experiences whilst working with Svend Foyn developing 
the big harpoon. He takes us round the works, where forty years of fire and iron have made their mark; remains of failures are there; of burnt building and scrapped metal, but, besides, there are these fascinating stacks of modern harpoons and piles of their shell points to be used for great hunting in all seas.

The "Old Man" chuckles as we wander from forge to forge and out amongst the geraniums in the yard as he tells me how the first harpoon they tried went over the walls of the works and landed through the umbrella of an old lady in the street, and stood upright between the cobblestones. You may believe they practised out of town after that! Though old-seventy-eight years to-day-he is enthusiastic about our new plan of whaling. He has formed a yacht club; everyone yachts at Tonsberg. It is on a small island of little plots of grass between boulders and small fir-trees. We were invited there to-day for the celebration of his birthday. There were ladies in pretty summer dresses in groups, cakes, teas, fruit and pleasing drinks, coffee and cigars, and wasps by the thousands. Norwegian ladies cultivate coolness, and merely brush these away as they hand us cakes and wine; and they would be greatly offended if a man were to attempt to hand tea cakes. For the carpet knight there is no show. I wish he could be exterminated at home. Do the gods not laugh when they see our menkind in frock coats or shooting kit handing tea and cakes to females?

These pretty groups of summer-clad figures amongst lichen-covered rocks and rowans, fir-trees, oaks and honeysuckle were all reflected in the still water. As the sun sank low and a mosquito or two began to sing, fairy lamps were lit amongst the trees, and softly shone on groups of men and women in light raiment in leafy bowers. The light from the yellow and red lamps contrasted with the last blue of day. There was warm air and moths, cards and smokes, and then came music, and a perfect ballroom floor and blue eyes and light feet-a kindly welcome to the stranger in Gamle Norge.

In the dark before dawn, with lighted Japanese lanterns, ladies and men threaded their way over the flat rocks to motor launches and bade good-bye to the hosts. I shall not 
soon forget the long walk home across our island, the low mist, the warm, dark night, and wringing wet fields.

There is one place in Tonsberg of which I must make a note before I come back to our shipbuilding. It is the Britannia. Anyone who wishes to learn all there is to know about modern whaling must get an introduction to that cosy, old-world club. It is a low-roofed wooden house, with lowroofed rooms; one big room adjoins a kitchen, in which broad, kindly Mrs Balkan, wife of my friend the engineer on the whaler Haldane, sits behind a long counter and rules supreme. You leave the shipyard and drop in there for middag-mad, or shelter if it rains. It seemed to rain very often in August. The "old man " Henriksen's portrait and one of the great Svend Foyn are, of course, in evidence, and Svend Foyn's whaling successors come there for middag-mad or aften-mad, and some of them drink, I dare say, a silent skaal of gratitude to the memory of Svend Foyn, who gave them the lead to success, to become small landholders, each with his home, farm, and family.

Burly fellows are his successors, the pick of Norse sailor captains. One is just home from the South Shetlands. I saw these desolate, unhabitated, snow-clad islands many years ago, and saw there finner whales, thousands of them ! and knew they must some day be hunted, but I did not calculate to a penny that there would be over a million pounds sterling invested in whaling stations there to-day; in one bay alone in Clarence Island, and that round these islands in 1911, twenty-two whalers would bag $\mathbf{3 5 0 0}$ whales. So whaling here is an assured industry. In Britain the few who hear about it call it a speculation.

Another ruddy-faced, broad-shouldered, fair-haired captain comes from South Georgia and tells me of my friend there, Sorrensen, the bigger of two big brothers, both great harpooneers-they are both quite wealthy men now. They whaled with us from our Shetland station a few years ago, and between hunts we talked of a whaling station we were going to start in South Georgia; two or three years at this station has set them up for life.

Most of the men who come into the Britannia have been 
over all the world; half-a-life's experience of any of them would fill a book. But of them all I think I'd sooner have my friend Henriksen's experiences. Young as he is, he has perhaps had more experience in whaling than any of them. He was whaling for the Japanese when they opened fire on the Russian fleet. At least he had been-he stopped when the guns began to fire, and took his little whaling steamer behind an island, and he and another Norsk whaling skipper climbed to the top of it and viewed the fight from shelter. I believe they were almost the only Europeans besides the Russians who saw that spectacle. Henriksen has a red lacquered cup-a present from the Mikado in recognition of his services for supplying food in shape of whale to Yusako during the war. In time of peace there they eat the whole whale, paying several dollars a kilo for best whale blubber and as much or little less for the meat.

We in the Shetlands turn the fat oil into lubricants, etc., and the meat into guano for the fertilisation of crops. I suppose it comes to the same thing in the end, if " all flesh is grass."

So the talk, as can be imagined, wanders far afield in the Britannia. I heard a skipper asked by a layman what corners of the world he had been in, and he paused to consider and replied: "Well, I've not been in the White Sea." From Arctic to Antarctic he'd sailed a keel in every salt sea in the world bar the White Sea and the Caspian. The telephone interrupts many a yarn; perhaps Jarman Jensen, our ship's chandler, calls up someone about provisioning a station, say for three years-food, etc., for one hundred men for that time or longer; or perhaps there is a less important order from Frau Pedersen ringing up her husband from their little farm, telling him to call at the grocer on his way home, and he perhaps tells her he thinks he may not get out in time for dinner, and "Oh, buy a house in town, Olaus" is possibly the jesting answer-a great saying here in Tonsberg, where men sometimes are said by their wives to dawdle away the afternoon in the Britannia, when they are really deep in whaling finance, planning whaling stations for islands known, or almost unknown down south on the edge of the Antarctic, or on the coast of Africa or the Antipodes. 
Here is the 12th of August, day of Saint Grouse, and we should be treading the heather at home, but we are still on the island of Nottero, with rain every day; and every morning the same slow drive behind Swartzen into Tonsberg, longing all the time for our ship to be ready for sea. We hoped to have had it ready in June!

We have, however, made almost our last payment, and have her insured. What a lot it all costs !

We tried to console ourselves to-day with the interest of our first trial run of our engine as against loss of pleasant company and grouse at home, also we have the pleasure of seeing the last of our whale lines being made and we get our chronometer on board, stop watch, etc., and spend hoursin Jarman Jensen's little back shop with three skippers giving us advice, as we draw up lists of provisions for the St Ebba for a twelvemonth.

In the rope factory run by Count Isaacksen we watched the last of our great whale lines being spun; three five-inch lines we have to port and three to starboard, one hundred and twenty fathoms each-that is, we can let a whale run out three times one hundred and twenty fathoms on our port lines, three hundred and sixty or two thousand one hundred and sixty feet. I have seen that length run straight out in a few seconds at the rate of sixty miles per hour, with engine going eight knots astern and brakes on, and then it snapped; for some big blue whales five of these lines are attached to give greater weight and elasticity, because, you see, there is no rod used in whale-fishing.

The rope factory and Jarman Jensen's store are two wonders of Tonsberg. The store is a small front shop, generally pretty full of townspeople making domestic purchases, butter, potatoes, coffee. Jensen, with perfect calm and without haste, weighs out a pound of butter, wraps it in paper and hands it with a bow to some customer, gives a direction to one or two heated assistants, and comes back to us in the den behind the shop and continues to tot up the provisioning for our ship for a year, or the stores for some far bigger whaling concern running to thousands of pounds.

So much business done in so small a space and with such complete absence of fuss! Jensen in his leisure hours is 
antiquarian and poet. He possesses a valuable library in Norse antiquities and will write a Saga while you wait. $\mathrm{He}$ must have burned a good deal of midnight oil over the splendid saga he wrote about our St Ebba which was rich with historical reference to the amenities between Scots and the Norwegians in ancient days.

The slowest part of the outfitting for our whaler was, for me, the customary expressions of hospitality. I hope my Norwegian friends will understand and forgive my criticism. It is the result of my being merely British, with only a limited knowledge of Norse and a comparatively feeble appetite. A quiet little dinner given to us as a visitor and representative of our Whaling Company would begin at three P.M. and wind up at ten-eating most of the time-plus aquavit and the drink of my native land, which seems to be almost as popular in Norway as it is in England.

Think of it-five or six hours' smiling at a stretch, pretending to understand something of the funny stories in Norsk and joining in the hearty laughter! I could have wept with weariness. They are to be envied, these Norse, with their jolly heartiness, the way they can shake their sides with laughter over a funny story. The world is still young for them. I remember that our fathers laughed and told long stories like these people.

One chestnut I added as new to their repertoire. I believe it has spread north as far as Tromso, about the man with a new motor who, when asked about its horse-power, drawled in reply it was said to be twenty horse-power, but he thought eighteen of the beggars were dead! And as to speed, it had three-slow-damned slow-and stop! It seemed to translate all right-saghte-for-dumna-saghte, and, Stop! fetched the audience every time. At least it did so when Henriksen told the story, but he is a born raconteur, and infuses the yarn with so much of his own humour and jollity that everyone, especially the womenfolk, who are very attentive to him, laugh till they weep.

A perfect wonder to me is the way in which women here can prepare meals and entertain a lot of people single-handed, or with, say, the help of one maid, at a couple of hours' notice; 
have a spise-brod ready - a table covered with hors-d'œuvres at which you can ruin the best appetite with all sorts of tasty sandwiches, aquavit, liqueurs and beer till the Real dinner is ready, say, of four substantial courses and many wines, custards and sweets. Between times she will possibly see her own children off to bed, probably alongside some of the visitors' children ; then she will sing and play accompaniments on the piano, and join heartily in the general talk, and later will serve a parting meal and a deoch-an-doris, and walk a Scotch escort of a mile or two with the parting guest as the morning sun begins to show.

They seem very jolly though they are so busy. Everyone on this island knows everyone else: they were all at school together, as were their parents before them. Most of the married people have a little farm. The wife looks after this when the husband is at sea-whaling. The women have the vote too! They voted solid a year or two ago for a neatly dressed, plausible young orator who came round the island, and when their husbands came home after the whaling season was over, found he was a Socialist; and if anyone's interests are damaged by the Socialist in Norway, it is the whaler's. So the vote for some time was not a favourite subject of conversation here when ladies were present. I think the wealthiest family in Tonsberg, a millionaire's household, runs to two maidservants.

But this is dangerous ground; let us upstick and board the St Ebba. "Once on board the lugger" we cast off wire hawsers, let on the compressed air with a clash in the cylinders, then petrol, then crude oil, back her, stop her, then motor ahead easily.

The St Ebba's first journey! We passed down between Nottero and the mainland, rapidly passing the small motor craft that seemed to be timing us, travelling at nine and three quarter knots. She seems to go as quickly as our steamwhaler the Haldane-less "send" in calm water. . The Haldane and her like pitch a little, St Ebba makes no turn up behind to speak of at half speed, which is fast enough for actual whaling. She seems particularly quick in turning, and in a very small circle. 
We had charts out all the morning planning our southern route, possibly to the Crozets, possibly the Seychelles or the Antipodes. We have information about whaling in these waters; I wrote our directors about the possibility of running a shore station with St Ebba, and painted the St Ebba flag.

Then we went by our launch, a Berlinda motor-boat fitted with bollard or timberhead at the bow for small harpoon gun for killing sperm or Australis. We found St Ebba's engineer

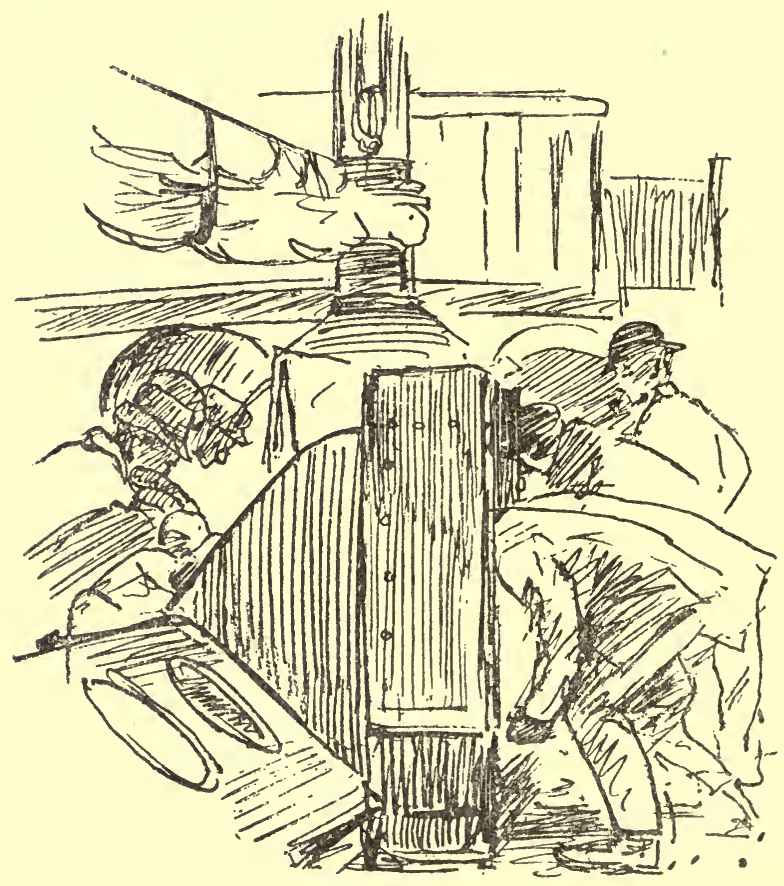

very busy, and worried. The cooling water inflow was stopped by something from outside. The British engineer was also very busy with our Cochran steam boiler for our winch. This winch seems very satisfactory-a sixty-horsepower salmon reel, with ratchet and noise in proportion.

We continued working at the engines till seven P.M., then motored in the St Ebba launch down the side of the island, and got home in the dark at ten-thirty.

I must cut down these day-to-day notes. "Launching a whaler" sounds interesting enough till you come to read 
about details. Little troubles and big troubles and worries arose to delay the getting afloat, signing on men took time, signing off an engineer who got drunk, and getting another in his place caused another delay; and delays occurred getting our papers audited. They had all to be sent back to Christiania to get a " $t$ " crossed or an " $i$ " dotted. Rain came and helped to delay getting our lines on board. Then we had to have an official trip, with representatives of Government, etc., etc., on board, a curious crowd all connected with the sea, most of them captains, a Viking crew on a British ship, still with the Norwegian flag astern!

At the next trip, however, given by us, when we had accepted deliverance, we unfolded the Union Jack and had what I've heard called a cold collation on our main hatch. There were the captain's and friends' relatives, photographers, reporters and skippers all intensely interested in our new type of whaler.

On page $\mathbf{3 6}$ are depicted figures looking into the engineroom, because there was no room inside! There our engineer is discoursing to whaling and mercantile skippers, showing how he can be called from his bunk and have the engine going full speed ahead in less than four minutes; and all the wonders of a modern Diesel motor.

And one by one the carpers climb down, each in his own way-for you see almost all the "men-who-knew" said something or other would happen or wouldn't work. But once they saw our engine work and the arrangement of harpoons, guns, lines, and oil tanks, all of them prophesied success. 


\section{CHAPTER IV}

T last! on the $23 r d$ of August, the St Ebba was ready
to be taken away from the slip, and the town, and the
noise of the builders' yard, and one morning, with rain blotting out the grey stone hills and threshing the trees, and the country a swamp, Henriksen, Mrs Henriksen and the writer went into town for the last time about St Ebba's affairs, motoring in our whale-launch nine knots through the spray. It shows how hard some people are to please, for Mrs Henriksen vowed she preferred her recollection of the motion of a Rolls Royce in Berwickshire on a dead smooth road. Fancy comparing metal springs and the hard high road to the silky rush over spuming surge down the fir-clad fiord, the wind right aft, and each wave racing to catch us.

So we took St Ebba from town and the grime of the quayside and cleaned her decks and laid her alongside a wooden pier a few miles from Tonsberg, brought a flexible pipe on board and filled her tanks with sixty tons of solar oil from an oil refinery, enough to take her at one ton a day to Australia without a call! That went on board in eight and a half hours, one man on watch with his hands in his pockets. How different from the work and dirt of coaling!

Then clang goes the bell for stand by-let go, fore, and aft -half-speed astern and we back away from the pier, with Henriksen on the bridge, our crew young and nimble as kittens and our young mate or styrmand forward alert and the picture of smartness. $\mathrm{He}$ is twenty-one, is Henriksen's brother, and has held master's certificate for three years.

Round we come with the wind out of shelter into rougher sea-half-speed ahead - full speed - and away we go, our first trip with no one but ourselves aboard, no pilot or town ties -ready for a year at sea.

But we have arrangements to make on board yet, arranging 
lines, and guns, and testing them, and a lot of small work with wood which we will do ourselves down the fiord opposite Henriksen's home, a sheltered nook with fir-trees round, five miles from Tonsberg. Knarberg they call this little bay or arm at Kjolo, in Nottero, where long ago Viking ships were built, where Henriksen's father sailed from, and his father before him in the days before steam. Now we revive the past glories with a split-new up-to-date six-cylinder Diesel motor-whaler!

We slide down the fiord before the wind and rain and squalls, smiling with pleasure at our freedom from the wharfside. With a foremast tackle the port anchor is heaved up and hung over the side- the chain stopped by a patent catch ; it is the first time we have gone through the manœuvre in the St Ebba, so even anchoring is full of interest. And in a few minutes more we swing to windward in the narrow Knarberg and drop port anchor and swing to starboard and drop starboard anchor, drop astern and lie where all the winds can blow and never move us.

One anchor might have been enough. But, as Henriksen said to his young brother: "Styrmand, you remember, father always put down two anchors, we will do the same."

Then we open out the foresail and spread it over the boom above the main hatch, and our little crew gets to work, sheltered from the rain, shifting and arranging our goods and chattels below, laying timber balks over the tanks under our main hold so as to form a flooring to support the weight of casks and spare gear, furnace, anvils, lance shafts, etc., that must lie on top.

A glow comes up from the red-painted ironwork on to the faces of the crew that is almost like the effect of sunlight.

Our whaling lines we have to stow away carefully; it takes eight men with a tackle to lift one hank of line on deck, one hundred and twenty fathoms of five-inch rope. And there are stacks of fascinating harpoons, large and small, to be arranged.

We have adjusted the compass to-day by bearings, a long process requiring a specialist down from Tonsberg. The operation gave us a good chance to test our engines- 
so much backing and going ahead and turning in small circles, just the manœuvres we will require in pursuit of whales.

More homely work consisted in getting potatoes on board from Larsen's farm-a retired American naval man-whose farm adjoins Henriksen's. He has cut the spruce shafts in our wood for lances, light and pliable, carefully chosen for the quality of each stem, and so as to leave room for growth of the younger trees. And we have cut down a venerable oak, for we need a stout bole for our anvil, and other smaller pieces for toggles for whale-flensing. Anvil and forge are of goodly size, for we shall have heavy ironwork making straight the big harpoons (three-and-a-half-inch diameter) after they have been tied into knots by some strong rorqual. A turning lathe we must have, and an infinity of blocks, bolts, chains, and shackles. Veritably our little one-hundredand-ten-foot motor, sailing, tank, whaling, sealing, cookery ship is multum in parvo, and parva sed apta.

We have got our ammunition on board. We brought it from Tonsberg yesterday ourselves, on our Bolinder launch, so saved freight and fright! for the local boat-owners were a little shy. Henriksen packed the powder in tins on the floor of our launch in the stern sheets, rifles and cartridges on top, and he himself with his pipe going sat on top of all. I think he smoked his pipe to ease my mind, to make me feel quite sure that he thought it was quite safe, now the ammunition is being stowed away under my bunk! Two thousand express rifle cartridges with solid bullets we have, for we will call on the sea-elephants at a seldom-visited island we know of just north of the Antarctic ice. One load we should surely get in a few weeks' time : their blubber is about eight inches thick, and is worth $£ 28$ per ton; a load of one hundred and sixty tons (I think we could carry as much as that at a

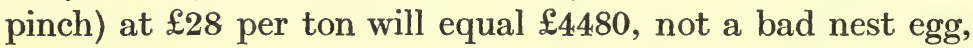
and why not two or three loads in the season, not to speak of the excitement of landing through surf and the struggle through tussock grass. Man versus beast, with the chances in favour of man, but not always; men I know have been drowned, and others nearly drowned, in the kelp and surf that surrounds these islands in the far 


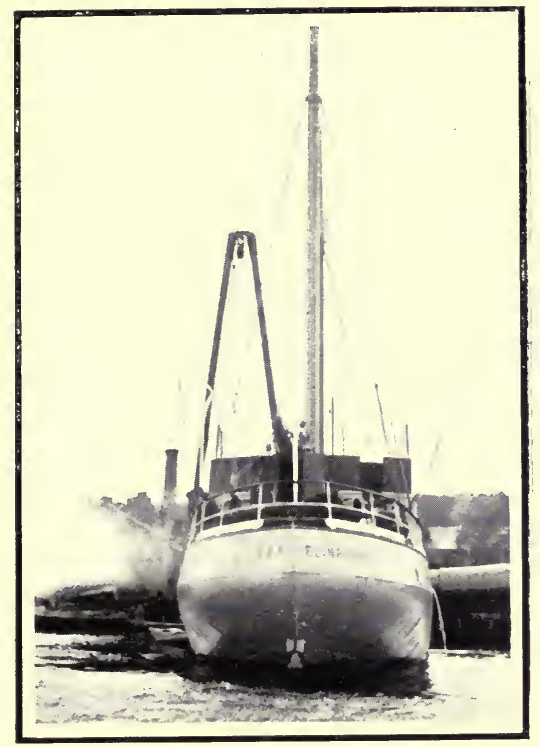

Stern View of the "St. Ebba" at Tonsberg

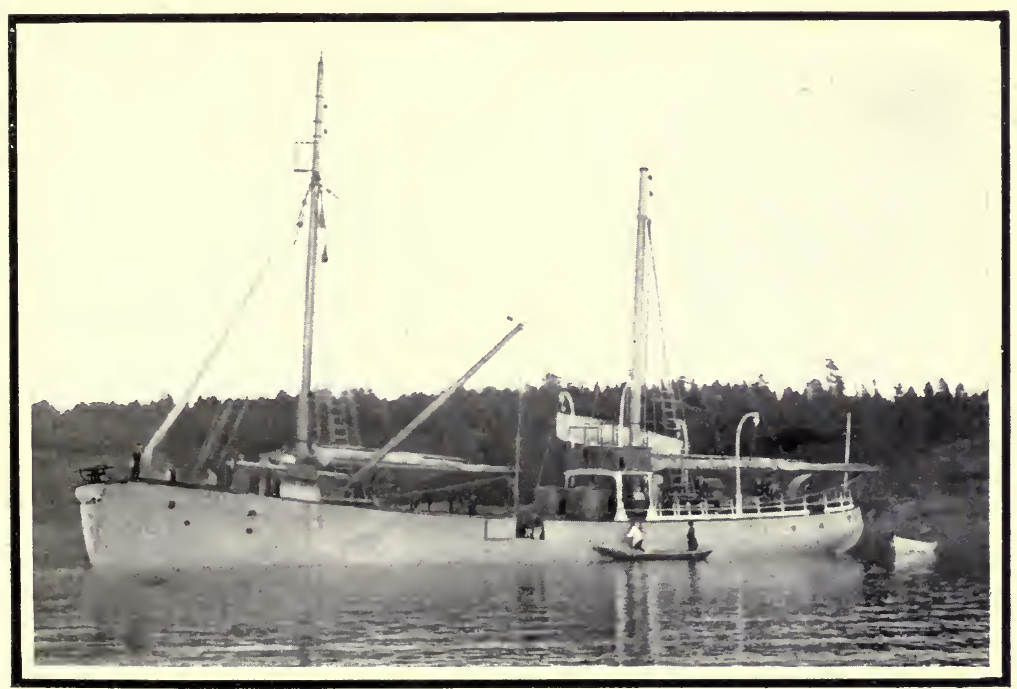

The "St. EbBa" in The Fiord OF THE Vikings 

South Atlantic. Once I had to swim in it, and do not wish to do so again, and it's one bite from a sea-elephant or sea-leopard and good-bye to your arm or leg.

We now have salted ox on board, oxen grown at Kjolo and salted down last winter by Henriksen; and Larsen, the neighbour, brought us vegetables. He is almost a giant, and as he stood in our flat-bottomed dory with two men rowing he made a picture to be remembered, for he was surrounded by lance shafts, sacks of potatoes, red carrots and white onions, so that the dory was down to the water's edge! I prayed she might not upset. Larsen himself stood amidships with three enormous green balloons in his arms-such giant cabbages I have never seen before-each seven-and-a-half kilos (fifteen pounds), in weight, the result of whale guano.

The children of the neighbourhood played on our decks; Henriksen's two boys and daughter soon knew every corner of the ship, just as he learned every part of his father's vessel when he lay at Kjolo, only in those days there were higher masts to climb, and yards to lie out on, and tops to pause in, to admire the view and get courage to go higher. Our crow's nest on our pole-foremast is the highest they can attain to on the St Ebba. The aftermast-or mainmast, I suppose I should call it, as we are schooner rigged-is of hollow iron cut short above the top (this is technical, not a bull); this forms the exhaust from the engine. You see only a little vapour, still, it does seem a trifle odd even to see faint smoke coming out of a mast! We will rig up topmasts in the South Seas, and have topsails in fine winds and the Trades, when we do not need the motor, and will then look quite conventional.

Here is a photograph of some of the children that play on our decks and round about the St Ebba in boats. They are of the sea. "It is in the blood," as Mrs Henriksen replied to me when I asked her how she got accustomed to her husband's long voyages and absence from home. It is their tradition to go to sea, and Elinor, Henriksen's daughter, will be surprised if her brothers William and Henrik do not follow their father to sea in a few years. In ancient days it was the same here, womenfolk thought little of the men who had not done 
four or five years' Viking cruising, gathering gear from their own coast or from their neighbours'.

We hope that this Monday, the 22nd of September, will be our last day on shore, and it rains and rains, and we long for the shelter of boardship where there is no soppy ground or puddles, and there will be the fun of going somewhere instead of inhabiting this one spot of earth for days, till days become weeks and weeks months for ever and for ever without getting anywhere farther.

We have now almost everything on board, books, charts, bags of clothes, but we have still to wait for some spare parts for the engine from the makers at Stockholm, which they advise us to get before going on a southern voyage. We intended to have got away in time to do a preliminary canter, as it were, for whales up north to the edge of the icenot into it-for bottle-nose and finners, so as thoroughly to test our engine and crew before going to the Southern Seas. Now it is too late for that, so we shall only go "northabout" round Shetland, where we may be in time for the last of the whaling season, and then proceed south.

The spare parts of the motor arrived, but it rains and blows a fierce gale from S.W., and we could get out of our fiord but no farther against such a gale, so we cool our heels and Henriksen works at accounts, a serious matter. It is a new departure, a captain acting in so many capacities, manager, navigator, harpooneer, etc.

This is my fifth week of waiting here, the most wearisome time I have ever spent in my life. So much for whale-fishing and its preliminaries! The time actually spent in connection with the ship's affairs passes pleasantly enough, and curiously the sense of weariness goes, once on board. Perhaps getting off clay soil on to salt water accounts for this.

The sea-water in the fiord here stands abnormally high all these days. It came running in two days ago in calm weather. So outside the North Sea and Skagerak we knew it must be blowing hard. To-day, though finer, the fiord water still remains high, so we know from that and the newspapers that there is strong southerly wind outside.

For two days past a cloud has hung over us. Henriksen 
found a deficiency in his accounts, found that the outfit for the St Ebba cost 10,000 kroner more than the receipts vouched for, and went over and over accounts, till yesterday we made another pilgrimage to Tonsberg and interviewed a banker and said politely, "How the deuce can this be?" And he cast his eye over his account-book and found his clerk had merely omitted a figure in addition; a trifle of 10,000 kroner $=£ 550$ ! So we came away smiling, but it gave us a bit of a shake, rather an aggravating and superfluous piece of worry added to vexatious delays and bad weather.

We motored back in the launch much relieved, and on reaching the St Ebba practised big harpoon-gun drill. Henriksen and I are the only men on board who are familiar with its workings, but one or two of the crew have used the smaller bottle-nose or Right whale guns. It was interesting watching Henriksen's demonstration to all hands. Smartly they picked up the drill ; quickly, for all of them have served in the naval reserve or army, and anything to do with a tumble about or small craft they are familiar with from childhood to old age. Yesterday you could readily fancy one of these old Viking fights, for a boatload of ten small boys was fighting another boatload, a free fight, legs and arms in the air, a fearful turmoil, and two boatloads of yellow-haired girls smilingly looked on.

"Old Man Henriksen," the oldest of the Tonsberg inhabitants, came down the fiord from Tonsberg to-night to wish us God-speed. He sailed down in his cutter singlehanded, shot into the wind round our port bow, jibbed and swung alongside round our stern; seventy-eight years old and sailing his home-built, prize-winning twenty-footer as well as the best of his juniors. On board we had the tiniest skaal, which finished our last bottle of whisky, the remnant of our hospitality in the trial trip ; we are drawing our beer and whisky teeth, as the sailors say, before taking the high seas.

Then he went off in the twilight, as the lights began to show in the gloom of the pines on shore, alone, sailing singlehanded, against the wishes of the family, who say he is old enough and rich enough to employ a crew. He will spend 


\section{WHALING AND BEAR-HUNTING}

the night alone on Faarman Holme, at the club he started there; in the morning he will dip his flag to us as we pass.

We all go for our last night on shore, walking home in the dark. Not all-I forgot. William and Henrik are curled up in their father's bunk in great glee at being left to look after St Ebba, along with the crew for its last night in the fiord of the Vikings.

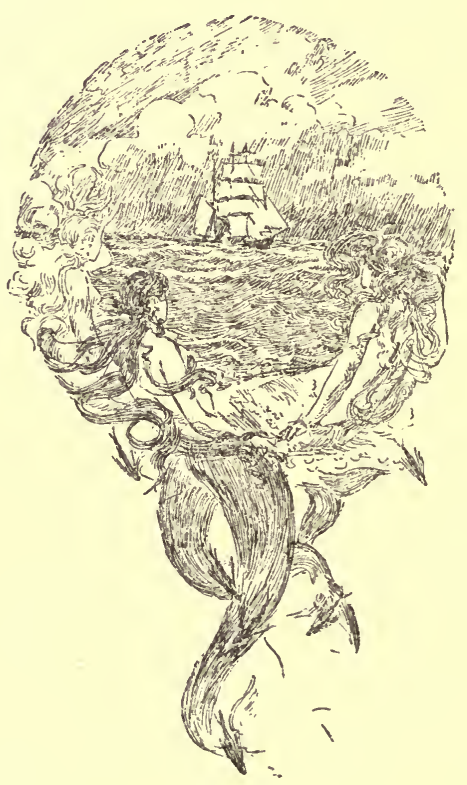




\section{CHAPTER V}

WHEN it's hey! and it's ho! for Scotland, chilly Lerwick and the Shetlands and kindly English-

1 speaking people. My heart warms at the prospect of seeing our western hills and heather and relatives and a language we know.

It rains again, tropical rain. We stand and bid farewell in the homestead, round the little dining-room table, each with a liqueur glass in hand. Suddenly I see eyes are wet, and the stranger nearly pipes an eye too, for it is a bit harrowing even to cold hearts to see married people with children still lovers. My host has been, for him, at home so long, nearly eleven months now! So the parting from wife, children, homestead, farm, woods, horse and hound, all of which he loves, must be sore for however hardened a seafarer.

Our last cargo from home goes to the ship on a hand-cart towed by the children and Rex the collie in great gleecurious luggage-Japanese wicker-work baskets and parcels of foreign-looking clothes for their father. The writer goes ahead with them, leaving the lovers to follow their lone, past the little home they built after Henriksen's first success at whaling, on a three months' spell from sea, down the road and past the school in the birches where they played as children together, down to the brig or rocks where their fathers before them careened their ships and made the same sad partings.

Perhaps the captain is the only sad man to-day. From first mate downwards eyes are sparkling, in spite of the dull day of rain, at the prospect of the rough, bracing, salt seas in front of us. We think nothing just now of cold, wet, dark, dangerous nights; the future is all couleur de rose, whalehunting, new lands and people, sea-elephants, movement and life for us, death to them and profit for us all !

Was it lucky or unlucky that our anchors held to Norway 
and the sea-maids' hair or grass, like grim death ? A sailor would be interested, perhaps, in a description of how the two chains were fouled or twisted, how one shackle opened and the starboard chain went slap into the water. I thought, we are in for more delay, trying to pick it up. But Henriksen spotted that it had caught on the port chain, and his young brother, our mate, promptly slid down it-a nice muddy slide down and to his waist in water-got a rope through its links and stopped it on the port chain, and so we got both back. All the sea fairies of Norwegian seas could not have given us more trouble in taking our British ship from the Norse anchorage.

As we motored from sheltered Knarsberg to Christiania fiord we passed Faarman Holme and the yacht club and dipped our Union Jack, and saw the Norse flag dipped in return, no doubt by old Henriksen, who had stopped the night there to flag us adieu in the morning.

There was more heart-string-breaking before we left. Mrs Henriksen and the children, and Hansen the steward's newly married wifc, came part of the way, and we dropped them a few miles down the fiord in a motor-launch we had in tow. There are tender hearts in Norway, tender and brave.

And now we are out of the great Christiania fiord or firth, passing Færder Light that marks its entrance, Norway faint on our right and Sweden over the horizon to our left, the sun shining for the first day this summer. The sea has a silky swell. We have shaken off all things earthy except a little mud on our anchors now being stowed away, and three or four green oak leaves and moss on the bole of the oak-tree brought for the anvil.

Henriksen and I stand for a little on the bow and rejoice in the heave and send, and compare the movement of St Ebba with that of the Haldane and other whalers we know, and we think that she makes good. There is sun, sea, cloudland, rippling swell and fresh, cold air, with a luxurious roll ; and we feel an hour of such a day at sea is reward for all the months of worry and waiting and planning on shore.

A pleasure in store for us will be setting our new sails. But even now, with the motor alone and fully loaded-with 
sixty tons of fresh water alone-we make nine and a half knots! but with our canvas unloosed and a light breeze behind us might even reel off eleven to twelve.

Not many miles out at sea a Killer (or Orca gladiator) appeared coming from starboard. Our guns were all covered with canvas so we did not clear for action, and the Killer is not of much value. He came towards us and passed forty yards astern, a fact which greatly comforted us, for "those who know" on shore informed us a motor would drive away whales, but how they knew it is hard to say. Then it was said so often, and with such a sense of conviction, that without acknowledging it, we had a slight sense of chill. This Cetacean, a whale of, say, thirty feet, took not the least notice of our crew, and as our fortunes depend on being able to approach the leviathans of the ocean, without frightening them, the incident, though apparently small, gave us considerable encouragement.

Our first day at sea has passed very busily and we go below for a spell to our blankets, early, and tired, but with a joy beyond words at turning in again to a cosy bunk with everything at hand-pipe, books, paints, even music (practice pipe chanter), all within arm's-reach, an open port and chilly, clean air, and the faintest suggestion of movement; such luxuries you may not have on shore.

The sea did not hide its teeth for long. After sundown skirts of rain appeared from threatening clouds on the distant Norse coast. Gradually they spread across our track, bands of little ripples, like mackerel playing, appeared on the smooth swell, and these spread and joined till all the sea was dark with a breeze, which in a few hours grew to a strong wind against us.

As we passed Ryvingen Light on the south of Norway the night grew dismal and rough; we watched its revolving four-flash light, which seemed to be answered by the three flashes we saw lit up the sky from the light on Hentsholme in Denmark, over forty miles to our south, and the gloomy sky over the Skagerak was lit with occasional angry flashes of lightning.

Unpromising weather for our first night at sea! 
By two in the night we were digging into the same hole, making little or no way, with more than half-a-gale from sou'-west.

In the morning we were a very sad lot of whaler sailors. Fore and aft all were sick, or at least very sorry for themselves. All but Henriksen and the mate and the writer and one man were really ill, and we, I believe, only pretended to be well-such is the effect of the motion of a small whaler vessel on even old sailors on their first experience of them. I have known Norsemen who have been at sea all their lives on large craft refuse to go on a modern whaler at any pay.

We aim at getting up the Norse coast as far as Bergen, then going west towards north of Shetlands and, given fine weather, we ought to pick up a whale or two before putting in to Lerwick, where we must re-register our vessel.

But the wind increases to a full gale. All the sea is white and the sky hard, and rain and sun alternate and our nineand-a-half-knot speed is reduced to about four.

But St Ebba is a dry ship. She proves that at least. Any other vessel I have been in, whaler or other, would ship more water than we do.

There is no use trying to steam or motor against this N.-E. gale, so it's up close-reefed fore and mainsail and staysail ; only four men to do it, and that for the first time of this ship at sea, and in a gale. Reef points are made and all got ready; then it's "Haul away on throat and peak" and up goes the scrap of sail, and what clouds of spray burst over the oilskin-clad figures as they haul away cheerily! The writer, at the wheel on the bridge, even comes in for a bit of the rather too refreshing salt spray.

Now the after or main sail is set like a board, and we are transformed into a sailing-ship.

A ring on the bell and the engine and sick engineer get respite; a point or two off the wind and there is the silence of a sailing-ship-no engine vibrations. True, we make little or no progress and some leeway, but the motion is heavenly compared to the plugging away of an engine into a head sea. 


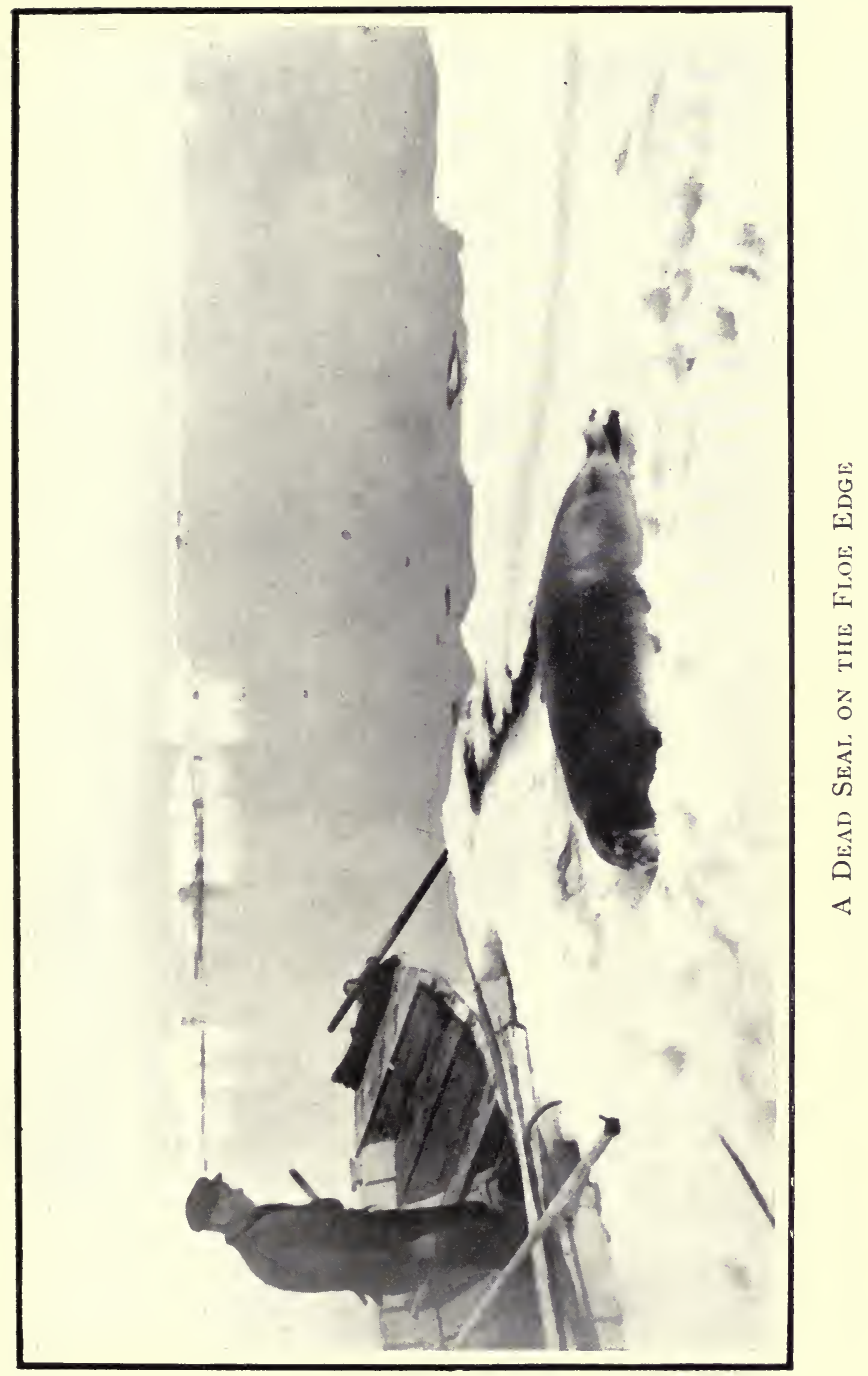



The decks get dry though the sea is very rough, another proof of the St Ebba quality. We wish, however, we were further on our road to " our ain countrie."

The mess-room of St Ebba is not extensive, a little iron house built round the foremast. One third of it is the steward's or cook's galley. He acts both parts. He is almost like a fair Greek, rather thin, with golden hair and a skin as white as his jacket; poor fellow, he is sick, but sticks to his pans, and tries to forget the young wife he left behind him.

His galley is about three feet by six feet beam, and his stove and pans and coal-box just leave him room to stand in. Our mess-room is what I consider a very cosy room for a whaler ; it is fully five feet by six feet beam of iron, grained yellow oak-iron ties and bolts grained like oak. It may not be æsthetic, still in some ways it is the best part of the ship. It seems to be the pivot of our movements. There is a round port-hole or bolley to port, and two looking aft towards our stern and a little round-topped iron door on the starboard. Through the two ports astern comes the sunlight and the iron door keeps out sea and wind, so in this stormy weather our mess-room has its points. There is another round-topped door from it to the galley. So Hansen (cook and steward) has merely to stretch his arm round to us to hand the coffee-pot, or sardines.

Sardines and brown bread are on the table this morning. I notice about two sardines have been eaten by our afterguard, so even if we claim not to be sea-sick we cannot claim any great appetite. Poor cook-he has upset a pail and dishes in the galley. I help him with his stores a bit, but it is no use-he is a bit on edge, so the bridge is the place to sit on and sketch, for one must do something to keep the mind occupied in rough weather. And it is precious cold and comfortless. You have to twist a limb round something to prevent being flung about, steering requires gymnastics.

There is a pale wintry sun, but the air is cold and clammy -all right on shore, I should say, for a September day.

Two masts and a funnel go driving across our track, almost hull down before the gale, a wreath of black smoke dispersing to leeward in wind and spray. I almost regret I am not on 
board, with steam and the wind aft. I'd be in Leith before many hours, then with Old Crow and the dogs on dry stubble. Just the day this for shore, and partridges, or to look for hares on St Abb's Head.

One or two of the crew are reviving this afternoon, though it is still very rough, but the first engineer, a Swede, is still very sick.

One of the crew this morning told me as he steered: "Dem mens forward all seek, but me no seek, so I have six eggs to mineself" ; but he looked pale, and in a minute or two he gave the wheel to me and went to the side of the bridge and came back wiping his mouth with the back of his hand, and took the spokes again, muttering: "Fordumna, now I'se loss dem." Such details of life at sea you find in the Argonautica; they give colour and conviction; only the Argonauts in their days were laid out on the beach with too much purple wine.

Yesterday morning about four we tried the engine, but the Swede could not start it. Either he had let the compressedair supply run out or water had collected and blew into first cylinder or-or-anyway, sick or well, all hands had to pump on till late last night, and only raised pressure to over sixty pounds and it requires to come up to one hundred and fifty.

Henriksen has been saying the wind is going to moderate by such and such a time; when I see a sky such as this round the horizon, with haze and cold, I give several days of gale.

It is very wearisome; Henriksen is pretty quiet. At breakfast we have each half-a-cup of coffee! We are simply drifting across this shallow and somewhat dangerous sea, sometimes called the German Ocean, a crablike course to Yorkshire coast, or will it be St Abb's Head we are to knock against if the wind does not change or the engine go?

It would be an interesting point to get wrecked at, for I've a bet on that the lifeboat a lady started there won't save ten lives in the next ten years. It is only allowed out if the wind is off shore and if the cox first gets her leave. It costs $£ 700$ yearly to keep it up, for motor-slip, man's house and storehouses. Seven hundred pounds per year 
for a lady's whim seems an extravagant way of running the Lifeboat Fund.

With a few hours' lull the engineers would get well, and possibly get the engine air-starting apparatus to work; meantime it is a bit trying having the elements against us, plus engine difficulty, as no engine, no success to our whaling. Thank heaven we have sails; but we must be absolutely sure of our powers of starting the motor, and that at short notice, or St Ebba dare not venture into certain anchorages we hope to visit, such as the east of Crozets and other islands.

Wind always N. by W. ; we are drifting close hauled S.W.

There was watery sunlight this forenoon, now in the afternoon the wind is even stronger, and it is dull with spits of rain, and spindrift ; everything is quivering, and throbbing, with the strain, and we shall have to take in staysail. I think of my first whaling voyage many years ago, when for twenty days we lay hove to, out west of Ireland about Rockall. Days of gale are totting up for this trip now! And yet our waist is full of water only now and then! On that old Balæna, barque-rigged, and twice as big as this little St Ebba, it was knee-deep on an average, and waist-high at times. This boat is marvellously dry ; of course we planned her from a very seaworthy type of boat, the Norsk pilotboat shape such as those we saw come into Balta Sound last year; after they had been three months north of Shetland, they had never taken a drop of sea-water on board, and we think we have improved on them.

As afternoon wore on the wind grew very heavy indeed, and the sea was very high. It was Henriksen's worst experience of the North Atlantic. We watched on the bridge all afternoon, and took in the reefed foresail, so we have only the close-reefed mainsail, and we watched it anxiously lest it should burst. But it is of new strongest sailcloth, Greenock make, and it held.

The watch taking in foresail was a pleasant sight to see. The young fellows, all deep-sea sailors, sprang at the boom like kittens and struggled with the billowing hard wet canvas, tooth and nail, till it was brailed up. I was too cold and wet 
to get my camera, but what a scene, say, for a cinematograph -figures on deck swaying at the halyards and figures clinging pick-a-back to the sail on the boom!

Oh, it was a beast of a day! even though the wave effects were fine; of about five or six I thought each would be our last. But we lay so far over with gunwales under so that we simply shot to leeward with a heavy sea, so there was much "keel water" which, rising from under us to windward, seemed to prevent the waves breaking over our beam.

The crew are all taking turns at air-pumping; they kept at it all day yesterday, and till one o'clock to-day, and we are soon going to see if the pressure will start the engine-it is rather critical. 


\section{CHAPTER VI}

T T $\mathrm{E}$ drifted about ninety miles S.W. in the three days' storm, S.W. of Norway, and now are just the same distance from Lerwick as when we started.

Nine watches with the engine going will take us there.

It is blue and sunny to-day, wind N.E., so we have set staysail and mainsail and go along in a real sailing-ship style.

But the old sea still runs high from N.W. and the wind blows little ripples down the long furrows, and the lumpy waves stop our way down to four or five knots.

In smoother water and with all hands free we would get a jib and topsail on ; meantime we want the engine to work.

At night the blasts became gradually less furious and the seas less precipitous.

At two-forty as I write, rolling along through lumpy blue sea at four knots, the engineer lets on the air all have been labouring at, clash goes the engine, subsiding into its steady business-like stroke, and away we ramp; cheers from some of us. The St Ebba vindicates itself.

How our feelings are changed! "How is the air pressure?" is a question which will be poked at the engineers for many a fine day to come ; and they will take care, sick or not sick, never again to let it run out. We surely do twelve knots with sails drawing and engine running. The log line will soon show. . . .

We run all afternoon finely-sails, wind and motor-till the wind heads us and the foresail comes down, and we roll, roll as I think only a whaler can roll, and the expression on faces changes. But our engineer-mechanicien, we call him-is now no more sick and has the engine going, and is washed and is as spry as usual again.

Evening meal comes (aften-mad) with ship's provender, which is not bad, and what is called tea in Norway; and the 
surges come over our bow and we sit in the tiny galley, Henriksen, styrmand, mechanicien and myself, and St Ebba rolls dishes, pots and pans all about. But what care we, reeling off eight to nine knots against wind with little or no water in our waist ; an ordinary tramp at three knots against the same tumble of sea would be half under water.

Night falls, the Plough lights up, and our pole mast and crow's nest and steamer light go swinging against it.

We ought to sight Fair Isle and Sumburgh Light and Bressay Light, Lerwick, to-night about twelve. The breeze is northerly and for these parts the air is clear and chilly and bracing, giving the energy of the northern electrical condition that we cannot explain but which we know does exist.

We overhauled all our charts this morning in the little cabin after marking our position-a pleasing pastime ; charts are better pictures than the most valued engravings if you have fancy enough to see coral islands and waving palms where are only copper-plate engraved lines. Our Arctic charts we roll away in the very centre of our other charts, for alas, we are now months too late for Davis Straits : the polar bears and white whales and Arctic poppies and the bees humming in the white heather we must visit some other time. These are the happy regions the old whalers speak of with glistening eyes as they recall the joys, the hauls of salmon in nets, the reindeer flesh, and the Right whale hunting. No, no long sunny nights for us this journey. Possibly there will be room for some such description further on in this book, perhaps of whaling and sealing by the light of the midnight sun in the Antarctic or the Arctic.

We must make the best of this northern latitude and get braced up a little with Shetland, which is astonishingly bracing, before going south again. A dip into its cold, salt, crystalline water as you get out of bed is a better tonic than quinine for fever ; and against the grey skies and grey houses of Lerwick and its pale, yellow-haired and kindly people we will picture before us the blue of the south, say the hot side of Madeira with the brown, bare-legged grape-pickers, the sugar cane and the deep blue sea or the hot volcanic dust and fruit at the Azores, the Canaries and Cape Verde, and the 
hunting and waiting for the cachalot or sperm, small game for our big harpoon, but worth much money.

Perhaps we may have a chance down there of Tunny Bonita Sharks and flying fish to put in our bag, and possibly even a turtle.

Fair Isle flashes N.W. at eight-twelve P.M., then Sumburgh Head.

We have been doing eight knots with the wind against us, consuming two tons of oil, from Tonsberg to Shetland, which would have taken sixteen tons of coal.

Then Bressay Light red and white, the night hazy, wind going to S.W. As we come into lee of the island we slow down to three miles an hour, for Lerwick and its light on Bressay Island are only a few miles off and-well, it is just as good fun going into harbour by daylight-so we go slow and the St Ebba's engines start a new chant. This music of our engine we hear sometimes, and do not quite understand. And now Henriksen hears the music ; we lean over the bridge in heavy coats in "the black dark and feen rain," as he calls it, and he hears the singing. Yes, at "Slow" we have the full chorus of voices coming up from the engine-room into the silent night, the general theme a chant, of young voices repeating musically the creed, these change to sopranos, and interludes of deeper women's voices speaking low-toned instructions-then all united! It is just as if we stood at the entrance of some Gothic cathedral at night.

But I leave the fascination of deck and "feen rain and black dark " plus cathedral music to Henriksen and light the midnight oil, and Henriksen hangs on to Mousa green light and dodges fishermen's nets and boats, and in the grey morning tells me it blew up from sou'-west and got very cold.

I was not the least aware of above, as we slipped into Lerwick at five, but yesterday's rapid rise of glass promised as much.

Lerwick at five A.M. in the morning in summer is the same as at any other hour in the twenty-four; it is always light and grey. Green fields and low peaty hills lie behind grey stone houses, and the grey clouds hang low on the hills. The seawater is grey-green. You might call the houses a sort of 
lilac-grey, to be flattering. One or two of them painted white and a black steamer or two on their sea-front give relief to the greyness, and the white steam from their banked fires gives a slight sense of life and joins the grey below to the grey above. Always Lerwick seems instinct with this sense of coming life; here it always seems to be on the point of dawn or beginning of twilight.

Not all the herring-boats, herring men and herring women that congregate here in summer, not even the most brilliant blue summer day, can do away with this twilight; people and boats come and go but Lerwick preserves the same pleasing grey expression of quiet reserve.

To let you into the secret, Lerwick and the Shetlands are slightly anæmic! The best blood of several countries has been flowing into the islands for ages, yet always intelligence remains in excess of physical vigour, always the Scots and Norse say: "Let us go and make use of these islands." "Look at the wealth there is there of sea-fish and sea-birds," says the Norseman, "give me one little island there and I will envy no man." But they forget their starting-points are lands of assured summer, where trees grow (and, for Norsemen, where wild fruit ripens), and they come, and have come, conquering or peacefully hunting, catching sea-trout, whales or herring, and either go away again, or stay, and become like the islanders anæmic, and slightly socialistic, and lose the sense of industrial enterprise, and other people come and take the herring and whales and sea-trout from their doors.

It is greatly a matter of geographical position and climatic conditions. The one tree that grows on the islands could tell you this if you could hear it speak to you of its struggle for existence. 


\section{CHAPTER VII}

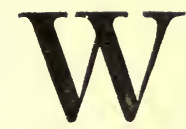

HALING is like salmon-fishing, but the waiting part is on an enormous scale, bigger in proportion than even the game or the tackle, however huge that is. Fancy waiting and fishing for nine months for your first fish. That was my first whaling. Henriksen in Japanese seas on his first whaling command was, I think, a year before he saw a whale. Then he had a lot of shots in succession and missed every time, till he discovered the powder was at fault, and then he killed about ninety in three months.

$\mathrm{He}$ sometimes gives me thumb-nail jottings of his experiences.

Once he ran into port. Yusako, I believe, and the harpoongun on the bows was still loaded, and the Japanese Bos'n fiddled with it and let it off. Two white chickens were resting on the forego (coils of rope under muzzle of gun), and Jap shoemakers, tailors with their goods and chattels, were on foredeck, sitting on the line, and they were all upset by its tautening suddenly. The boom brought Henriksen on deck, he found his bos'n standing pale as china, and a few white feathers floating in the air-a rather Whistleresque picture, is it not? Another time he himself upset all his poultry. He had quite a lot of hens on board, and they rather took to him. He had stood for hours on hours chasing two finners that never gave him a chance of harpooning them, and just at twilight he grew tired waiting and let drive a long shot on chance, never noticing that the fowls had collected round his feet and on the coiled forego. Overboard they went, every hen and chick of them, and great was the retrieving in the pram. ${ }^{1}$

Another curious mistake by a gunner I have heard of. bow.

${ }^{1}$ A pram is a flat-bottomed boat, square stern and pointed saucer 
He'd been chasing for a long time and fired at a whale, as he thought, but could not see where the harpoon went for the smoke. "Have I got the beggar ?" he said, turning round to the Jap at the wheel. "Yes, captain, veree good shot." The smoke cleared and a moak or gull lay with its head off, a bight of the forego had chopped it off ; the Jap on bridge had seen no whale and thought the captain fired at the gull. The gunner's expletives followed, and he threw his hat overboard, and stamped and swore accordingly.

And now here we are tied up, waiting again in Lerwick in September, and on the 1st of June we should have started fishing between Iceland and South Greenland, at a place we know there are certain to be the small but valuable Atlantic Right whale, Biscayensis, or Nord-Capper, as the Norse call it, a small edition of the Greenland Bowhead or Mysticetus (see page 26).

We waited and waited all that August in Norway, our grouse-shooting has gone, and now partridges are going, and we wait still. This last wait is due to an entanglement in red tape, a difficulty in getting our vessel registered here. We have the British Consul's form of registration, a temporary affair from Norway, that has to be renewed here.

Soon after dropping anchor those agreeable and necessary officials, the Customs officers, came on board, in oilskins, which they discarded, disclosing blue jumpers and his Majesty's brass buttons, all showing the effect of the climate, and they set to work overhauling our stores most carefully. If officials are to be maintained work must be found for them and we must all pay; we have assisted the Norwegian and British governments incalculably for weeks and months past. They earn their country's pay by overhauling poor mariners' tobacco and provender, only intended to be chewed and eaten far away in the North or the Southern Seas. Their chief, I knew at once, came from our west or north coast, by his soft accent, which was much to my taste; how much there must be in a voice if it makes even a seafarer almost welcome a Customs officer !

As he opened the stores and checked coffee and tobacco, we "tore tartan" a little. I said my heart was in Argyll but 
my people came from Perthshire, and suggested he might be from Islay. And from Islay he came! the island of Morrisons and whisky. But MacDiarmid was his name. "But that's a Perthshire name," I said. "Yes, yes," said he, "to be sure, from Perthshire my people came." "And from Glen Lyon, possibly?" I said, " and the Seven Kings?" And "Yes, yes," he said, " to be sure, and it is Glen Lyon you know? Well, well, and that is the peautiful glen-and that wull be suxty poonds of coot tobacco, and wan hundred and suxty poonds of black twust. And did you see the Maclean was back to Duart Castle? Aich, aich! it was a ferry fine proceeding! You see, his mother's grandmother's daughter's niece she would come from Glen Islay, and so it wass they came to their own again. Noo hoo much tae will you have here-we must mark it a' doon seeing you may be callin' at another Brutish port or in the back parts o' Mull or maybe in Ireland too."

His junior was Irish, with a Bow Bells accent, and the speech of both was very pleasant to me after months of Norse. The junior leant against the galley door as I had morning coffee, and leisurely interviewed our very busy cook-told him about Lerwick, asked him, "Did yew 'ave a good viyage, stooard ?" to which pale Hansen with the golden hair answered, "Yah, yah, goot," indifferently, but he brightened up when told of the fish to be had in Lerwick. "Wy, yuss, for a shillin' you can git as much 'ere as will feed all 'ands, woy, for a sixpence or fourpence you can git a cod 'ere of saiy fourteen or sixteen pounds!" "Yah, yah, but vill it be goot?" said incredulous Hansen. "Yuss, you bet y'r loife. Ain't no Billinsgaite fish 'ere, matey! wot I mean is you git 'em 'ere 'alf aloive! But did ye git any wyles ?" he continued, "on yer weigh accrost ?" "Wyles?" repeated Hansen. "Wy, yuss, wyles, wyles I say; you're a wyler, ain't yer?" and it dawned at last on Hansen-"Vales! nay, nay, ikke vales-no seed none."

We went ashore with the brass-bounders rowing hard against wind over the fizzling sea amongst hundreds of tame herring gulls, most of them in their young brown plumage, and amongst armies of these sea-robbers, scarts, or 
cormorants, that are here as tame as chickens and numerous as sparrows. Why they are allowed to exist is what we trout and salmon fishers wonder at; in Norway the Government pays fourpence a head. I wish we were as fond of eating them as the Norwegians are.

On shore we got fairly messed up with red tape at the Customs office. The officials were charmingly polite and really wished to be of assistance, but duty first ; and the very young man in authority showed us, with the utmost patience, how essential it was for the interests of everybody that we should be able to prove that the makers of the St Ebba made it really for us, and that the British Consul in Norway should also believe this, and certify that the Norwegian builders had really built it, and also that they had done so to our order, for if they had not done so, it might belong to someone else. Consequently if they, his Majesty's Customs House officers in Lerwick, were to register it as ours, and it wasn't ours, many things might happen, and so on and so forth. And we went back and forward to the ship to get papers and more papers, and each helped, but each and all were smilingly explained to be not absolutely the documents necessary to satisfy his Majesty's Government that-that-we weren't bloody pirates. So give us School Board education and Socialist officialdom and we see the beginning of lots of trouble. Finally, after much pow-wow, we telegraphed the gist of this to Norway, asking the Consul there, in polite language, why the devil he hadn't given us the papers needed to prove we were we, and the St Ebba was the St Ebba, and not another ship, and that it belonged to her owners-that is, to a little private British Whaling Company.

And poor Henriksen, who had spent days and more days getting all these formalities arranged with the Consul in Norway (whilst I used to wait outside under the lime-trees flicking flies off Swartzen), seemed to be almost at breakingpoint of patience, and I wondered in my soul how ships ever got out and away to sea free from red-tape entanglements.

A pleasing interlude and soothing was the pause we sometimes made between ship and office to watch the fish in the clear green water along the edge of the quiet town. The 
water was clear as glass above white sand, and against the low stone quay or sea face were driven, by cormorants, shoals of fish, dark, velvety-green compact masses, of saith or coalfish, actually as thick as fish in a barrel. These ugly dusky divers paid little heed to people on shore, but in regular order circled round the shoals, coming to within eight yards of us, and every now and then one would dive under the mass of fish and fill itself as it went, and an opening through the mass would show its horrid procedure as it straddled across white sand under the fish, till it came up with a bounce at our feet, shaking its bill with satisfaction and then go back to do its turn at rounding up, whilst another of its kind took its turn at eating the piltoch.

No wonder, with this wealth of fish and fowl round the shore, that the Norsemen rather hanker after their old islands; they cure these saith and eat them through winter, and very good they are, and they also eat the cormorants (I give you my word, they are bad; I've eaten many kinds of sea-fowl and the cormorant is the worst). The reader may have heard that Norwegians claim the Shetlands, for they say Scotland only holds them in pawn, for the dowry of Margaret Princess of Denmark, wife of King James III., estimated at 50,000 florins, which has not yet been paid. So when Norway offers the equivalent, plus interest, which now amounts to several million pounds sterling, the islands may be returned to Norway. Possibly international law, recognising the amalgamation of the two companies, Scotland \& Co. and England \& Co., into Great Britain \& Co., may not now admit the claim.

A specimen of a really stout Shetlander came on board with the Customs House men, Magnus Andersen, a burly, ruddy type, not so intellectual or finely drawn as the typical Shetlander-a pilot by profession-what seamen call a real old shell-back, with grizzled beard and ruddy cheeks-about a hundred years old and straight as a dart, stark and strong, with a bull's voice and a child's blue eyes. I said: "Why don't you have an oilskin on ?" It was raining a little and blowing. "I've been at sea all my days," he said, smiling, "and never wore an oilskin"; one of the old hardy school, 
with a look of "Fear God, but neither devil, man, nor storm."

He spoke of all the lines he'd been on-old flyers like the Thermopylæ, and others, sailing cracks that we read of, Green \& Smith companies, and the old tea traders, and then he told me he had been at the Greenland whaling, and mentioned a Captain Robertson, and I said: "D'ye mean "Café 'Tam"?" and he looked at me with a little surprise, but was so pleased to hear the nickname of his old skipper. "Why," I said, "I was with him on board his last ship, the Scotia, in Dundee, not a year ago, and, bar a slight limp, he's as good as a two-year-old." And from that we started off yarning for as long as there was time, which was not much. Old "Bad-Weather" and B-Davidson I asked about. He knew them from their boyhood : old B.-W. came here to Lerwick on his last voyage and ordered Magnus on board. He was to go whether he did a hand's turn of work or not. Magnus admired B.-W., even though he had the common failing; but now he has gone — ? may peace be with him. Magnus blamed the steward and mate for his end, on that last voyage, blamed them for not having his temptation in greybeards thrown overboard. My opinion is that the ice finished him. Take a boy as a mill hand and let him struggle through the fo'c'sle to be bos'n-second mate-first mate and master, then keep him whaling year after year with ice perils and whaling problems and the intense strain and excitement of Arctic ice navigation, and he must die before seventy! Ice navigation is a severe strain.

I've known of a strong man, a Norwegian skipper, who when he saw the ice for the first time, and got his vessel well into it, was so scared that he locked himself into his cabin and was fed through the skylight for a week!

Another old whaler (I mean this time a man of thirty-five) I met in Lerwick. I heard he wanted to see me, for he said he had been a "shipmate" of mine; "shipmate" to one who only plays hide-and-seek with the sea sounded rather pleasant, so we shook hands very heartily for a few seconds, but we had no time for a "gam," for I had to go about our business with these horrid Custom affairs. He seemed to be 
doing well; he had some harbour office and was neatly dressed-his name was Tulloch. I must meet him again and have a yarn when there is more leisure.

We have additional worry here besides the registration. We have to have our vessel remeasured to satisfy our Board of Trade. I fear it gave the registrar some trouble to come from Aberdeen in rough weather, and he was very sick ; if his eye ever falls on these lines, here are my thanks and sympathy. If we had gone to him at Aberdeen he would have put us into dry dock and kept us for weeks, but here we knew there were no dry docks.

At this point in our proceedings the writer left the St Ebba and took the high road over the island, and left the measurement business to Henriksen, for that is a matter that required tact and patience rather than the English language. I went to see my friend R. C. Haldane, who has the property of Lochend on Colla Firth, also to see our Alexandra whaling station there, of which this writer is a Director. I hardly dare mention this in Lerwick for the herring-fishers are jealous of whalers-whaling, they say, has spoiled their herring-fishing-and yet the herring-fishing is better than it ever was! The fact is, if the Man in the Moon made a halfpenny more than they did, at his trade, which I am told is cutting sticks, they would eat their fingers off. Being numerically superior to us whalers they carry the vote-and so our Government has forbidden us to kill whales within forty miles of our Shetland shores during the best of the season, whilst any Dane, Dago or Dutchman may kill them up to the threemile limit! 


\section{CHAPTER VIII}

THAVE just come over the island and on board ship after a week-end trip to the north of this main island to my L friend R. C. Haldane, of the distinguished family of that name, associated in historians' minds with Halfdan the Viking leader, and to newspaper readers with a younger brother-late War Minister and present Lord Chancellor. I came over the island in a single-cylinder motor-car, a splendid new departure for these parts, over the windy, wet moorland track, four hours to do forty miles, but what glorious speed compared with only the other day, when we stiffened for long hours doing the same journey in a slow dog-cart.

The old whaler, Magnus Andersen, took me off to St Ebba in the wind and dark and splashing sea in a leaky cobble.

How jolly and cheery it is to be back in the cosy, lamplit cabin. The first mate is busy at his log, trying to write in English, and soon there is the bump of a boat alongside, and down the companion-way comes our burly youth of a captain, and what a hearty handshake he gives, as if we had been away for weeks, or months, instead of only a week-end : and we compare notes. His day has been full to overflowing.

He had prepared the fatted calf - tinned meat and fish balls and beer, and whisky and soda, against the Board of Trade inspector's visit for measurement and registration; and then he turned out to be a teetotaller and vegetarian! We had telegraphed to Aberdeen for this poor man and he had torn himself from the bosom of his family, faced two days' gale and arrived white as paper and rather on edge. But he was profoundly clever, all admitted that, and he was impressed with Henriksen's books in the cabin, three big shelves, all of them scientific sea-books, and directories. And he said : "Where are the novels ?" And there were none! At least there were none visible. I have two or three about heroes 
and heroines of Park Lane and country mansions, into which I sometimes dip a little just to give renewed zest for the wide horizon and the tang of wind and sea out-by. And he measured this and that, and, much to our joy, he practically accepted the Norwegian Lloyd registration, and put us down at sixty-nine tons instead of a larger figure, which we feared; now, registered as under seventy tons we need not have pilots, and we save in many ways on entering port.

Sunday afternoon with Norwegians is a playtime and holiday, so our master and mates and engineers had a Saturnalia of shag or cormorant shooting and rather shocked the natives of Lerwick who heard the shooting. Our men rejoice more heartily at banging down these marauders than you and I, gentle reader, would rejoice at clawing down the highest birds in Britain, and we all eat them. To cook them, we skin them first, then lay breast and limbs, without the back, in vinegar and water for a night, and wash them in milk and water next morning, then they are stewed; there is a good deal of trouble taken with the cooking, and when done they are extremely bad to eat!

My Sunday, however, was passed in unbroken peace and quiet at Lochend on the west of Shetland. There is a silence at Lochend and on the silvery shingle beach, and over the crystalline rippling green bay that is astounding; a bee humming over the patch of yellow oats sounds quite loud, and a collie barking in the distance beside one of the grey thatched cottages sounds quite close. Haldane's white, thickwalled stone house looks out on to a silvery shingle that makes a perfect crescent between a fresh-water lake of brown peaty water and the sea-loch where the water is green above the white sand, and purple above tangle.

$\mathrm{Ah}$ ! the purity of the air there, with its scent of peat! How I have longed for it in town, and even in warm South Norway counted on breathing it again, and at every breath thanked heaven for its restorative energy. The morning dive was past expectation - how the Shetland sea makes the blood tingle and the skin glow! And the contrast from the outside keen air, after days buffeting on the North Atlantic or North Sea, to come into the warm stone house, to sit by 
the glowing peats and coal, surrounded by books of travel, illuminated missals and natural history, to read or to listen to my host telling tales of the times of our fathers, told as they told them, without haste and with exquisite inflection and skill in picturing peoples and places at home or abroad.

One family story he told me should be of national, or even international interest, so I must make it a classic. It was in the first days of trains in this country that my host and his brother were coming back to school in Edinburgh from Cloan in Perthshire with their father. The father was considered a splendid traveller, for he could actually sleep in these Early-Victorian carriages! As he lay asleep with a red rug drawn over him-which Haldane says figures largely in his boyish recollections-he and his brother plugged cattle and engine-drivers and various things as they passed, or at the stations, with their catapults, till at Larbert old Haldane awakened and saw the instruments and asked the boys what they were. "Never had such things when I was a boy," he said. They explained to him how to fit a stone into the leather, and he did so and held the catapult out of the window and let fly, and with inexpressible joy the boys watched the stone go hurtling into the centre of the stationmaster's window. Old Haldane promptly pulled the red plaid over his head, and out came the wrathful stationmaster, and the guard, and a boy clerk, who took them to the Haldane carriage. Wrathfully the stationmaster pulled open the door, and met the gaze of the cherubic innocents. Then angrily he pulled the red rug aside and disclosed the stern, judicial features of Haldane senior.

"How dare you, sir, disturb me in this rude manner?" he demanded of the guard he knew so well, and "Och, sir! Save us ! - It's you, Mr Haldane ! A' maist humbly apologise. A' maun hae made a mistake," and he bustled away, angrily elbowing the boy clerk and muttering: "Yon's Mr Haldane, ye fuil, ye gowk, Haldane o' Cloan, yin o' the biggest shareholders o' the Company." "Ye may ca' him what ye like," said the clerk, "but A' saw him let flee yon stane."

As the train proceeded, Haldane père emerged from the red rug again and the three laughed long and loud, and the 
juniors told their father more about catties and what they did with them at school. And this led to talk of fights, and they asked their father if he ever fought at school, and he confessed to having done so and pointed to two metal teeth, mark of an ancient fray or " bicker " between the Edinburgh Academy boys and the boys of the Old Town on the mound. It is at this point that this domestic tale becomes of national interest, for the present Viscount and our Lord Chancellor appears on the scene; he was much the junior of these two elder brothers, and soon after this, when they had all got back to their respective schools, "Campy" and his brother asked Bob, the Benjamin, if he ever had a fight, and jeered at him for being at such a school where they didn't fight-I forget which it was, possibly Henderson's, and he replied that they were taught at school that it was very wrong to fight, and they referred to the two metal teeth of their father, and gentle Bobby went away thinking. A few days later he came home from school with two black eyes, and his poor little nose pointing north by south, and Lispeth, the old family nurse, was nearly broken-hearted. "Oh, wae's me, puir wee lambie, wha's gaun an' made sic a sicht o' ma bonnie wee bairn ?" And he explained. He was top of his class, and "I thought I ought to fight, so I looked at the other boys, and there was one long one, at the bottom of the class, and I just gave him one on the eye-and he licked me." And there were poultices applied to the black eyes-and his nose you have seen-and much pity from Lispeth for her bonnie wee laddie.

So the elder brother, R. C. Haldane, after travelling the wide world o'er, has found the most quiet, most restful spot in Ultima Thule, and the youngest is, we trust, still fighting for universal service, we trust, in London, England.

On this Haldane senior's property we have the land station of our little whaling company, the Alexandra Company, which by our Government is allowed to run two small whaling steamers only, and incidentally to employ many Shetlanders at 23s. a week. More steamers we may not have. Ask herring-fishers why we may not! 


\section{CHAPTER IX}

$\mathrm{P}$ ERHAPS it will be as well for me to hark back here and make some extracts from my last year's whaling $\log$ and sketch-books, for who knows when this St Ebba will fall in with whales; in this way the reader will the sooner be made acquainted with the procedure in "Modern Whaling."

The extracts that follow have appeared in magazines-in The Nineteenth Century, The Scottish Field, andin Chambers's Magazine, and Badminton, but possibly the reader may not have seen them; and I am sure that the illustrations have not yet been submitted to the criticism of the general public.

The first begins one evening in June a year or two ago, when we were fishing sea-trout in the Voe at Lochend, beside our whaling station, putting in the time till our whaler came in from the outer sea.

On the evening of the second day of waiting a fair-haired, rosy-cheeked boy with great grey eyes and a ragged red waistcoat came down from the hill bare-footed and breathless, and said: "She is there!" and went off in astonishment at the unfamiliar silver. Then we got our bag down to the shore and waited for the smoke above the headland which would tell us that our little steam-whaler had been into the Colla Firth station and had left the last captured whale there, had taken coal on board, and was coming out again for the high seas.

Henriksen has heard of our arrival and, as she swings into the bay in front of Haldane's house down comes her pram, and two Norsemen come off in it and take the writer on board.

$\mathrm{Ah}$ ! it is good to feel again the rolling deck, on " the road to freedom and to peace," to the open sea and big hunting, 
and to read in a note from the Works Manager that we have at last to act as harpooneer.

Yell Sound is calm as a mill-pond, with swiftly running tides as we go south and east past the Outer Skerries. We aim at a latitude N.E. of the Shetlands beyond the "fortymile whaling limit" made against British whalers only.

Even with a glassy calm a steam-whaler has a rolling send. She seems to make her own swell to plunge over, but it's a silky, quick, silent motion that, once accustomed to, you never notice; though old seamen are prostrated with it when they first experience it. Round about the islands we see many seals and an endless variety of divers and other seabirds and some herring-hog or springers, a small finner whale (Balænoptera Vaga), and porpoises in great numbers, so we practise swinging and aiming our gun in the bows at them, against the time when we have to fire at the mighty Fin whale (A), Blue whale (B), Seihvale (C), Nord Capper (D), or Sperm(E), ${ }^{1}$ for even Sperm and the Nord Capper we have killed in the last two years off the Shetlands, yet the Nord Capper or Atlantic Right whale, Biscayensis, was supposed to be extinct! and the sperm or cachalot is a warm-water whale and only occasionally is found as far north as the Northern Shetlands, or as far south as the South Shetlands south of Cape Horn.

The modern whale gun or swivel cannon is on the steamer's bow and is swung in any direction by a pistol grip. It weighs about two tons, but it is well balanced when it has the oneand-a-half hundredweight harpoon in it so that a hefty man can swing it fairly easily in any direction. The difficulty for the landsman shooting is, of course, in his sea-legs-you must be absolutely unconscious of them and of the vessel's movement, or of pitch and roll, and the wet of cold, bursting seas that may come over you at any time in the pursuit; but, given good sea-legs and indifference to a wetting, and there is nothing in ordinary circumstances to prevent, say, a fairly quick pistol shot from killing his whale, a certain amount of strength and nerve is required for the final lancing from the pram or small boat, but that is seldom done nowadays, for a second

${ }^{1}$ A. Balænoptera Musculus; B. Balænoptera Sibbaldii ; C. Balænoptera Borealis; D. Balæna Biscayensis; E. Physeter Macrocephalus. 
or third harpoon is usually resorted to, as being more effective and less risky.

At midnight we turn in with regret from the pink light and calm sea, for Henriksen the master, and the writer, have much to talk of about whales in other seas ; but a few hours' sleep we must have if we are to be steady in the morning.

You turn in " all standing" on a whaler, you have no time to dress when the call comes; so much time is saved out north-east. At three A.M. perhaps you tumble out, there is enough daylight to read by all night, but between eleven and twelve, and three o'clock, you are pretty safe to have a nap, for you cannot then see a whale's blast beyond a mile or two.

We are now (five A.M.) going N.E.-a lovely smooth seanothing more idyllic we think than at five in the morning to be steadily pegging away over the silky swell seventy miles north of the Shetlands into the sunrise on a warm morning, watching the circle of horizon for a blow. One man is in the crow's nest on our short foremast, another at the wheel, and you lie your length on the bridge, on the long chest used for the side lights, which of course are never used here, with glass in hand, watching. The gun is ready in the bow, and the harpoon and line are all in order. There is no hurry for a blow, you have to-day, and to-morrow, and the next day before you to hunt in, food and fuel for a week, and the wide sea to roam over in what direction you please, towards whichever cloud castle you choose, and if rough weather comes, you are confident your little ninety-five-foot whaler will ride out anything, if she is not pressed.

It is turning out a beast of a morning for whaling. Oily calm but a lumpy swell, making us crash about, and never a blow in sight; I have been handling gun for practice, an excellent opportunity in this swell from the N.W. crossing the swell from N.E., the gun muzzle yaws a bit and our feet are apt to be insecure on the little platform in the bows, and there is nothing to hold on to but the pistol grip of the gun. We pursue our north-easterly course, then go at forty-five degrees, say ten miles N., then say ten miles N.E. again, a simple way of keeping our position on the chart. Of course 
whenever there is anything like "a blow," we swing about in that direction; rather a charming feeling after the usual experiences of travelling at sea in one dead straight line. It makes you feel as if the ocean really belonged to you, and you are not merely a ticketed passenger sent off by the timetable.

In the forenoon we fall in with three whalers from Olna Firth, the station of the Salvesens of Leith, and all of his had been scouting in different directions, over hundreds of miles, and not one had seen a spout, and yet where we are, there were numerous whales only a few days ago. Like trout, whales seem to be unaccountably on the rise one day, and utterly disappear the next. So we resort to music and painting. Henriksen plays Grieg on the weather-worn melodeon and the artist paints sea studies.

At twelve comes a meal, usually called middag-mad on a Norse whaler, Henriksen calls it tiffen. It is simple enough -a deep soup plate of hasty pudding (flour and water boiled), on this you spread sugar half-an-inch thick, and then half-apacket of cinnamon, on your left you have a mug of tinned milk and water, on your right a spoon, and you buckle to and eat perhaps half-way through or till you feel tired; it is awfully good; then you eat smoked raw herrings in oil from a large tin, black bread, margarine and coffee, such good coffee. I'd defy anyone to be hungry afterwards or ill-content. Dolphins pass us and we pick up a drifting rudder. Henriksen sniffs at its workmanship and says: "Made in Shetland," so I quote the Norse saying: "The family is the worst, as the fox said of the red dog."

However, I suppose we will stay out till we do find whales or finish coal. It almost looks as if whales could stay below and sleep. One day's blank waiting seems a long time from three A. M. to eleven or twelve P.M. We growl together on the bridge, skipper, self, man at wheel and the cook. There is no hard-and-fast distinction of rank on a Norwegian whaler's bridge, and Henriksen counts up our mileage, one hundred and sixty-nine since last night. "We might be having cream and fruit in Bergen," he remarks; we are about half-way across, and we all wish we were there. 
Henriksen says, by way of consolation: "Well, I was once six months whaling for Japs off the Korean coast, and I never saw a fin, and fine weather just like this " ; and I tell him of our being surrounded in the Antarctic with hundreds of whales up to and over a hundred feet in length without sufficiently strong tackle to catch them ; don't we both long for one of these huge Southern fellows in this empty ocean.

At evening meal, or aften-mad, are potatoes, tinned meat and anchovies, bread, butter and coffee, and we feel vexed that we do not have whale steak and onions as we expected. The cook explains that owing to warm weather his last supply went bad, a grievous disappointment, for whale meat is worth travelling far to eat ${ }^{1}$; it is superior to the best beef, in this way, that after eating it you always feel inclined for more. The evening we wiled away by making an invention to kill mackerel, of course keeping a keen watch all the time for a blow. Mackerel shoals appeared in every direction in patches, rippling the smooth sea for miles. Our plan, inside the three-mile limit may sound infernal; a hundred miles out it didn't seem so wicked, especially as we had keen appetites for fresh fish. We filled a quart bottle half full of gunpowder, put a cork and foot of fuse into it, slung a piece of iron under it, lit the fuse and dropped it into a shoal of mackerel, and sheered off. The result ought to have been lots of stunned fish. A little thread of smoke came quietly up through the falling sea-and then-nothing happened!-a faulty fuse, we supposed. We tried a dynamite cartridge and fuse later, but the fish had gone, and of course, it went off ; and gave our little whaler a knock underneath as if with a hammer, then we hove to, and all went asleep, and the Haldane watched alone in the half light of the Northern night for a few hours.

At three A.m. Sunday, we were under steam again, the day very grey and the wind rising slightly from W. by S. "Like to be vind," said a young, blue-eyed Viking with long fair hair and a two-weeks' beard, but I doubted it; youth is apprehensive or too sanguine-age is indifferent. Which is best?

We are heading west again, east to west and back again and north and south, we go in any direction we fancy, but

${ }^{1}$ Far the best whale to eat is the Seihvale Balænoptera Borealis. 


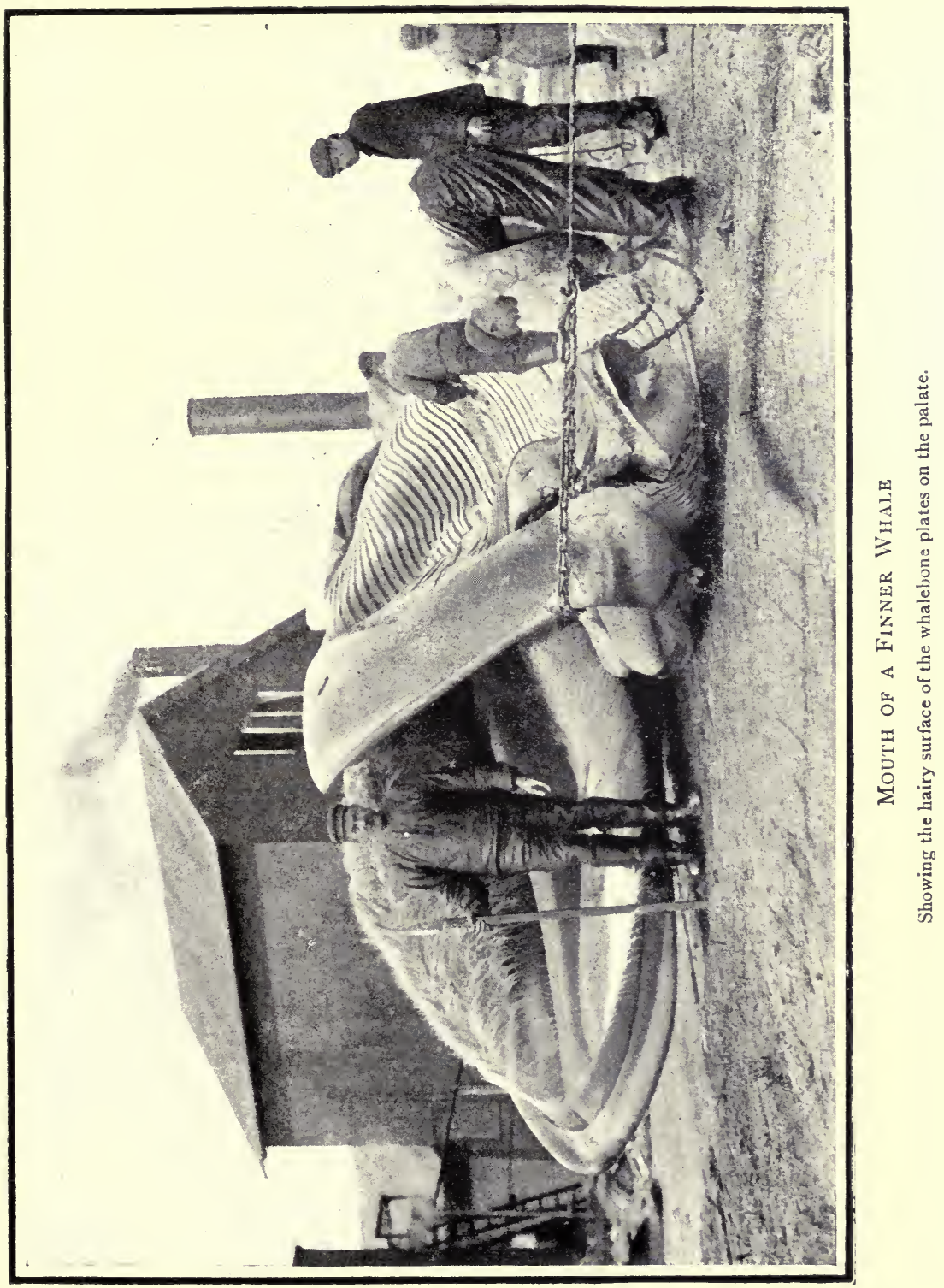





\section{WHALING AND BEAR-HUNTING}

never a whale, so the Sabbath is devoted to the melodeon and painting. We have a book to read but the cloud pictures and their reflections always take our eyes from the print.

So we live on a whaler, in old clothes, seldom changed. I think we rather affect worn, patched clothes. Our cook or steward, a man of means, I have no doubt, in his own country, has a faded blue jersey, the darning of which must have pleasingly occupied many of the few hours of leisure he has on board, and the men, too, have most artistic patches on their clothes. They differ from their superior the skipper in that their coats are torn and darned, and his is torn and not darned. The writer's is neither, but will be shortly, and the crease in the trousers is a memory; it goes soon on a whaler, where you waste no time changing clothes-certainly not oftener than once a week. But, though we are roughly clad, we have Grieg's music, rye bread, and whale meat, luxuries we often have to do without on shore; the blackbread Socialists will have none of it, and the meat for which the Japs, even for the fat, pay twenty-five cents a pound.

The melodeon player's biography would make good MS. $\mathrm{He}$ is young and big, weaned from shore to sea by his skipper father at thirteen; master's certificate at seventeen; then mate on a sailing ship to the Colonies; master and gunner on a Japanese whaler; twenty pounds a month; seven pounds for each whale and all found; large pay in Norway; purchaser of his own island; farm, wife, three children; a sixteen-hand fast trotter, sleighs, guns, rifles ; six months on shore; six at sea; youth and exuberant spirits and as keen about securing a guillemot for the pot as for a four-hundredpound sterling Nord Capper. . . . The day passes and it seems as hopeless as ever, but I find Henriksen knows some useful fo'c'sle language for the relief of feelings; it gives a little lurid colour to the otherwise monotonous soft pigeongrey landscape.

For hours at a time the fascination of watching the horizon for a blow is enough to keep one's mind fully occupied, but at length and at last the writer begins to count painting and reading as of equal interest-a deplorable state of affairs. It is almost hopeless, from a whaling point of view, so we are 
going to give up this ocean north-east of Shetland, and go south-westwards some seventy-five miles till we see the Flugga Lighthouse, thence we will make a new departure and go and have a cast in the North-West Atlantic.

Ah! but I have hopes-there were big finners in families out there last year, at about this time they came up from the south, possibly from even south of the Line. I remember the oldest members were very exclusive, but some of the younger people made our acquaintance. There was one, an island !may I have a shot at it is my prayer, then would there be some real interest in life for us all.

So we practically put in the Sunday without work, only watch and hope, and make a passage ; but the two engineers and two boy stokers work. One of the stokers looked as if he did so hate work this morning-came on deck with his black face disfigured with an expression that meant: "I could kill anyone if I was strong enough!" $\mathrm{He}$ is such a sleeper that Larsen, his master, to waken him, took down the foghorn in the small hours and blared it into his ears. Henriksen in the chart-house where he sleeps, jumped at the sound, and I too, sleeping aft over the rudder, dreamt I heard the sweet note.

It is a curious little family party we are; bit by bit, I begin to know about the individual, gentle, blue-eyed Vikings, about their farms, and boats, at home; for farms and even sheep have a certain interest at sea, when you are not watching for whales.

One of them, a long, young man, with pale eyes and three or four fair hairs on his chin, has such a kind expression, and a stutter! It is the funniest thing in the world, in the beginning or the middle of a chase, if he is at the wheel, to listen to him, as he tackles the speaking tube. He spits hurriedly, then in a sing-song note, he says : "F-f-ulls-s-speed," twists the wheel and spits again, saying some Norse expression for "Tut-tut" or "Oh, bother," and then the same performance at "S-s-saghte" (i.e. Slowly). Finally he gives up stuttering words down the tube and resorts to the engine-room bell for signalling.

I have already touched on the interesting subject of meals 
on a whaler; I have known one begin at five P.M and finish at eleven P.M., the prolongation being the result of frequent dashes from the minute mess-room to the gun platform in bows or to the bridge, in the immediate prospect of getting alongside a whale. To-day we begin our midday meal at the swect end-why, the Norse only know!-prunes and rice, winding up with tinned herrings and coffee. After food we studied Art, did bits of sea from the bridge and pretty faces from fancy, the skipper played on the melodeon, and we exhibited in the chart-room, and each of the unshorn Vikings as he came to the bridge for his trick at the wheel or on one excuse or another came in and looked long and admiringly. Of course I had painted to the gallery-the girls had blue eyes and fair hair, the colours of birch bark, the silvery harmonies of nature beloved by the Norse and the artist.

At three in the afternoon we got sight of the Shetlands and Flugga to the west, and made a new departure to the N.W. We were only three miles south of our dead reckoning; not so bad, after several days lying hove to, and dodging about in all directions, with neither sextant nor chronometer; a chronometer gets knocked out of time in such a small craft with the shock from the gun. Towards night the Haldane's engines slowly stopped in accordance with orders ; which orders our friend the stutterer at the wheel did not know about, and his muttered imprecations on the lazy engineer stopping, as he thought, for a rest, made us all on the bridge, skipper, steward, and two of the crew, laugh till the tears eame! a little goes such a long way at sea in the way of a jest (in fine weather).

So we lash the wheel to windward and roll about just over that scandalous limit line-forty miles $\mathbf{N}$. of Shetlandinside of which any foreigner may whale, but we may not! We have seen nothing for twenty-four hours and the sea is as empty as the Sahara of herring-boats; the crew have three hours' sleep.

Monday, 4th July, three A.M. A most bilious morning, enough to make a seagull ill or upset the hardiest shell-back; the world seems just a bag of hard wind and cold water, squalls, and scraps of rainbow, and tossing seas, with the 
eerie sough in our scanty wire rigging. We bury our bows. For five minutes our faces pour with rain and spray, the next five we dry and shiver in the cold and early sun, and vainly search the horizon for a whale. We think, almost with regret, of warm rooms in town in the South. There is no rest anywhere, aft or forward, or on the bridge, and we plug on northwards, and there's never a blow anywhere in this useless bit of the world. It requires extreme æstheticism to see beauty in such cold water and sky, and hope to see sunshine through these squalls. We peg away in silence; yesterday, we could talk; to-day it is too cold. We bury our hands in our pockets and weep with the sting in our eyes. Yesterday, we discussed, as far as we could, the reason why whales suddenly will not rise; like trout, they do so one day and not the next, but unlike the trout-fisher, who is usually ready with a theory to explain the lethargy of trout, our Norse whaler simply says: "I doan know; der yesterday now gone; vee go vest hoondred twenty mile p'r'aps vec find 'em der."

By midday we are thirty miles beyond the limit and are going west, and the day seems to have regretted its angry rising and is now making amends to us by putting on all its best things. The colour of the water has turned from dull lead to sunny emerald-green with belts of purple, and over it all is a lacework of lavender, the tracery of reflected sky, picked here and there with white sea caps. A jolly exhilarating sea occasionally comes on board, and rollicks sparkling round our deck, full of good intention, and we make it welcome and enjoy it, and let bygones be bygones and pretend to forget it is not always in such a jolly mood.

I knew we would get sun and warmth out N.W. ; there is a space of ocean if you can only find it just between W. and E. that is always sunny and full of whales. I know it, but cannot give exact latitude and longitude; that is why it is so hard to find, but you are sure to strike it in time; so probably we will do so again to-day. We are getting the sun now, we only need the whales, and a little less sea for pleasure and comfort.

The writer and the skipper were discussing the colours of 


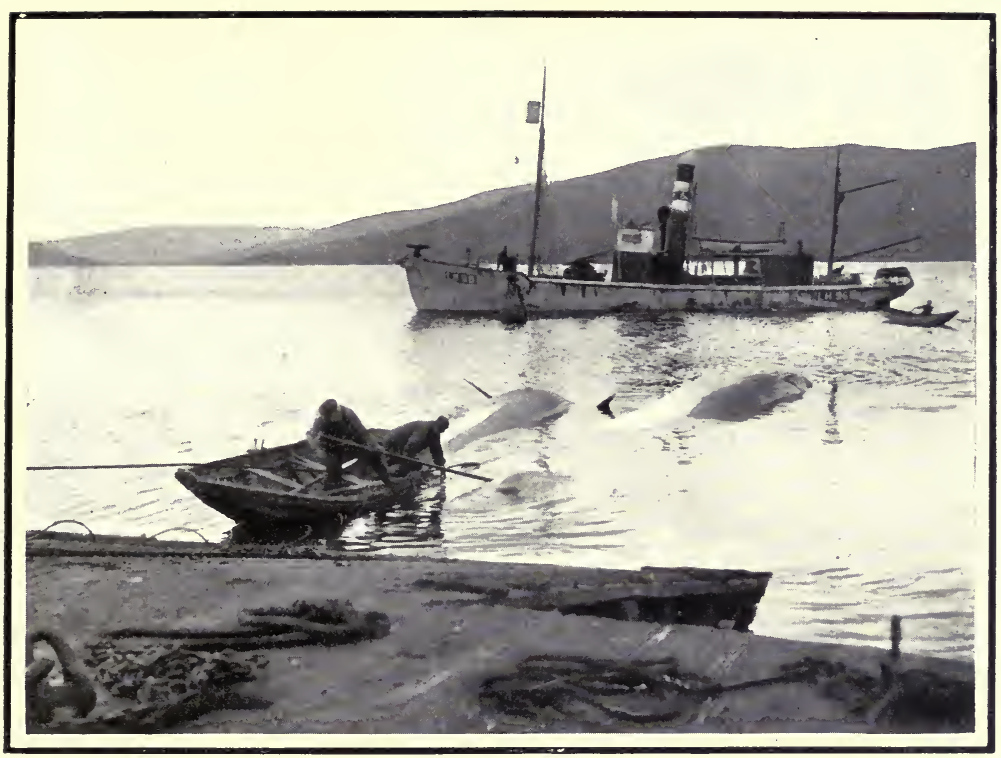

Leaving Our Two Whales at the Station

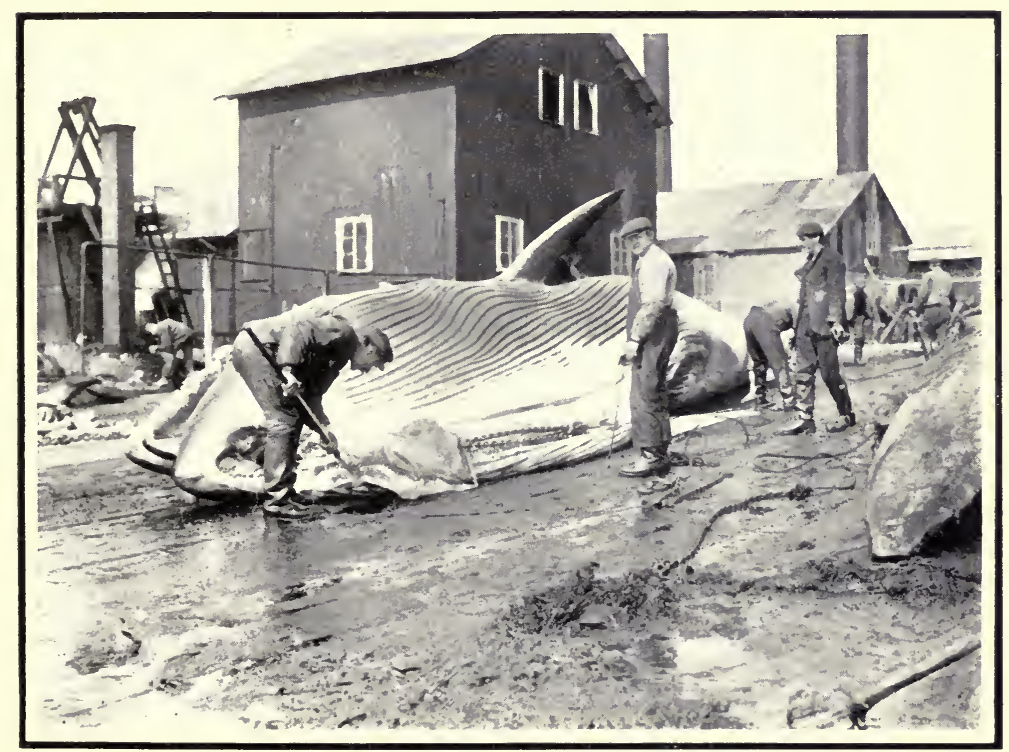

A Finner Whale Being Cut Up

Commencing to cut strips of the blubber with a flensing knife. The blubber is being pulled away as the man cuts by a chain and steam winch. 

the sea; Henriksen, unlike the average whaler, does not despise things æsthetic; on the contrary, he takes delighted interest in Nature's picture-book. As we painted, and discussed how to get this effect, and the other, there came from the crow'snest the welcome cry of " $\mathrm{A}$ blast!" and the response from the bridge: "How far?" We were bowling south with a blustering, following wind, really too rough for whaling, for the sea made us yaw this way and that. However, there was no choice; there was half-a-chance and it was not to be missed. It did not turn out to be a long chase; it was a solitary finner and we swung after his first blow a mile to port and at his third blow were within a quarter of a mile. Then he sounded, and in twenty minutes came up again and blew a twenty-foot blast of steam into the bright windy air. Again we pursued and were nearly in shot at his second blast, and were following him north against the sea with the foam coming splendidly over us at every dive, making one fairly gasp with excitement and cold, but feet and legs held good; they shake a little, we notice, whilst we look on at another gunner. We were all wrong at the third rise; a mile out and very disappointed, then, to our astonishment, three minutes after appeared a blast to leeward, and the huge, plum-coloured shoulders of a leviathan coming right across our course- the same whale or another we could not tell. A turn of the engine then "Saghte" (Slowly), and we surged ahead, rising and falling on the far too big waves. Then a strange and rare sight came; owing to the position of the sun, the light shone right into the banks of waves, and inside one and along it, we obtained a splendid full-length view of the whale under the greeny water looking almost yellow and white. We have only on very few occasions obtained such a complete view of a whale, when looking down on one, but in this case, it was a complete side view. Up we rose in a thirty-foot surge, and the top of his dark shiny head appeared, up rushed the blast, and over went his enormous back. How we wished it was higher out of the water. As we plunged down a wave its back showed at its highest, and we pulled the trigger, aiming almost uphill as we plunged our bows under. It was a longer shot than usual, about 
forty yards and in rougher weather, and the harpoon plunged in at the centre of the target! What a boom and whirl of

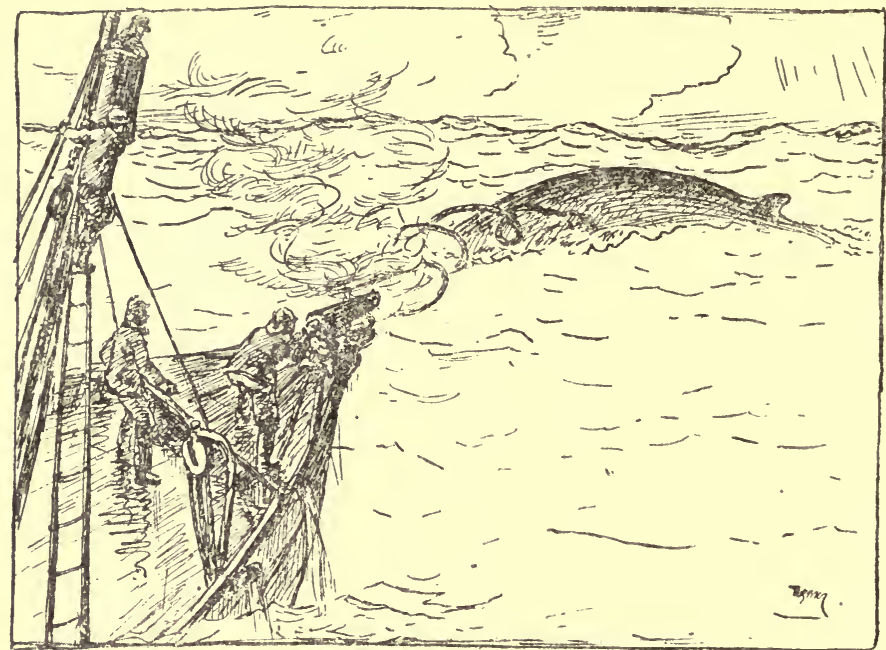

Harpooning a Whale

rope and smoke, and what a glorious moment of suspense and then intense satisfaction when the great line tautened up and began to run-some excuse for a wave of the cap.

But wait ...! What is this ? the line is suddenly slack. There was no miss-what has happened we cannot tell. All we can do is to wind up-we have lost him, somehow or other!

I know men who feel almost relieved at missing a whale, for they say they have had the hunt, which is better than the actual harpooning, and after-play, and so I have heard some salmon-fishers talk, who say they hook their salmon, then hand the rod to their gillic. Not so with the writer; one part of whaling or fishing is as good as the other to me, and to harpoon your whale and lose it is too distressing for words.

At last the harpoon comes on board-the flanges have never opened! - there is flesh on them, and a foot up the shaft-two and a half feet it had entered, and yet came out ! possibly the marlin round the flanges was too strong to allow of them spreading. Possibly the explosive point made too 
great a hole and allowed the flashes to miss their anchoring hold. It was bad luck for us and for the whale. Our leviathan disappeared and we wound up, very melancholy. ${ }^{1}$

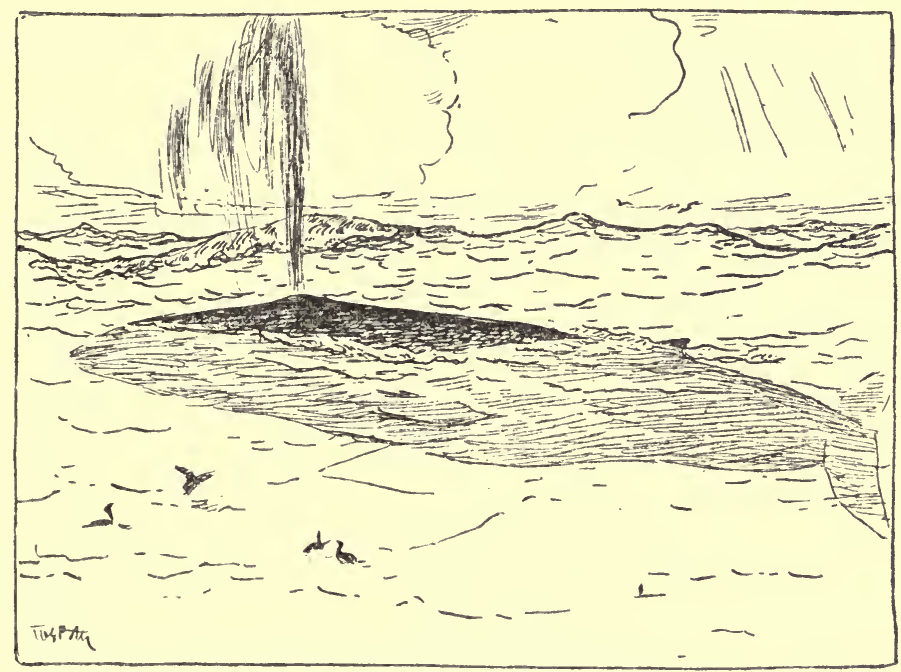

View of Whale under Water

A slight consolation was that a neighbouring whaler was seen to fire at another whale; we heard the boom and saw the smoke, and nothing more-she had made a clean miss! probably owing to the roughness of the sea.

1 We picked up a dead whale two days later and we hope it was the whale we lost. 


\section{CHAPTER XI}

HE solitary finner we hunted disappeared, and we hunted for hours towards heavy purple clouds in

1 the S.W., and the sea seemed deserted as before, till towards six o'clock we saw a blow, and soon after saw the crow's nest of a whaler above the horizon ; she appeared to be working to and fro as if hunting a whale.

In half-an-hour we were amongst great large whales! and began the most spectacular whale-hunt we have ever seen. For two and a half days we had hunted blank, lifeless ocean, then, without rhyme or reason, it was brimming with life! An indigo bank of cloud there was for background, a complete vivid rainbow against that-beneath it the swelling seas, dark green with purple lights and white foam, with here and there whales' white blasts catching the western sun from a score or fifty enormous finners. In every direction were dolphins with yellow and white stripes, and porpoises spurting water up like cannon shots as they dived; overhead were petrels and dark skuas. The whales' plum-coloured backs caught the western light and reflected the sky on their upper surface in tints of lavender as they rose, glittering and powerful, in green and white foaming water, thousands of pounds sterling, and millions of horse-power, in groups of three or four surging along beside each other, east and west, sending up mighty jets of steam, to be carried away in the wind.

As we went in chase of a group of these we saw the other whaler was fast to a whale, over which she apparently had no control.

The whales were feeding, but travelling so fast that we could not come up with them, so we cut across their course, and dozens of times we thought we were going to get our chance. Then other bigger whales crossed, and we gave up the first lot and went plunging after the others, throwing up grand showers of foam over our bows and oilskins. But cold and 


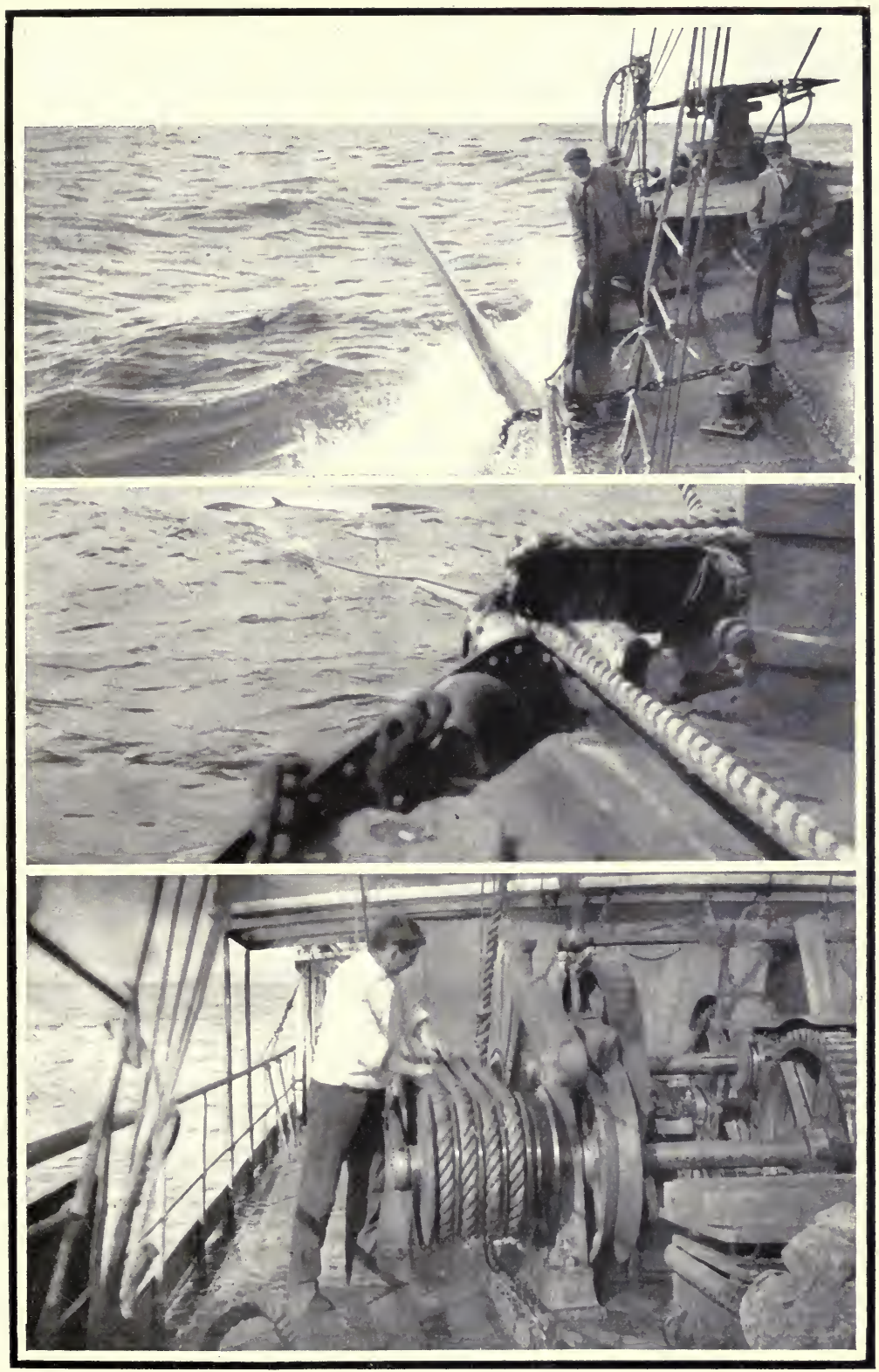

Towing a Whale

The top plate shows a fluke, that is, one half of a whale's tail, fastened by a chain to the bows. This is cut away to prevent resistance to the water. Note the gun and harpoon on the bows.

The middle plate shows two $5^{\frac{1}{2}}$ lines attached to a whale.

The bottom plate shows the double-barrelled winch and line and grooved wheel on which the hard wood brake acts. 
$\therefore \cdots$ 
wet you do not think of, with seventy or eighty tons charging in front of you and the chance of getting in the harpoon any moment. For several hours we chased in this wonderful piece of sea, so brimful of life, but the whales dodged about at a most unusual rate; possibly their rapidity of motion was caused by the host of dolphins and porpoises that leapt alongside them and crossed their course; and for all these hours we could occasionally descry our neighbour through the rain showers and failing light, still in tow of her prey. Not till about nine o'clock did she fire a second gun and we hoped she had got in another harpoon to finish her prolonged fight.

Often we were close to a whale but not in such a position as to be able to swing the gun towards it. For some time a huge fellow surged close alongside within one or two feet of our starboard beam and never touched us. I think they must have a sense by which they can judge their distance from a vessel's or boat's side or ice : one can hardly believe they judge the distance by the eye alone.

At about ten o'clock our real chance came-we crashed down from a high sea almost on top of a whale as it rose unexpectedly, but it was too close, we could not depress the gun enough to get the foresight on, but the next rise, the moment after its blast we were high in air and let drive as we came down and were fast and sure.

I do not know how to describe the grand rush of a huge whale or that fractional pause of uncertainty after the boom and smoke and flame and the whirl of great rope. It is heartstopping, almost solemn. You watch the seething black boil where the whale has gone down, with small flecks of scarlet in it, and the great cable fading down into the depths, and the gun-wads smoking on the water. Then off goes the cable to right or left! Sixty to seventy miles an hour, cutting the water into foam, and we swing into the course of the whale. Before going fairly in tow on this occasion, an unusual thing happened. The whale's huge head, immediately after it sounded, suddenly shot up twenty yards in front of our bows, twenty feet in the air, and 
went as quickly down. We were glad it had not touched us, or we would have had quick work to get into our boat, and our little steamer would have made a deep-sea sounding.

About three hundred and sixty fathoms ran out before we saw further sign; running over the two ringing barrels of our strong steam winch, five times round each barrel with the brake such as you see on a railway engine wheel hard down and burning; then foam appeared a quarter of a mile in front, and our whale's flippers, then the mighty flukes of its enormous tail, slowly threshing the sea into white. To right and left it travelled, towing us ahead whilst our engine reversed at eight knots but not for long. We managed to wind up some line and got the gun loaded again, thinking it might take another harpoon to stop it, for lancing from the small boat in such a heavy sea would have been too dangerous, even if possible.

It was a short fight. At ten-thirty we harpooned it; at eleven-thirty we had it alongside; a weight and line thrown over its tail; took out a heavy chain which was shackled round above the tail and hauled by the steam winch to our port bow beside the anchor davit, then with the huge body with its lovely white corded underside above water surging alongside we steamed ahead. It seemed to be about seventy feet and would probably weigh about seventy tons, and it made us lie well over to port. To float it a little higher out of the water, we drove a pointed tube with holes in its side through the white kid skin, and blew in air and steam. We began our day's hunting at three A.M. and wound up and started home at eleven-twenty P.M. We have to go, without waiting for another whale, for we fear the station hands may be standing idle and we have ninety miles to cover at not much more than six miles an hour, for the dead whale alongside stops our speed.

No two whale hunts are alike; one trip you come home with a "clean ship" and empty bunkers, the next you get two or even three whales in a couple of days and come home at once and give all hands, Shetlanders and Norsemen on shore, work for night and 
day. ${ }^{1}$ Here we consider three in a day for one steamer a big catch.

Another Government regulation restricts our number of steamers and we are allowed to have only two, so that often it happens, owing to our only having two steamers and both of them being out hunting, our station hands stand idle, but the restrictions put on this new industry by official "experts" at home and in our colonies, who have only recently learned that this whaling exists, make too tearful a subject to insist on here.

During a summer season, our Shetland station, with only two steamers, may catch from seventy to one hundred. There are any number of whales, but they are becoming every year more wary. Needless to say that a whale, if it is frightened, cannot be approached. The whole of the whale's body is used. The best of the meat is sent to Copenhagen, bought by Danish butchers at the stations for 18s. a barrel, sold at Copenhagen as a delicacy at $£ 9$ a barrel. It is very good to eat-between beef and veal, but rather better than either. The Japanese pay 25 cents a pound for it, but we use it for fertilising fields. The oil extracted from the blubber, meat and bone, sells now at about $£ 4$ a barrel; six barrels equal, roughly, a ton $(2240 \mathrm{lb}$.). But the value of whale oil is increasing owing to the invention of a "hardening" process by which the oil is turned into white tasteless edible fat excellent for cooking purposes.

The Right Atlantic whale (Biscayensis), of which we get one or two in the year, is worth $£ 300$ to $£ 400$, owing to its having good whalebone. What we usually catch, "seihvale," and "finners," have only a little bone in their jaws, worth about $£ 30$ per ton. The Greenland Right whale that used to be fished had sometimes a ton of it, which a few years ago was worth from $£ 2000$ to $£ 3000$. The prices fluctuate considerably. When this modern whaling began oil went down $£ 10$ a ton; now, even though the production is enormously increased, its value is $£ 24$ per ton, and will rise in a year or two very much.

1 In the South Shetlands Captain Sorrensen, referred to previously, killed ten whales in one day, one was ninety feet in length, and probably weighed ninety tons. 


\section{WHALING AND BEAR-HUNTING}

In the north the largest whale we have killed was seventyfive feet in length. But in the south, in the Antarctic regions, we have fircd into whales well over one hundred feet in length, and have heard from reliable observers of whales killed and measured up to one hundred and twenty feet.

To get the full value out of a whale it must be taken to a station on shore or to a floating factory. After the blubber is removed thirty per cent. more oil is obtained from the carcass by cooking the meat and bone in huge tanks. This meat oil is twenty per cent. less in value than the blubber oil.

The residue of bone and meat is ground into guano, which fetches about $\mathfrak{E} 7$ per ton. This meat oil and guano together give an addition of more than fifty per cent. to the value of the blubber alone. This guano is much used in America for exhausted cotton soils, and I have been told that it is beginning to be used for rubber estates.

Before writing more about the cruise of the St Ebba, I may be allowed to insert here another chapter of notes on modern whaling made on board another whaler in these same seas-that is, to the north, east and west of the Shetlands. 


\section{CHAPTER XI}

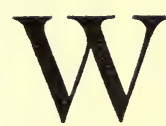

HALING has its seamy side. We met it outside the loch going up west of Shetland-the wind had almost dropped, but the cross sea it left was as if several Mulls of Cantire had been rolled together, and neither our little whaler nor its crew liked it a bit. Rocky capes and islands were blurred in mist and spouting foam, and sometimes obscured by passing rain and hail showers. About eight or nine, morning, we were off Flugga, the most northerly point of Britain's possessions, and the weather was simply beastly; by two in the afternoon, we were about sixty miles north-east, in an intensely blue sea, with immense silky rollers, it might have been in the N.E. Trades. It was just what I expected; thirty to forty miles north of the islands you strike sun and clear sky-we always do, then go west fifty miles and you come up against a curtain of rain.

At three-five we are sloping along half-speed north-easterly over a splendid silky swell, all our eyes sweeping the horizon. The boy beside me at the wheel is the first to spot a blow, to which we promptly swing our whaler, and immediately after, on the horizon, we discover the faintest possible suggestion of a blow, a minute cloud hardly enough to swear by, as big as the tip of a child's little finger. It fades away and we are sure it is the blow of some kind of whale, and the boy rings up the engine-room and, grinning, shouts down the tube: "Megat Stor Nord Capper, full speed!" This to make the stokers lay on, for a Nord Capper means $£ 1$ apiece bounty money to each of our crew of ten men.

At three-ten we begin the hunt; we go seven miles towards the first blow, when there is a shout from the look-out in the crow's nest, and we find big spouts within a mile from our left. So the skipper goes forward to his beloved rusted swivel gun or cannon, in his weathered green jacket, a picturesque figure against the immense blue silky sunny swell. 
Five minutes the whale stays down, then comes up to starboard. "How many were there ?" says Jensen to the look-out in the crow's nest. "Two big and a calf." Eight minutes they stay down and appear half-a-mile to starboard; there is the lovely silence of a sailing-ship as we wait with the engines stopped, studying fleecy clouds and the silky blue stripe our track has left on the swell. It is this rapid contrast that gives the charm to whaling-this morning, in hail and black-eyed sea, a blurred sea and landscape of beaten cliffs and capes; this afternoon a wide horizon, and not a ship in sight, the colour and width of it! But here he is ! He came up half-a-mile to port-appeared two or three times, at a few seconds' interval, then "tailed up," that slow, farewell turn over of the after part of the body as it goes down for a deep dive; and we follow its general direction. In ten minutes he appears a mile to N.W. It is four o'clock, the air S.W. and cold, and bright enough to be N.E.

"Saghte!" (Norse for softly, slowly), he ought to be up soon. . . 4.3 P.M. There he is half-a-mile to east-we hear the blast. These North-Altantic whales don't make half such a resonant loud blast as the Antarctic whales . . a another whale blowing to E. by S. . . Four-twelve. Within two hundred yards, a little to port-we follow, a stern chase-note blue sky reflected on wet plum-coloured back . . . within fifty yards when he made his last dive, Jensen had the gun swung... separate whale appears to the right-very large . . . nearly fired. Four-twenty. Behind, to port, we swing round-we are lacing the rippling swell with blue silky bands-" Lord!" there it is ! at the second rise under our bow-BANG !

A splendid shot!-away goes the line at seventy miles the hour and we are hauled quickly round, and are taken in tow eight miles an hour and the engines going eight miles astern, if that is not exhilarating!

Jensen wipes his nose on red handkerchief-the cook and engineer are at the winch brakes-there is a thin furrow of Union Jack colours, red blood, white foam in the blue of ocean-and the line still whirling out at intervals. We "fish 
fine," the casting line is sixty fathoms, the rope four and a half inches in circumference, the finest Italian hemp procurable, with a backing of two thousand one hundred and sixty-six feet, five and half inches rope to port, and the same to starboard, a total of eight thousand six hundred and twenty feet. The line passes five times round the two barrels of a sixty-five-horse-power winch. It is "fine tackle" compared to the seventy or eighty ton fighting finner that we are playing. . . 4.25 - not much line out, only about one thousand five hundred feet-now we go more slowly in tow.-It was a well-placed shot . . . a few Mother Carey chickens come and some fulmar petrels, later a solan goose! - there is a little blood now in its feeble blast, it thrashes with its tail-more line going out—we go astern to drown it. The nose appears, exactly the colour of a salmon at a distance -it turns over. 4.33-White ribbed underside up-now it is dead and it sinks. The line is rove over large iron snatch block ${ }^{1}$ up the mast and the steam winch begins to turn slowly, raising the whale from the depths; a slow, steady, funereal clank; a great chain is manœuvred round the tail and it is hauled up to the side of the bow by the winch; getting the tail chained up to the bow is a complicated, heavy bit of seaman's work. A magnificent and beautiful thing is the tail in colour and form; so wide and big and yet so delicate in design and finish and plum-like colour and so immensely strong. The body swings alongside, the head reaches our stern quarters, the line is cut clear of the harpoons in its body. 4.55 -Two hours after we first sighted the whale, a quick hunt, play, and kill. 5.3-Blowing it up and off for second whale.

Blowing up, as already described, is putting a hollow lance into whale and blowing through it air and steam, which makes the body slightly more buoyant and more easy to tow.

5.30-Sight another whale. Meantime Jensen has been

1 This snatch block hangs on a wire rope that passes over a sheaf and leads down to the hold, where it is attached to an enormously strong steel spiral spring. This makes a give-and-take action when hauling up the dead whale from the depths to counteract the jar on line and donkey-engine that comes from the rise and fall of the steamer on the sea. 
cleaning out the whale gun on the bows with tow and cleaning rod and the charge is put in, and the india-rubber wad driven home on top of three hundred and eighty-five grammes of black powder. The second line from the port side of the hold is made ready, and a new harpoon, one and a half hundredweights, slung from the hold. The line is spliced to the twisted wire grummet or ring that travels in a slot in the shaft of the harpoon, which is rammed into the gun so that line and ring hang from the shaft at the muzzle of the gun. Getting this done and putting chains and ropes in order takes time and a considerable amount of work for five men, and meanwhile we on the bridge are conscious, as we roll, of occasional whiffs from the galley of roast whale steak and onions. For merit I place caribou meat first, whale and black bear about equal, in second place, and beef third.

Five-forty-five. We have screwed on the explosive point to the harpoon (over the time fuse), swung round the gun, and are off in pursuit of the whale we sighted at five-thirty. By six-thirty he has appeared several times, made two or three handsome blasts and gone down "tail up," and we followed, as we thought, in the direction he took, but he always appeared right off our track. I use the term "tail up" not quite accurately here; the expression really means the whole tail going into air as the whale goes down for a long dive. In the case of these northern finners it is generally only the part of the back next to the tail that is raised, not the flukes, and this rising tells you the whale intends to go down deep for twenty minutes or half-an-hour. "A wrong vone," the engineer says_-"he be chased before." You see the engineer, when his mate is below, joins in the sport of watching, ahead, to port, to starboard and astern, and works the winch when we are playing the fish; always there is work for all, and little enough time for meals, if any.

Whilst we roll about in the swell waiting for the leviathan to make our closer acquaintance, I may relate some of the thrilling dangers with which the track of the modern whaler is beset. Novel, unfamiliar dangers must always make interesting reading when people are tired of hearing 


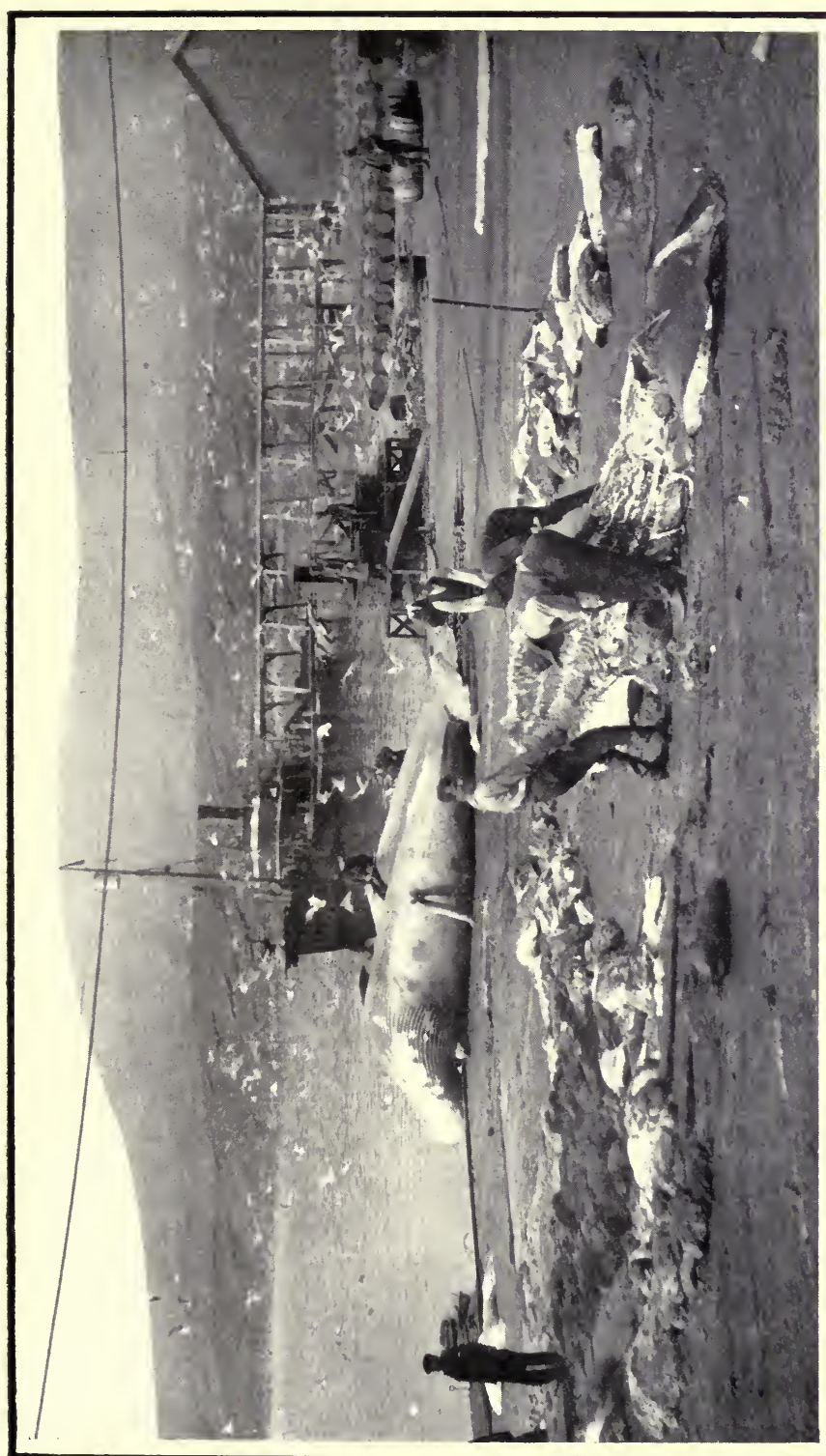

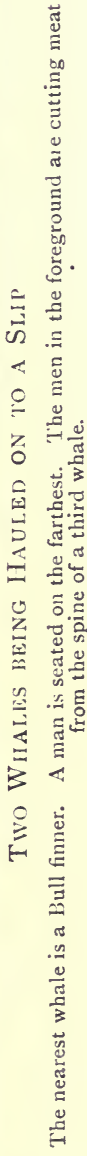



of the risks we all run at any crossing as pedestrians or motorists.

Off Norway, several steam-whalers have had sea-water and daylight let into them by careless whales, and a whale here, some years ago, when the industry was new, took offence at being fired at, and flew at the innocent little steamer (seventy tons solid life and energy against a ninetyfive-foot boat) with jaws wide open and generally chewed-up rails and superstructures, so the owners hardly knew it when it came back to the station. But whales are not in the habit of behaving like this. I did myself, however, experience a mild charge last year; possibly the charge was unintentional, but certainly the whale came straight at our starboard bow, and had we not been quick enough to swing and depress the gun's muzzle and shoot at six yards, something might have happened; as it was the whale came on and struck a dead whale we had alongside, and with its impetus it gave our little ship a considerable dunt in the ribs. "If" it had not been hit and "if" it had struck us a little harder, say twice, we would have had to row home a hundred miles in the boats, which would have been rather a come-down from steaming the wide seas o'er, on our up-to-date little whaler, the Haldane of Colla Firth.

"If" another whale a few nights ago had pulled a little harder, when it suddenly changed from towing us forward to towing us astern, we might have been quite upset, whereas we were only half-seas over. But alas, there was a really very sad and dreadful experience here, two years ago. Captain Torp, a fine man and a good gunner, fired at a whale and the harpoon ricochetted, and three hundred and eighty-five grammes driving a one-and-a-half-hundredweight harpoon burst the five-inch cable, and the inside end came back and wound round him and broke him unspeakably from head to foot, and yet he lived two days, and fourteen ounces of chloroform had little effect.

Then, too, one sometimes gets sunk whilst whaling. Casperg, a master in Ronas Voe, our next-door station, had that experience-went down in his cabin with pipe and tobacco pouch in hand, felt himself kicking the rock with his 
sea-boots under the kelp before he had time to strike a light. He came up all right, but four of his crew stayed down; that was recently. And my friend Sorrensen, engineer of the Haldane, told me comfortingly last year, as we chatted in the warm engine-room one dismal, dark, rough night, when we were trying to find land, that on his last whaling trip to Iceland, in making land in a gale of snow and wind, " on a night like this," he observed a large rock suddenly protrude itself through his engine-room floor, which finished his trip for that year. "Yes, yes, two tree skip do so," he said.

The wonder really is that more accidents are not met with. The whale's head is such a weight of bone; the pointed mass on the upper jaw or beak meeting the huge bent bones of the lower make a most formidable ram.

Another close shave there was the other day. Atried to lance a whale in its death-struggle from the little steamer's bows. We have tried this ourselves with and without success. On this occasion the whale raised its huge flipper, swung it across the gun at the bow, which was loaded with the harpoon in it, and its muzzle was thrown round so heavily that the harpoon was shot out on deck and the shell exploded. No one was hurt, but A-'s oilskin coat had holes torn in it between his legs-and so on. . . .

By eight P.M. we had eaten our whale steak (meals are at any hour or no hour when you are whaling), discussed the latest type of whaler, Captain Larsen's three-gun boat, and had given up that wily old dodger of a finner, and now we peg away over the blue sea to the N.E. The sun swings round with us to dip quite near the north, whilst we wait and rest until it comes up again in a few hours to form our gallery. True, we have another companion beside the few petrels. The Busta, our sister ship, is in the offing. She also has a whale alongside; we can make it out with the glasses as she rises over a blue surge; and as I write, far to the west I descry an almost invisible smoke, which $I$ hope is a boat of our Alexandra Company, the Queen, or the Haldane.

At nine-thirty the sun slants below the horizon and the colour display begins toning down to soft, warm light in the 
north and violet in the south and west. Itis very still, the only sound the surge of the water over the white-ribbed flounces of our whale's underside as it tows alongside. We speak little; there is the skipper, and the man at the wheel, on the bridge, and one above us in the crow's nest; the rest are sleeping below. It is the romantic, beautiful time at sea, formality goes, we talk a little of home and families we have, or may have, and the night, as it were, just droops her golden eyes, and in a very little while raises them on another day, blue and fresh as ever, and we begin another day's hunting, to get, if we can, one more whale to tow to our harbour in the south, there to provide work and pay for Shetlanders and Norwegians, food for Danes and ourselves, and fertilisers for

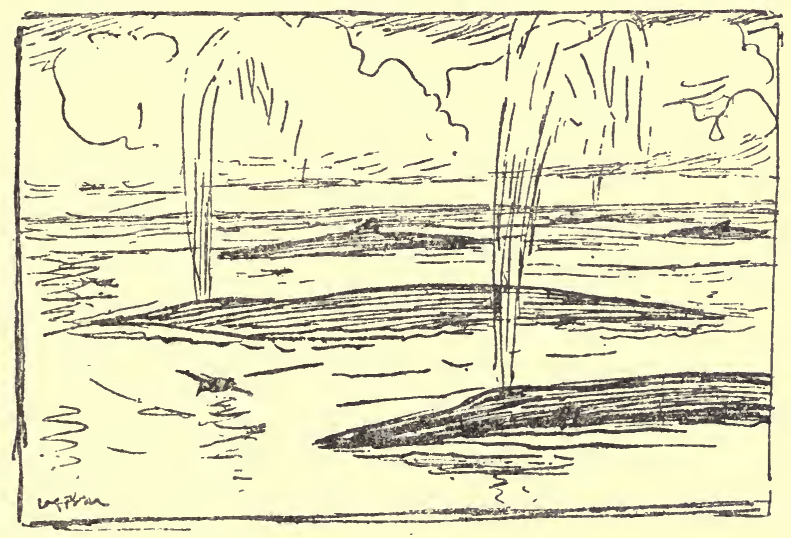

farmers' crops and cattle, each of which subjects could not be treated of in less than a page of these notes for itself. But one word I may be allowed here for readers who are interested in fertilisers for vegetables, and cattle foods. For both these purposes the cooked and ground-down whale meat and bone is invaluable, and it costs about one-sixth the price of ordinary fertilisers-but beware, don't use it for the latter purpose without digging it into the soil. The gardener of my friend, C. A. Hamilton of Dunmore, Stirlingshire, did so-put it on the top of the soil in a vinery, and was " maist astonished." "Ma gosh, Maister Hamilton," he said, "you'd hae thocht I'd plaunted pussey cawts!" it was so mouldy. The same worthy used it properly for turnips, dug 
it in, and exhibited the result at the local show, and was disqualified! The judge said: "Mon, it's turnips is the exheebut-yon's no turnips-wha ever saw neips like thatthey're faur ower big."

A cool, sunny morning, with rolling glassy grey swell and warmer. We are in tow of a large finner; we began to hunt a herd (pod is the old name, it means a family party) at five-

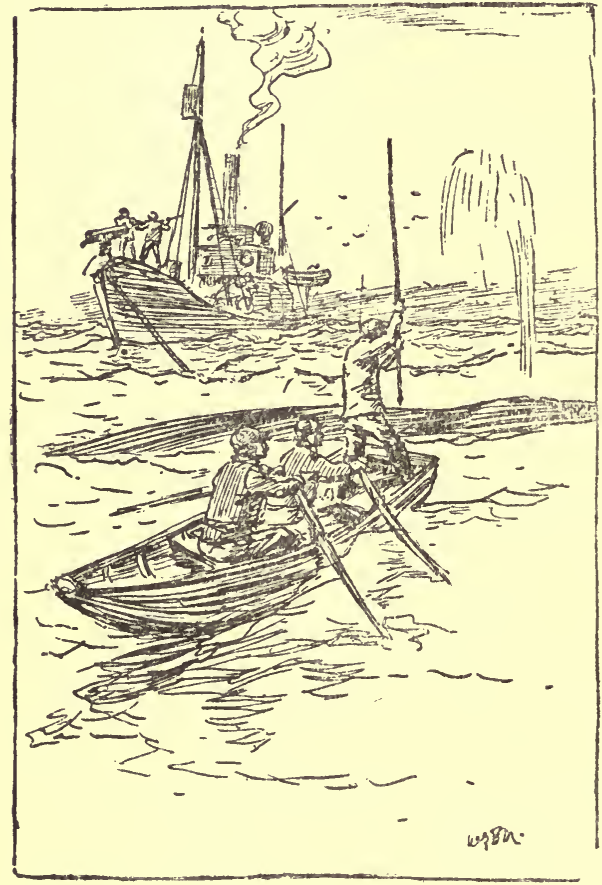

thirty. It has taken five hundred yards out with several rapid rushes of forty to fifty miles an hour, and there is a smell of the burning wood of the breaks; it is very quiet, Jensen has come up beside me at the wheel. I noticed after the shot he again rubbed his nose with the red handkerchief, a little nervous, colourful touch. The whale blows occasionally and turns the swell into white and red; it looks as if we must lance it from the

small boat, or get another harpoon in. It was a most interesting chase; five monsters blowing half-a-mile apart seemed quite a crowd. We got in between two, feeding, and after an hour's hunt altogether one rose a few yards to starboard. Jensen refused it, coolly waiting for the bigger one behind to come up in front, to the left, and mercifully it did, slowly; you could see down its blow hole, then its great back came out, and into, I think, its last ribs the harpoon went, and at the wheel we were all in smoke and 
tow. The smoke cleared and the wads lay in the swelling vortex the monster left, and then the line rushed!

Who can describe the heart-stopping thrill as the monster breaks the surface within shot, only perhaps the dry-fly man, he must experience exactly the same in a minute degree.

But this whale will not die, we must lance it; an eighteenfoot spear is the lance-half iron, half wood. The pram is swung out-we are dropped half on top of our dead whale and slide off somehow. Jensen is handed the lance and away we go, double sculls. Over the glassy rollers we go at a good pace, the whale is six hundred yards away or more and wandering from left to right, and ahead, in the deep swell, it seems as if it would be a long business to get into reach. We back the stern in and Jensen makes a great lunge and the spear goes in five feet and is twisted out of his hand and the vast body rolls over, the tail rises up and up and comes down in a sea of foam. We pull clear back in again at next rise and draw the spear all bent, straighten it, and one more thrust finishes the business and the whale spouts red and dies.

It is a quarter to eight when we finally get the tail up to our port bow and go off easterly; we must be seventy miles N.E. off the Shetland Isles.

Whales seem to be such good beasts, and have such kind brown eyes-nothing of the fish in them, and their colouring is that of all the sea; their backs are grey-black to dovecolour, reflecting the blue of the sky, and the white of their underside is like the white of a kid glove with the faintest pink beneath, so white it makes the sea-foam look grey as it washes across it to and fro, and the white changes to emeraldgreen in the depths to the blue-green of an iceberg's foot. It is strange that this skin should be so extremely delicate in such a large animal; it is too thin to be used as leather.

Our first whale was fifty-four feet, say fifty tons, equal to twenty-five to thirty barrels of oil. Second whale, seventy feet, say forty barrels of oil.

The second whale was a bull "fish," according to S. Johnson of Fleet Street, and the dark colouring came farther over the white corduroy waistcoat than in the female. It is curious how the grey colour blends into the white exactly as 
if it were drawn with a lead pencil on ivory in perfect imitation of hair ; from a few yards you think it is hair, for its formation so resembles the lie of hair on other mammals. I have never heard of this having been observed by naturalists. I am sure a Darwin might make endless deductions from it, coupled with the belief of the old neolithic Indians of Newfoundland that the caribou had gradually changed into whales. The colour of the caribou is quite like the colour of these Seihvale. But we must keep off speculations on the origin of species, and these marks in particular, and the whale's pedigree, opinions, and domestic life. It is such a large subject, though fascinating. Many authentic and startlingly new facts have been gathered since this modern whaling began. For example, a whale was killed last year "wid six leetle children in it." This will rather astonish naturalists-it horrified a Shetland lady in whose hearing a polite Norseman made the relation-but that there were six embryos is a fact I vouch for. I hope some naturalist of means will some day charter a vessel and suitable observers to make a few years' study of the subject round the world. H.S.H. the Prince of Monaco has set the example, particularly in regard to the study of the sperm whale.

It was grey all day, grey sky reflected in lavender-grey water, the surface hardly indicated till an endless shoal of dolphins came out from the shadow of a cloud in the east. They were pretty enough to watch, but we had little time for two finners led us miles here and there over the ocean, but eluded us ever; we had little chance of circumventing them by reason of our two whales in tow. We gave them up and went after spouts like cannon shots against the dark rain-cloud to the east; and this time cleared ourselves of our bag; slipped the heavy chains, fastened a buoy with a tall flag to the two bodies and left them in charge of the Molly Mawks or Fulmar Petrels. But the family of finners we pursued were very wide awake, and though we pursued them for weary hours we never got quite within shot, though dozens of times we whispered to ourselves "A certain shot!" So with more trouble we took our two whales in tow again, and left the gulls lamenting, for already they had begun to pick away 
the delicate white skin. Then we " up sticked" and steered away south-west to this sunny part of the sea, and dozed comfortably as we went, our best speed about six knots, for home.

A fisherman is not to be pitied coming home with seventy tons to port and sixty to starboard, enjoying the sense of comfort and well-being that comes after the first hardening days at sea, enjoying the pure air and the scent of roasting coffee. We do ourselves well on our Norwegian boats this year; at least the coffee is good. As we imbibe it and think our sport is over, we come into warmer weather, a froth of soft white and grey clouds reflected in the swell, two whalers on the horizon and finners in sight. So it's all alive-o! Off with the guns' coverings-we may have a third whale to show the girls on shore-(if there were any!). And we chased these too in the silky silence of that space of sea and air and reflections of fairy lands of softest, most pearly cumulous clouds with only a spot of frosted blue overhead to give force to the faintest yellow, the only sound, the soft thrum of our subdued screw beat and the occasional surge as we crushed down on the glassy swell, and every now and then the great deep, deep sigh of the seventy-ton finners rising in front, alas always just out of reach. One of the whales bore a scar where we think a harpoon had glanced off. The Fritjiof, a neighbour whaler, also occupied this ocean chamber a few miles off and quietly went about in tow of a whale; we saw her fire one shot and noted the colour of the smoke, blue against her hull fading to rusty brown across the sky. She had four lines into the beast when we called on her later, and chatted across the swell to the harpooneer.

Now we have again picked up our prey of dead whales and are toddling home five to six miles an hour at full steam, and ought to be in by dinner-time to-morrow, Wednesday-that is, twelve o'clock.

Wednesday morning, it is, it must be! But it seems months since Wednesday last week. Yesterday seemed a week, with its endless gallery of magnificent sky and sea pictures. Now there is time for a shave and a wash in the sun on the top of the engine-house. What intense luxury! 
What joy to sit and shave and be unconscious of the roll, how superior we feel compared to the townsmen who left Leith a week ago. There's the rush and sound of many waters over our whales on either side, the largest a little less than our own length. All hands have an easy time. It takes two watches (eight hours each) down the Shetland shore to our station, and no whales about. Of course the land is clouded, and we regret that sunny chamber to the $\mathbf{N}$. and E. of Shetland. I speak to Jensen as we pass the western cliffs and he verifies my experience; to the N.W. you come against dark hangings of rain, N.E. you are in sun, back to land and you are in clouds again. It is no wonder that sunny, crystalline stretch of sea a hundred miles north of Flugga Light calls to one in town to go a-whaling. 


\section{CHAPTER XII}

\section{$\mathrm{H}$}

AVING put down these recent experiences of modern whaling, which, though not exciting, may at least be instructive, let us return to follow the fortunes of our patient whalers on the St Ebba.

It is September now, and a Wednesday, and early and clear and cold, with no gale, with just a ripple down Lerwick Bay; one or two people are lighting their peat fires and the scent comes off to us on the pure, almost wintry air, and we hoist the Union Jack astern though no one may see it, and let steam into the steam donkey-engine, and up comes the port anchor, then the starboard and there is a pause and a bell rings for stand-by, then half-speed and clash goes the air pressure; then full speed, and the motor settles down to its steady musical beat and hum. We are becoming more easy in our minds now about our air compressor starting the engine, but have not quite forgotten that failure down south-west of Norway, in the heavy weather, and the subsequent twenty-four hours of hand-pumping for air pressure to start the engine.

Now we swing round and head south and east out of Lerwick Bay, past the Bressay Light on our left, and then turn northwards towards Whalsey and the Outer Skerries, making for Yell Sound and the west of Shetland for whales, finners, rorquals or big cetaceans of any kind. I found on my visit to the west coast of Shetland on Sunday, to our whaling station there, that our steam-whalers had left for Norway a week previously. Owing to the rough weather they said the season was over; but they left word that there were still whales about the coast as close as five miles. Now we have lovely weather to-day, though so cold it feels as if we were at the start of the spring fishing rather than arriving at the end of the season. It will be rather rich if we capture a few whales when the others have fled. At any rate we 
have the joyous sense of freedom from competitors that we trout and salmon fishers feel when we find our favourite pool is unoccupied by another rod.

But, dear brother anglers, could I but tell you of the joy of preparation for whaling! You know how your fingers almost tremble as you undo your casts for the first day's fishing of the year, and what pleasure there is in all the preparations.

Now we are enjoying a similar pleasure, only our preparations are on a larger scale, fifteen there are of us, all doing something to help. The captain and the writer sit on the bridge and con the chart with thumb and finger, picking up the points-rocks, skerries, beacons. "Steady she is now, keep her heading for Muckle Skerry," with Isbister, Moa, Nista and Nacka skerries on our left. Another mile or two in this direction and we will turn westwards right through Yell Sound that divides the main island from the island of Yell.

A swell comes from the north and there is a fresh, pleasant ripple, and sea and sky are blue as can be expected up north in September, and everyone is busy, some on deck, some below, engineers at the engine-it takes very little attention. Then there is a jolly hot fire amidship, where the smith is busy at his forge. The mate gives him a hand with the bellows and there is the cheery sound of the ring and beat of red iron on the anvil. The bos'n, a mere lad, of fairest northern type but of much seafaring knowledge, sits in a sunny spot sewing canvas. Hansen beside him is peeling potatoes, and some of the crew bring up bolts of canvas preparatory to the task we have before us of making awnings, awnings against the hot sun of the equator. It is a little difficult up here in the north to believe there is such a thing as hot weather, when we find two ply of winter clothes none too warm in the sun.

We have our three guns in the bow still swaddled in canvas, but we will take that off and get them ready farther up the Yell Sound, and perhaps give my late host a salute as we pass Lochend.

We rather hug ourselves for having at last and at length 
escaped from official red-tape entanglements and got to the comparative wilds of the west of Shetland.

Last night before we left Lerwick we entertained the Custom House and other officials very modestly, I must here say, and they entertained us too in the way of songs and arguments and stories. A Swedish captain joined the entertainment and our evening meal of cormorants and light beer without making a very wry face at either, and later he gave us songs. He was slightly grizzled, with close-cropped beard and hair, with brilliant blue eyes, and he shook his head and beard and closed his eyes whilst he sang, and hit off some of his notes most exquisitely truly-sang Freuden's "Der ganger tre Jenter i Solen" (Three maids towards the sun went under the linden trees, and the flowers swept their skirts as they sang tra-la, tra-la, tra-la-la-la), and he quite excelled himself and shook his head twice as hard, in a dainty ditty about a maid who argued she might do many things "For mama did so when she var a flikke" ( I think "flikke" stands for our "flapper"), and verses of this he hummed and sang right into the middle of our most solemn debates on international politics. Our friend of the "wyles" and the Bow Bells accent, junior Customs officer, turned out to be Southern Irish, and for the evening at least a strong Home Ruler and Socialist. His song was too blue to catch on, but his Socialism raised Henriksen's fighting spirit to such heat that we had almost to hold the disputants. But through all the smoke and heated discussion and small amount of beer, our worthy Swede either slept or awakened and sang "So did mama, when she were a flikke," smiling and shaking his head in a most ingratiating manner.

Then we had a Gaelic song from MacDiarmid of the Isles, and Glen Lyon, and with the Norwegian national song we dispersed, the Swede still smiling, singing about the flikke, and the Cockney from Cork firing off fluent platitudes. Henriksen would hardly believe me when I told him that any Southern Irishman could be just as eloquent and excited on any side of any subject under the sun. I hope they were not all drowned, for they went ashore in a very 
small, leaky harbour boat, five souls, one pair of oars, and it dark, late and windy.

But to continue our cast round the islands for whaleswe motor steadily through Yell Sound and past Haldane's house at Lochend and its silvery crescent shore, with the little green crofts and low, misty hills beyond. We swing round his bay and blow our horn three times and by-and-by we see two figures, Haldane and his gillie, against the white house with its many little windows in the thick walls and they wave a greeting and we dip our flag three times and proceed west and north till we feel the ocean swell again, and pass Ramna Stacks, the battered sentinels at the north entrance to Yell Sound, home of cormorants and shag. A lumpy sea generally heaves about them, throwing white fountains up their dark sides. Often I have seen them when passing up the coast in whalers, and always they express a rough, rugged aspect of the sea. I have known them change their colour in a most remarkable manner in the space of a few moments, from livid yellow to green and back again, and at their feet lie many shells of great value deposited there in H.M.S. by various cruisers. This is how it happened. One day an admiral came from the outer seas at thirty miles an hour and called on R. C. Haldane and said he'd like to have a shot or two at the Stacks as they were exquisite targets. So Haldane agreed, seeing the matter was one of national service. And one morning, bright and early, my host climbed on board the admiral's ship, and in the time they had half done breakfast they had travelled from Lochend at a fearful speed to the Stacks, and then their owner saw the islands stagger and change colour; when the war vessels passed them, each decorating the islands with four shells apiece of various explosives, each patent explosive painting the rocks a different tint.

To-day as we pass they seem to be of their natural colour again, sombre black and red with a suggestion of pale green grass on their sloping tops, with streaks of white on the ledges where the sea-birds breed, undisturbed by man.

$\mathbf{N}$. by W. we steer, the wind ahead as usual, with a careful look-out for whales, the wind rising meantime till the sea 


\section{WHALING AND BEAR-HUNTING 101}

becomes too rough for harpooning; then we turn tail to the rising sea and fine rain and do a patrol southwards. As it still grows rougher and there is no sign of any kind of life, whales or birds, or whales' food ${ }^{1}$ in the water, and as we have a sheltered anchorage on our lee, we right about, and head for Colla Firth and Lochend for the night.

For we argue that we can make a more certain " departure" from Colla Firth if the weather improves to-morrow morning than we could make after drifting a night in a strong wind in the open sea.

Now we have at last a fair wind almost aft, and up goes our foresail and staysail and cheerily we hoist away at mainsail, all hands pleased to turn back from a nasty sea to a cosy night in shelter. We tramp along in great style, a sailingship once more, plus the engine going steadily. We ought to drop anchor in shelter before dark. How big the sails seem to-day, with all the reefs out. Dear me! that foresail must have looked very small indeed in last week's gale, with all the reefs in, a mere pocket-handkerchief bit of mainsail.

St Ebba lies over with the squalls off shore as we get into the wind again, but she doesn't roll much and we feel increasing belief in her as a sailing-ship.

'In these waters a small shrimp called a "krill" colours the water a rusty red for miles. 


\section{CHAPTER XIII}

For like the Duke of York

We have some stalwart men, And we led them out to the High, High Sea,

And we led them back again.

New Chantey.

W

$\mathbf{E}$ began this day with a chantey-a cheerful, fine-weather chantey. There are lugubrious songs too for bad weather or unhappy crews"Stormalong," for instance, "Stormie," who "heard the angels call." I associate that slow minor air with the dreary sough and rush of wind and seas south of Cape Horn. But to-day it was the cheery
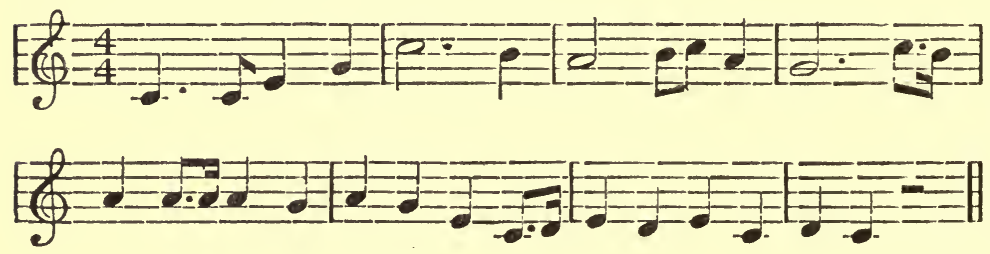

"Then blow, ye winds, hi ho, to California, For there's plenty gold, so I've been told, On the banks of Sacramento."

It's ages and ages since I've heard it, and to-day it came off by chance with a go! We were below amongst the ropes and harpoons, Henriksen and I and some men, and had rigged a hand-pump to shift fresh water from midship tank into the steward's, and we set to, coats off, four at a time, to pump, and I think the captain began; the fine weather we have struck must have given us spirits, for the chantey rang out all right; and the fellows on deck were quite surprised and looked down, grinning. Norsemen are not great at chanteys as a rule, but "California" is known pretty well round the world by all nationalities. 


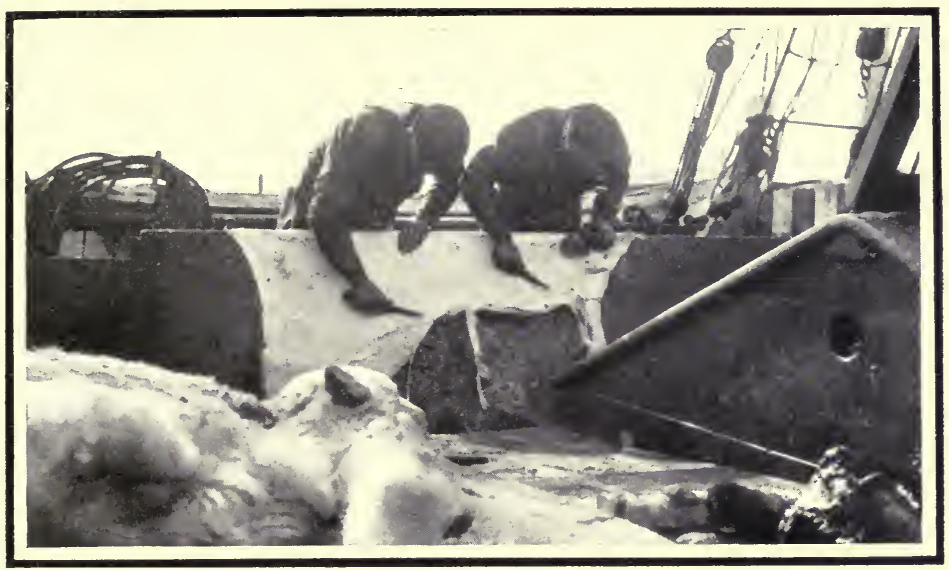

Flensing Blubber off Polar Bear Skins

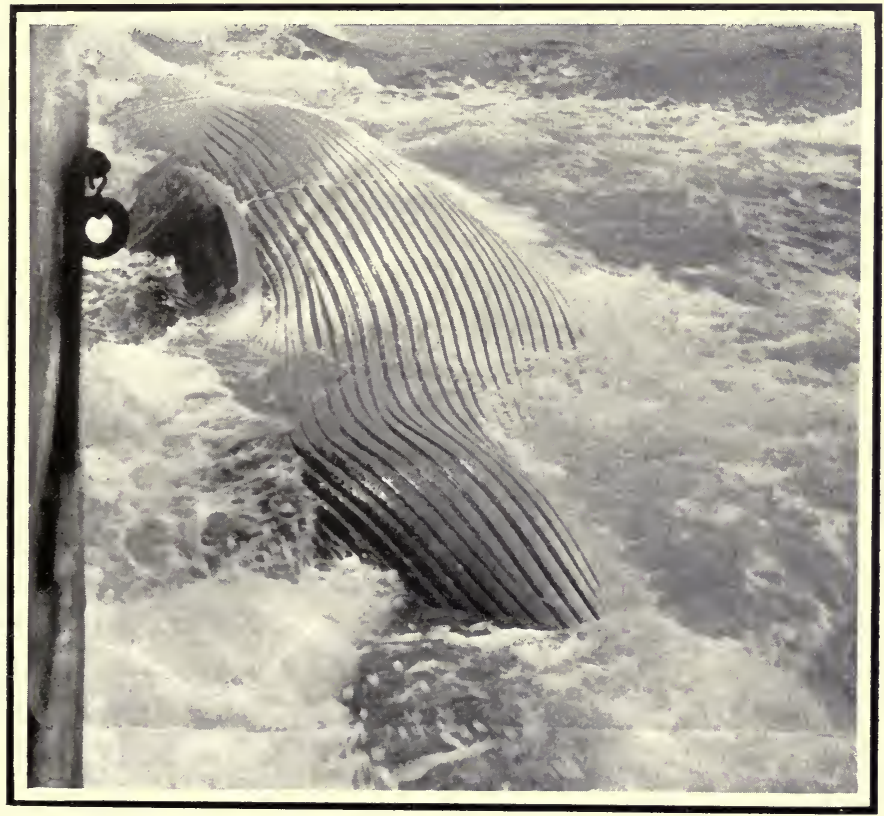

Whale Underside Up in Tow Alongside

The ribbed white of their undersides is like the white of a kid glove. 
The origin of the chapter heading is perhaps obscure. It was inspired by the fact that we reached the outer ocean, returned to Colla Firth and shelter in the evening, and dropped anchor in the twilight opposite the Norwegian wooden-painted buildings of the Alexandra Whale Company, which all the workers have left for the winter, the Norsemen to Norway, and the Shetlanders to their crofts, like bees to enjoy their summer earnings through the winter.

The morning was perfect so we weighed anchor about five A.M. As we passed Haldane's house at Lochend, the black blinds were still down and the sun shining on its white wall, so we did not as much as blow our horn to disturb its inmates but hied away for the open sea again, past these Ramna Stacks and held a course N.W. For about ten miles we kept this course till we got to the forty and sixty fathom soundings that mark the change to deep water, then turned S.W., gradually leaving Shetland below the horizon with Foula, the outlying craggy island showing grey against a pale rib of salmon-coloured sky beneath the grey pigeon-coloured clouds. And for once in a way we have what may be called a smooth sea, at least there's no white water, and alas and alas, no whales nor any sign of life in the ocean. Evidently the season is over, the Gulf Stream has been switched off.

There is still so much to do on board that there is barely time for disappointment. The whales must be somewhere, so why not farther down our Scottish coast; so we keep going south, one man only watching, all the rest of us busy with a variety of work-the artist, the first mate and a hand laying down a flooring on our main-deck or waist, made of planks we brought from the wood behind Henriksen's house on Nottero. This is to save our permanent deck, for when the whales do come they will have their dark, silky skin and firm, white fat hauled up on to this from their bodies in the sea, and there will be so much cutting and chopping and hauling wire ropes and iron flinching blocks across this waist or main-deck that our permanent deck would suffer in appearance were it not protected. And the smith is tackling a piece of ironwork, with the bos'n as assistant, making clamps to hold 


\section{WHALING AND BEAR-HUNTING}

chock blocks for the new scuttle hatch or companion we have made through the big hatch over the main hold. This being just small enough to admit a man, we can leave it open in bad weather for access to the hold.

The captain attends to a thousand and one things without pretending to do so, leaving as much as possible to the mate and crew, and has a two hours' sleep, preparatory to a night on the bridge, and works out the course on his chart. We are aiming-failing whales-at Tobermory, and at odd intervals we talk whales and prospects, about this kind of whale and the other, and the sperm in particular, that we are now setting our hopes on meeting; as the finner has not put in an appearance, the valuable sperm compared to the less valuable but infinitely stronger fighting finners. Also Henriksen looks on a little as I paint, for he is just as interested in my painting as I am interested in his pricking out our course on the face of one of those most suggestive pictures, the Admiralty charts. There is nothing more fascinating, even thrilling, to my mind than picking up this light or the other as we do to-night, and verifying it on the chart in the cabin.

Noaphead Light on the Orkneys is the first we will pick up, we should see that soon after (or before) picking up the "three flashes in quick succession" from that lonely skerry, Sule Skerry, between Orkney and Cape Wrath. Its guiding circle of radiance intersects the circle of the rays from Cape Wrath. Cape Wrath is white and red alternately. Then we will hie for the Butt of Lewis, weather permitting. St Ebba give us better weather than we met there in the Balæna, a whaling barque of the old style out from Dundee uncountable years ago-we were twenty days hove to in a wicked gale with broken bulwarks, spars, and tattered sails-twenty days between Cape Wrath and the south-west of Irelandbad spaewives did it! Now, holy St Ebba, hear our prayer. Dear saint, give us gentle winds and fair, and for what we are about to receive in the way of whales or fine weather we will be most truly thankful.

This is the first mate's birthday-he is certificated as master and has attained the ripe age of twenty-two, quite an advanced age for many a Norwegian master, and we celebrate 
his birthday and incidentally our first really fine day since we left Norway. Our skipper believes in making small celebrations on shipboard. He likes to get good work from the men and be friends at the same time, a perfectly possible attainment. All hands get a small bottle of light beer, and the steward (cook, he would be called with us) makes pastry for all hands. We begin our festive meal with cormorant fricassee, you could not escape the smell anywhere aft this afternoon. I can't quite rise to cormorant; penguins and several other sea-birds I like; but there's no accounting for taste, and our mechanicien or engineer, a Swede, simply dotes on cormorants, and regrets leaving the Shetlands and the endless supply of these hard-featured birds. Then we have the pastry, and such pastry I have never seen equalled; certainly our cook is more than steward, he is a chef! And the bottle of brandy is brought forth (out of bond, one shilling a bottle and not bad at that). Each of us has a little, and it is sent to the fo'c'sle and comes back still half full-one bottle for fifteen men and the bottle not empty! and a box of cigars goes from mess-room to fo'c'sle likewise, and comes back half full, so our crew cannot be said to be extravagant; then, to complete the celebration, Nansen, the steward, sits on the main-hatch and plays the ship's melodeon, and Rolf, the youngest on board, dances a pas seul on our new floora dance between a mazurka and hornpipe, with two or three clean somersaults thrown in. He is a pretty dancer, and of good family, I am told, too lively for home, just the sort you need on board ship. He and the steward of the pale face and yellow hair danced together. I could just distinguish them in the dark from the bridge against the light planks of our newly laid working deck. For a moment, whilst the skipper played, my heart. stood still! for the steward nearly went over our low bulwarks at a roll from the swell-his exquisite pastry flashed across my mind.

We saw Sule skerry twinkling in the night a few miles to starboard. I would like to make a visit there, it would be such a soothing place to live on, the solitude must be so emphatic, for it is equidistant from Orkney and Cape Wrath, and out of sight of either. In the morning the light on Cape 
Wrath went out and we saw the beetling cliffs backed with high, bare ridges of the Sutherland mountains against a yellow sunrise. On a soft, rolling, rippling sea and far off, a mere speck beneath the cliffs, we made out a fellow-whaler (only a steamer), with its long trail of smoke beneath the cliff steaming east, and we thought she was the Hebrides, one of the steamers of a small company, the Blacksod Bay Company in Ireland, which I wish well. Evidently it was on its road to Norway, so we gathered that whales must be scarce and the weather probably bad on the Irish coast.

Our saint has answered our prayer, and instead of the wild weather we associate with these parts we go comfortably along at eight knots, with the engine singing a soft song to its gentle beat. What a difference between the lot of the motor engineer at sea and the steamer's engineer, the motor man in a pleasantly warm, spacious room, the other in cramped space with considerable heat, and the clanging of stokers' shovels.

Past the E. of Lewis we motor steadily. One killer or grampus we saw, and about a dozen dolphins in the three days' run south, and very few birds. So we felt confirmed in our belief that we should proceed to Southern Seas now, instead of waiting for whales in northern latitudes. Evidently the season here is over.

Now we have Neist Light and its double flash, to port, and we pass Dunvegan and wish we could see the familiar mountains of Skye. But the light is all we have, and welcome it is ; past it a little and we will have the light on Hyskeir Rock to guide us on our way till we pick up Colonsay and our old friend Ardnamurchan, and the light on its point where the white-tailed eagles used to breed.

Burns said: "Man's inhumanity to man makes countless thousands mourn." If he had been picking up lights from Flugga on Ultima Thule down our intricate west coast, with its tides and islands, on a dark night, he would have held his breath with the thought of all the human effort and forethought these lighthouses express of man's humanity to man-to our countrymen, to my Norse companions, to the Russian trader, whose light we see to-night not far astern; 
nation to nation offering kindly guidance and warning. So we have various colours in the night, the pale flashing lighthouse we steer to, and two golden eyes from our galley casting patches of light on deck, and on either side of us a phosphorescent Milky Way with occasionally vivid flashes as we turn over a wave in the smooth water.

But it is to bed, to bed, for to-morrow we must be astir early, to meet relatives in Tobermory, and anchor in its circular bay, where we have so often anchored when we were young and unspoiled, and Mull to Ardnamurchan in a dinghy seemed a long way, and whaling was as a tale that is told.

At four o'clock in the morning we pass Hyskeir Rocks, pass them three cables to starboard. It is dark and hazy but their light sweeps across our deck: soon the lights on Ardnamurchan and Coll greet us; and as sea and mountain and air faintly separate, we pass the light on the point and pick up Kilchoan, and then the Tobermory Light.

Ardnamurchan shows a rugged, mountainous outline against the morning sky, and to a stranger coming from the sea, picking up the lights as he goes, it seems inhospitable. But to the writer it recalls some similar mornings-after smoky town down south-coming up for winter shooting. What glens there are of birches for black game, corries for deer, lochs for little brown trout and burns for sea-trout! My thanks to relatives for the free run we had when we were young-Ardnamurchan Point to Glen Borrodale, what a playground! North beyond the point and the hills above Kilchoan we see the hills above Loch Aylort and the coast of Morar, "Blessed Morar," perhaps the most beautiful spot of the most beautiful country in the world. Where else do you find stone pines, in deep heather growing right down to a white coral strand, and glass-green sea-water. Then Drimnin and Glen Morven appear west and south of Ardnamurchan, full of memories of relations, of piping, singing, hunting and sailing.

The relatives, we presume, are all asleep now, so we won't awake them, as we pass, with repeated blasts on our foghorn, as we half thought of doing-no, we will later rouse them up with a Fiery Cross reply-paid telegram from Tobermory to 


\section{WHALING AND BEAR-HUNTING}

come across the sound to see this newest whaler. Possibly we will, after considering mundane matters, such as potatoes and marmalade for all hands, drop anchor at Drimnin or Glen Morven and ask the relatives to step off and see our wonders on board ship, but the anchorage at neither of the places is of the very best and Tobermory is perfect.

My Norse friends fell in love with Drimnin and Tobermory and its round sheltered bay at first sight: we had only too short a stay, for a wire told us my cousin, Mr C. H. Urmston, a fellow-director in our Company, would await me in Oban, so we up anchored, went over to Morven and dipped our flag and blew the horn opposite Drimnin, and passed the Urmstons' house, Glen Morven, in silence, for we hear it is let to a stranger from the south, and down the familiar Sound of Mull we proceeded on this lovely summer afternoon to the Great Oban.

By the way, I met two men interested in whaling in Tobermory! When your mind runs on a subject, is it not odd how many people you meet who also take an interest in same? This man is Yule by name; we met on the subject of bagpipes; piping is the best bond and introduction to the best men! So with two interests, whaling and piping, you at once get very intimate. He came from the east coastI never met a Highlandman whaler, and not often a sailor (they are generally Captains or Chiefs, they have brains).

"Did you ever hear the name of Yule as a whaler?" he said; and I replied I'd heard more stories about Yule and whales and white bears and Arctic jokes and adventures from Dundee to north of the Pole than of any other man alive or dead. "Well," he said, "that was my grandfather," and he referred me to his father up the close, to verify the grandfather's exploits. So if anyone who reads this wishes yarns true and hair-curling about Greenland's icy mountains, etc., let him call at Tobermory, on Yule senior, No. 51, the third close past the post office.

A fair lady at Tobermory graced our vessel with a fleeting visit, Miss Sheila Allan, of the famous line of that name. She rowed from Aros Castle in her dinghy and sprang on 
board, leaving her collie in charge, overhauled our strange craft, fore and aft, sprang into the dinghy again, a mere cockle-shell, and rowed off again half-a-mile to windward, against a fresh breeze, as if it was the most ordinary everyday thing for one of our ladies to do; many a fair Brunhilda could have done the same. I did not tell my Norse friends that she was at all exceptional, so our Norsemen have formed a lofty idea of Scotswomen as mariners. I wished they could have seen her, as I have, out on the Sound of Mull in wind and rain, fair hair flying, yellow oilskins dripping, racing her own cutter, three reefs down, through the spray for the Tobermory Cup. 


\section{CHAPTER XIV}

WHE British fleet lay at Oban; I don't think any wars-man on any of the vessels would not have

1 changed places with one of us; for to any seaman there is an air of romance and adventure about a whaler. I'd have felt distinctly proud passing down their line in our little vessel whose object and capabilities any bluejacket could guess at-a motor, plus sails and a small but seagoing hull, a business-like gun at bow, a crow's nest; and going south - that would appeal to their imagination. But alas! at our stern hung a Union Jack made in Norway, that a Boy Scout would jeer at. I am to blame. I'd taken it for granted I could get a Union Jack anywhere, but the Norse idea of a Union Jack I cannot recommend. But the warships politely dipped to us, and the crews crowded round their bows and we could only imagine the smiles at our Jack. We may perhaps still manage to get one of the correct design in the north of Ireland if we call there. In any case, our mistake was accidental and temporary; but each of his Majesty's ships flew the Cross of St George with the Union Jack device relegated to a mere canton, a deliberate violation of the Treaty of Union, the first article of Treaty which stipulated that the united crosses of both Scotland and England shall be used in all flags both at sea and on land.

We spent the Sunday afternoon as John Knox and the reformer used to spend it. I mean we enjoyed ourselves " out-by." John Knox, you know, golfed on Sunday afternoons, and ate oysters in a High Street cellar at night! So we sailed, and then dined in the Station Hotel. My wife and my cousin, Urmston, had come north to Oban to avail themselves of the chance of seeing the St Ebba; and with a light, fresh breeze and smooth water we sailed and motored over to Duart and South Morven, and Loch Linnhe, and at night dined on shore as stated. The engine had 


\section{WHALING AND BEAR-HUNTING}

worked perfectly; Urmston, a born mechanic and sailor, was delighted with the whole turn-out, so it was rather a jolly dinner and there were many yarns.

One of the subjects that came up was that of wives at sea. "Ach, vifes at sea's no good," said Henriksen emphatically, and I was rather surprised, as I know Norwegian captains often take their wives to sea, but Henriksen has been, as a boy and mate, a looker-on, and has seen trouble come from it.

"No, no," he continued, "alvays bad veather and trouble ven veemen's on board. I tell you vonce a veeman come on board-I laff! We vas in a barque and the captain's vife she owned it-she vas very reech, and had tree sheeps. She vas married tree times-the captain tell me dis, he vas her tird husband." Henriksen was serving his time on this barque as all Norsemen do, on sailing-ships before the mast. At Boulogne they lay one night alongside the slip, and all but he had gone on shore to the cafés. He being youngest had to do watchman, and brewed himself coffee in the galley and then dozed, possibly slept for "five minutes or maybe two hours," he said. "I do not know, and ven I vakes up I looks out and dere is a light in cabin so I goes quiet and looks down the skylight and der vas a great veemen! with luggage on de floor beside her."

Down to the cabin went Henriksen and addressed her. "Who is you, vat you come here for without leave?" To which she replied: "I am the captain's wife." But the boy would not be bluffed. "That is not true," he cried, "go away at once, you'se bad veemen, you comes here to steal, be off wid you before I gets the crew or the captain comes."

And she looked round her and rose and reached to a young woman's photo on the wall and held it to Henriksen and he gazed and saw the truth; this elderly spacious person still preserved some faint resemblance to the buxom girl in the faded photograph. So Henriksen made his bow-you know how the Norse bow, straight from the hips, and apologised and asked forgiveness, which she very graciously extended to him, saying: "You very good boy, you look after ship well." So he chatted away pleasantly, and got her coffee and food and retired again to the galley, and when he was 
sound asleep again, the captain came from the town, jumped down on deck and came growling to the galley: "Hillo, you're a nice watchman! asleep in the galley, when you should be on deck." "Well, captain," said the boy, "I work all day hard, and all night $I$ vatch and den comes your vife and I cooks for her long times, what you expect?"

"My wife," whispered the captain anxiously. "Evan, here's something for you, put that in your pocket and keep it, and promise not to say a word about my coming aboard."

Henriksen promised, and the captain turned and stole away along the dark quay.

In the morning a wire came to the first mate-I think it was supposed to be from Antwerp-saying the captain was on his way home to meet his wife in Norway, on which the fond creature said she would at once return home to meet her good man, and she went. An hour later the captain appeared on board, and they made sail for Valparaiso.

My wife said: "That's a most excellent story, Captain Henriksen," at which he protested solemnly: "No, no, dat is no story, dat is quite true, I tells you." And we had to explain the differences in our language between the "story," an incident, and the "story," an untruth; if you try, you will find it is rather difficult to do this. The language question again!-how often it crops up. I wish I could speak Norsk properly; I have to worry along with English. I was told to-day I can speak that difficult language very well. We had all been speaking to the lighthouse service captain for quite a long time when he complimented Henriksen on his English and flatteringly told me I spoke it even better, and I explained I'd made a study of it for about half-acentury, and in fact had the honour of lisping my first words in his own part of the country.

That incident was slightly amusing: but halting English nearly got our Swedish motor inspector, whom we met at Tobermory, into serious trouble. He is such a nice-looking fellow, too, I felt quite sorry. He waited there for our arrival peacefully for three days at the Mishnish Hotel, putting in the time sketching. One day he made a drawing 


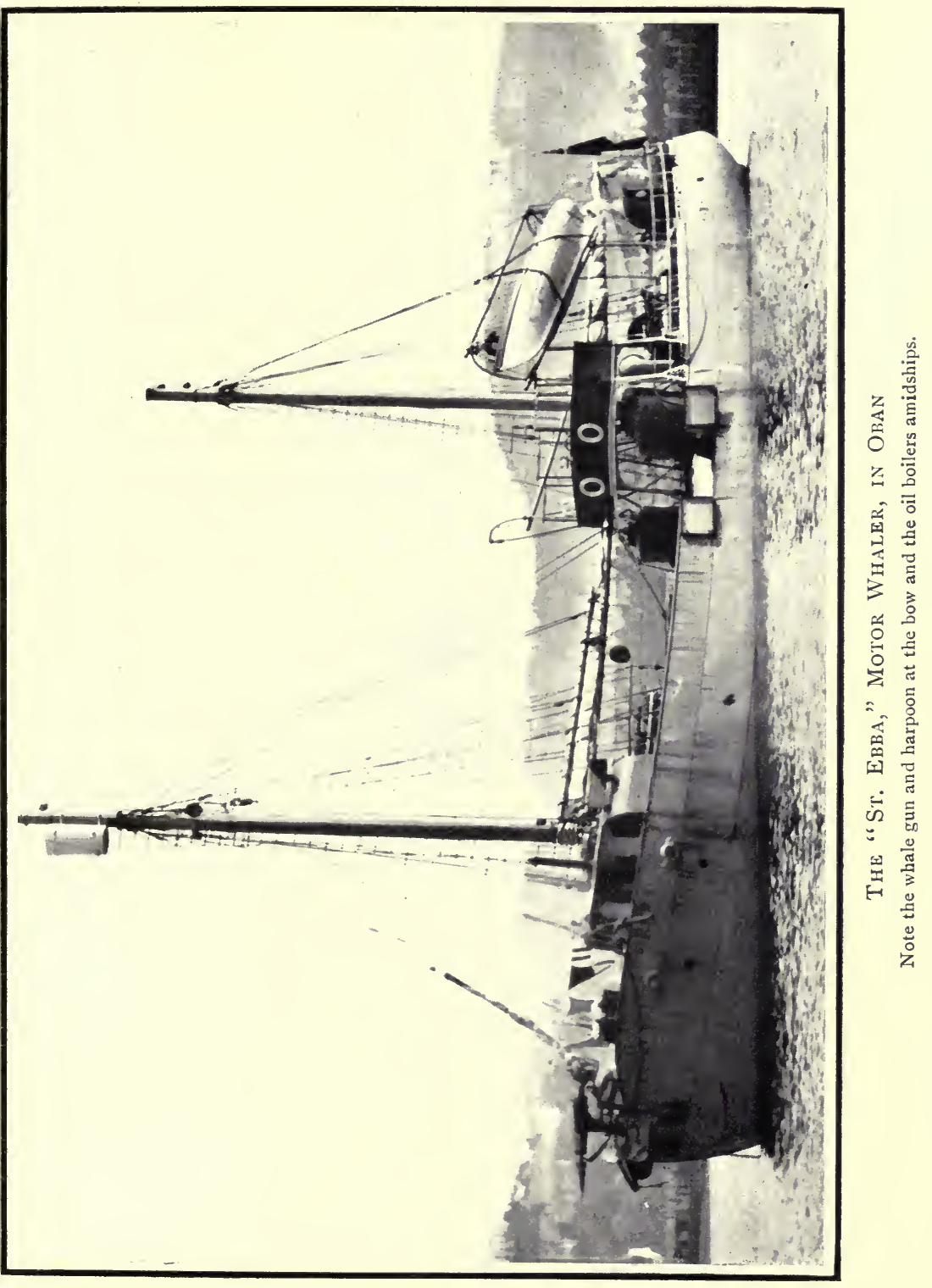



of Aros Castle, the Allans' mansion, and as he lay in the grass and ferns under the birches his thoughts went back to his professional work and he drew plans and symbols, and a native came dandering along, full of the kindly interest the west highlander takes in the stranger (I like it myself, but some people call it mere curiosity), and he ventured: "You will shust pe arrived, maybe by the Lochinvar? Aye, aye, shust so, she's a wonderful boat. Aye, you will be from Glasgie? That's a fine toon Glasgie. I wass there for the Exheebition. Och, no, you will not be from Glasgie. From Sweden! Do you tell me so ? ma Cot! that's a long way. I see, I see, so you will be a foreigner. Weel, weel, I will wish you a coot day," and he went. But he had seen the symbols, and he knew the Fleet was at Oban, and he had been reading the papers about invasions, so when he met the policeman, who pays a visit to Tobermory once a year to sign his name, he said to him that "there wass a lad at Aros, in the 'furrns,' drawin' plans and things-roould he be a spy?" After due consideration the policeman decided to walk round the bay. It is not very far round the bay, not far for anyone but Tobermory natives, who are restful people. I once saw them watching Aros Castle on fire with their hands in their pockets, and it never occurred to them to trot round the half-mile to help.

Well, the policeman did not go quite round the bay, for he met the young man coming back and he said: "It's a fine day, Mister, for the time of year, and you will haff been drawing?" - and asked very politely if he might see the sketches; in the West we are very polite, for the climate is so mild. And as the young Swede modestly refused to exhibit, MacFarlane accompanied the visitor rather silently till they came to the famous Mishnish (famous for drams since the Flood), and then the young Swede began to see the humour of the situation, and allowed MacFarlane to examine his baggage, and got him at last to understand, with great difficulty, for he only spoke very little English, that he was waiting for a Diesel engine motor-whaler called the St Ebba, and mentioned this writer's name, which made it all right with MacFarlane. And the hotelkeeper, and one or two friends 


\section{WHALING AND BEAR-HUNTING}

of the policeman and the hotel proprietor came, and they had quite a pleasant afternoon and evening: for as the sun shines there are soft drinks to be drunk and tales to be told in the Mishnish Hotel in Tobermory's sheltered bay any day of the year round.

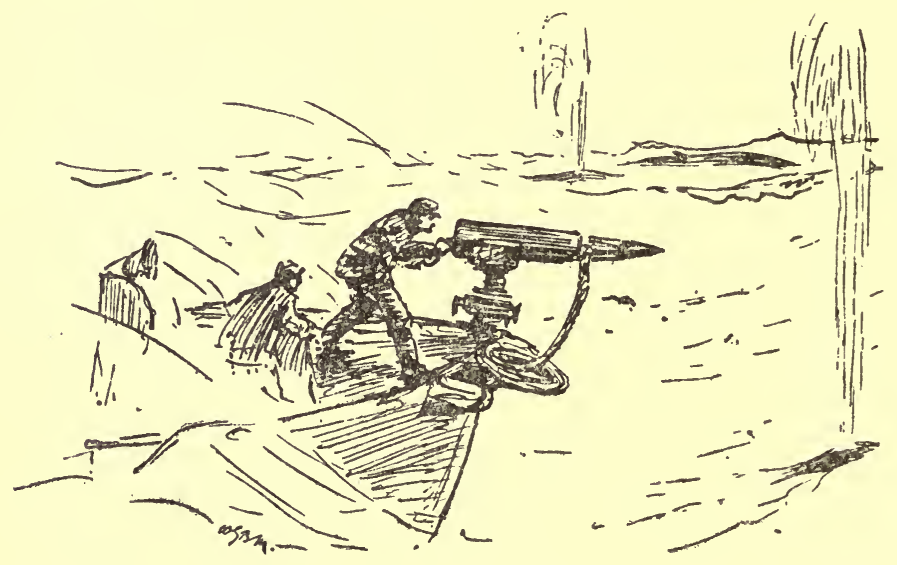




\section{CHAPTER XV}

" It was a' for our richtfu' King

We left fair Scotland's strand,

It was a' for our richtfu' King,

We first saw Irish land, my dear,

We first saw Irish land.

"Then right he turned and round about

Upon the Irish shore

He gave his bridle rein a shake

With 'Adieu for ever more, my dear,'

With "Adieu for ever more." "I
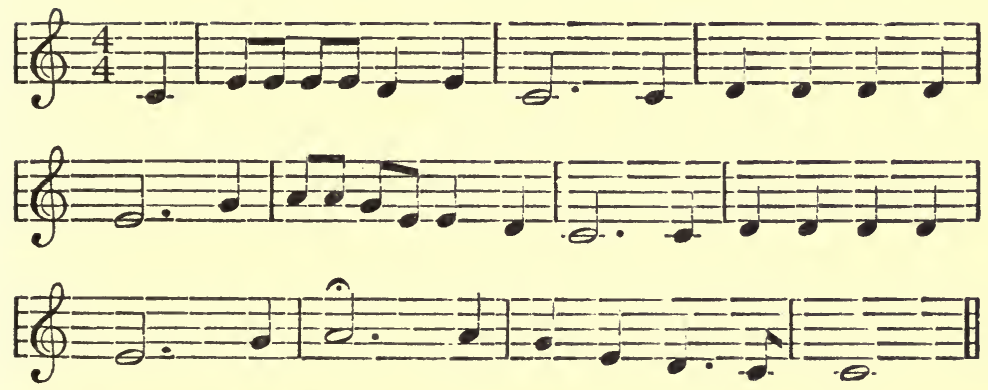

O one knows who wrote these words-some mournful
Jacobite, perhaps, who felt as the author does;
for though the night is perfect, with the golden harvest moon reflected in a sea like glass, we cannot but feel a little sentimental on turning our backs on relatives and on our dear West Highland strand (especially during the shooting season).

The tune fits the words, does it not? I think it is a recollection of an old sea-chantey I once heard-coming back to mind to suit the words, and what might seem to be the mournful cadence of our Diesel engine and the sighing of the glassy water as we surge gently across the swell. I wrote before of the musical notes of our engine. I do not think my cousin Urmston or Henriksen notice it much to-night, for 
they are too absorbed in whale talk. My cousin left desk, and shoots, and engagements, to come with us to the Irish shore to see us as far as Belfast, and to go over our business papers, but pipes and whale talk and more pipes and more whale talk, and minute examination of the engines, seem more to their taste at the moment than business papers by lamplight. Belfast docks will be more the place for business than the Sound of Islay, with Jura and the day fading and a night full of the yellow light of the harvest moon. A joyous change for the family lawyer, is it not-from the city to the coast he dreams of in town-from the busy office to the quiet of the Highlands and islands-from affairs of companies to the picking up of the lights on Islay and the Mull of Cantire ? We hoped for his sake to see a killer at least, or something to fire one of the guns at-several finners have been seen lately on the Scottish coast. But as the morning dawned it grew rough with thick haze, and it was all we could do to pick up Black Ness and then the entrance to Belfast Lough. We are not proud, so we took a pilot and felt our minds at rest as we steered up the three miles of buoys which mark the channel almost as close as lamp-posts in a street.

If you have not seen Belfast I give you my word that the first impression is astonishing. You can hardly believe you are not dreaming. The iron network of building leviathans in course of construction is overpowering, enormous, so vast is the perspective of not merely one or two great iron ghosts, but streets of them, high as buildings in New York, one beyond the other on either side of the river, fading into smoke and distance, and the noise of iron hammering and banging is universal, so all-pervading that you hear yourself speak quite easily. We felt like a mere speck crawling up the grey river. By-and-by we noticed little mites moving about in these gigantic structures of iron filigree-work, high up on stagings, or higher still on vast cranes, up in the sky ; these were men, twenty-six thousand of them in one yard alone! We met them later, in marching order, hefty fellows, blueeyed, drilled Ulster Irishmen, stronger looking than Scotsmen. Later on we saw them sign their National Covenant. These are descendants of the people who gave Scotland its 
name. Few there are who know this. Men learn about the Kings of England and of Israel, with their dates, at public schools, but never a word are they taught of the far longer, far more dramatic and interesting succession of Scottish kings, previous to their succession to the English crown. Not one in a hundred knows that the old name for Ireland was "Scotia," that it was not till the seventh century that the Scots of Ireland gave their name to Alba, to the United Scots and Picts of Britain north of Tweed, our Scotland of to-day. But we are verging toward dangerous ground-let us get to sea again and continue to chronicle on the rolling deep, and let Erin go bragh.

Erin goes fast away on our right-a violet line between white-capped greenish waves and a grey, windy sky. We came down Belfast Lough against dead head-wind and proudly passed much larger sailing craft than ourselves waiting in shelter for fair wind, and having hunted for a boat in which to deposit our pilot! We got out to sea, set sail, and have again become a sailing-ship with a strong breeze on our quarter. We knocked off eleven knots an hour, leaving tramps and such-like behind us. But what an awful appearance we have! Four days alongside the quays in Belfast, with coal-dust flying everywhere, have made us like a collier, rather hard lines, considering we make no mess coaling ourselves as others do. What a change there will be in the amenity of seaports and all towns when oil takes the place of coals. Imagine a clean town-Edinburgh, for example, and the beauty of such a dream!

It was the air pump and the connections between our oil tanks that brought us into the thick of great events-into "Ulster Day" and the signing of the National Covenant, and a small matter (hunting for some flexible iron tubing) brought us into the great and beautiful City Hall. I am sure few people have heard what an exquisitely designed building this is-indeed, what a very handsome town Belfast is, taking it all round. And the people! how I wish my northern countrymen knew what they were like in the mass. How very like themselves, both men and women, but perhaps 


\section{WHALING AND BEAR-HUNTING}

rather bigger and stronger than the average Scot, and as reliable-looking, and yet perhaps a little happier than we are, even in their anxious times.

I don't think our Norse crew found Belfast altogether a bed of roses. Some had shore leave, with five shillings each to spend up town. Our cook, or steward, told me of their adventures. He heard of them from the watchman, who was made their confidant. Now they are ship's property. Seven of them, all young fellows, "very greenhorns," said the cook, washed, put on celluloid collars, brushed up, and sallied forth at night, and they had barely got to the bridge along Queen's Quay when three of them had given their five shillings to maids of Erin, fair, frail things in shawls, and the coy creatures fled and the three came home to the ship lamenting - so the watchman said. The others, to a certain extent, enjoyed all the tumasha, and, to be sociable, bought a penny Union Jack buttonhole, badges that almost everyone was wearing; what they signified they don't quite know yet. It was jolly lucky they weren't killed. They went up Bally Macarack Street, in the heart of the Roman Catholic district, and were mobbed by Nationalists, fifteen girls and a dozen men. Happily the police arrived in time. The tallest of our crew got a severe kick on the part he sits on, and the smallest got a "shock," as he said, on his eye, and they say: "If we lies here in Belfast one years we no go shore again! No fears ; dem's folk's mad, dem's crazy! What's all that for-dumna 'Ulster' dems shouts all de time?"

We are picking out our course to-night (Monday) on the chart rather comfortably in the cabin. It is smooth and we are in mid-Channel, in the north-west we have Holyhead Light. We forecast a run of luck for ourselves. We've had our share of head-winds and little difficulties since we left the south of Norway, so with the compasses we mark out six days' run as long as to-day's run, which will bring us to Azores in six days, or seven days sure, if we have a little strong fair wind-we won't think of nasty rough weather.

But "Just about here," the compasses pause, "I was three weeks," said Henriksen. "That Christmas was the 
roughest time of my life," he continued, puffing at his new calabash.

"We was on the Kron Prince three weeks out from Cardiff, seven feet water in the hold and the pumps won't work." They had reached the Azores and drifted back to the Bay, then to the Irish Channel, and got shelter, I think, in Bridgewater.

"Captain and mate they's on deck, with revolvers, but we get ashore and run away. We was not going in that for-dumna sink ship, I'se sure. No! tree hours at wheel was my last watch, one hour pumping, cold, wet, then I finds in corner of fo'c'sle three biscuits, one half-cup tea cold, dat decides me!" "How did you get off ?" I said.

"With a runner-runner come alongside : we cuts square hole under fo'c'sle head, captain and mate, they looks all round deck, but not below bows, and we slips out, eight of us and our bags."

Perhaps these eight were justified for the Crown Prince got a new crew and sailed, and was never heard of again.

Henriksen had three guineas sewn in the waistband of his trousers, and a lot of sense besides for eighteen, also his mate's certificate, although he was only a sailor on board, and he reflected, as he went ashore, on what he knew of runners and their ways : how the sailor is kept by the same on the credit of his next two or three months' advance wage, and then goes to sea with precious few clothes and say five shillings to land with at the next port, and has therefore to go to another runner until he gets another ship, and so may be at sea two or three years with hardly the sight of pay. So on getting ashore Henriksen made a clean bolt to the nearest railway station, jumped into first train, taking ticket to first station, leaving his bag with the runner, of course, but keeping his mate's ticket. Where did he say he got to ? I forget, somewhere near Liverpool, but five or ten miles he did free of charge as the guard was interested in his recital.

From Liverpool he booked third class to Belfast. It was a wild crossing and he met, strangely enough, another runaway, an Englishman, and isn't this the making of a story ? They befriended a would-be second-class passenger and his 


\section{WHALING AND BEAR-HUNTING}

wife, who were obliged, by overcrowding, to go steerage, and both these people were helplessly sea-sick, and their poor children just rolled about the floor till the two young seamen took care of them, and held them in their arms all night. The father pressed a whole $£ 1$ note on Henriksen, which he refused, as he had plenty of his $£ 3$ remaining, but the Englishman was stony, and he was persuaded to take ten shillings, and the parents gave each of them their address.

Afterwards Henriksen called on them-and such a fine house it was! Henriksen reflects now he might have called on these old friends in Belfast this journey. "They must be old people now. Next time I come to Belfast," he says, "I calls-maybe they's in life."

At Belfast he went on a local tramp, then got berth as second mate, and had twelve months at sea without a day ashore. For it was to Bahia that he went, where you anchor almost out of sight of land. For I forget how many weeks he lay at anchor, then sailed to another port, twelve men in the fo'c'sle, seven with monkeys, the rest with parrots, fancy the racket! then to Mobile Bay and then back to Troon, "two houses and a wall," as he describes our charming little Scottish seaport, then home to Norway. That is all you sometimes see of foreign parts if you go down to the sea in ships. Nine months at sea with one night ashore is the writer's longest spell of salt water, but Henriksen tells me he knows of a man being twenty-seven months at sea without getting on shore. I think I must make a special book of Henriksen's adventures. As told to me they are interesting, but our surroundings count for a good deal : over a chart in the little lamplit cabin or on our quarter-deck (three steps and overboard), the moon overhead, and our sails looking dark and large, and our AEolian engine singing its steadfast song.

Though only a little south of Ireland, we have the real swell of deep sea; rolling low hills that leave no level horizon to us, for we are so close to the sea-surface, long, gentle undulations that suggest a perfect golf-course for elderly people.

We have a steady air from the north-east like the Trades. Possibly we may never have to shift a sail till we reach 
the Azores, and certainly to-day there was that in the light at midday, the sharp shadows on faces as we took the sun's altitude, that, even with a pigeon-grey sky, reminded me of southern light that I have not seen or felt for several years, and we did things with our coats off, and brought our rifles on deck for an overhaul.

Our Norwegian heavy bores for sea-elephants cost £3, and as far as I can see are extremely accurate at the short range. I have tried them at one hundred and one hundred and thirty yards and they do not burst. It will be interesting to compare the effect of my higher velocity sporting mauser, a 375, with their work. Possibly the larger bullet of the Norse rifle, about 500, may be more useful for this huge animal at close range. The Norsemen are sure of this, but I back the bullet with the higher velocity every time.

There is a gale this evening and we are running with reefed foresail. 


\section{CHAPTER XVI}

I

T is a strong N.E. gale, but "Muckle word pass ower," as the children were taught by a certain dominie in the north to repeat when they came to a word beyond his knowledge, so "Muckle gale and pass ower," we say, and try not to think of it. Why dwell on the unpleasing side of the sea. It is beastly all the same, and trying to one's nerve.

We have no canvas on her now, just tumble along before the wind, with bare poles, through the grey seas, the wind passing through to our bones, wet with spray, weary with the motion. Henriksen says: "To-morrow ve vill be into the feene vedder." I don't know which is best, to be alongside an optimist or a pessimist in a gale at sea. An old skipper used to murmur to me in evil, dangerous times : "Hoot-toots, we'll be oot $o^{\prime}$ this intil a waur" and I begin to think this grim pessimism was really more comforting than Henriksen's sanguine forecast of fine weather and blue seas which, I think, are far off.

All the same I notice to-day that as we bury our stem and the water roars over our deck, the little light which comes through the seas into our round bowley aft has a watery tint of blue instead of the green it had yesterday. That is, I take it, because we are out into the deep sounding beyond eighty and two hundred fathoms that encircle our shores past the great Sole bank, on the S.W. of England and Ireland, and now have somewhereabout two thousand fathoms beneath us. We thought of heaving to last night and had a trysail ready for the aftermast. It was very black and awesome, but we managed to hold on our course. It is rather risky heaving round head to wind after you have run till the sea is dangerous. If you do not put down the wheel at the right moment you have a chance of getting one of these black seas and their huge white crests full on your 
beam or bridge and perhaps becoming a wreck in a second. It was as if the lights of cities at night showed every instant round the low horizon every now and then, to be blotted out by black hills, the light of the phosphorescent white ridges of foam.

Seizing what we think is a lull between big waves we scramble across the wet deck forward to our small messroom, pause as we hang on and swing, till the iron door is almost upright and dive in. The door shuts with a clang. . . . How the wind whistles as the new-comer opens the little round-topped iron door! But once inside there is peace and warmth and lamplight and steamy air from the cooking stove, and we have sardines and bread and margarine for dinner, for it's too rough for cooking more than tea. Then out into the black, wet, slippery deck again. Phew! How it blows, and how difficult it is to see now! Then to the bridge again and the St Ebba beneath us, a patch of black with two lights like eyes shining aft from the galley, a mass of dark against the wicked white of the surf which we tear in the dark sea-a black cat on a white bearskin, in a halflit room. I suggest to the styrman (Norse for first mate) and captain as we shiver (I do at least) on the bridge that a Rolls Royce motor car on a hard, dry road isn't so bad, and they shout with derision. "No! No!" the St Ebba for them, driving before a gale. I wonder if they really mean it ! Anyway I must pretend that I like it too.

A chunk of green sea came over our poop and bridge last night, banged on our iron cabin door which faces astern with a thunderous shock and swept over the bows. Some went over the bridge, and a lot came down to the cabin, enough to be unpleasant. Out came styrman like a rabbit from his bunk, and I'm pretty sure both the writer and captain's colour was not suggestive of pure joy. In a brace of shakes, after this big wave broke over us last night, Henriksen was at the wheel and the engine going againthe engineer had stopped it for some reason, perhaps to let our decks clcar off the sea. Then sacks with waste and oil were rigged out on either bow, and we continued, the seas breaking angrily but out of reach of us. So we drove through 


\section{WHALING AND BEAR-HUNTING}

the night and are satisfied, and won't do it again. We did ninety miles in the night with practically only two seas aboard, and we do not believe there's a boat floating of our size or bigger that would do the same, and we forecast our style of stern and lines under water becoming the fashion.

This morning we have a bit of foresail up again and

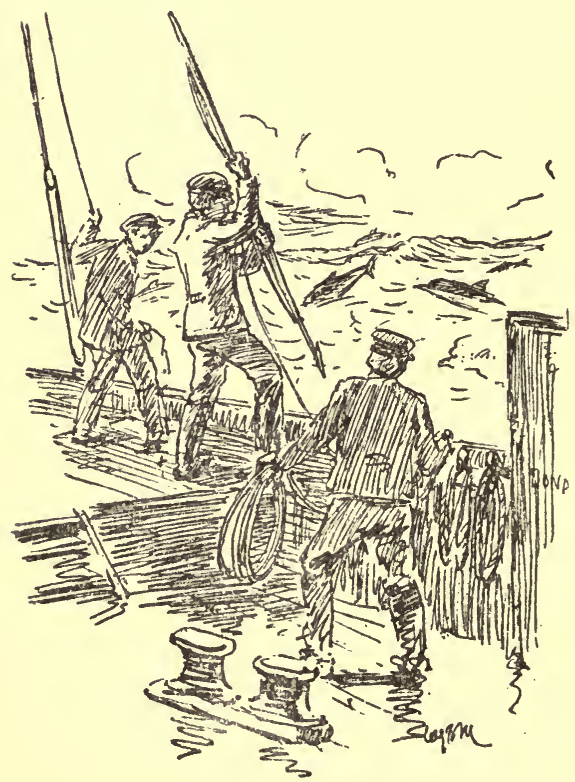

an experimental jib as storm trysail on our mainmast, and it seems just to be right. ${ }^{1}$

I thought I had missed sport by writing these notes and not turning out early, for when I did put up my head into the wind and spray, the mate was silhouetted on the bow, harpoon in hand, with figures grouped round him, holding lines, in attitudes of intense expectancy, and there were dolphins springing alongside. But it was too rough. Several

lunges were made by various members of the crew with our little hand harpoon and its long spruce shaft, but they were misses all. The sun shone about midday, a small incident, but after three days' storm and heavy seas it was a cheering sight, and the sea became blue, but always too rough to get a harpoon into the dolphins. They appeared again at night. The sea was full of phosphorus, so we could see their brilliant tracks shooting round backwards and forwards like the trail of rockets. Though I have been amongst hundreds of

${ }^{1}$ Later we learned that three s.s. of several thousand tons were hove to during this hurricane. Bravo, St Ebba! sixty-nine tons, one hundred and ten feet, and the safest boat in the world. 
whales at different times and seasons I have never had the luck to see one going through a phosphorescent sea; but Henriksen tells me a year or two ago, off Korea, he tried to harpoon one in the dark, aiming at the glare as it passed alongside. He could scarcely see the gun and fired a bit too far back, I think at the light, instead of ahead of it, and missed and saw the yellow blaze of light under water as the shell on the point of the harpoon exploded. "Ask me if that whale went fast," he said.

It is Sunday, the 8th October, an idyllic Sunday; there's a grand, blue, rippling swell, and enough air to keep our sails spread, so we roll gently along, a block creaking occasionally and our little engine throbbing beautifully. But there is a slight feeling of annoyance aft, and it's easily understood. Our skipper has his idea of what Sunday at sea should be when there's no whaling or hard sailing to attend to, and I agree with him. He thinks all clothes-washing and drying blankets and mattresses should be done on Saturday, Sunday should show clear decks, shaved chins and, if possible, a change of clothes and mind. But most of our crew apparently have been brought up to the common idea of Sunday as washingday and have hung up shirts and clothes of all kinds everywhere. Henriksen endures the un-Sundaylike display but vows "never again." Next Sunday we will be neat and clear, or all hands will be working double tide at flensing or hunting whales-we shall see!

Meantime we have had days of quiet ship work, the sea getting more blue each day, and winter clothes shedding. On this account we held a shoppie on Friday-got out the captain's slop chest from the hold. This is an old sailingship custom. Six of us carried it aft to quarter-deck, unlocked it and took all the contents into the little cabin, and wasn't it a well-stocked shop-jerseys, trousers, boots in cardboard boxes, caps, shirts, woollen gloves for the cold northern seas, and white and blue dungaree suits for tropics, and scented soap! It was new for me to see scented soap on such a business. Henriksen and the first mate have a busy afternoon with their coats off and pipes going, looking up prices and calculating the ten per cent. profit- 


\section{WHALING AND BEAR-HUNTING}

a small profit to cover risks-and good articles. I've seen fifty per cent. made off very inferior goods. And the crew come down one by one and buy what they need or can afford, and "ask me" if the atmosphere doesn't get thick towards lamplight time.

There was not much sale in the way of winter kit. The heaps of mits and thick woollen socks will not be appreciated till St Ebba gets far south towards the ice edge.

With our present crew of Norsemen it is not so easy to get interested in them, individually, as with sailors of our own race; still the few words we have of each other's language, eked out with signs and drawings, go far-drawings especially; indeed, from the captain downwards, painting excites far more intelligent interest among our crowd than they would with my own countrymen. Our old Dundonian whalers were neither very musical nor artistic. Here the skipper plays Grieg, and has a lively interest in every æsthetic aspect and every change of form and colour in waves and sky, and has actually taken up water-colours and playing on my bagpipe practice chanter, but I fear that for neither of these will he be able to spare time, for a skipper is, or should be, practically on duty all the time. But his first attempt at water-colours-a blue sea and white breakers under a blue sky-was not half bad. The blue sea was there all right, but the rhythm of the waves and the half tints, who can do them justice ?-Wyllie, to a certain extent, but I cannot remember anyone else, unless Colin Hunter, and he is dead.

It is a real day of rest, contemplation and dreaming. Our greatest effort has been to rig a line for dolphins. Both the trolling tackles we had out were carried away last night, so I unearthed a tunny hook I had fastened to a wire rope with a strip of aluminium to act as spoon bait. Now that is trolling astern for the benefit of any wandering albicore, tunny, bonita dolphin or such-like. I expect the crack of the breaking fir stem boom, from which the line trails, will wake us from our dreams.

You may dream on board a whaler! dream at the wheel on such a day as this, or in the crow's nest, or sitting on one of the boats, for you are so cut off from the world of people 
who stop dreams-nurses, mothers, policemen and preachers. Alas, when you think of it, what genius has perhaps been nipped in the bud by the reprehensible habit of such wellmeaning people. Where would art, science and literature be to-day, we reflect, had dreaming not been discouraged by those who took charge of our tender days. Mercifully, with the advance of years, some of us learn to dodge these interruptions by going to sea, perhaps-where one may dream or follow out a train of thought, as it were, on the sly. For dreaming is following out a train of thought. Newton dreamed when he saw the apple fall. Mercifully he had got beyond the nursery governess stage, or his line of thought would have been nipped with: "Johnny, do wake up and come along now, don't dawdle there, what are you dreaming about?" Watt managed, on one occasion, to dream on the sly and watched a boiling kettle, and was it not either an Angle or a Saxon chief who dreamed and let cakes burn and so united the tribes of Southern Britain? Moral, when a small boy dreams over dessert you may morally rap him over the knuckles and he will eat his dessert, but you may have spoiled the greatest mathematical genius of our age.

So we muse or dream on ocean's bosom, and read a little of monastic times, since we are on the St Ebba, and disagree languidly with Froude's conclusions on Erasmus and Luther, and occasionally we cast an eye round the empty horizon. When suddenly, from starboard, come leaping dolphins, breaking the smooth monotony of the blue water. They sweep to our bows, we dive from bridge to bow, seize the hand harpoon, and all our little community wakens up and collects on our bows. Here they come to starboard! and we get all clear for a lunge at one-no easy matter as our sails are down, and we are doing eight knots by motor and roll heavily. Swish, swish-two leap near our bows and the writer nearly goes overboard in an effort to drive the young pine-tree and harpoon home, but it misses by an inch and the frightened dolphins dash astern and come up to port bow as if we were stationary, and so we pass the harpoon over to Henriksen. He waits his chance and drives home a very clever thrust and away goes the line and Henriksen very nearly after it, 
and all hands get on to the rope, spring at it like ferrets at a rabbit, active as cats, a heap of them tumbling aft along bulwarks till amidships somehow or other the kicking dolphin is lugged over the side amongst the struggling young sailors, and one with an axe chops its tail quiet, and in a second or two our first cetacean, the destroyer of lovely flying-fish, breathes no more.

I should think it must weigh about two hundred pounds. Henriksen takes the opportunity to demonstrate on a small scale the process of flensing the blubber according to precedent, and his own plan, so that some of our hands, new to whaling, may know what is wanted when we get hold of sperm or the large finner whales. It is rather like a demonstration by a surgeon to students, so rapid, but more of this method anon.

Yes, we find remains of exquisite flying-fish inside the mammal, and yet none of us have seen flying-fish about here ; are there then flying-fish here, but deep in the sea, or has the dolphin brought these from farther south ?

Alas! that the deck of the St Ebba should be stained with gore. The best of the meat we have cut off, two long strips down the back, perhaps thirty pounds each, and into vinegar and water they go, enough fresh meat for all hands for several days, and the oil of the spec or blubber will probably amount to a gallon-one gallon clear profit for our shareholder-one little drop of the vast ocean of whale oil we hope to collect some day for the furtherance of British industries, and the manufacture of margarine and olive oil in Paris, and the hundred and one other purposes for which whale oil is used.

We have not exactly broken the Sabbath, for though we are a British ship the crew is Norse and the Norwegian Sunday begins on Saturday afternoon and ends at two on Sunday.

Henriksen is rather pleased that we have a young crew for our new kind of ship and methods, as older men would be more difficult to train to our special needs.

We see a large steamer, French, Italian or Spanish, in tow of a Liverpool tug, grey-black funnel-white ship. We have seen only four craft since we left Belfast. 
P.S.-All hands have dolphin steak with fried onions for supper. It is not nearly so good as whale meat, but better than cormorant by miles-in fact, is quite palatable.

Who said that the romance of the sea has gone, that steam has driven it away? But that is not true; it is just as blue and full of fresh life and romance for all of us as it ever was. The new land or new port is just as new to me as it was to Romans or Carthaginians.

With every new type of vessel there comes a fresh aspect of the romance of the sea.

Our new type will revive or open a new chapter of sea life. No more black coal and smoke, but a clean, silent engine, petroleum plus sails; sails must come back ; look at our run down here, half sails, half motor ; the modern steam-whaler could not have done it, even the old sailing flyers could not either.

I think we could have converted any disbeliever in the romance of the sea if they'd have come aboard last night, when Henriksen and I had our southern charts out, studying the lonely islands away down there.

Visiting the islands of the world alone would fill books of sea romance; think of them, the thousands there are, some of them never visited. Those in the south of the Antarctic edge are described in the Admiralty books we have in such terse, dry words as these: "Of no interest geographically"; "Dangerous"; "Only of interest to sealers"! "Provisions for ship-wrecked crews were deposited by H.M. (? ship) in the year__" before the Flood! And they say: "There are only kergulen cabbages-a red root like a carrot" on one, and wild pigs on another; and on another the beach is covered with innumerable sea-elephants and penguins. Ghost of Robinson Crusoe, what else can a man want? Why, even these islands, the Azores, so close to home, how the prospect of seeing them fills us with eagerness! What will the hills be like, and the people, and the fruit, and the wine, and birds, and flowers, and fish ! We long to see them with the utmost impatience now that only a narrow strip of rough blue sea lies between us and them, to-night we may fetch its lights -to-morrow we will see the land in full sun for a certainty. 


\section{CHAPTER XVII}

NEW land, new to us, only a faint tint above the
horizon, but land it is, we know ; merely an outline
of faint soft blue-grey mountains over the sparkling morning sea.

All night we waited and watched for its lights, but not till daylight did we have the pleasure of seeing "land" ! Land rising out of the waters after even a week at sea is very gratifying, like food after hunger, like health after illness.

We have made a good land fall-we find ourselves heading straight to the centre of San Miguel, the largest island of the Azores group, within a few yards of the point we aimed at from Belfast; thanks to three skilled navigators, for we would have passed the islands miles to W. if we had not corrected compass by sun bearings, a procedure which demands very scientific knowledge of navigation.

So it is a case of a shave to-day, and getting out thin land clothing, with an occasional turn on deck between the operations to gloat on the blue hazy mountains.

We must bring a harpoon or two on deck to show our real character, for our queer craft, with its three guns forward, might make the Portuguese wonder what our intentions might be, especially as our full papers are being mailed out to Cape Town, and we must try to avoid any more red tape entanglements.

Gradually the hazy land is lit by the rising sun; some rays penetrate the veil of clouds that hangs over the mountains. We see greenish tints and white specks, and with the glasses make out that these are houses, apparently farms with a light and dark green tartan of fields and hedges round them.

Above the little fields are peaks with scrub or trees up to the clouds, below the cultivated land there is a steep coast 
like North Devon, covered with shrubs and cliffs, on which the sea sends up white shoots of foam.

As the sun rises the horizon becomes quickly bluesouthern blue, but towards the land the clouds still keep the light subdued over sea, hills, glens, and peaks. The sea has awakened but the land seems still to sleep. Dolphins come from seaward and welcome us, and alas, one poor fellow goes away blazed with a harpoon mark; he was very nearly becoming food for the poor human creatures on board St Ebba, but the harpoon drew !

This island, St Michael or San Miguel, is undoubtedly like Madeira, without quite such extremely rugged peaks.

We plan staying one day in port to overhaul the engine, and there to get a large-sized chart and local information about whales, then to patrol round the islands for a week, and, if whales are here, perhaps longer. If not, we go to Madeira, thence southwards with the advancing season.

How exquisite is the colouring of the white and pink houses against the green and violet of the hills. Now the sun is in full blaze and the sea intensely blue. We drop sail and fly a little white flag, with blue square in centre for a pilot, and swing in from the south to Ponta Delgada, and with the glass make out a pilot's flag and a six-oared grey pilot boat coming towards us over the little blue waves. The light grey longboat swings alongside; the crew are in pale blue uniforms, with dark blue berries, their faces brown or sallow, eyes, hair, and moustaches black as coal.

We got a slight shake after the pilot came aboard, we had stopped our engine for him to come alongside, and in trying to start again found it would not work. However, fifteen minutes of the little steam-engine we rigged up in Belfast brought up enough air pressure to start them. In the seven days' run from Belfast some fouling must have collected somewhere, possibly in the cylinders. The interval I put in usefully, talking to the pilot by means of some half-adozen words of Spanish and Portuguese and a good many English, plus sketch-book and pencil. With the last I find, after years of practice, a great deal can be expressed-half-adozen strokes gave an idea of the lie of the islands, and a dot 


\section{WHALING AND BEAR-HUNTING}

or two from the pilot showed where he knew whales are occasionally being killed by local shores' boats, so we feel that at last we are actually on fishing ground. His pilotage was very simple-he merely guided us to buoys, to which we made fast inside the breakwater.

\section{Ponta del Gada San Miguel Azores}

I have read about and seen many places generally recognised as being of a singular beauty and interest, but never of this jewel of a sea town. For an artist it is a dream of delight of the most delicate colours reflected in a sunny sea. The houses are such as one may see in Spain or Italy, white, or of all the lighter variations of shades of pinks, white, pale greens and cinnamons, and they are built up to the water's edge with only a margin of black volcanic rock showing between them and the sea. Most of them have their backs to the sea and have picturesque balconies and landing slips, but in the centre facing the harbour there is an open plaza with a church and tall square tower, and at its foot bosky round trees, dark green against the white walls, all reflected at the water's edge.

After being visited by port officials, doctors and Customs officer we went to the plaza in our boat, and a Captain Pickford, of a neighbouring vessel, who kindly had come on board to leave his card, as it were, said, as we swung into a gap in the white sea wall into a small inner harbour: "This is rather a pretty bit we are coming to "-and I looked, and my breath almost went with the unexpected beauty. The dock or basin we swung into in our boat is built of black stone whitewashed to the water's edge, with two flights of steps for people to land by. It is only about ninety yards square-houses of a slightly Venetian style on the land side rise from a double arcade, one arcade rising from the water with another inside it at a higher level, windows look out from the shaded inner arcade, white pillars of the arcades and arches support a house faced with blue tiles, with pointed windows and adjoining houses of pale pink and yellow tints. In the deep shadows of the alcoves and in the sun on the 
steps there were figures, men, women, and boys, mostly resting, some in brilliant colours, some in sombre tints; and these and white boats at their moorings were reflected in the waving dark ripples of the basin. For an artist I would say this hundred yards of light and shade and colour is worth all Venice.

Perhaps the colour of the light is the charm of the Azores; it is that Gulf Stream rich, colourful light that to me seems to increase south-westerly as you follow it, say from the west of Kirkcudbright to Spain, and westwards, till you come to the Saragossa Sea-a quality in the atmosphere that makes the night here redundant with colour and the day superlative.

Why do you not see quite such soft richness of colour in the air farther east? There is greater velvetyness of colour here in the Azores than in Madeira, or the west of Spain, or anywhere in the Mediterranean, or the Far East.

I could sit here for weeks, day and night, watching the changing effects, the queer parrot-coloured weathered boats, with their furled-up white cotton sails coming alongside the steps; the steps are greenish black volcanic stone, whitewashed, and the stone shows here and there, and the white is of infinite variety of tints and the sunlight is so soft and mellow that patches of colour, say a man's pink shirt, or a patch of emerald-green cloth, catch the eye with their soft intensity and your eye goes back and forwards revelling in the pleasure of the soft clash of battling colour, and tints.

The boats that come in from the blue are vivid in colouring, brilliant emerald, yellow, and scarlet, with thick white cotton sails. The largest are three-masted feluccas, long and narrow, with sails like swallows' wings. Each has a crew of at least eleven men and boys, with brown faces and black hair and beards. They go barefooted, and wear a peaked pointed knitted cap exactly the same as we have in the Fair Isle off Shetland; and each figure is a joy for ever of sunbitten, faded-coloured garments of many colours. Then think of these figures in the blue night moving noiselessly with bare feet, unloading short yellow planks for pineapple boxes in half electric, half moonlight, the velvety shadows 


\section{WHALING AND BEAR-HUNTING}

of the tropics and all the vivid colours of the day still distinct, but softened down to a mothlike texture, and the blue tiles on the house above the arches glittering in the moon's rays.

If you add to these sensations of colour, and the perfect stillness, the scent of pinewood planks and the perfume of pineapples you have an air to linger over, a delicious intoxication.

Both the people of Ponta Delgada and the town itself are very clean. Living in the Portuguese Hotel costs five shillings per day, with extremely good feeding-beef from oxen on the hills fed on wild geraniums, heath, and hydrangeas, and fish of many kinds.

I tried my trammel net for fish alongside in the bay. I set it with the second mate's help; it is forty fathoms

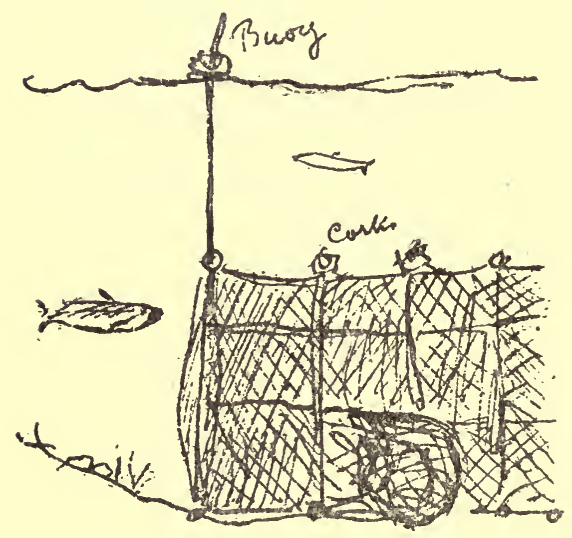
in length, and by midday there was quite a good catch of manycoloured bream, and those exquisite silvery fish, about the size and shape of a saucer, that are such excellent eating. The trammel net is quite new here, and is new to my Norwegian companions and to the natives. I find it of much use on our Berwickshire coast for supplying the house with fish. It consists of a wall, as it were, of fine net hung between two nets of very large mesh ; with corks on top and leads below. It can be set either standing on the bottom or hanging from the surface-the fish swim against it, make a bag of the fine net through a mesh of either of the big nets, and in this pocket they stay till you overhaul your net, possibly once a day.

Here we found a worm like one leg of a star-fish made such havoc with our captive fish in the net that we had to overhaul it every four hours or so. On the second evening I got three splendid fish, like salmon, of about six pounds each, 
with large silvery scales and small heads-cavallas, I hear them called.

Whatever their name may be, of one thing I am certain, they make splendid eating, and taste like small mahseer-of course everyone knows their taste!

I rigged up a bamboo rod, using cast of Loch Leven flies, with the wings cut off, with small pieces of sardine for bait. We made quite good baskets of young bonita, and tunny, and sardines : tunny fry, of course; a twoyear-old tunny

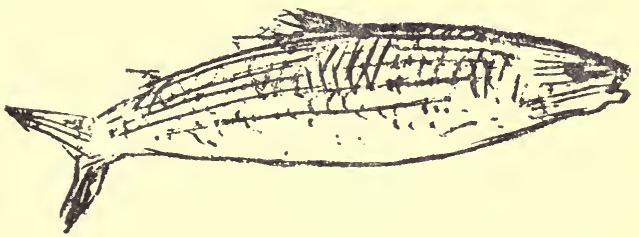
would snap strong salmon gut and a full-grown tunny takes a rope as thick as a stylo pen to pull it in; and lots of time. You can even take them on a tarpon line if you think life is too long.

A thing I could not understand about this small-game hunting was the way certain silvery fish eluded our efforts to catch them. Whilst other fish ate the finely chopped sardine meat we threw over, and young mackerel and herring, etc., calmly took our hooks baited with pieces of sardine, these flat silvery fish like saucers on edge almost at once grasped our idea-they eyed the bait and hook, sailed along the gut of the dropper, examining it closely, sailed up the gut of the cast and said : "No, no, we will take bait without a hook, but not this." I wonder why their perception should be so much keener than those of the other fish; probably none of them had ever seen a hook in their lives.

But this writing about small fry is "wandering from the point," as the cook said to the eel ; let us get back to whaling or at least to whale-hunting.

We are off to the west end of San Miguel to go round it and beat about the north side in search of the whales which everyone tells us are to be found there, and the view of glens and woods and fields bathed in sunshine under the cloudcapped hills is very sweetly refreshing. But luxurious rolling 
on the blue seas and all the sweet scenery hardly take away the unpleasing taste of last night. The engine overhaul was only finished last night, so we intended to up anchor this morning at daylight. Henriksen and I went ashore and waited for the Consul about some affairs at Robert's Café, a large, quiet café, with wide-open doors facing the sea. As we sat there rather silently, away in the velvety blue night, out to sea beyond the breakwater, several rockets rose and burst in a golden shower and we heard the continuous blast of a ship's horn making signals of distress. We jumped! so did the other two or three cigarette-smoking habitués of the cafe, and all got on to the sea-front, and the horn continued.

"That's a wreck," said Henriksen.

"Yes," said I.

"Wat we do ?" said Henriksen.

I paused for half-a-second-I couldn't advise-Henriksen is in command.

So I waited for this fraction of a second-it felt like a whole minute.

He thought and must have thought hard; for there are many things to put together in such a moment-owners' risks, personal risk, honour, risk of fines or imprisonment for leaving a Portuguese port without clearance, the chance of saving lives ; and last and least-salvage.

"Yes," said Henriksen, "we goes help-we's British ship!" and we turned and ran; he blew on his whistle as we ran, and our engineer and some of the crew, who had just come on shore and were entering a café along the promenade, recognised the whistle, and before we were up to them they were back into our boat and we jumped in and pulled off. We got on board, slipped our anchor and chain, marked with line and lifebelt for a buoy, got out side lights and started the engine, and were round the outer end of the breakwater within thirty minutes from the moment we left the café ! and I say we felt proud of St Ebba. The big town clock on the church was striking eleven P.M.

No other vessel in harbour was under steam so we congratulated ourselves on having a motor-engine and so being able to get under way so rapidly. 


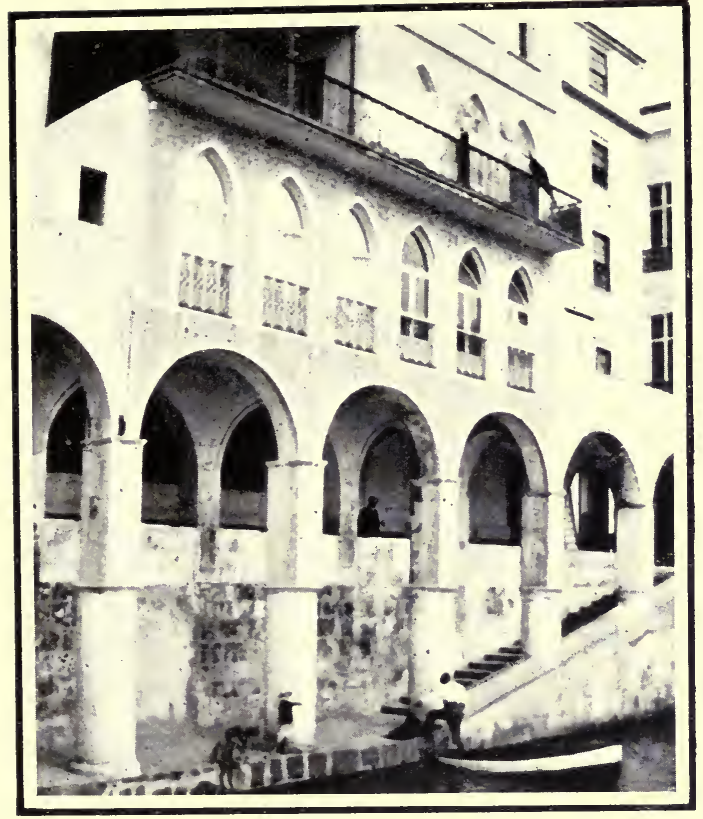

The Arcades at the Inner Harbour, Pon'ta Delgada, Azores

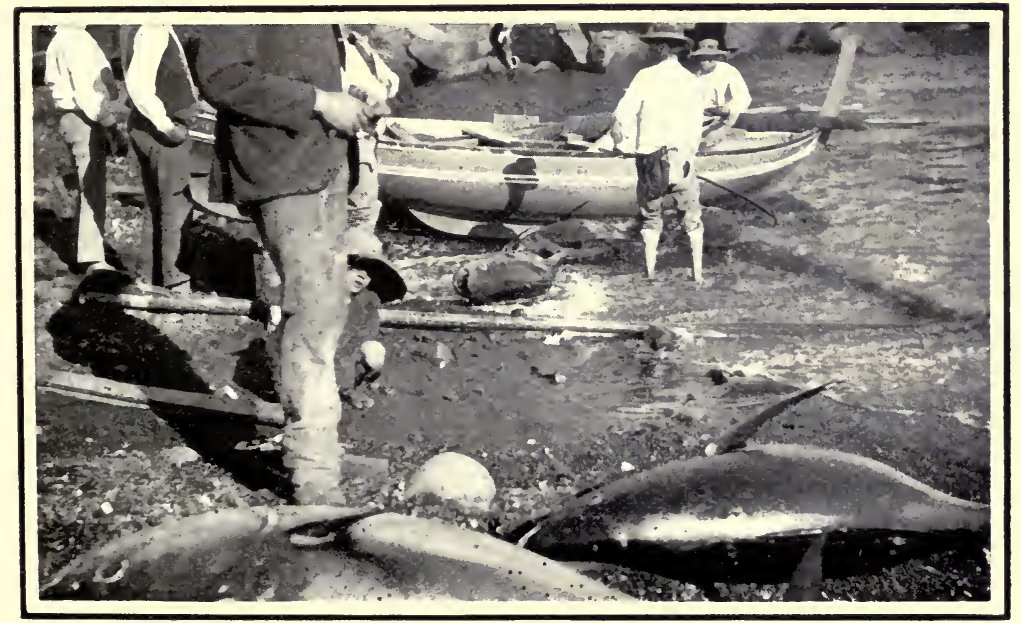

Tunny on the Beach at Madeira 

Till we came to the end of the breakwater, the distress foghorn signals continued. As we swung round it they ceased!

Out to sea for a mile or so we steered, looking vainly for liginis to the horizon and the S.W. and saw nothing. Then looked behind us, and there, on the most unlikely place in the world, were the lights of a ship, on the breakwater rocks, close to the fixed shore light!

Round we turned, going our best speed, and stopped when we had got as close as we thought advisable in the darkness, shoved over our flat dory and rowed off with a lantern in the bow.

The steamer was rolling gently on the rocks; we rowed close and the writer in the bow hailed them on board and offered a tow off into the harbour. The crew we could see, and they preserved silence for some time.

"Hullo!" we shouted. "On board there, were you sending up distress signals ?" A reluctant "Yes" and "Who are you ?" from the gloom on deck, where there was a little light that showed some Dutch courage going around. And we answered, and asked in turn: "Where's your skipper?"

"Below with owners."

"Well, tell him to speak" - pause- then came the skipper's "Hullo! what do you want ?"

"What do we want!" we repeat very angrily. "Weren't you firing rockets and blowing yourself inside out with distress signals?"

No answer.

"Were those distress signals?" we ask again, and there's a reluctant "Yes" and still another "What do you want and who are you?"

"We're St Ebba, whaler, motor ship, two hundred horsepower, and tons of cable, come to tow you off into harbour -half-an-hour will do it-there's an hour of flood yet and you can float that distance.

A long silence. . . . Then : "We don't want help-you've come along for salvage." I was dumbfounded.

I need not prolong the interview; the crew said they'd like to be taken off, they'd got their bags ready, but their skipper wouldn't let them. 


\section{WHALING AND BEAR-HUNTING}

The lamp showed her name on the stern in fresh gold letters - the B-enido, London-we knew a little about her, for a neighbouring steamer's engineer 'had been asked on board for engine trouble; and only a few hours before the rockets went up he'd been speaking to us about her. He said she was a new ship (two thousand tons?), Spanishowned with British captain, on her first voyage, engines made on Continent, hull in England, and she was all wrong.

She had left the harbour only a few hours before she was wrecked. The skipper set the course S.W., and a one-eyed nigger at the wheel steered N.E.

So we pulled back to the ship and told Henriksen of our abortive interview and he went off again with me and two men.

It would be pretty hard to put into words our very natural keenness and the wrath at the unaccountable apathy of the British captain of the Spanish-owned ship. But the result of the second interview was the same as first. They were going to cling to the rocks-we were to mind our own business.

We thought we ought to stand by all night for the sake of the crew on board her, for I've seen a vessel go on to rocks in a similar position and lie comfortably till the tide turned, and when the water receded heel right over and go straight down in a second.

When daylight came her stern had sunk till the deck was level with the water and lighters were coming off to take some of her cargo. We could have towed her off at first without much trouble and long before her plates were seriously damaged by the continuous rolling that followed and the falling of the tide. 


\section{CHAPTER XVIII}

O we left our wreck, meditating on the ways of a wicked world, and went on our own business to hunt round the south coast of San Miguel or St Michael (we call the island) to the eastwards.

Parts of the coast we pass are very like Madeira, which is said to be like a crumpled piece of paper lying on the sea. You calculate how many hours it would take to ride a mile as the crow flies, round the bays, over the tops and down the sides of the glens or ribieras.

What lovely places there are to ride or drive to on the

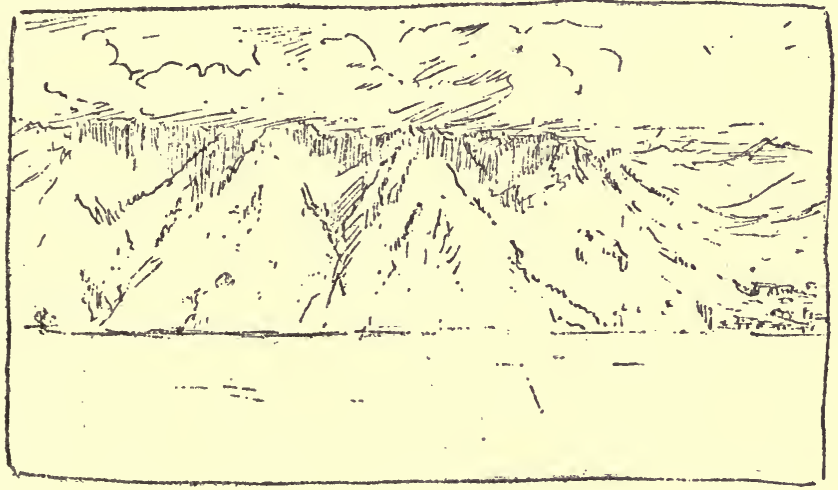

island, between pine-trees, heath and hedges of hydrangea. There is one road where you can drive continuously for twenty-one miles, with hedges of hydrangeas in full bloom on either side.

Whilst we go whaling, keeping a bright look-out for sperm, I must try to remember some of the inland charms and the show places of the island, such as the Seven Cities, an inexplicable name for two lakes and woods in a crater's valley, and the Hot Volcanic Springs in another valley which cure all ills. I would like to remember the low two-storeyed houses and narrow sheets of Delgada pink and white or pale 


\section{WHALING AND BEAR-HUNTING}

blue, and the green balconies and red-tiled eaves showing against a narrow belt of blue sky. The rooms or cellars of the ground floor are arched and the narrow footway is made of a mosaic of round pebbles and quartz. There is a quiet mystery in these narrow lanes in the hot midday, when the green shutters are closed, and more mystery again at night when all the blinds are open and there is lamplight and faint music from mandoline and guitar.

The shops of Ponta Delgada are in these arched caves

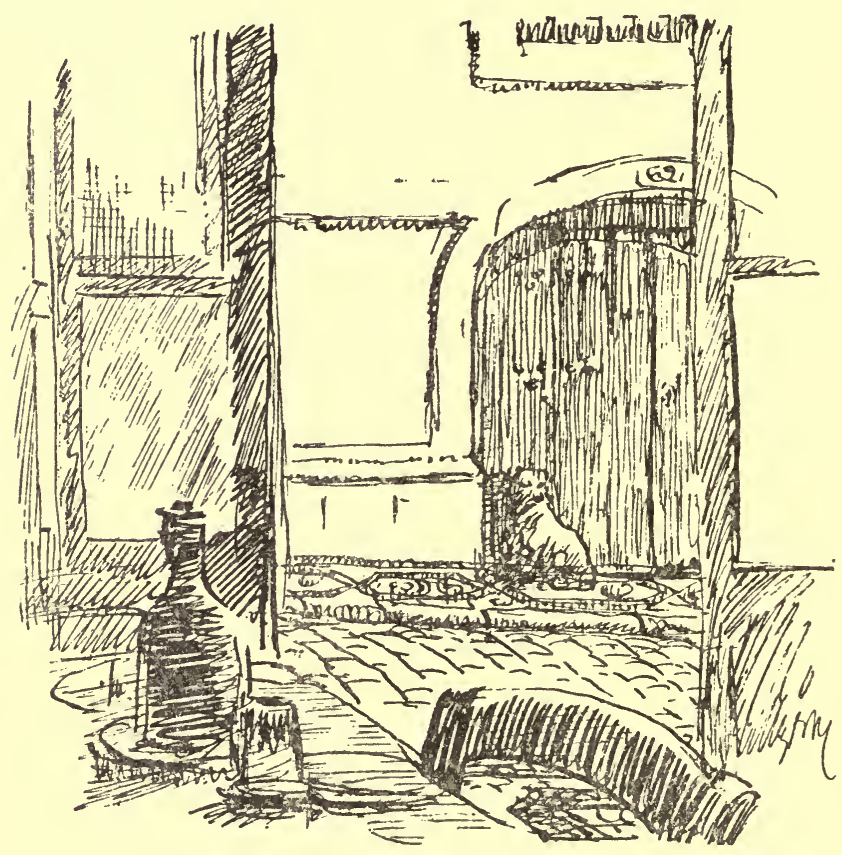

which support the dwelling-houses and balconies, and they have no signboards! If you wish to find a shoemaker you must walk looking into these caves. Ah yes! I've seen one signboard, a scarlet swinging hand representing a lady's glove-now that's worth remembering. Find that and keep it to starboard, till right abeam, then swing to port and you will find on your left a cave-topped restaurant, the Atlantico, clean and cool it is, with walls painted delicate green. There are six little tables in the front part, a desk and an arched 
hatch behind, at which lolls the cook, a jovial sort of unshaved burly pirate, with, of course, a cigarette, but veritably a chef. And behind the desk, sometimes for a moment or two, is your host, a highly polished Sancho Panza; here is a jotting of him. He speaks a little French and gives you provender fit for the gods. I mention this place as cafés are rare things here, for the people as a rule feed at home.

Into this haven I came one night after the spell at sea of salt beef and margarine, and who can tell the contrasting charm

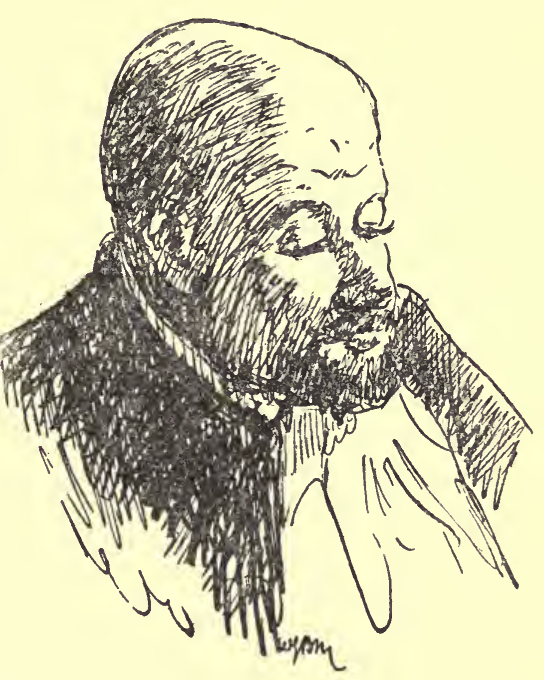
of the crisp rolls and real butter and vino tinto! And as I rested and made furtive notes of the patron there came music from above or some room near-a piano of early nineteenth century - or was it a spinet or guitar playing the air of one of Moore's melodies.

" All that's bright must fade, the brightest still the fleetest, All that's sweet was made but to be lost when sweetest."'

It is used in Indian as a bearer's tune, and these are what I can recall of the words from the long ago. It's a sweet air and surely the words are distressful enough to make a young man sad, and an old man smile. I wonder what Portuguese words the fair (I mean dark) beauty next the Atlantico put to the air-I must call again. Some of these native women are very pretty, but they are much more guarded in the use of their eyes than are their Spanish cousins. There's a queer dress some of them, mostly the seniors, wear out-of-doors; when they come out, which is very seldom. Here is a jotting of it on the next page- it is of dark blue cloth. The younger generation wear rather neat 
up-to-date French dresses, but you see very few townswomen, they stay indoors, but many countrywomen come into the town in the daytime and a group of them sitting with baskets and fruit, with their vivid kerchiefs and

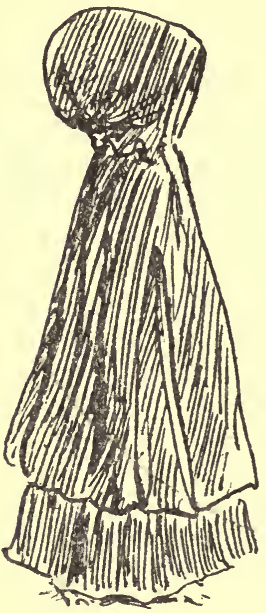
shawls, make a colour, light, and shade, enough to make a painter's heart leap with joy.

We hunted round the east end of San Miguel and saw dolphins and some very small whales.

Then we went north and chased some small whales, one, the biggest, almost white. It was getting late, the sun setting behind the cloud-capped island, still we stood by the guns-skipper, first mate and the writer each at his gun, ready for a chance shot. These little whales move too quickly out and into the water to give a fair shot.

The little excitement helped to raise our spirits from the damping disappointment of the wreck. We now drift, and expect the light wind to take us down to some shallower soundings which we see on the chart several miles south and east of San Miguel, where we hope to find whales; for they are in the habit of frequenting the edges of "banks," when say two or three hundred fathoms change into a thousand fathoms.

The way of a man with a maid is perhaps a simple problem compared to the ways of whales. Who can tell how they guide their course, year after year, past the same points, travelling, for instance, off the Shetlands always N.E. along, you may say, a definite line.

Our plan for next week or so is to beat up the seas north of San Miguel, going about twelve miles, spying six miles on either side, then taking a right-angle course for other twelve or twenty-four miles, and so spying a large tract of sea, and by this simple means we can keep our position easily ; and we keep the ordinary four hours' watch ; later, when we get whales, "if" I should say, we will have all 
hands on deck all day, and only a watchman on deck at night to attend to the steam cookers-but when will that be? There is a new moon to-night and I turned some silver leiras and a sixpence in my pocket, and will play the pipesthey may bring us whales--bagpipes make both salmon and pike take vigorously; I can bring witnesses to this! and they have, beyond doubt, an effect on the wind.

... An exquisite morning; at eight o'clock comfortably hot-wind westerly and we paddle away east from San Miguel. The island is getting low now on the horizon, but we still see a glimpse of sun on its highest land beneath the shadow of the great cloud cap-a glimpse of fields and faint white specks for cottages. Yes, my first impression seems still to hold-a land you could live and love in, with such exquisite sunny soothing fresh air; from the little glimpse we had of its people such ideas seem tenable.

We drifted all night, with riding light, taking things easy. Our busy time is still to come, perhaps that bank we are drifting towards, out of reach of shore whaling-boats, may show us some plunder or profit per cent., and if it doesn't, well, we have other islands to discover and circumnavigate. "Discover" is the word I want. Once, long ago, the writer, with others, discovered new vistas of land and mountain, uninhabited grand mountains and glaciers in seas of tabletopped bergs of huge proportions, and undoubtedly the sensation was not to be forgotten; but praise be, a new land to the writer, with new people to him, and new habits and customs, is still of the greatest fascination, even though it has been known, like these Azores, for six centuries.

I question if Columbus enjoyed the first sight of the Norse Vinland any more than we shall enjoy the sight of the next island we come to of this archipelago of nine islands.

Fayal, for instance, and Pico-we have seen post cards of both, and each looks perfectly charmingly fascinating. Pico must be like Fusian, the Japanese peak.

Truly this sea, between the Azores and Africa, is well called, by old shell-backs and South Spainers, the Ladies' Gulf-most days fine, and blue, and then a tempest. The 


\section{WHALING AND BEAR-HUNTING}

rocks Formigas we aim at lie between San Miguel and Santa Maria to the south-east. But the wind now blows hard and the sea runs too high, so we turn and pound back to patrol the north side of San Miguel, where we will get a little slant of shelter from the land.

As the wind is westerly we cannot help recalling what we call " our wreck" the B-_-enido, on the rocks of the breakwater, for a south-westerly wind is just what is needed to pound her into scrap iron; whereas she might have been floating to-day in port if she had accepted our polite offer of a tow.

A turtle is all we have seen this morning, and we have been looking out hard-one man in the crow's nest on the foremast, and two on the bridge, and the writer in main rigging. The turtle was a browny yellow patch near the surface of the deep blue sea. We turned back to try and harpoon it, but it had gone down.

Though there is little life to see in ocean to-day it is pleasant enough sitting up in the shrouds watching the horizon, or sometimes casting an eye down to see St Ebba dip her bows under, and the burst of white spray that have made us again put covers over our three guns. The movement, sitting on the shrouds as we buck into the short sea, is rather like a side-saddle canter on a beamy carriage horse.

Before sundown, the wind keeping hard, we close in with the land, getting into smoother water. As we go some small whales appear, about fifteen or twenty feet long, and keep under our bows, and nearly give us a chance of putting in a small harpoon. They were whitish on back, with under side dark, marked along the sides with criss-cross pattern, as if slashes of a knife had been made through the dark skin.

There is a South Atlantic whale with its back marked in somewhat similar manner. I have seen a few in the Weddell Sea, amongst the Antarctic ice. Ziphius novae Zealandica,possibly this is the same, which would give a wide distribution.

I think this is as elaborate an impression as I dare to make without drawing on what I think it might be like, or faking, to use the artist's term. But they kept so much under water, and only came to the top for such a rapid breathing- 
space, and it was so rough that we did not blow any powder -better luck next time.

Two and a half miles off shore we heave to, lash the wheel, and drift slowly out to sea and close our eyes for a little, they are sore with gazing across the blue in salt spray, wind and glare of sun.

Three little white and pink towns above a coast of cliff are to windward, and a little more to the south-west there is the volcanic mountain of the Seven Cities, with the lakes in its crater, a place of great beauty but suggestive of Martinique, especially so to-night, as there is an off-shore wind blowing from the south and an immense pall of cloud flowing over it and us, shadowing the little towns at its base, Ribiera Grande, Calhetas Morro des Capellas, and our little selves out at sea.

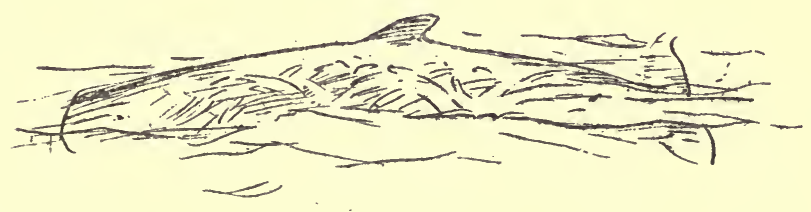




\section{CHAPTER XIX}

T SEE I have gushed a little about the blue sea in the last chapter. This begins with storm, and gale, and 1 courage running into water in the grip of the elements.

Just now we are rolling in a loppy swell, high and irregular, but there's no wind to speak of. We are right round to W. and S. of St Michael and we see the island faintly to north to windward, distant some eight miles; it gives us shelter from the remains of a north-east gale that sprang up last night, and is only now dying away this afternoon.

Between the time it rose and fell we had too much time to think and little enough to act.

As I said over the page, we were last night drifting north, with a land wind from the island south of us; and at about ten, I and Captain Henriksen had turned in, planning and hoping for fine weather and whales in the morning ; at onefifteen I heard the whistle in his cabin blown from the bridge and guessed a change had come- the wind had gone roundhe was on deck at once, I waited a little and followed. And sure enough, without the least warning, the wind had gone right round to north-east and was rapidly rising, driving us towards these beautiful villages and cliffs and bay and volcanic mountain dead to leeward in pitch dark. Only the village lights and a small shore light could we see, bidding us anything but a welcome.

The half-hour we spent drifting towards the cliffs, speculating whether our so far rather tricky motor would start, was memorable. The waves rapidly grew large and fierce in their sweep, the phosphorescent crests in the blackness repeated the lines of lights of the villages.

... Fortunately the engine started all right, or these notes would have to have been continued about mermaids under the surf; I suppose all hands knew that if the engine 
didn't start we would be drowned under the steep cliffs. They have failed us once or twice lately, but this time Hansen did his possible, and poked about, heating the cylinders with the hand furnace, whilst we grew a little cold drifting to the surf and rocks. In half-an-hour he turned on the air and they went off with a welcome clash. All hands must have felt as I did, a great sense of relief when they started, but there wasn't time to speak. The writer took the wheel, whilst Henriksen and his brother made a rapid note in the cabin of the course and position, and we swung round into the rapidly rising sea, heading north to get weathering to round the mountainous west end of the island, and plugged into wind and sea, completely smothering ourselves in foam. The writer, struggling at the wheel on the bridge, had an unconscious impression of the crew below busied in making fast the main-hatch, and stowing away movable objects as best they could in the darkness, and seas that broke over us in wide white bursts, sometimes hiding everything from the bridge except the upper part of our foremast, its shrouds standing out black above the foam, through which we saw faintly the gleam of the galley ports.

What wild waves broke over us, leaving our deck full of seething foam, with balls of light running about in the form of lumps of phosphorus. The north-east wind and rain tearing past was a little cold, and got down one's back, but every slop of sea on our faces was almost alarmingly hot in contrast to the wind.

It seems to me that a higher, quicker sea rises in these warm latitudes than in the colder northern or southern high latitudes, in the same time and with same force of wind. Possibly the greater density of the cold water may account for this.

Not till four-thirty did we make our weathering, and got clear of the island, and safe from what seemed at first to be quite probable destruction.

By six-thirty A.M. we were past the light on the west end of San Miguel, at least we believed we were-it was not visible; being at an elevation of three hundred feet, it was, of course, obscured by the low clouds; it is no use putting lighthouses 
very high, as witness Sumburgh Head, south of Shetland; I have been within two miles of it in clear water, and it was invisible in the clouds above, and we only heard its bray!

Then our guiding angel, to play with us, stopped our engine. But in spite of her, we got it to go again, and crept into the lee of San Miguel, on one or two groggy cylinders, and rolled about in the downpour of rain, and the poor engineers are now sweating again to get even one cylinder to take us back to Delgada, where we will have an overhaul; and Henriksen and I, poring over our sodden chart and the wellwashed cabin amongst sea-boots and oilskins cast aside this morning, decide that the weather of the Azores is not suited for whaling at this time of the year. If there were harbours or bays or lochs such as we have in Shetland we would stick here, but long, black nights to windward of islands, with strong gales starting from anywhere, and only one day in five smooth enough for even our St Ebba to whale in, "is not good enough."

Now the engine is going; bravo, stick to it! Very, very slowly and gingerly-with three cylinders-we crawl away with a fearful roll to Delgada again.

But the day fades before we get opposite Ponta Delgada, a yellow sunset and rain clouds and cumuli to west, the pinpoint of light on W. of the island beginning to show, and another pin-point on Delgada about ten miles to windward, so we stop engines, hoist foresail, and drift, rolling very gently and quietly, waiting for dawn, and the local pilot's awakening; we could go into the breakwater ourselves, but his services are compulsory.

All is very quiet and peaceful to-night, and no references are made to last night. Sailors have nerves as well as other folk, and I daresay all on board will take a day or two to recover from the excitement and drenching, and the bitter, nauseating feeling of being up against one's end on a stormbeaten coast in black night. I have a curious feeling that even writing about such a recent and painful situation is almost indelicate. To put in time Henriksen draws on his recollection of killers or grampuses attacking a whale, and I help it with what I have seen of a similar incident. He saw 
this particular incident off Korea ; I have seen several whales being attacked both in northern and southern latitudes amongst the Antarctic ice ; in fact, I once could have jumped on to the back of one as it rose right under our stern and gave a huge blast or sigh, with a pack of these black-and-white marauders surrounding it !

That was a night in the Antarctic worth recalling. It was a still day, far inside the pack ice. I remember being lost in admiration of the quiet blue lanes of water, blue and violet, and the many pearl-like tints of the ice, and as I looked northerly I was astonished to see penguins jumping on to

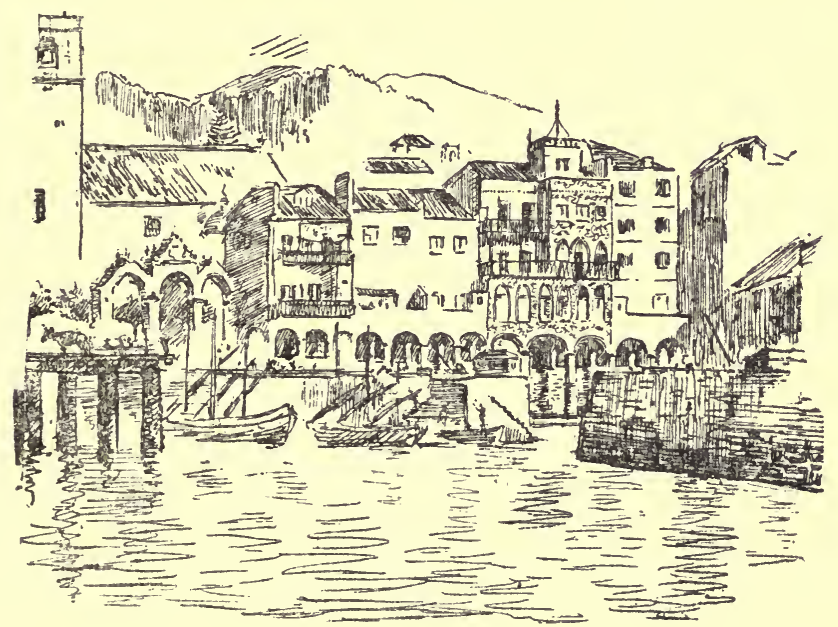

the floe ice in a great hurry, down the sides of one of these long lanes. Penguins do not show themselves in the water, they suddenly leap out like trout and disappear. In this case they remained on the ice-floes, skedaddling to their centres in an agitated manner. Then the cause of the emeute appeared - there were hurried blasts from two whales coming down the lane towards us, and behind them the splashing of a pack of black-and-white killers. On they came, the penguins popping on to the ice edges, jumping two or three feet clear of water, and I had time to get into our mizen rigging and get a fine view of the first whale, a hundred feet long, as he sailed under our keel. The next one 


\section{WHALING AND BEAR-HUNTING}

rose to blow immediately under our counter, and anyone standing at our wheel could have jumped on its back.

I did not see the end of the chase. I expect the whales were making a flight into tightly packed ice, under which they could possibly go to greater distance than the killers without breathing - at least that is our explanation of their manœuvre.

These, of course, were finner whales, we were hunting for Right whales, the difference between the two in shape, etc., I have referred to at the beginning of this book.

Delgada again. Here are some oddments in this chapter. I notice I put down in my log that I suffer from sore feetsunburned insteps-and see Portuguese doctor, you go barefooted on such boats as ours in sub-tropics, and this was the result.

I met the captain of our wreck, the B-enido, a Welsh-

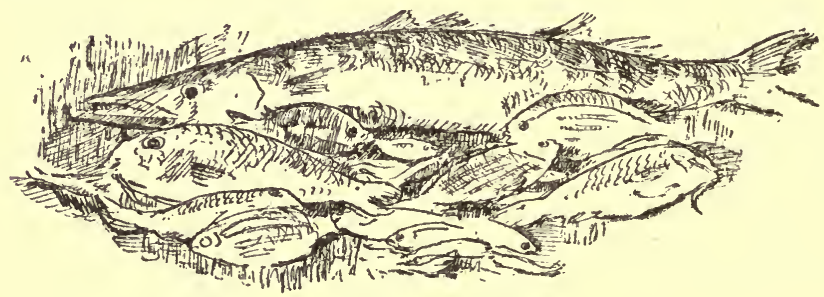

man, in a tight place, and almost as silent on shore as on his ship, but I felt sorry for him.

The engines were thoroughly overhauled, and favourable was the verdict of the engineers on them-which was satisfactory for all hands ; the first engineer, a Swede, would like to take three hundred shares in our Company if he could get them. He is so confident about our engine, possibly he may more correctly be described as sanguine.

We entertained British Consul Rumble to dinner, a return compliment for several courtesies from him, to-night at eight P.M., and he is just departing ; my feet are very sore. We caught about fifteen good fish in the trammel-net, and a 
lot of sardines in a fine bag-net which I bought here for the ship ; it is spread from an iron ring and catches a few of the more foolish fish ; we also caught a ray, or skate, yesterday, about eight feet in width, in the trammel-net. Some people would venture to eat it, we did not, it was so black and ugly.

Our engineers and officers have worked very hard all week, overhauling the engine, taking it all to pieces, reassembling it, and working till one o'clock each night. So we promised them a jaunt on shore to the Seven Cities, the wonder of the island.

So this Sunday morning I saw six of our crew off for a drive over the island, the captain on the box, a burly figure compared to the little Portuguese driver beside him, two engineers, two mates, and the steward, all in neat Sunday dress, inside an open antediluvian barouche held together with string, the springs down on the axles, and a huge heap of ragged maize tied behind to feed the scarecrow horses. I was to have gone with them but there was not room, and I found it impossible to get more than the one machine on this Sabbath morn. All the rest were laid up or had gone off with Sunday parties. To get the one, I'd to run from pillar to post, and use soft, persuasive language, and listen to infinite reasons for there being no possibility of getting a trap at all.

But it was worth the trouble of hunting for the carriage to see my six good shipmates drive off in great form with a crack of the whip, rumbling over the cobbles, and waving hats to the writer, who suddenly felt somewhat lonely.

But to-day, Monday, there's nothing to keep me on board, I have done my painful duty; I have drawn in best style our registered number on our sails above reef points, according to act, and on tin plates for stencils to paint the same on St Ebba's side to port and starboard.

On our fore quarter, there is now $\mathbf{L ~} \mathbf{H}$, which signifies Leith, and 256, each letter the thickness-number of inches and fraction of an inch-ordered by the Board of Trade, with the distance between letters and figures all according to the law of the Medes and Persians.

It went decidedly against the grain to stamp our yacht- 
like craft with such vulgar herring-fisher's symbols. And putting black paint by mistake on a white sail is enough to make a yachtsman weep. What benefit can be derived by anyone by the above procedure I have yet to learn.

So to-day I also must go and see these Seven Cities. No one knows the reason for the name; my messmates tell me it is a volcanic valley almost circular, with a double lake at the bottom, and round the lakes are smaller extinct volcanoes covered with foliage.

Arming ourselves, therefore, with a sandwich of goodly proportions, and a bottle of vino tinto from our friend Sancho at the Atlantico café, we sallied forth in solitary state in an

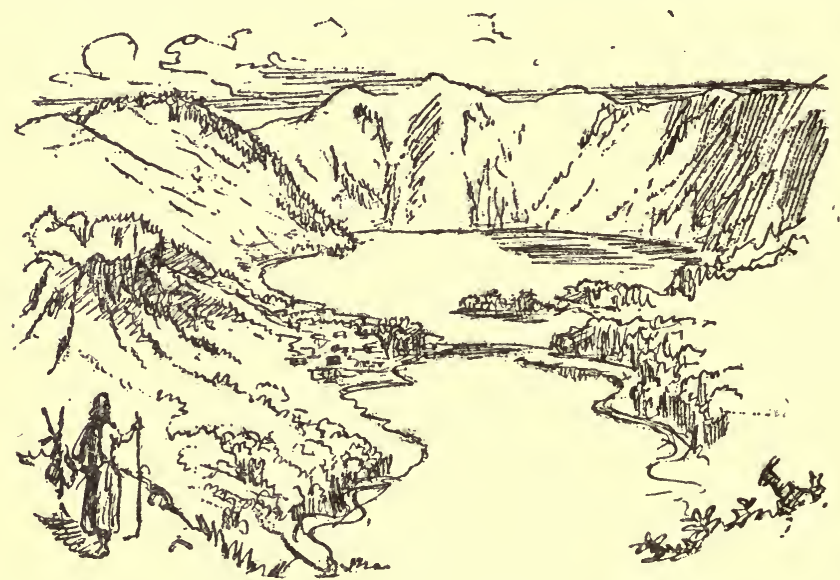

old brougham, one artist whaler, three horses and a Portuguese driver, and a bundle of maize straws astern, and drove and drove, always uphill, through little whitewashed villages and narrow lanes, between low stone walls, and crops of Indian corn, rather dry-looking, with pumpkins and gourds on the stubbles; past many farm carts, loaded with golden maize or pumpkins, and with groaning, squeaking wooden discs for wheels, till high up we came to little grass fields and hedges of bramble, and loose stone dykes with bracken and canes on them, and where the air was fresh as in Perthshire, and there were very wide views of the blue Atlantic. The drive felt long, but a sketch-book going, helped to make the road feel tolerable, but it was quite an hour and a half before 


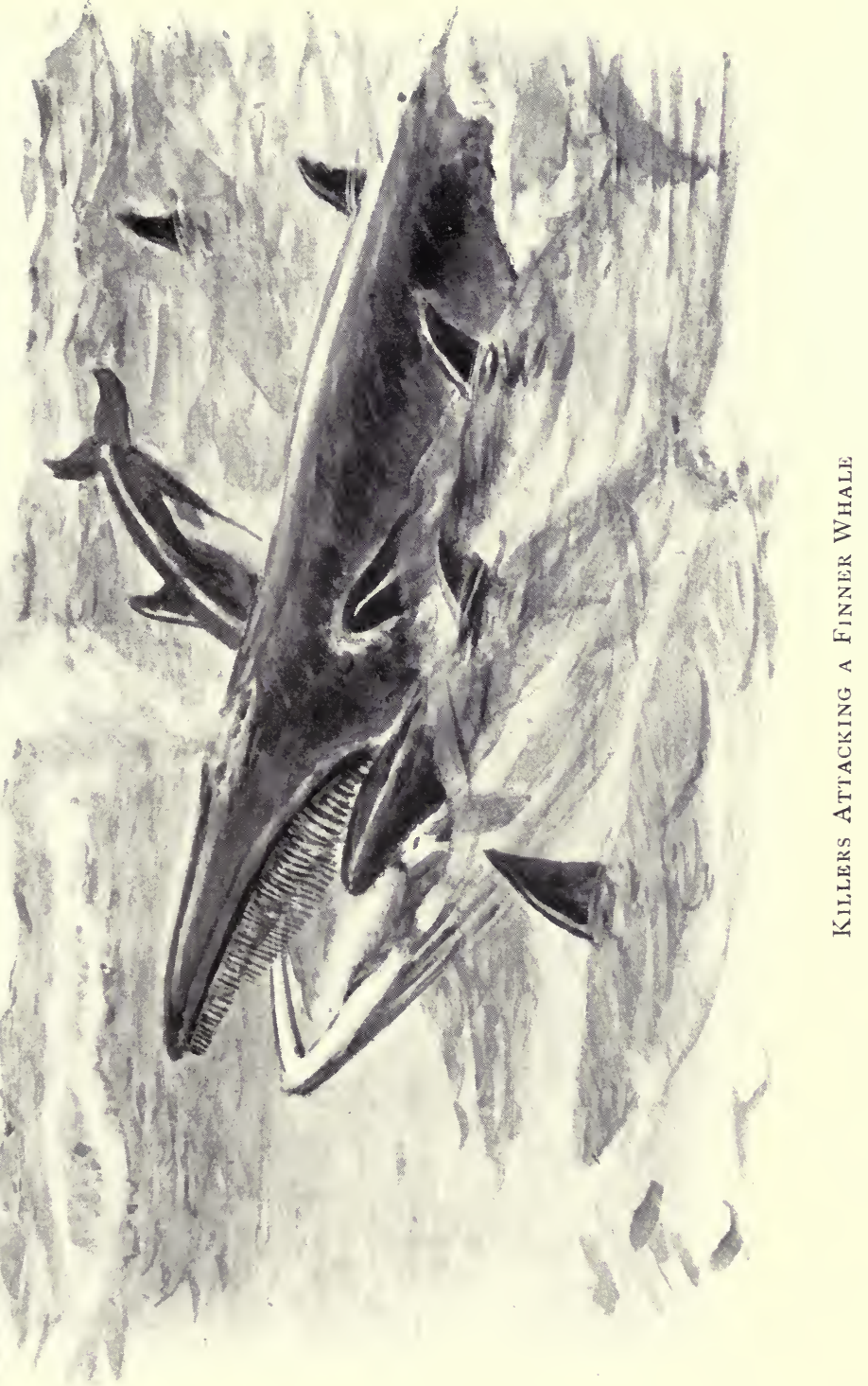



we came to our change place, Lomba da Cruze, and mounted a stirrupless pack-saddle on a donkey, and began an hour's uphill climb through cuttings of lava deposit, overhung with brambles, many laurels, heath and ferns.

Possibly this stylo sketch in sketch-book may be a sufficient description of the Seven Cities. Imagine two green absinthcoloured lakes, green foliage, and a few white houses at the bottom of a crater; with this sketch you have the scene, and you can fancy the charm of the fresh, keen air up the mountains combined with Sancho's great ham sandwich and tinto, but heaven fend the reader from the pain of a wooden saddle on a donkey riding down such a hill again.

The road home was wearisome to a degree, hundreds of local squires or farmers, and everyone lifting hats, but why? Who knows? The effort to respond was quite ridiculous. Someone should invent an automatic hat-lifter for royalties, Norwegians, and natives of the Azores. Groups of women were on either side of the road shelling yellow maize, sitting like Indians ; and at last and at length we got into Delgada, having had more than enough of cultivated maize lanes and lava dykes.

Then to Portuguese shipping agents and to business accounts, not a pleasing part of whaling. It is difficult to settle our affairs, on leaving port. For instance, the harbour trustees, or whatever they are called here, wanted to charge for the morning's incoming pilotage after we had gone out to save a wreck, but we barred that. "You old mens sleeps here ashore," said Henriksen. "We's go out, slips anchor —dark night-risks our ship, you charges us! might have been Titanic and we save thousands' lives. You say you haves many tow-boats! why nones go out? What about insurance, heh ?" They quietly dropped the subject.

But now it's time to go and put aside the above reflections and disappointments so far; we have hope, and months, possibly years, and certainly long seas in front of us, to gain or to lose in.

So we up anchor at night with a light air from the east, and several weeks' sailing in front of us to Madeira and Cape Town, and whales on the road, we hope. 


\section{CHAPTER XX}

DAREWELL, Ponta Delgada, with your pretty streets 4 perfumed with fir planks and pine-apples; farewell, 1 San Miguel. How sweetly the delicate tints of your capital-pale pink and blue-show in this early sunlight.

Your great clock on the white campanile marks six A.M. and the sunlight glitters already on the blue tiles above the arches of the inner harbour. That is the place for an artist who would paint in highest toned water-colours-flowers, fruit, wine skins, white walls, and blue sea. I will grant you all this, San Miguel, but there's a grim side to your islandcliffs and a lee-shore on a black night, and I seem to recall a wreck and rockets, distress signals all a fraud, and then there are those moonlike craters, your beauty spots. You and the Inferno, Saint Michael, seem to be somewhat neighbourly. And your people we recall, how kind to the stranger, a few of them, dark-haired girls in white dresses on green balconies seemed pretty enough, but in the country how close they seem to the soil, worn and aged, one good-looking among a thousand sad women, one pretty child in threadbare rags healthy, amongst so many who looked pinched and hungry.

No, we do not drop tears at leaving you ; but think hopefully of Madeira and Funchal to the S.E., where we may meet white people of our own race, and where I have seen whales; and perhaps we may have a day or two in the boats, off shore twenty miles, in the heat and blue rollers, fishing for tunny. A two-hundred-pounder, with the hard line cutting grooves in the gunwale as it whizzes into the depths, is good hunting.

I pen this farewell to the island in my bunk, looking out at the port, determined not to go on deck and see any more departures-that hurried one in the night watches to save a wreck was quite satisfying, so "we" doze and let the 
town and the island go by, and think of Madeira and the Cape Verde, and hope that some day soon our little expedition will begin to pay, and try to forget that so far we have only incurred expenses-five shillings here and five pounds there-pilotage and telegrams, and a thousand trifles that mount up alarmingly without one penny of return.

Thus musing somewhat sadly, and all the time listening to the beat of our engines, I notice they suddenly go a little slow, and a tide of depression that even the joy of leaving port will not quite raise, floods my spirits. Yes, they are dead slow now-something wrong again !-and I harden my heart and turn out and find we are heading back for the distant island-more weeks of detention, I can see. Butwhat is this-everyone is intently looking forward with craned necks!

Great Scott! There are whales-Sperm-as you live! At last-whales! One little blast on the calm grey ocean a mile away, then another, eight or nine. Nine times several hundred pounds sterling rolling round, each about a mile apart. Are we really in our senses-are we really to strike oil ? Heaven be praised-it is not the engine-it is all right.

We're after one.

Henriksen made a bee-line down to his cabin, got out powder and had the harpoon-gun loaded and ready in two shakes.

It is difficult to write about the day now, we are tired, the work has been great and our first whale worth, say, some hundred pounds, enough to cover our outward-bound expenses; it seems hardly believable.

It is true we have only one of these sperm. We could, I believe, have killed several, but for a completely new crew ${ }^{1}$ at whaling; we thought one would be enough for us. It is a bit awkward with one fish running a line, to tackle a second that perhaps goes in the opposite direction, and the flensing at sea for such a small crew is such a big work that we simply stuck to the one.

\footnotetext{
1 Only a few of our men have done bottle-nose whaling, but that is the same thing on a small scale.
} 
We chased it for hours; there is no good in chasing one and then rushing off to the next that appears; by a fluke you might strike across the stranger's course and get him on the rise, but the best plan is to study the movements of the whale of your choice, and by judiciously following it learn its movements so as to cut across its course and get in your harpoon at the right time.

It is difficult to describe the intense excitement of chasing whales, and the more so when your interest in it is even more than the hunting-when you have shares to make profit on, for friends interested in the bag.

At about seven-thirty we saw the whales, and by nine we had been three times almost within harpooning distance, say within forty yards, when always the whale "tailed up," and took his final dive. A whale comes to the surface, blows and takes in breath, several times, just going below surface between each blast. After it feels refreshed it goes below on its business for a dive of, say, twenty minutes or half-anhour, and may appear any distance from the spot it went down at. In this last dive it raises the after part of its body with a slow elevation, a sort of sad farewell to the hunter. Certain whales, such as the sperm and narwhal, and Right whales, lift the whole tail out, but others, such as the finners we hunt off Shetland, only show the ridge in front of the tail ; and seldom show their tails or flukes until they are harpooned.

One thing that comforted us greatly was that we knew from this whale's movements that though he avoided our treading on his heels, as it were, he was never scared or gallied by our engine or propeller's beat.

It would take volumes to describe the different ways of each kind of whale. The sperm whale usually feeds in something of a circle, so you keep cruising round the inside of the circle.

For hours we chased, very seldom speaking, eating brown bread, and drinking coffee, standing on deck, sticking to the neighbourhood of our first acquaintance, balancing the prospects of our expedition's failure or sucecss on the way this one whale took our approach. Sceptics had told us the beat of our motor would frighten a whale more than 


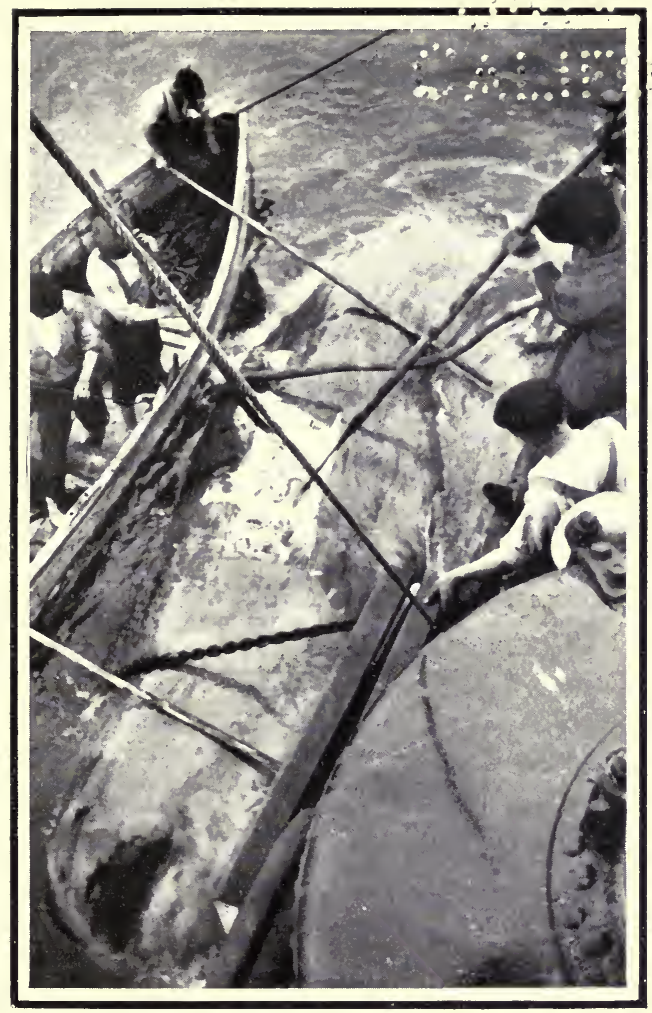

Cutting with a Spade into the Case or Head of a Cachalot Whale

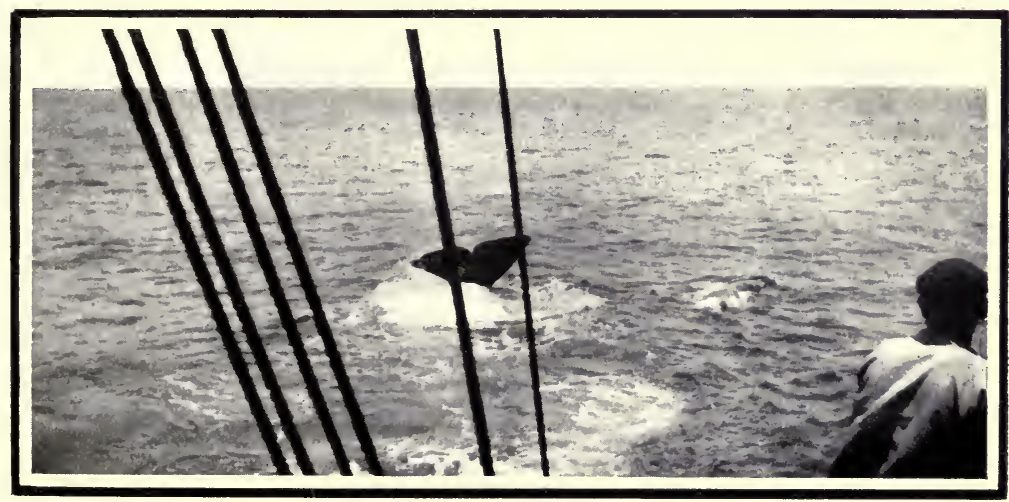

The Tall of a Sperm or Cachalor Whale Sounding 

the slower revolving screw of the steam-whaler; we play our one card that it will not, so to-day our anxiety can be understood.

There was too much at stake on this occasion for the writer to do the harpooning, so Henriksen took the gun and harpoon. The actual firing and hitting a whale any good pistolshot can do. But manœuvring the vessel, stalking the whale, as it were, needs a good deal of experience, and it goes without saying one must have perfect sea-legs, indeed, that is perhaps the greatest difficulty. It takes a great deal of experience to be unconscious, when there is a roll on, of

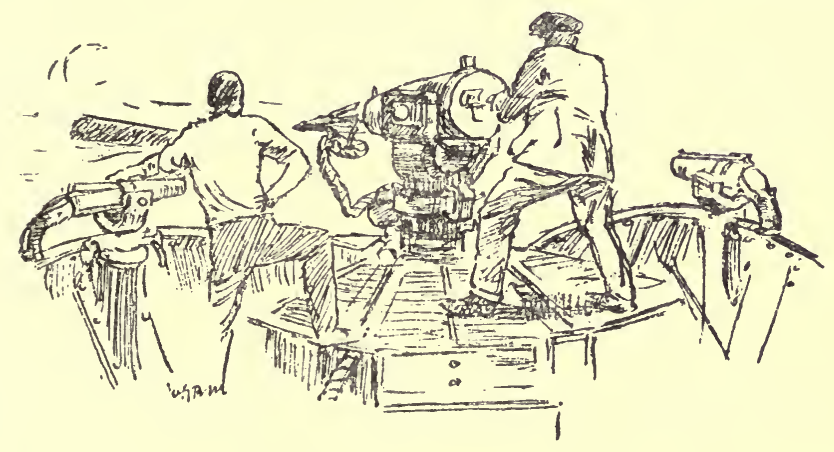

any effort to balance oneself, which is, of course, absolutely essential for a successful shot.

At last the grey, blunt-headed whale rose almost in front of us a little to starboard, blew his blast and went under for a few yards and rose again dead in front of our bow; higher and higher his back rose, then Bang!-and we were fast and the line rattling out.

That was a grand boom! and a straight shot. A great surge followed as the whale went down, and out went the five-inch rope-for but a short distance, though it was a heavy rope, spun for far more powerful prey than the sperm or cachalot, and we soon began to reel in, and the writer with a long lance ended the valuable animal's troubles.

I noticed, as the point of the lance went into the whale, that its silky grey skin was marked here and there with series of circles, something like Burmese writing magnified. I 
take these to be the marks from the suckers on the tentacles of the great cuttle-fish on which the sperm feeds, and here and there, over its great sides, were deeper scrawls-lightbrown-coloured lines on the greyish skin which may have been made by the cuttle-fishes' parrot-like beaks. Two of its companions came alongside it while it was still alive, and tried to help it by shouldering it away from us.

Had we only had a bay to tow these whales into we would have easily taken more, but we did not quite know how the Portuguese would have welcomed us had we towed their bodies back to Ponta Delgada after killing them, if not exactly at their own doors, still within sight of their town.

The big grey backs with their blunt noses looked intensely interesting when we first came amongst them-cruising about and puffing little forward jets of spray almost without the least regard to our presence.. . . .

We have waited several months for the sight, and I am inclined to think we feel repaid-that is, looking at the matter merely as hunting.

. . . Somehow I feel at a loss here how to describe the accumulation of feelings at the end of the long waiting and planning. We feel we are right on the high road to success, our engine worked perfectly, our vessel was apparently calculated to a nicety to approach and kill whales, and to keep the sea almost indefinitely.

Big finner whaling, such as I have described in a previous chapter, is much more exciting than killing these sperm or cachalot, for which our tackle is unnecessarily powerful. But after all, in the pursuit of any kind of game, it is the hunting that counts as sport. The killing with any modern weapon of precision is nothing, it is the getting there that counts, and we have had many months both planning and hunting before we got this, our first bull sperm; also it is of greater value than the largest finner; and that must be our first consideration.

We found no ambergris ${ }^{1}$ in this one. It disgorged several cuttle-fish but they were not lost, for the sharks soon came round, and nothing comes amiss to them.

\footnotetext{
${ }^{1}$ Ambergris. See Appendix.
} 


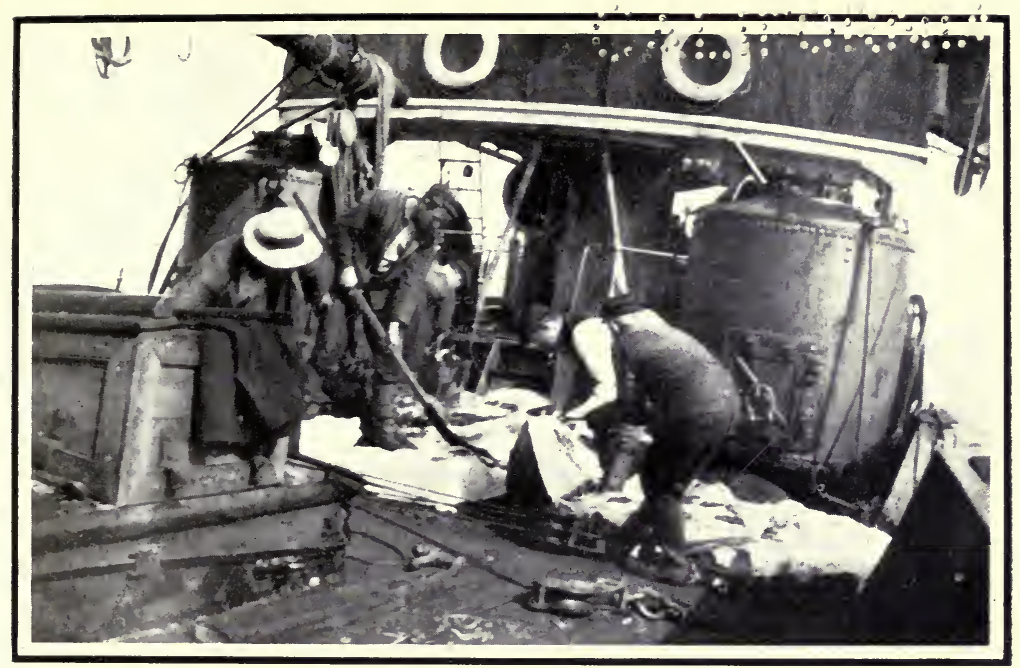

Cutting up Sperm Blubber

In the waist of the "St. Ebba." The boilers are in the background.

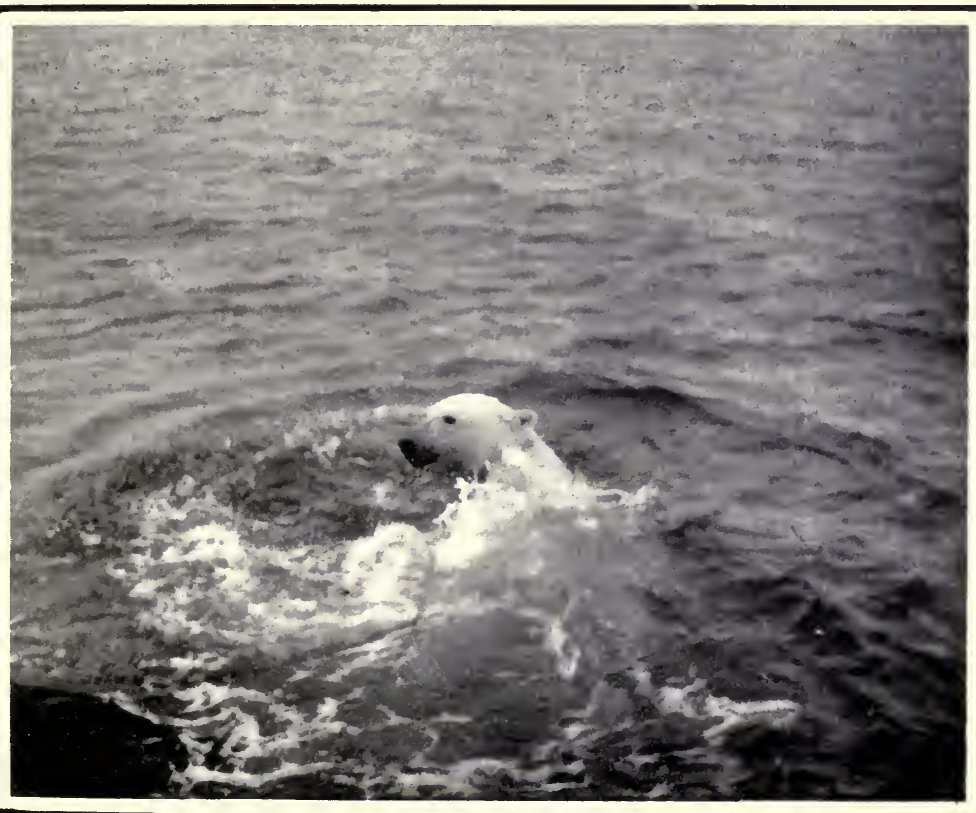

“Starboard" Trying to Get Out of the Lasso 

Ambergris is found sometimes in sperm's intestine, sometimes thrown from the whale into sea. It is used as the basis of scents. At present its selling price is 100 shillings per ounce. A whaler a year ago secured some from one whale, sold it for $£ 20,000$.

All afternoon we worked, cutting up the whale-first of all we made a cut round its shoulder and fin, or hand-a whale has bones like those of a hand inside the fibrous fin. In fact, the whale's anatomy is similar to that of a land animal, not like that of fish. The hip bone and thigh are only floating rudimentary bones.

We cut a round hole through the blubber, round the fin or arm, shoved a strop or loop of rope through from the under side of the blubber and pulled that taut on to a sort of button of oak called a toggle on the outside surface of skin. Then, with the winch's hook and chain hooked on to the strop, we pulled away, by steam power gradually raising a strip of blubber about two feet in width and of about eight inches in depth off the whale, as the body slowly revolved in the water, cutting it clear of the flesh with the flensing blades from the dory or flat-bottomed boat.

From the illustration you may form an idea of how the blubber is " made off." The head and tail parts were treated separately. Finner whales on a landing-stage on shore are stripped or flensed from end to end with an instrument like a sabre on a long shaft, but if we have to strip or flense one at sea, we shall have to do so in the same way as this sperm whale.

We worked late and turned in, all very tircd. The sharks that came round us to feed on our whale were a new experience to most of our northern sailors; they grew quite excited about them; some of them, instead of sleeping, stayed on deck to kill sharks. To kill one single-handed seemed to be the great ambition.

The first mate at breakfast to-day related how he harpooned his shark, fifteen feet long, in the morning watch, dropped a running bowline round its tail, and with a tackle got it on board by himself, and Henriksen, his elder brother, quietly described a cross with his knife's point on our galley roof! 
But it was quite true; and other men did so-a seamanlike piece of work. The harpooning is easy as shelling peas, but to make fast the line to a belaying pin and get a running bowline round the tail, and then hitch on a tackle and purchase to that and heave the shark outward single-handed needs sailorlike neatness and quickness rather than great strength.

We let the youngsters have their fill of shark-killing; when each has killed or helped to kill one, the novelty will wear off, and they will get accustomed to their company, and will not stop work to pay them more than a passing attention with the flensing blades.

At early dawn we recommence at the whale; our crew have not yet quite mastered the process, but they will do it. We have strong winches if few men, fifteen is our complement, about sixty used to tackle the job in the old style.

With practice and our captain's ingenuity and determination we will get Case, Junk, and all on board before midday meal. It is a thorough bit of sailor's work, every dodge of purchase block and pulley needed.

We have the junk now on board; it was a big hoist, and at the next port of call we will get some extra thick wire backstays to strengthen our masts, and so heave the next head on board with greater ease.

It is a marvel this case or long forehead of spongelike spermaceti oil, only covered with thin soft blubber skin.

The mass of fibrous tissue is even fuller of liquid oil than a bath sponge could be full of water. Whilst it was still warm we pumped it out with flexible steel pipes, but it condensed and choked the pipe. But when it grew colder we could just handle it. I should think it produced about two tons of liquid oil.

Now we have the long under jaw of white leather-like quality, with its double row of ivory-white teeth, on board.

This is where our plan of campaign differs from the most recent whalers; they either tow their prey ashore or into harbour alongside great floating ship factories of several thousand tons, to be cut up and boiled down. We cut it up 


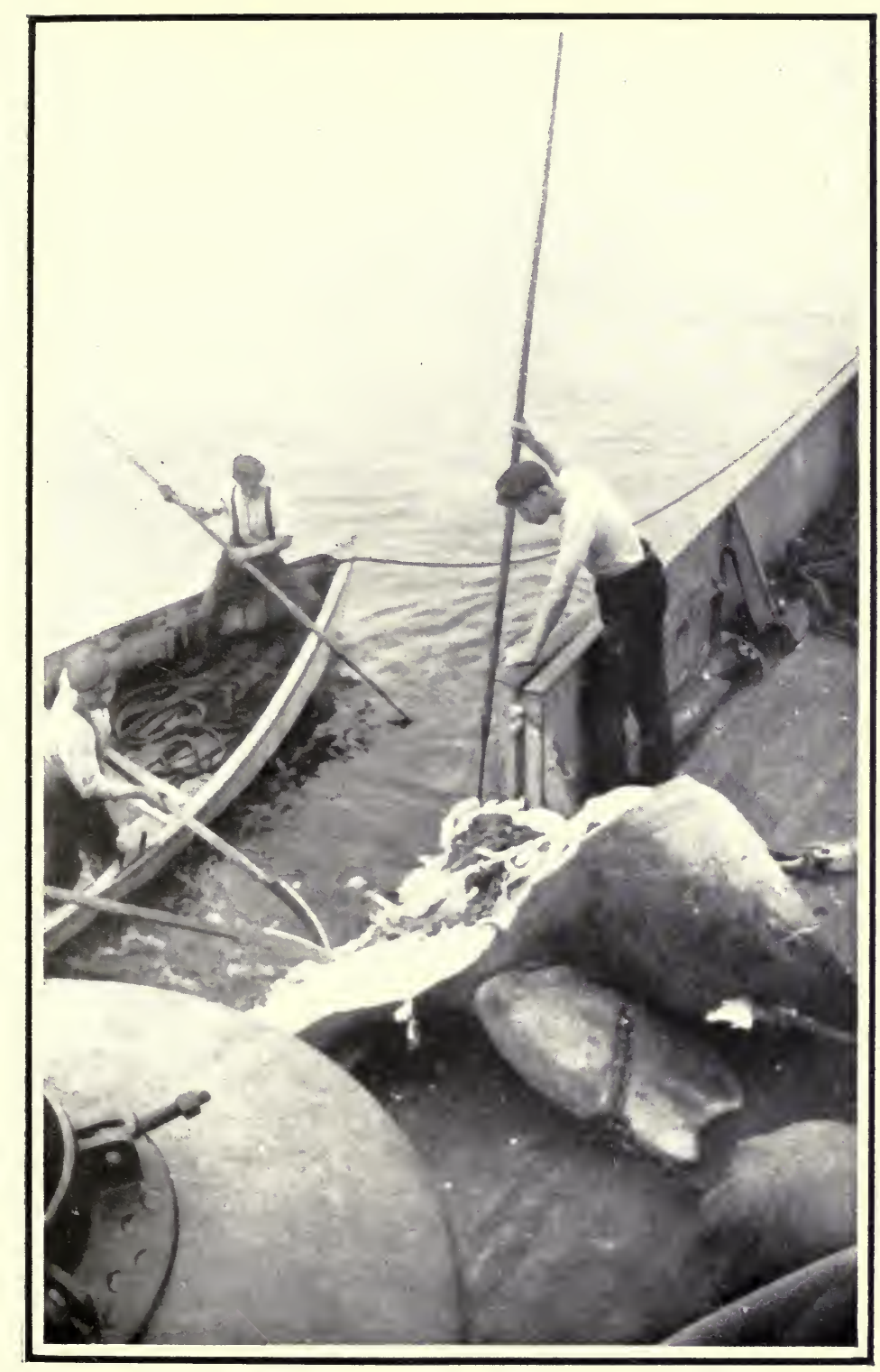

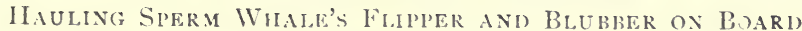
THE "ST. EBBA" 

at sea and take the blubber on board, melt or cook it, and sail away.

Our deck is now like a marble quarry, with great white chunks of fat in the moonlight, and dusky figures cutting these into blocks of about a foot square to go into our two pots.

To-day steam was let into them at one hundred and sixty pounds' pressure, and the cooker has to watch two taps running from these, each now pouring out beautifully fine sperm oil.

Our whale cooker is little more than a boy, but he is a bit of a chef already, having studied whale-boiling in these very remote frost-bound islands, the South Shetlands previously referred to.

He stands by the two pots on either side of our small ship amidships, one to port, one to starboard; now and then he dips a bright tin ladle into the oil that keeps running out into an open tank, and sniffs at it, and pours it back lovingly, examining its colour, which is like pale sherry.

There is no smell actually about our cooking process, till the water that is formed in the pots by the condensing steam has to be blown out of the bottoms of the pots. Then the blue sea gets a yellow scum and the atmosphere is pervaded far and near with the smell of beef-tea-the smell alone would make an invalid get up and walk for miles to windward.

At night it comes into my port under the blanket and permeates my being; we wish all whales at the bottom of the sea, but toute passe and in a minute or two the air is fresh again, and there is nothing left but a greasy feeling.

Each pot holds about fifteen barrels. I think this whale's blubber will fill them several times and produce, say, seventy barrels, at five barrels to the ton, and the ton at $£ 30$. This whale ought to be worth moneys, so we see a fortune increasing by leaps and bounds, and we put aside all thoughts of more delays and difficulties and losses.

It is sweltering hot on our lee side, the side on which we are flensing the whale. Our men take to drink!-a pale pink tipple brewed in a large margarine tin and ladled round; I think it must be one part red-currant wine to five of water; 


\section{WHALING AND BEAR-HUNTING}

I have tried it once or twice and always just miss the taste.

Blue sharks have pretty colours, especially when they are freshly caught, steel-grey and violet on their back, changing to green and white underneath. The long emerald-green eye in the grey skin is most effective-wicked-looking to a degree! Who has described the exquisite colour of the shark's pilot fish, with its upright stripes blue and white, like the wings of a jay, and who can tell why they swim in front of his nose-is it to give the shark a squint? And why do they sometimes change (there are generally two of them) and take up positions on either side of his dorsal fin, and move as the shark moves exactly, never getting an inch from the position, and then, without rhyme or reason, they will both swim away somewhere, and come back again?

I think the grimmest aspect of sharks is in a quiet moonlight night, when above the calm water you see their dark fins quietly circling round you, and sometimes there is a whitish gleam as one quietly puts its head up above the moonlit water and quietly takes hold of a lump of whale fat, and breaks the stillness by shaking it like a tiger!

Still another half-night at our whale-the deck full of moonlight and dark shadows, great cubes of sperm white as marble, gleaming knife blades, the light glinting on oily hands, arms and faces, greasy thumps as chunks of blubber are heaved across the deck towards the cooking pots. Two dusky figures stand on top of these, silhouetted against the blue sky and stars. We work by moonlight, for dark nights we shall have an acetylene flare. The spermaceti of the head we handle in buckets and bailers. It seems a question whether to bail the clean, slippery oil with buckets or grasp it with both hands. All hands work very hard, for every handful, every chunk represents profit to them, and they joke all the time, with never a swear word, as far as I can hear. The captain smokes and looks on and smiles at some of their remarks. He keeps his eye on everything without interfering unnecessarily. The mate, his young brother, and his men want to show what they can do, though this line of business is new to most of them. 
The cooking pots worked all night, and in my watch below, half awake, I dreamed of a hundred kitchens cooking beeftea, then turned over with a sense of great satisfaction at having seen our show well started the motor is going all right and we have proved we can approach whales as well as with a steam-whaler-a great satisfaction-and have proved we can flense a sperm at sea with such tackle as we have: and both the approach and the flensing before we left home were said to be impossible.

It is true that our flensing took a long time. But in the case of Right whales, Australis, if we are lucky enough to fall in with them, it will pay at least to take their whalebone at sea if nothing else.

On the old sailing-ship whaler, with large decks and powerful masts to use tackles from, and a crew of fifty men, more rapid flensing could be made than we can manage with only fifteen all told, including engineers, and a very small ship.

Our plan now is to try round about the Azores, if the weather is good, for another whale or two, then to proceed to Madeira, about two days' sail-I have seen several kinds of whales off its north coast-and then hunt south and west of Africa, down to the Cape, and then to the Crozet Islands for seals, or to the Seychelles, north of Madagascar, for sperm and blue whales, and possibly thereafter to New Zealand. Some islands we have information about south of New Zealand for Bone whales or Australis.

St Ebba got a few more whales in the latitudes of the Azores and Madeira, but the weather got too rough, so she continued southwards.

Possibly the end of the last chapter was rather oily and whaley, and smelt perhaps a little of filthy lucre. Perhaps I may be allowed, therefore, a chapter on flowers and Madeira - a day or two on shore and some tunny-fishing for a change from whale-hunting; though I must say that no two whale-hunts are quite alike; each has its particular thrilling interest, more especially the big finner hunting, for they are ten times more powerful than sperm. But repeated description, without depicting boats flying in the air and whales standing on their heads, and so on, must become tiresome 
reading, so as I cannot, from a casual habit of accuracy, invent thrilling incidents, let us to tunny. Tunny are not half bad fun when you have one on, but the waiting out on the blue rollers in a blaze of sun twenty miles from shore is trying, but when one comes on and your coils of line are whizzing out into the blue at a fearful rate, there is quite a lively time, almost anxious-for you have to be careful not to get caught by hands or feet in the coils of the line, which is pretty thick, just the thickness of this rather thick fountain pen with which we continue these notes. 


\section{CHAPTER XXI}

7 HE St Ebba killed a few more whales in the seas between the Azores and Madeira, but they were of

1 no great value-seihvale and small sperm-and the weather became tempestuous, so she proceeded southwards. The island of Madeira is thirty-five miles long and six thousand feet high. It was very hot on the south side amongst the sugar-cane crops and vineyards. But on the north side, with wind off the sea, high up in the mountains and riding through oak woods, bracken and heath and roaring burns, it was delightful, and probably more healthy than the slack air and life you have down at Funchal.

Funchal, the capital, is much the same as Ponta Delgada in the Azores, a white town with red-tiled houses and green blinds round a blue bay. But it is merely an open roadstead and has not nearly such a picturesque inner harbour as Ponta Delgada. It is a very quiet town; the only sound is the twittering canaries, and the occasional Hush of the Atlantic surge on the boulders.

There is quite a large contingent of British residents who have gone in for gardening strongly at their quintas. So that Funchal, in almost every month of the year, presents some astonishing flowery spectacular effect.

Geraniums are the least sensational. They pour over the walls of the lanes everywhere. I noticed one evening a high white wall in shade lit up with pink from the reflected scarlet of geraniums that hung over the opposite wall.

The jackaranda is the most amusingly pretty flowering tree. One morning you notice its bare indiarubber-like leafless branches, a few days after the bare branches are covered all over with bunches of Neapolitan violets-at least, they look exactly like them, and a day or two later the street is carpeted with the fallen blossoms and the golden I65 
brown oxen of the carros ${ }^{1}$ go wading through them, leaving dark tracks where the little polished pebbles of the cobbled road show through the violet.

I tried tunny-fishing off Madeira on several occasions. Perhaps this is a subject more suitable to introduce in a whaler's log than descriptions of flowers and canaries.

On one occasion I persuaded a hotel visitor to accompany me, with a crew of Portuguese.

The tunny, or tuna, is a mackerel; there are several kinds. Those I saw ran from about twenty pounds to three hundred pounds.

You have to start before daybreak for the fishing from Madeira, which is apt to put off intending tunny-fishers, but "41," as I shall call my friend at Reid's Hotel, after the number of his room, agreed to risk the briny and an early rise-I doubt if he will do it again-blue Atlantic rollers and a sub-tropical sun are somewhat trying.

Here are notes from my sketch-book of our day's proceedings, begun, I may inform the sympathetic reader, in the Palace Hotel before daylight.

... All is still-it is only three hours past midnight, the people in this caravanserai are all asleep-we alone are awake in the great empty dining-room-the night waiter and the writer-the writer cross and thirsting for an early cup of tea-the night porter does not understand this, but - he comes from Las Palmas, that is all I can learn from him. He is limp of figure and has black eyes and hair and his sallow face only expresses dull resignation and an unfulfilled desire for sleep in a corner : he is young, but I think no smile has ever passed over his chilly countenance in this life. $\mathrm{He}$ does not even move a feature or express the least remorse when I tell him it was No. 41, not 49, he should have awakened -fancy " 49's" feelings! so, to make sure, we go together and pull out No. 41-“41," in pyjamas, and red-eyed, seems to have forgotten altogether that he was to go fishing with me. Fishing at ten P.M., with a pipe and a grog, and fishing at

1 These carros are the cabs of Funchal, like four-poster beds, brilliantly painted, with chintz hangings, and sledge runners instead of wheels. Their progress is like that of a crab-neither fast nor certain. 
three in the morning are so different! So the writer and the mirthless waiter sit down again in the vast empty diningroom and wait whilst " 41 " gets into his clothes. . . . Now we are ready - an hour later than the end of above paragraph, but still tea-less. My fishermen and interpreter have been waiting under the palms in front of the hotel, smoking cigarettes and talking quietly and with interest, even at this dark hour of morning. We give them our thermos flasks, with only cold coffee in them, and our provisions for two days, in baskets, and with them we steal into the night round the hotel gardens and terraces, trimmed with tenantless wicker-work chairs, under the palms, pale

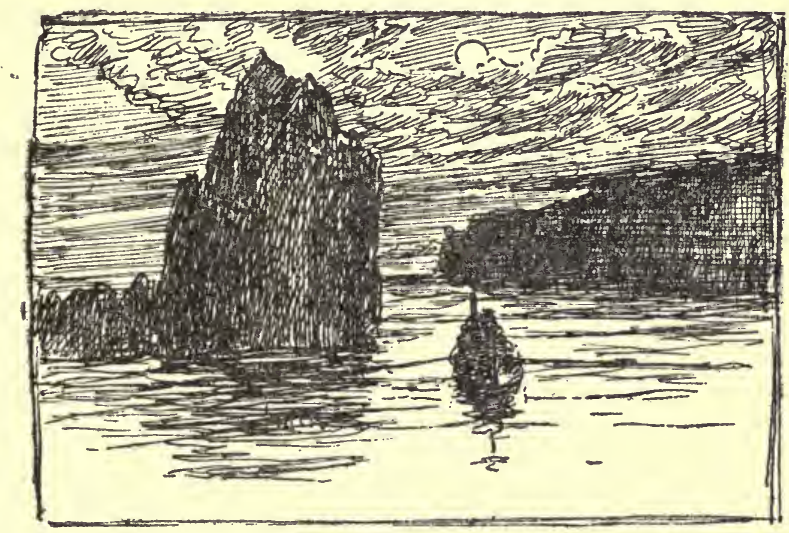

in the faint moonlight, down the steps, over the cliffs with care, through an iron gate, we must look like conspirators, but we only feel sleepless; down and down, till we come to the bathing steps and dimly discern our boat and men rising and falling in the grey foam. We embark with difficulty, with our provisions, and row off. The moon in the west breaks a little through the clouds and cheers us with its broken reflections on the long swell. " 41 " is in the stern, the writer in the bow, four rowers and the interpreter between us.

We pass under the cliffs to the west of Funchal Bay, rowing steadily with two long sweeps, two men to a sweep, close to the surf on the rocks, and pass a blow-hole in the 
rocks, where the rising surge makes a fountain of fine spray through a hole in the rocks, very like a whale's blast. It is blowing intermittently, dimly seen in the moonlight. As we pass the outstanding rocky island opposite it we catch a faint land breeze and step our mast and set the mainsail and slip along in absolute silence.

It is a long sail, we have nearly twenty miles before we get to the place the tunny frequent.

We pass the fishing village of Camara da Lobos (place of the seals), several miles to starboard. It nestles round the head of a bay - the deep glen behind it in shadow, the white houses in moonlight-a few yellow lights move about, our crew live there.

Under the cliff of Cabo Girao we closed our eyes for, it seemed, a minute, and opened them to find a change. The sadness of night was gone and it was all hilarious blue day.

How quickly the night goes, even in the sub-tropics; as fast as it falls, almost in a minute, the moon's sheen on the swell is gone, and the glorious sun shines again, from behind us over the east end of Madeira. Due west there is a lapis lazuli blue sky over a bank of pink cumuli, the full, golden moon seems to stay one moment in the blue before it sets behind the bank of cloud; then all the sea and sky is the blue of the tropics again, as it was yesterday and the day before-great swells of a rippling blue sea, and a blue sky, and that is all, excepting our little selves and our green, red and yellow boat in the immensity.

The features of our crew are now clear to us, and they unwind the cloths they wore round their heads for protection against the moonlight and night air. Alas, "41" still tries to sleep, and so does the interpreter; I fear the motion is the cause-the rise and send of a small boat in the Atlantic is very trying. Ahead of us there is one sail like our own; we see it now and then as it rises on a blue swell; now the top of the white sail catches the golden light of the sunrise, then far away beyond it something, a mere speck, appears for an instant, then another, there are boats out there fishing; it comes quite as a surprise to find fellow-creatures out so far from shore in small craft. We cannot count them, 


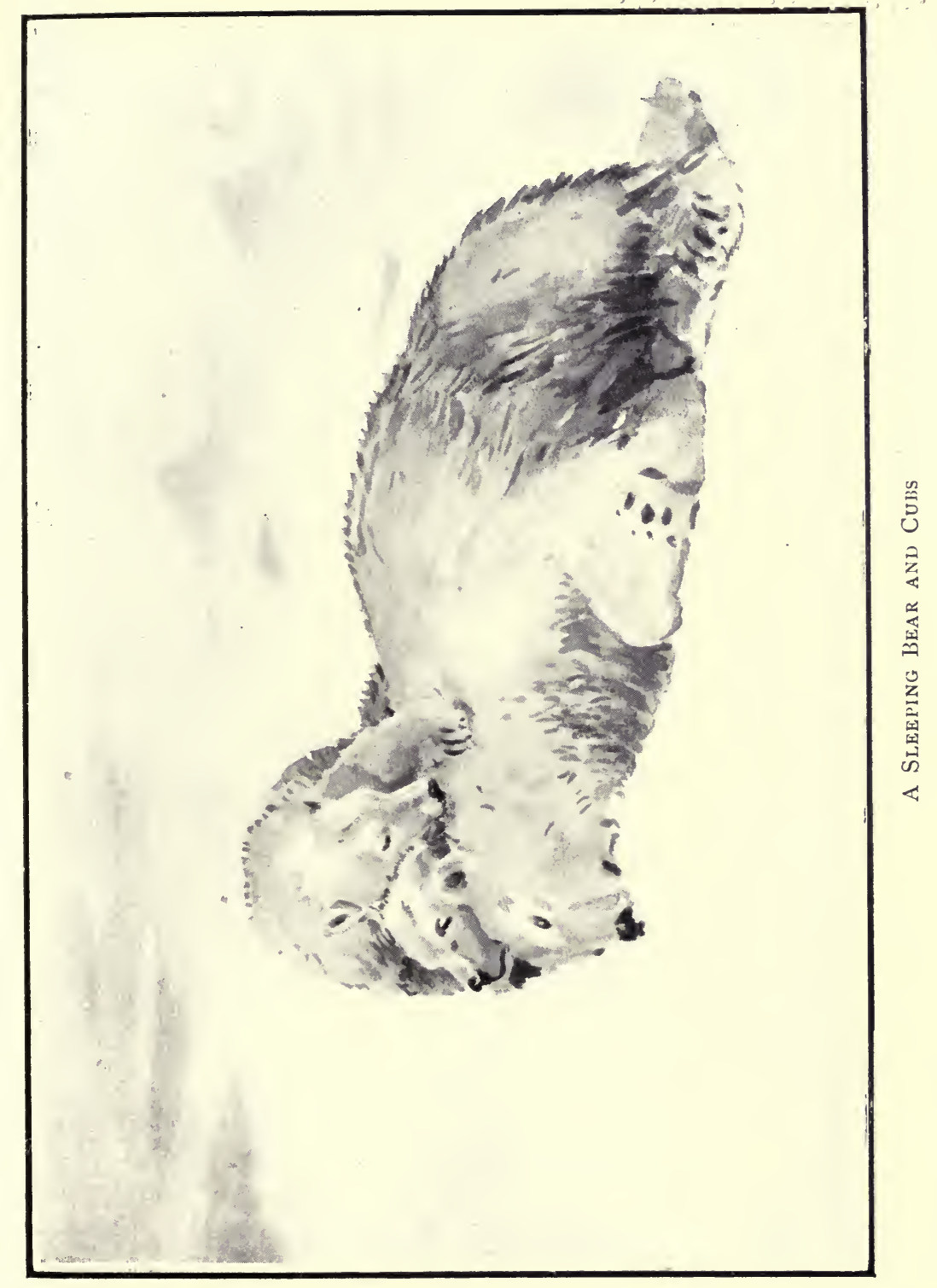




$$
\therefore \cdots
$$


for we only see three or four at a time, as they appear in turn on the top of the swell. Now the sail in front drops, and the boat is like the others, with the mast down, and oars out, and little figures standing out silhouetted against the sky for a second, then lost to sight. In another ten minutes we have joined the fleet, and dip our sail and stow our mast away.

And the colour of these mariners! We can hardly begin to fish, so great is our desire to gloat on the appearance of each boat-its weathered brilliant colours and its crew as it appears in its turn over the back of a blue glittering swell. Camara da Lobos men all wear wide straw hats, with a broad black ribbon round them, so their brown faces are in shadow; their shirts, originally white, are tinted like old ivory by many washings and voyages, so were their cotton trousers, and tattered and patched most wonderfully. The boats are striped yellow and blue, with perhaps magenta, and blue oars ; coarse enough colours they would look under a northern sun, but here, with the complementary tints from the strong light, and all repeated by reflections in the blue sea, they become a sight to rejoice anyone with half an eye. The fishing, however, soon engrossed our attention.

As a preliminary to tunny-fishing you have to catch large mackerel as bait and smaller mackerel to throw out into the sea when the tunny comes along in order to keep them in your neighbourhood. For the small fry we fished with a yard of cane and a yard of line and a small hook baited with little cubes of mackerel. The captain chopped up some of these into a fine paste on a board with a machete and put the paste into the water to draw more fish; as it faded away down into the clear green depths, swarms of these little fish, about four to the pound, dashed to and fro, eating it, and every now and then one would take our bait, when there was a flash of silver in the water, and out he came to join his neighbours in a bucket.

Another of our crew, "Bow," we will call him, rigged a longer hand-line and fished deep, and soon pulled up some magnificent spotted mackerel. This bait-catching was apparently the object of the early morning start-large 
mackerel for bait for the tunny, and small fish to catch the mackerel. The small fish, when they are let loose, are supposed to hug the shadow of the boat and so keep the tunny in the neighbourhood: besides this purpose, they form our principal food at midday.

These large mackerel were kept alive alongside on tethers, hooked by the nose-with a rather clever rustic swivel on the line-kept alive to be used for the tunny. But usually a big basket is kept floating alongside, into which are put the live bait, large and small. There was so much going on ; so many little fishing dodges new to me that I must have missed much; what held my attention were the great coils of strong hand-line, thirty fathoms in each, thick as the average man's little finger, with brass-twisted wire trace, fifteen plies, each with thick iron hook at its end.

After we had caught enough mackerel we went several miles farther out to sea, and the two men in the stern each made fast a large mackerel to his line-put the big iron hook through its nose and a fine wire twisted lightly, from the shank to the neck of the barb to prevent the fish working off.

Finally we had four of these live baits and strong lines at different depths, drifting astern; and two men at the oar gently paddled to keep the boat in position and the lines up and down. For hours we sat so, and thought tunnyfishing uncommonly dull.

If one could speak Portuguese it would help to pass the time. What fun it would have been to get the local "clash" from these pleasant-looking men, all in tatters, miraculously stitched together. How curious would have been their views of life and their experiences and traditions, but my interpreter was sick as could be, and made neither moan nor attempt at translation, so the crew chatted and better chatted between themselves, and laughed occasionally, and so passed the time, whilst the writer patiently and silently held a line for hours, waiting for the huge tug that seemed never going to come.

But the next boat to us soon got one-a whacking big fellow; he fought them for an hour and a half and they gave 
him twenty strokes of a bludgeon on the head in a smother of foam alongside the boat, and pulled him over the side with two huge gaffs and ropes, and then sat down exhausted. $\mathrm{He}$ was about two-thirds of the length of the boat and must have weighed well over three hundred pounds, and was worth $£ 3$ at the market, to the two men and two boys who got it. Lucky fellows! They lifted the boat seats to show it to us, and there it lay, a silver and blue torpedoshaped fish with huge deep shoulders. The natives call the tunny albicore. We congratulated them and gazed at it, and listened to their gasping description of the fight, how it had sounded seven times and taken out a desperate number of lines. Then other two boats lost one each-that

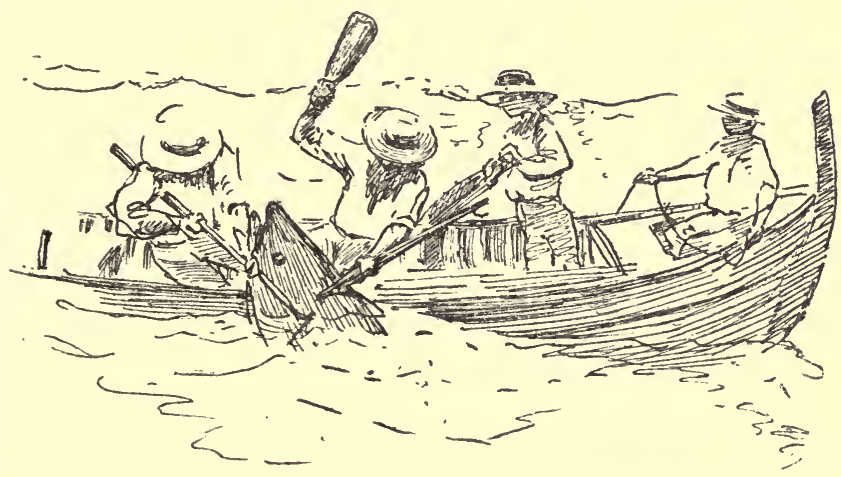

is, they got into fish that were too big for them, and made their lines fast, and the fish broke away. Time was their consideration; they prefer several smaller fish of, say, one or two hundred pounds to a bigger one that may weigh five hundred pounds but will take the whole day to play it.

It got tiresome as the hours went by with never a soul to speak to, for " $4 \mathbf{1}$ " and the interpreter were both still ill, and the sun got very hot, so we decided that after midday meal we would up stick and make sail. A flat hearth of charred wood was laid amidships. Three small boulders were laid on it and sticks between, and these were lit and a great tin can of sea-water was set on the stones to boil, with the fish, and sweet potatoes, in it, and a right hearty meal we made, with fingers for knives, and the blue Atlantic for 
a finger-bowl, and the appetising meal was washed down with water from a barrel and some ruby red vino pasto wine fit for the gods. . . . Ah, well, better luck next time, we were saying, as we were about to haul in our line, when the tug came, a most tremendous tug!

We are fast in a tunny at last! and a pulley-haul fight begins-what a weight it is! You feel as if you were pulling up the bottom of the ocean for a second, and then that it is pulling you, willy-nilly, into its depths, therefore you let go line, and jam it down on the gunwale to check it, and it runs, squeaking, out, cutting a groove in the wood. I cannot tell you how much stout line went out-there were many lines the thickness of flag halyards of thirty fathoms each, attached to each other-but the whole stern of the boat seemed filled with wet coiled-down line when we had been pulling in for a few minutes, and then, in a minute, it was almost gone, and then wearisomely two of us pulled it in again, hand over hand, with much gasping and tugging, more and more line is coiled up in our stern sheet, but still no sign of the fish. As the fight-pull devil, pull baker-proceeded another man managed to pull in the other lines all in a heap, and we were able to devote our united attention to the fish. It seemed strong as a horse and took us practically all in charge, and we had to be nimble to let the whizzing loops of hard line get away clear of our feet and wrists. We were pretty well blown, cut and sore, by the time its efforts lessened. Then we got in coil after coil, six coils in hand then lost two, then eight and lost one, then set teeth and pulled steadily with both hands between times, and at last and at length, the silver glitter we expected showed deep down in the blue. Even then there were many more coils to bring in; the water being so intensely clear, the enormous mackerel showed many fathoms down, swinging round and round. . . The latter part of the fray needed instantaneous photography to depict it-what with the tunny pulling and our weight all leaning to one side to get the line in, and then to gaff the fish, and the roll of the sea combined, too many things happened at one time to be very clearly remembered afterwards. We had two gaffs-huge affairs-and as the tunny dashed here 
and there we managed to get one into it, then the second, and we lurched half-seas over; the tunny was kicking up a smother of foam all the colours of the rainbow! Then with the gaffs we pulled its head out of the water up to the gunwale, and banged it twenty times with a wooden thing like an Indian club till it was still, or only quivered, then a lurch from a blue sea seemed to help to get half of it on board, and a big heave and it all came in, and we lifted a seat and put it along the bottom and raised ourselves and waved our hats. It was quite as good fun as any salmonfishing I have ever had, and nearly as exciting as whaling; that is, during the actual playing, but the previous waiting was trying beyond words, you get roasted by the sun and bitten by salt spray and stiff and cramped-you "chuck and chance it," and chuck but once in half-a-day and may have to wait days and days before you catch your first tunny.

Getting all the lines clear again took a long time and neat and patient handling; we did not help at that, we were rather tired. But we watched the iridescent colours of the tunny fade; in half-an-hour its brightest blues and shimmering pinks and silver were almost gone, and changed to dark green on the back and dull silver below. Fifty-four kilos we made it out to be-five feet three inches long, with enormous girth. Unfortunately I lost its chest measurement, but think it was four feet three inches. The three-hundred-pound tunny we saw caught close to us was worth $£ 3$ at the present market value.

At four we gave up. The everlasting rolling in hot sun on tossing sea, however beautifully blue, as you lie drifting, becomes very trying in a small boat; besides, the native fishermen themselves all knock off between three and four. But we must try again, and some day, when we thoroughly know the ropes, we will get a small sailing craft and try the business single-handed, for there is a lot of fun, in my opinion, to be had fishing so, for trout or salmon-to play your own salmon and gaff it, or manage your boat and trout and land it, say a five-pounder on fine tackle, is excellent, but to land 
a tunny single-handed, doing your own sailing and gaffing, would be-just sublime!

It was pleasant sailing back to land close-hauled with the fresh breeze, which had risen with the sun and turned the smooth swell into crisp waves with blue breaking tops, that soft and white breaking sea of the Trades that is more caressing than threatening. Most of the other boats gave up fishing at the same time, about three P.M. The skipper gave me the tiller ; neither of us could speak the other's tongue, but there is a quick understanding between all of us who sail small boats, and both skipper and boat seemed to become old friends to me. They are better sailing craft than I had fancied, though they do not draw much, for they have to be beached; but they have two bilge keels, which make them sail pretty close-they all sail closer and are "lighter in the mouth" than I had expected. You notice in the drawing they have a high stem and stern post, and the rudder ships just as it does in the boats of the north of Norway. The sail is simple, a large square dipping lug- the canvas from Dundee - the tack is made fast at the stem, or a little to either side, and the sheet is simply rove through a hole in the gunwale of the sharp stern.

We got ashore at last and " 41 " and the Juan Fernado, the interpreter, revived and spoke again as we got into smoother water.

We climbed up the cliffs in the late afternoon and " $\mathbf{4 1}$ " had to explain to José, the major-domo of the hotel, why we did not stay out all night, as we at first intended to do-- "No room in boat," etc., etc., he said, and José smiled his genial smile and said: "Told you so, told you so, eet ees dee same ding always, gentlemen do come back so; dey not like de smell of de feesh, dey say."

Now there is the moon again, I declare! I began this chapter by its silvery light before dawn, and now it appears again as I wind up my notes at night; it surely has done its round at an unusual pace; it seems to me only a minute or two since it went down in the west, ruddy as a new pennyit had only a small gallery then-mostly fisher folk; this evening the hotel people are all watching it from a verandah ; 
they will be late for dinner, so beautiful is its yellow glory and its track across the sea from the Disertas to the foot of our cliffs. I must make a study of it to-morrow and will need a ruler to draw the black shadows of our masts, so straight are they along the path of gold.

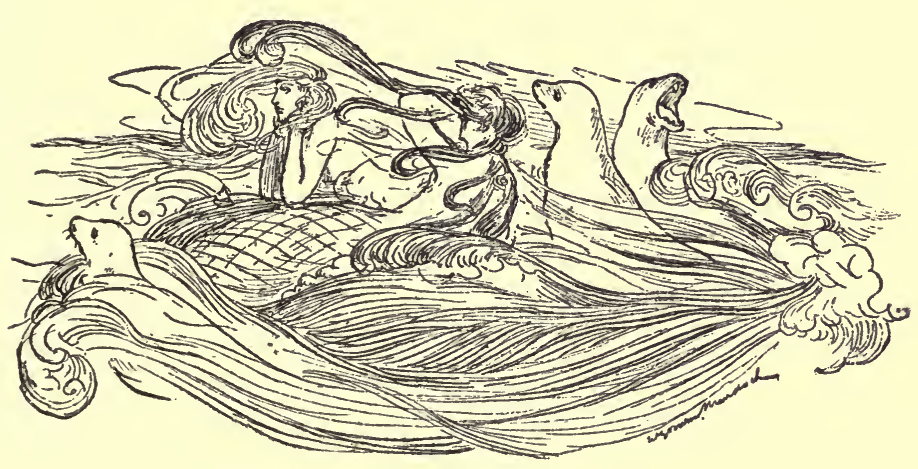




\section{CHAPTER XXII}

FTER killing our first bull sperm off the Azores
we killed a few more whales, north of the Line,
rorquals and small sperms of no great value. Then, owing to the warm water of the tropics not cooling our engine sufficiently, we had more engine trouble on the voyage from the Line to Cape Town. One day under sail and engine, the next drifting and tinkering at the engine. At the Cape, however, relief came; a Norwegian expert at Diesel motors was sent out and he diagnosed the trouble at once, increased the flow of cooling water, altered the screw slightly and got the St Ebba into splendid trim, and the old engineer, a Swede, went home.

Under sail and motor our little vessel did a record passage up the Mozambique Channel, in heavy weather, past Madagascar to the region of calm seas round the Seychelle Islands, five degrees south of the Line. We would rather have gone south instead of north, to the Crozet Islands, for the seaelephants which we know are there, but, owing to the last two vessels that called there having been wrecked, insurance rates became prohibitive; so we acted on the alternative plan we had formed in Norway, and went to the Seychelles to find if my old whaling chart said sooth about the sperm there. I had also heard from old whalers that there were many blue whales, and these we knew had never been hunted, and the sperm we counted on having increased in numbers; since the sperm-whaling was almost given up forty years ago. Our forecast was correct; we found both sperm and rorquals in great numbers.

We set to killing and flinching (or flensing) the sperm whales at sea. But we soon realised that for one we killed and flinched at sea we could take and utilise a dozen with a shore station; for the labour, French Creole, on the Seychelles is plentiful and cheap. Besides, we were losing not 
only much oil, owing to the warmth of the water, but also the use of the bodies of the whales. One of these drifted ashore beneath Government House. It was very high, and we were politely informed that-that was the limit!

So we applied to the Seychelle:Government for licences for a large land station in order to utilise both the blubber and the entire bodies of our whales. Licences were granted to us and we purchased the land site for a station; and now we are running our little Company into a large affair, with both British and Norwegian Directors and capital, and the station is being prepared-a complete land station, to work with several whaling steamers; capable of turning out, by the latest processes and modern machinery, several hundred

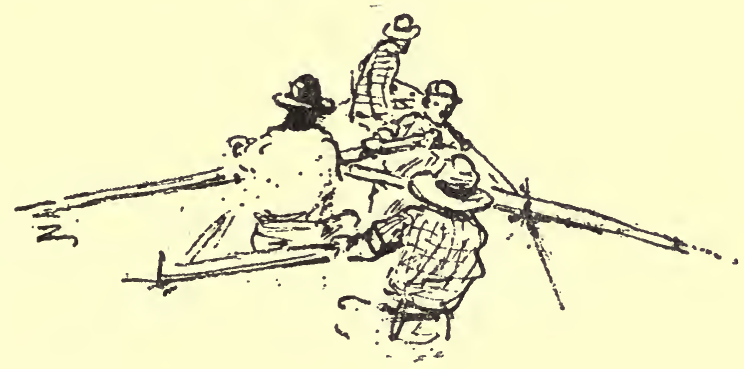

barrels of oil and bags of guano per day, the guano being produced from the whale's bones and meat after all oil has been extracted.

Now I have come to a point in this relation of the history of the St Ebba when I find myself in the position of a historical painter who was decorating a building in New York with a historical frieze of American history, and he stopped. "Why," said his patrons, "do you stop?" "Why," he replied, "because-you haven't got any more history!" So our St Ebba's history must also stop in the meantime. Possibly we may join her again and go on with our narration, and paint blue seas and coral strands fringed with waving palms, and hunt whales where there are never gales, and turn turtle and catch bonita and tunny and so on. Meantime we leave her at anchor in the Seychelles in charge of the mate, engineers and two men. The mate writes that his crew 


\section{WHALING AND BEAR-HUNTING}

strike at turtle soup more than three times a week, and Henriksen has gone to Norway about the outfit for the new station and steamers for our developed Company.

Here it was the writer's intention to bring in some notes about whaling in the Antarctic regions, 1892-1893, partly because they might contrast interestingly with the following recent notes on the Arctic seas, but this promised to make too large a volume, so we miss the Antarctic and go direct to notes about hunting and drawing in the Arctic.

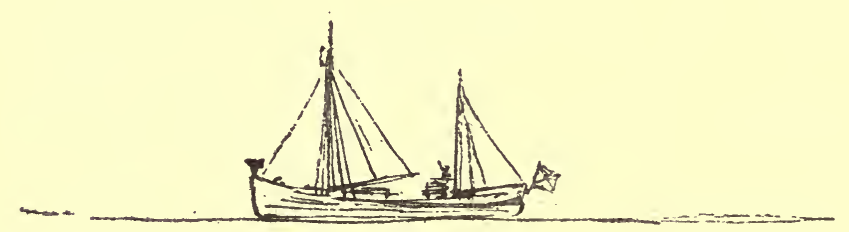




\section{CHAP'TER XXIII}

$\mathrm{N}$

OW we come to notes about the Arctic regions, whales and bears, promised in the preface to this

Long ago the writer, as a very small boy, vowed to go North and bring back bearskins. His instructress failed to excite his interest in short sentences, such as "The CAT ATE the Rat," so she gave him a little square green book by Ballantyne, called "Fast in the Ice," and he at once made rapid progress, and he promised his instructress that he would go to Greenland some day and bring her white bearskins-now he has got them; but it is too late!

With this brief introduction we come to the subject of a little North Polar expedition we arranged this year (1913), six of us, to hunt for whales, musk oxen, walrus, seals and bears, or anything else of value in the way of heads or furs, which we could find.

I need not go into the financial aspect of the concern, but I may say my principal object was to study the Arctic regions as compared with the Antarctic and to make pictures of the northern ice, and animal life.

Dr W. S. Bruce, my companion of long ago in the Antarctic, came to see us off at the Waverley Station, and gave me a volume by that very remarkable Englishman, the whaler Scoresby, a scientist and whaler of the Arctic. That and Dr Bruce's own splendid book of reference on the Antarctic and Arctic ("Polar Research"), and my friend Captain Trolle's work on the Danish expedition to East Greenland, formed our Arctic library. Trolle's description of the Danish expedition came in particularly well, as our intention was to visit the part of North-East Greenland, north and east of Shannon Island, which they charted in 1906-1908, and where, alas! they left their first leader, Captain Mylius Erichsen.

"We," I had better say here, will often stand in these notes 
for my friend C. A. Hamilton of Cochno, and Dunmore, Stirlingshire, and myself; we have done a little whaling together, and he gave me his good company a few years ago through the rough and smooth of hunting black bear and caribou in the barrens of Newfoundland. The rest of our party were four Spaniards, one of whom, F. J. de Gisbert, made the bundabust for this voyage, chartered our diminutive whaler, at Trömso, provisioned her and arranged about captain and a Norwegian crew. De Gisbert is to lead the proposed Spanish National Polar Expedition, and is at present building his vessel, which ought to be second to none, as a floating oceanographical laboratory and ice-ship. It is to be a four or five years' drift across the Polar basin east to west, somewhat after the manner of the Nansen expedition, benefiting from their work, and carrying out still further observations with a staff of Spanish naval scientists specially trained in the various branches of natural science in the high northern latitudes.

It is a long road to North-East Greenland by Trömso and the north of Norway, and so many people are familiar with the Norwegian coast that the reader may care to make one jump right north and join us on the Fonix, a few hours out from Trömso-to join our rather curious little party in the cabin of a very small whaler; so we will avoid wearisome detail in the latter part of this book about fitting out our vessel, such as those with which I have perhaps burdened the first part about our St Ebba.

So we raise the curtain in the cabin of the Fonix; De Gisbert and Archie Hamilton are at chess, whilst the writer and our young Spanish comarados, two brothers Herrero and their cousin, Don Herrero Velasquez, are playing cards, drawing, and speaking in French, English, and Spanish, separately or all at the same time.

To add to the vocabulary, Svendsen, our skipper, comes in with his collar up, from the cold outside, and taking Gisbert's guitar trolls out Norse sea-songs. Three of us " touch" the guitar, and we also have bagpipes and a mouthorgan. It promises to be quite a homely and musical party. The engine goes beautifully quietly-but we know from 
the wind and the low glass there must be a heavy sea outside the fiord, and we are heavily laden with coal on deck!

The evening passes with snatches of Spanish songs, and bits of sailors' chanteys, and we have one bottle of rum between us all as a libation for a successful voyage and a "full ship."

Then, alas, we strike the rough sea outside the fiord, and roll and pitch as only small whalers can. But still the three cousins trill away at songs, bravely, bravely, though they grow more pale. Then they retire one by one to their minute cabins ; turn their keys and shut themselves in their bunks and hide discomfort. How they live without any air is a wonder-and after two days they turn up again, smiling.

A word here about our little whaler, the Fonix, and her build. She is just a handy size for dodging in and out amongst the ice, and she is said to be strong. She was built in 1884 for bottle-nose whaling, and for use in the ice-ninetytwo tons register, two pole masts and a funnel, one hundred and forty horse-power, eight and a half knots in calm water, over all one hundred and ten feet, with broad beam, her sides are sheathed with greenheart and oak two feet thick; her ribs are eleven inches by twenty inches broad, with only five and a half inches to six inches between them at bows. The forefoot has a five-foot thickness of timber and the usual belts of iron round the stem or cut-water, to protect it when ramming ice.

Between 3rd and 6th July we are all seedy, there is no gainsaying it, the writer perhaps makes the best pretence not to be so, and is rather envied; and several of the crew are down, it is not nearly so bad though as last year on the St Ebba, where, out of a crew of fifteen seasoned hands, the skipper, first mate, and writer, were all that could stand a watch for three days after sailing. That was, however, in a pucca gale. Still, on the Fonix, we managed a game of chess or two between the appearance and disappearance of our señors, and worked a little at Spanish and strummed mandoline and guitar-Gisbert playing the mandoline, the writer accompanying him on the guitar, whilst all well enough joined in the words. 
I was never with such a musical party. The steward also plays the guitar, and, with a wire arrangement attached to its neck, holds a melodeon or mouth-organ to his mouth and makes a very clever but horrible orchestral effect.

To-day, the 7th of July, Monday, we are into calmer water, grey sky and cold-we passed a little ice at night and met our first ivory gull, it is the harbinger of the North Polar regions, as the white petrel down South tells of the ice edge. Last night we drew lots for watches, Hamilton and I take ours together-we take the second six hours watch-Don José and his brother Don Luis ${ }^{1}$ take the first six hours, and their cousin, Don Luis ${ }^{2}$ and De Gisbert take the third; this arrangement allows us a change of six hours each day. The idea is that the two on watch are to risk their lives against any whale, bear or ferocious animal that may turn up on their watch. To cheer us up on this somewhat quiet evening, Gisbert yarned to us about his previous trips to the Arctic; and told us about some of the ice-protected vessels that lay round us in Trömso. One of them, the smallest, a mere twenty-tonner, with a crow's nest at its short foremast, he told us, came back from the ice single-handed a year ago! Another, a yacht-like auxiliary schooner, with fiddle bows, but heavily protected, a year or two ago was up at the west ice - that is, east of Greenland-with a party of Germans. They became overdue and a search party in another small vessel set out, which called at Jan Mayen Island on the way north, but found no signs of the lost party; so they pursued their way north into the floes-hunted about till they burst their ship up, and only one man returned. On comparing dates the first party was found to have actually called on their return journey at Jan Mayen and left only twelve hours before the relief party called. A letter left at the hut on the island to this effect would have saved fifteen lives of the rescue party.

As we are going to the "West Ice," north-east of Greenland, such stories give a sense of anticipated troubles to our little trip-if, however, one only thought of the dangers of life, who would go motoring or eat a fish or go to bed ?

1 Don José and Don Luis Gongolez Herrero.

2 Don Luis Herrero Velasquez. 
De Gisbert has picked up several stranded sealers, on his previous expeditions north; a lot of these set out in poor vessels with no equipment; for fur-hunting, for blue fox, bear and seal skins; and they often came to grief. A party of four wintered in Spitzbergen, badly provisioned, and when he fell in with them, one lay dead, a second was in the last stage of scurvy, and the other two were barely able to come on board and tell their tale. De Gisbert took the sick man and isolated him-and a distinguished doctor on board said he had not a chance of life, half his face was gone. He asked for beer, and the doctor said: "Give him as much as he likes to drink. He is a dead man." So he got that light Norwegian ol, more and more of it ; he drank one hundred and fifty-six bottles in five days, and recovered!

Another troublesome sealer he took home had gone crazy on board a small boat on its outward voyage. De Gisbert hails all sealers and gives them tobacco and their longitude and latitude, and possibly a bottle of whisky, all of which things they are generally quite without-as often as not they carry neither sextant nor chronometer. He was asked to take this man who had gone crazy back to Norway, and as Gisbert was on his way south, to save them their season's sealing, he humanely did so. The man partially recovered and was let loose, and messed forward, in the fo'c'sle. But suddenly one day, at meal-time, he went mad again and cleared everyone out of the fo'c'sle with a knife in his hand; and they had to lasso him through the fo'c'sle skylight! Naturally they put into the first Norwegian village they came to up north and asked the police to take over the lunatic; but the police besought Gisbert to take him on to Hammerfest and they would telegraph and have him met there. He did so, much to his own loss of time, and at Hammerfest one small boy came off in a boat to take, single-handed, the raving lunatic, who required two strong men and a strait jacket: he died two days after.

De Gisbert talks of his plans for this coming Spanish Polar expedition and finds the writer a sympathetic listener, for have we not worried ourselves over similar troubles, the raising capital and planning of an expedition to the FarSouth? 


\section{WHALING AND BEAR-HUNTING}

We sight ice in the afternoon, and grey and cold it isalas, that the thrill of the first sight of ice should not repeat itself. My young friends do not seem to be greatly impressed, not so much so as we were years ago, when, after a three months' voyage, the mist rose and we had our first vision of the marvellous architecture of Antarctic ice.

Here it is not so impressive as in the South, but beyond doubt it can show its teeth quite effectively. Curiously it is often the old, experienced deep-sea sailor who feels the greatest sensation on going into the ice for the first time. All his life he has religiously avoided knocking up against anything in the way of ice or rocks, so when he is called to go straight in amongst ice-blocks it affects him more than it would a landsman. I know of such a captain and his first experience

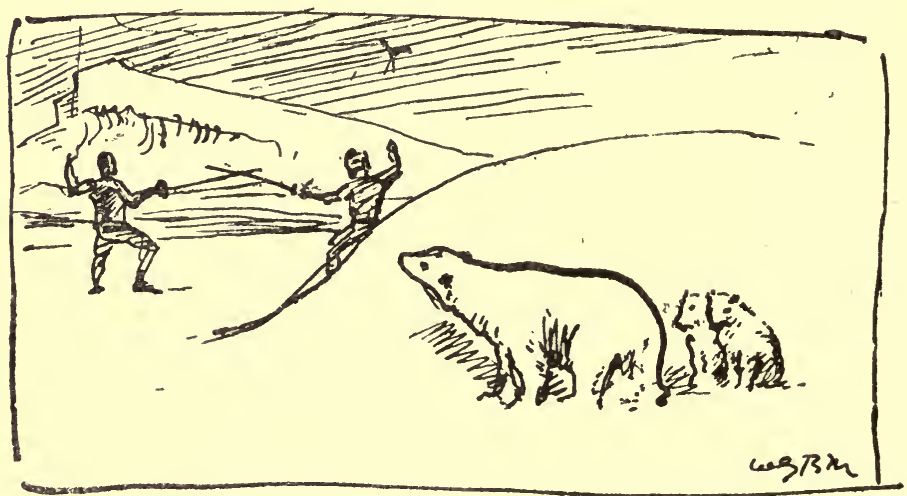

up here. When he had brought his ship into the ice, the crashing and thumping got on his nerves so that he retreated to his cabin, and bolted himself in, and had to be fed through the skylight for three days. This is a true bill.

We have got some sail set to a westerly breeze and go so steadily that we can vary our amusements of lasso-throwing, etc., etc., with fencing. The señors are interested in fencing but are not very good, but they are good shots at clay pigeons; that is another side-show we have, De Gisbert is quite a showman at it. With a five-shooter shot-gun he throws three clay pigeons up with the left hand and shoots them all before they reach the water. But at fencing the writer has rather 


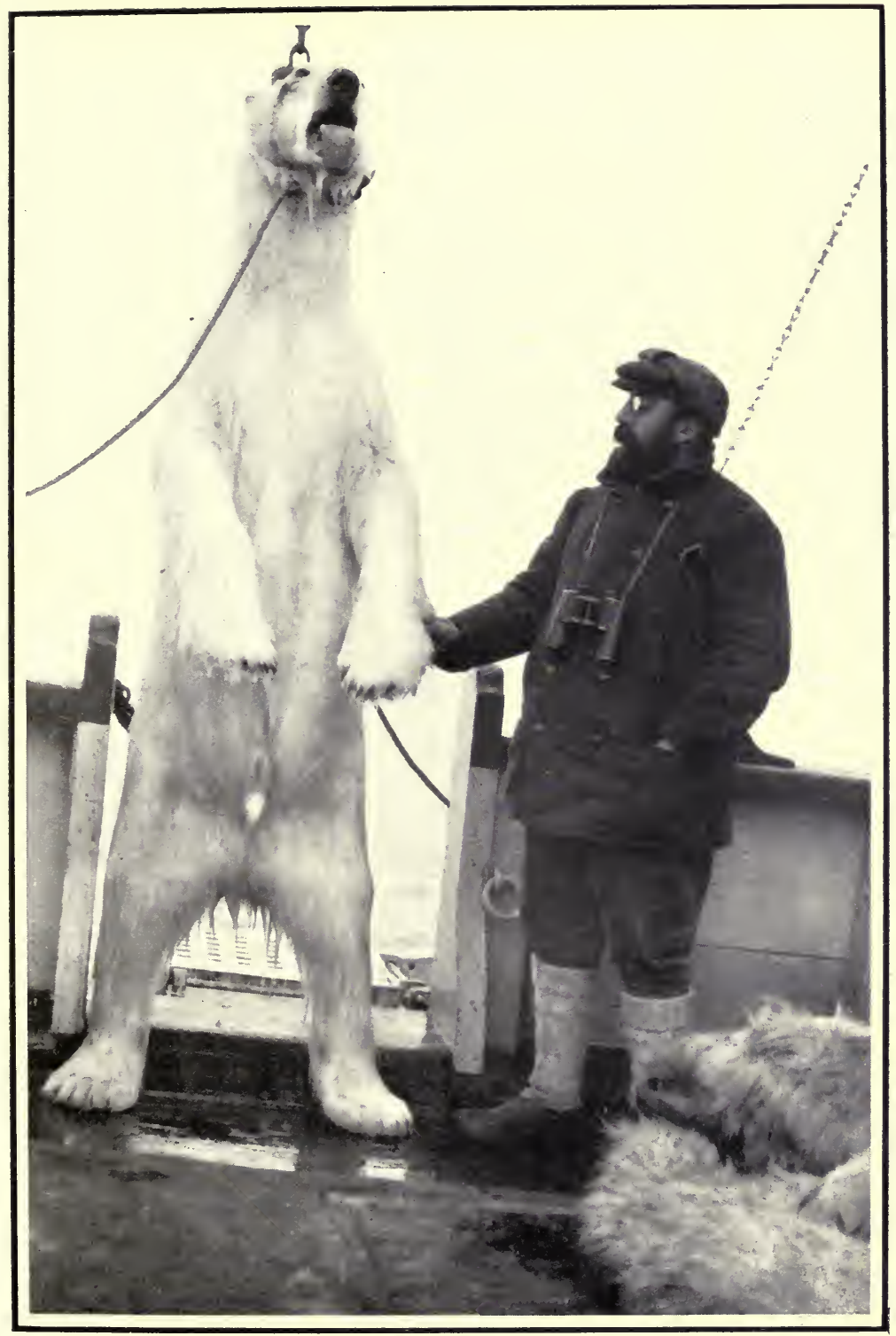

A Dead Bear Being Lifted on Board by Steam Winch and Chain 

a pull, the last three years' practice in Edinburgh with our most perfect teacher, M. Leon Crosnier, ought to have some effect.

In Gisbert's Spanish Polar expedition next year, or the year after, all men will fence for health's sake. But who will instruct? that is the art-fencing without an instructor is hopeless.

A seal or two appear to-day and some little auks.

We get the lines and harpoons ready for our two bow whale-guns, and other harpoons and lines for walrus boats. "Chips," the carpenter, is busy overhauling old oars, and making new oars.

So if all goes well we should soon be fast in a whale, or walrus, or up against a bear.

But we strike the ice rather far east, over two hundred miles from Greenland coast! Gisbert has tried before to get into Greenland to south and west of Jan Mayen ; this time we hope to get in from farther north, about seventy-five degrees, and hope to strike Shannon Island or that neighbourhood. We have some slight hope of meeting Eskimos, and possibly musk oxen. Captain Trolle of the Danish navy was up here in 1906-1908, and charted the coast of North-East Greenland. He took command when the leader, Mylius Erichsen, lost his life in the interior. He says there is a hut on the island, one of these lonely dwellings visited by human beings once a century, generally under pressure of circumstance.

At afternoon café we overhaul cameras-like the rest of their outfit, the cameras of the Dons are of the best, as neat as can be: and we pull out all the books on recent polar work, which we and De Gisbert have between us, and discuss the writers we know.

Small floes are now on all sides, and mist. We run through one small stream of ice, shoving the pieces aside, leaving our green paint behind and some splinters on the jagged ice feet, and it is rather a sensation for my friends, their first experience of ice-then we heave to and drift. By-and-by we spot a hooded-seal and our first watch goes to the bows in the faint hope of getting a shot from board-ship, as we think the movement in the small boat would spoil their aim, and 
186 WHALING AND BEAR-HUNTING

the seal understands and pops off the ice when we are eight hundred yards off; so we retire to the cabin and the stove; for it is beastly cold and damp, and write up journals and almost wonder if we are not rather fools to come so far for such disagreeable circumstances. Still in the back of our minds we remember what a difference a little sunlight makes in a polar scene. 


\section{CHAPTER XXIV}

M

$Y$ first impressions of the Arctic ice compared to Antarctic ice are distinctly disappointing, which reminds me of my friend Dr Bruce's first impressions of the same. He had been in the Antarctic, then came up here to join the Jackson Harmsworth expedition. For several days they had been going through ice when he remarked: "I would rather like to see one of your polar icebergs." "What!" they said, "you have passed a dozen of them in the last two days. Why, there is one now," and they pointed to a piece of ice about seventy feet high, and about two hundred feet in length. Bruce was silent. I remember one of the first considerable bergs we saw in the South was over two hundred feet in height and more than nine miles long-we only saw one end of it! He had not quite realised that an Arctic berg was so small a thing compared to the majestic Antarctic bergs he had been familiar with off Graham's Land, and in the Weddell Sea. When grounded and shoved up, the Antarctic bergs are sometimes several hundred feet in height, and have, we know from soundings, a total thickness of about one thousand feet.

As we sat looking at the rather gloomy view-grey sea and bits of bluish ice-one of us spotted a black speck away down to leeward and the first watch bolted for their rifles and we steamed down. Pop-pop-went the rifles, the mausers at about fifty yards. A lucky shot drew " first blood "- a small one-year-old hooded-seal. Great was the rejoicing in our little community, and we forgot the cold and dreary aspect, and dropped a boat and the seal was aboard and flinched in no time.

Then the writer turned in for one, also Archie, and the señors made merry with a tiny drop of whisky and soda, and were very well pleased. In my dreams I heard another 
shot and the engine stopped, and we crunched up against ice, so I knew another seal had gone to the happy hunting grounds ; I showed a leg for half-a-minute, not more, it was shivering cold on deck.

Young Don Luis Velasquez had got the seal through the head, first blood for his split new rifle, telescope sight, etc.

On this almost mild morning of pigeon-grey sky, light and fine rain (8th July), we are passing through a wilderness of ice pans and small floes and the soft grey sky is reflected on the rippling lavender-coloured sea. The ice pans are mostly blue and white, like blue muslin overlaid with white, which shows almost emerald-green under the water. On the pans are fresh-water pools reflecting soft grey of sky, each pool surrounded by a rim of pale cobalt. So I wonder if there is any blue paper on board to paint on, with white body colour; that might secure the effect most rapidly. And on some of the floes are seals lying at rest, whilst others disport themselves as dolphins do in the sea, but we stop not for these, for the lavender sky is deep in colour away ahead, so we know there is more or less open water free of ice, possibly leaving a road for us to Greenland's icebound strand. That is our object, slightly uncertain of attainment, as it depends on the drift of the polar ice from the North. In some years you can make the land easilyother years it is unattainable.

We keep a sharp look-out from the crow's nest and bridge and deck for the blow of a whale; possibly we may spot a Nord Capper, or even the scarce Greenland Right Whale Balæna Mysticetus, and lift $£ 1000$ or so. We have tackle for them, but the finner whale on this trip we must leave alone, he is too monstrous strong. I have written about their capture in the first part of this book.

Here we may meet a large male polar bear, for they venture far afield. Nearer land we are likely to fall in with family parties, females and cubs. Where the seals are, there are the bears. It is a very curious thing about seals of the Antarctic sea as compared with these Arctic seals, that you very seldom see them in the South showing their heads above 
water; either they are under water or entirely out and up on the ice. I have seen many thousands there, and only remember seeing about a dozen heads above water in several months. And here again, or round our coasts, seals constantly show their heads above water. Another odd difference is that in the Southern Polar ice-seals make for the middle of the ice-sheet if they feel any alarm. They expect no harm to come to them on the ice. In fact, you can go up to them and touch them. Here they waddle off as fast as their flippers and caterpillar-like movements will take them, and get into the water for security, the reason being, that in the North they have bears and men and land animals to contend with, and neither man, bear, nor any other land animal exists down South. There the enemy is in the sea, the orca gladiator, the grampus killer, which has most awful jaws and teeth, to judge by the huge wounds one finds on the bodies of these very great seals.

All day we go under steam through the ice-floes, on each quarter a different effect-north-east there is dark cloud, with an ice-blink, a light streak on the clouds telling of a field of pack ice-ahead there is darker lilac sky, telling of open water, to our left and the south-west there is white ice and white sky, blending in a blur of soft light, so we know there is endless ice there. All of us, from the cabin boy on his first trip, enjoy the colouring, these exquisite blues and greens of the ice-tongues under water, and of the blues of the undercut ice, reflected on lavender-tinted ripples. I eagerly make notes in colour, for my recollection of Antarctic ice tints is fading. Yes, blue paper would be the thing to paint on. Is it increase of years that makes me fail to see quite such great beauty here as in the South ? I incline to think the colouring here is not quite so varied, possibly owing to the lesser variety of ice-forms. One might compare the simpler, flatter forms of the ice here and the fantastic shapes of the Antarctic, as the lowlands appear in contrast to the rocks and hills of the Highlands.

My first impression of Antarctic ice in the Weddell Sea was of bergs bigger than St Peter's, miles in length, 
a hundred and fifty feet high, with lofty blue caves into which you could sail a ship, the sea bursting up their green depths from a huge glassy swell, around them small ice like ruined Greek temples, floating lightly as feathers, such marvellous forms! Here the ice is pretty, very pretty indeed, but there is nothing awesome or staggeringly wonderful in its design.

We steamed north-westerly all forenoon; a thin haze came down in the afternoon and the sun through the haze on the ice-floes gives quite a fairylike appearance, even to our somewhat rugged figures, when we scatter over the ice-floe, which we did, and enjoyed the feeling of land, as it were.Bump! That would have upset an ink-bottle; now we lie still, up against a floe with the Fonix's nose against the dazzling blue under-cut edge, and we throw the ice-anchor and wire-cable over the bows and hammer it into the ice. Later we towed her stern round and lay broadside to the floe and put out planks for a gangway, and filled up our water-tanks from a pale cobalt pond of fresh water. We broke a bottle of champagne at this point of our proceedings -and we all agreed it tasted rather better in the snow than down South, and we shot at the empty bottle, and practised lasso-throwing, getting our eye in against a rencontre with seal or bear. Our little white ship that seemed so insignificant down in Trömso now seems to rather dominate the ice and seascape-twenty people inside the little vessel, engines, harpoons, rifles, coals, heat and food, quite a concentrated little cosmos of life and human contrivancesour all, in this wide, empty Arctic world.

Later we pushed on and the mist obscured our path again, so we tied up against another floe, with shallow lakes of pale Reckitt's blue on it. Far in towards its centre two seals lay on the snow, mere black dots, which I was about to go after, when, observing a smile on the face of Larsen, a typical blue-eyed hirsute Viking, I consulted with him and gathered it was "no use." "Hole in de ice," he said, "dey go intil!"

Stupid beasts! I thought, there are points in favour of the great tame creatures of the Antarctic which one could approach and pat on the head before turning them 
into produce for patent leather, margarine, and olive oil. ${ }^{1}$

We had a pull of about a mile in the evening in our whaleboat-three double sculls-and attempted to approach four seals on the floe edge, but they dived into the water. A young member of the party came up and had a look at us, and Archie put a very pretty shot from the moving boat into its head at about ninety yards and we pulled it aboard before it had time to sink.

On the 9th July the air and mist were still southerly, and there was nothing doing except painting ice studies, firing at marks with our various rifles and pistols, shifting from one floe to another and drifting southerly at about twenty miles per day on the cold current, that brings the polar ice and water down past East Greenland to keep the people in the British Isles from becoming too slack. Our Spanish friends are brisk as can be in the cold and damp, busy all day stripping rifles, and pistols, and cameras, and putting them up again with great deftness and neatness of hand and clever nests of tools.

At aften-mad a tiny seal (Vitulina) put its innocent little face up astern, and Don Luis boldly seized Gisbert's mannlicher and snapped a bullet into it; the telescope was sighted for a thousand yards at the time, but he got it all right.

Gisbert and the skipper in the afternoon overhauled plans for the Spanish Polar Expedition. I read some of the endless literature on the subject, and pray inwardly that I may not have to endure any more of either Arctic or Antarctic winter weather, it is the summer and the long daylight of either end of the world that I like. Heaven knows why the night was invented. The comfort of awakening at midnight to find the sun shining and no need for candles or matches is to me beyond words.

This day, the 10th July, has been more exciting - as I write we are circling round a great polar bear that has taken to the sea-we keep closing in between it and the ice-floes and it goes snorting along, horribly disgusted at being

${ }^{1}$ Seal oil is manufactured into olive oil in Paris and the patent leather is made at Dundee. 
out-manœuvred. It is our third to-day! The mist lifted a little in the afternoon-it was charming colour as it lifted and faint blue appeared overhead, and the pools in the ice were most delicate yellow set in snow of faintest pink, each pool edged with emerald. Why the snow takes the delicate tints in northern high latitudes, may someone else explain. My devoir was to attempt its colour in paints, a much more difficult thing than circumventing this poor old yellow bear that I hear snuffing and puffing over the side. My companion, Don Luis V., writes his notes beside me, and runs out occasionally to see the bear that is waiting till the gun of the watch (Don José) comes off the floe; it is his turn to shoot. Don Luis got his first bear this afternoon. We were plodding along beside a fairly big and rugged floe, say a mile in length, with a seal or two on it, when someone spotted the pale yellow object far away on the violet-tinted snow, and as it was his watch, he and Gisbert and their men set out over the floe to stalk it.

The pale yellow coat of a beast on a white floe is less easily distinguished than, say, a man in a black coat, and top hat and umbrella. But unless one is colour-blind one cannot accept its colouring as protective. I must argue this out with my friend Dr Bruce when I return to town, for I see that in his charming and instructive book, "Polar Research" (which everyone should read who is the least interested in either Arctic or Antarctic regions), he thinks the tint of some piece of ice, coloured yellow by algæ, is so like the colour of a bear that seals may be misguided enough to mistake him for yellow ice. No, no, Bruin's black nose and eyes you can see for miles, and so too you can distinguish his lemonyellow coat, almost green in the shadow with the snow's reflection.

As proof of even the bear's belief to the contrary of this protective colouring theory, he will hold his yellow paws over his black nose, so I am told, when stalking a seal; and I can vouch myself that one endeavoured to hide both his black nose and yellow body when he stalked me.

The most prominent thing on a floe, bar a bear, is a piece of brown ice, or yellow ice patch, the first coloured by land 


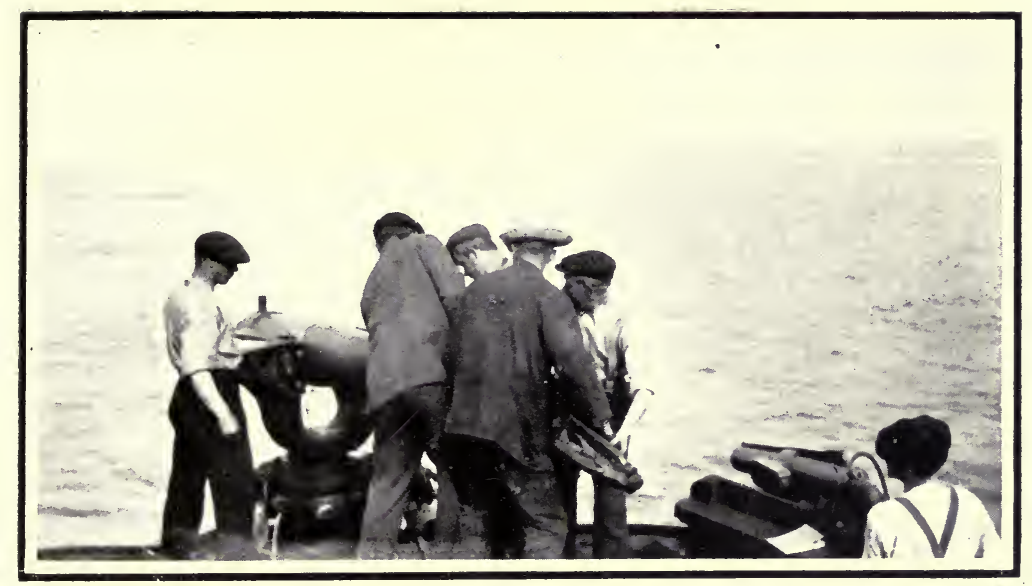

Reloading Gun with Harpoon

Note the explosive point of the harpoon is not yet screwed on.

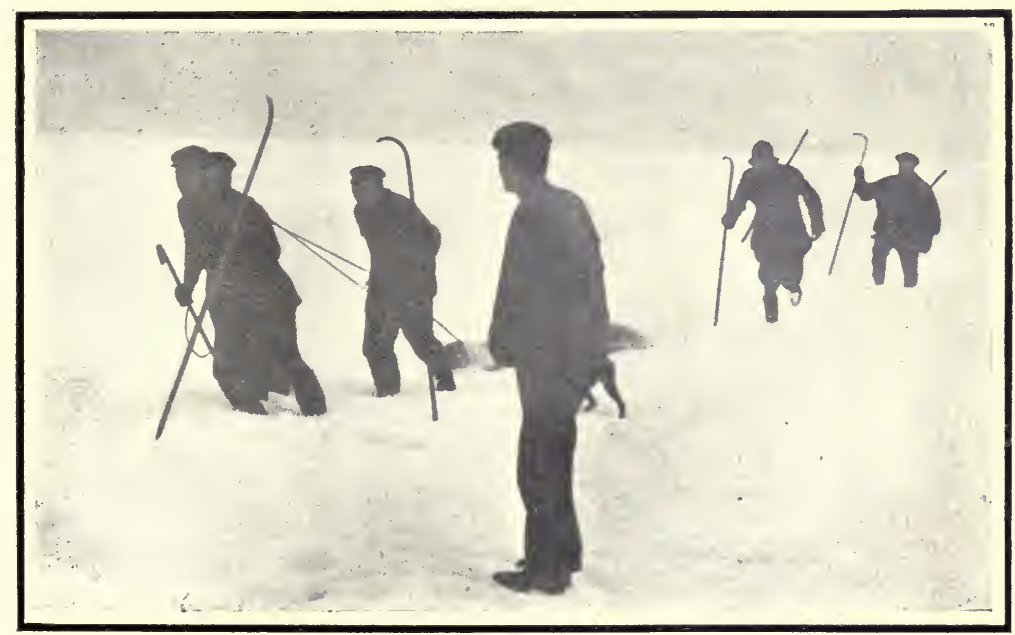

Towing Archie Hamilton's Big Bear's Skin Hamilton and Gisbert are in the rear. 

streams, the second coloured by sea algæ. You swing your glass round and round the horizon, with nothing to mark your direction on some days, when the sun is behind clouds, and keep time, and mark your place, by a yellow or brown patch. Therefore for a bear to resemble either is to court observation.

The next most interesting thing to stalking a bear, or being stalked by one, is to watch and criticise a stalk from the superior position of looker-on. It was the greatest fun imaginable to watch with the glass the little dots of figures, mere black specks, wandering over the distant floe. Of course, from your position on the bridge you can watch both the movements of the bear and the hunters, and sometimes their cross purposes make you laugh at the poor human mistakes. In this case the hunters came off best, but without the vessel the bear would have had the best of the competition. He got down wind of the group of hunters, Don Luis Velasquez, De Gisbert, and two men-sniffed the air and came hurtling along in the opposite direction and took to sea, half-a-mile from the Fonix, which we had anchored to the floe, and off it swam to a neighbouring island of ice, about half-a-mile away, so we up-sticked and headed it round till the hunters came off the floe in the boat, and the poor yellow fellow got first a bullet in the neck, which enraged it and changed the colour of the sea, then, after several more shots, a lucky one in the brain ended its charmed life. He may have left no friends, but he died without enemies to be afraid of, bar man-and we did not even find a flea on it; which was disappointing, but what was to be expected.

We think the Eskimos have met the bears here, owing to the bears' retiring manners, which are not characteristics of these polar bears in less populous parts of the polar basin. It is not a fortunate ending to a stalk to have to shoot your game in the water. Still our friend fired several shots before he got the deadly one into the brain, but there is some excuse-a heavy tramp over snow-fields after a beast that, say what you will, takes a little nerve to approach for the first time, and then the bobbing boat might upset even a very experienced shot. 
It was a great lift getting his body on board, we hooked the chain of the winch round its neck, let on steam, and up it came to the boom on the foremast, and hung dripping over the deck.

I will here quote a line or two from Scoresby's book on Greenland. He was the wonderful combination of almost a self-made man, a recognised authority as a scientist and splendid whaler.

I make this quotation to give some weight to the serious side of polar bear hunting. Nowadays it is rather the fashion to minimise dangers on land or sea. And in the time of Scoresby it was also more or less the fashion, but he frankly says: "I do not try to minimise the risks of sea life and whaling," and he gives due thanks to his Maker for many hair-breadth escapes which we to-day might put down too much to our own efforts and straight powder.

"When the bear is found in the water," he continues, " crossing from one sheet of ice to another, it may generally be attacked with advantage; but when on the shore, or more especially when it is upon a large sheet of ice, covered with snow-on which the bear, supporting itself on the surface, with its extended paws, can travel with twice the speed of a man, who perhaps sinks to the knee at every step-it can seldom be assailed with either safety or success. Most of the fatal accidents that have occurred with bears have been the result of rencounters on the ice, or injudicious attacks made at such disadvantage."

I am inclined to think that each person feels differently about approaching a bear on the ice ; depending on temperament and age. Personally I feel a faint chill-such as you have before diving off a rock into the sea, and after success something of the glow you have after you come out. But I rather think that younger people have a similar sensation before and after, only stronger. In fact, so strong as at first to make them a little pale, to upset their aim, and afterwards to make them gloriously jubilant.

The naked feeling, I am sure, is there, clothes and ordinary surroundings are of no account, there is the snow, the sky, 
and the big bear hundreds of times more powerful than yourself - and there is your rifle. Before you dive into the sea, you know you can swim a stroke or two; before you wander over the floe to Bruin, you know all you have to trust to is your aim, and your rifle.

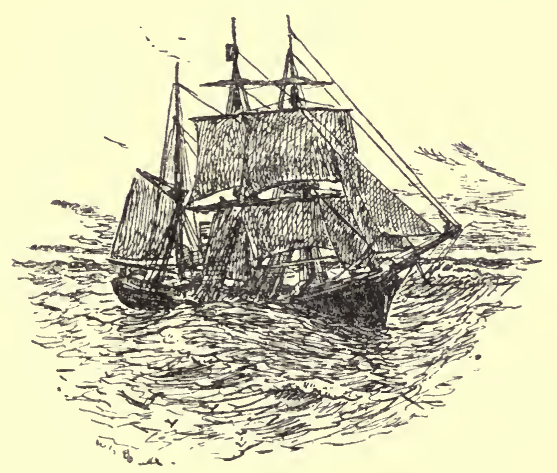




\section{CHAPTER XXV}

T CONTINUE these bear-shooting notes this evening, Friday, 11th July. I know it is evening from a faint 1 blush of pink on the snow that is just perceptible; without this I would have lost all idea of time, for since yesterday it has been all bear-hunting and no sleep. Now we have a bear alongside, all alive-o! He is tied with a rope and is swimming just like a man, hard astern, trying to tow our little whaler from the floe-edge ; and he roars every now and then in angry disgust, and then turns up his hind quarters and dives and swims a few strokes under water, only to be pulled up again on the rope or lasso. He can swim apparently without fatigue for many hours, occasionally taking a dive as deep as the lasso will allow him. We hope to get him to our Edinburgh Zoological Park, where he will be much appreciated, especially by myself and other artists and children and seniors.

He is the last of six bears in twenty-four busy hours. Don Luis Velasquez and Don José Herrero each got their first bears, one after the other, but unfortunately both were in the water. Don José's, the last, led us a very far chase over miles of floe and ice-covered sea.

The most fascinating part of the day was watching the bear's abandon of movement and joy as it did its evening saunter over the floes, utterly oblivious of our presence and probably full of young seal fat and joy; when it came across the stem of a drifted pine-it was as good as a circus. How it joked with the pine log, on its back on the snow, played the guitar with it, caressed it, then spurned it in disdain with its great soft hind foot, only to take it up in its teeth again to wave it slowly about. In the middle of this solitary play, however, the bear's seventh sense told it there was something impending and he left his cherished stick and paddled off leisurely down wind and floe-then he got the 
wind of the guns and went off pretty fast for a mile or so, occasionally stopping to sniff the breeze. At his easy rate of motion he quickly left Don José and his contingent behind-little black spots in the world of white plains and hummocks. Did the reader ever see a bear fairly out for a walk, and notice the extraordinary resemblance there is between the movements of a bear in the open and those of a ferret-shorten the ferret's body and its tail and you have something very like a microscopic bear, the long back, the way they each wave their snouts and stand up on their hind-quarters to sniff the breeze-beyond doubt, it is funny. I do not think it is really undignified, but when someone says that its movements suggest its having received a violent kick on its hind-quarters, you cannot get the idea out of your mind; and whatever its sex, or however big and powerful he may be, you must smile at the way he carries his tail down. Is their strength not marvellous? A large fellow here was waiting for a seal at a hole in the ice, and a blue seal (Phoca Barbata) just showed itself, and apparently to take the chance, with one swoop of his forearm and claws, the bear threw the great six-hundred-pound seal well on to the ice, and with a forefoot on its back, broke the head off at one bite and drank the blood and wolfed up every bit of skin and blubber; for the meat or cran, and bones, the bear, like the human, has no use, unless he is hard pressed.

Of course it is a big old bear which can do such a feat, possibly twenty years old and much bigger and broader in the quarter and shoulder than you can expect to find in Europe in confinement. Archie Hamilton got such a veteran this morning, quite comfortably, after twelve-o'clock breakfast. With De Gisbert and some men they sallied forth over the floe we were up against to deprive two bears thereon of their skins and lives-that is, if the bears did not in the first instance deprive them of theirs.

It was fascinating watching the little figures growing smaller and smaller in the distance, and to watch the soft, pale yellow heap that represented the ice-bear. I have a splendid glass, and at half-a-mile can distinguish the gloriously uxurious rolls and movements of the great fellow and note 


\section{WHALING AND BEAR-HUNTING}

the black nose and black soles of his feet as he stretches himself, and scrapes a bed in the snow for his midday siesta.

With the glass I see Archie get into soft snow and stoop and point the rifle and get up, and I wonder why, when he does this again, and I swing my glass on to the bear and notice a flush come over its yellow back, and there is a spout of red from its side; though I see so clearly I hear no sound of the shot. Five times Archie hit his Majesty, all in more or less deadly places, but he came on and girned at them and wanted to chaw them up, a fighting bear. Five 350 magnum bullets shattering bone and muscle actually knocking over the big beast, yet not destroying its fight, gives an idea of the muscle of such a full-grown snowy chief. He measured, as he lay, eight feet two inchesthat is, from nose to tail; standing up on his bare feet, he would have stood ten and a half feet and his estimated weight was one thousand and twenty pounds. As our estimate was founded on steelyard weights of many other bears and their measurements, this may be accepted as correct.

Personally, a foot or a point or two about a beast, or a ton or two's weight in a whale does not matter to me very much, it is the fun of the stalk that counts-be it for a rabbit, bear, or fingerling trout, the dew on the clover or the icicles on the berg-and how you get your beast, and what you see on the way to it, for things get impressed on memory by the excitement of a stalk, in a way they would never be at other times. If you have to crawl, for example, through a shallow blue pool on a snow-field in the early morning, as was my experience to-day, to get within shot of a bear that suspects you, you note the queer blue tint of the pool that soaks through your waistcoat-that it is sometimes blue, and sometimes purple, depending on the angle at which the light strikes the ice crystals under or on its surface. And there is plenty of time to speculate why you do not see such pools on the floes in the Antarctic.

From the ship when we spotted the bear alluded to above, and until it was killed, in fact, we thought it was very large, 
but it turned out to be not half the size of the big fellow C. A. H. has secured.

He and De Gisbert and I set out after it together. But the only way, I thought at the time, to get within shot without scaring it was to do a regular deer-stalk crawl of a hundred yards to get behind an isolated piece of rounded snow, just big enough to cover one person. So I left Gisbert and Hamilton behind a bigger hummock as covering party and proceeded at great leisure, ventre à terre, to approach the said piece of snow, I do not think that ursus got my wind, but possibly the noise of my elbow crunching through a hard crust of the snow drew his attention, and I saw a black eye and the dark ear of the right side of his face peering round the little lump of snow, then his black left eye looked round the other side of the hummock, and then both eyes and black nose were gently raised over the top-we were stalking each other !

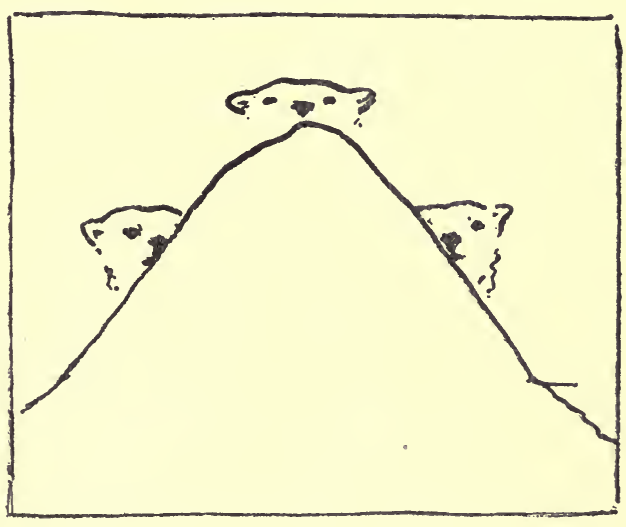

From subsequent experience I have learned that my stalking was rather wasted, as a bear will always come to the attack if you are alone. I liked his expression, what I saw of it, but either he did not like mine or he got an inkling that there was a covering party in the rear, for he suddenly seemed to think of something and turned and very sedately walked away to the left, with his head down. So I, also sedately, I hope, sat up on the soft snow and pulled at his shoulder at about fifty yards, and he collapsed, and then got up and pelted away to the right, the writer following, both of us tumbling and pulling ourselves up again in the soft snow and hummock. It took other two shots (375 cordite), both fairly well placed, to end its troubles. 
The stalk and trying to sit up on the snow crust to draw a bead on the light primrose fur of the soft-looking beast, how vividly that will make all the delicate mother-of-pearl tints of the ice scene remain in my memory!

It is a wonder that animal painters, some of them quite distinguished, do not as a rule take the trouble to go and study their animals in their proper surroundings. What numbers of pictures we see of snow-leopards, bears, and suchlike, done excellently up to a point, but with none of their natural atmosphere. The white bear with its pale primrose colour needs the shimmer and pearl-like tints of its natural surroundings, the blues and greens of the floe, veiled a little by fine snow or mist, and the hard ice, to set off its rounded soft furry form that hides such terrible strength. How could anyone, for example, hope to paint a caribou, with its glory of russet horns, unless he has seen its grey face and white neck amongst silver birch stems and the red glow of maples?

To do the ice-bear justice, you should first splash on to canvas the shimmer of mother-of-pearl, then inset the comic kicked-on-the-hind-quarter figure in yellow, give the humour and preserve his strength and majesty at the same time, so you'd have a masterpiece. At a school or zoological garden or museum you can learn anatomy and painting, but outside work is essential for the true animal painter. There he must forget bones and muscles and get the envelope of air and colour of the animal and its surroundings.

But to come back to our bear-hunting. As our party returned from the hunt, the men spread out left and right, covering about a mile, and so roped in a younger bear, which had been hanging about to leeward of the old male bear which Hamilton shot. Why it did so we cannot say. It was cheery work for the men, running about as beaters sometimes do at a drive when a hare gets up and tries to get back. It was a little shy of them, but did not seem to mind the ship; in fact it came right up to us and we got a boat down. It then tried to run down the floe edge and outflank beaters, but Larsen, a long, fair-haired, blue-eyed fellow, got ahead and fired bullets into ice in front of its nose-range about 


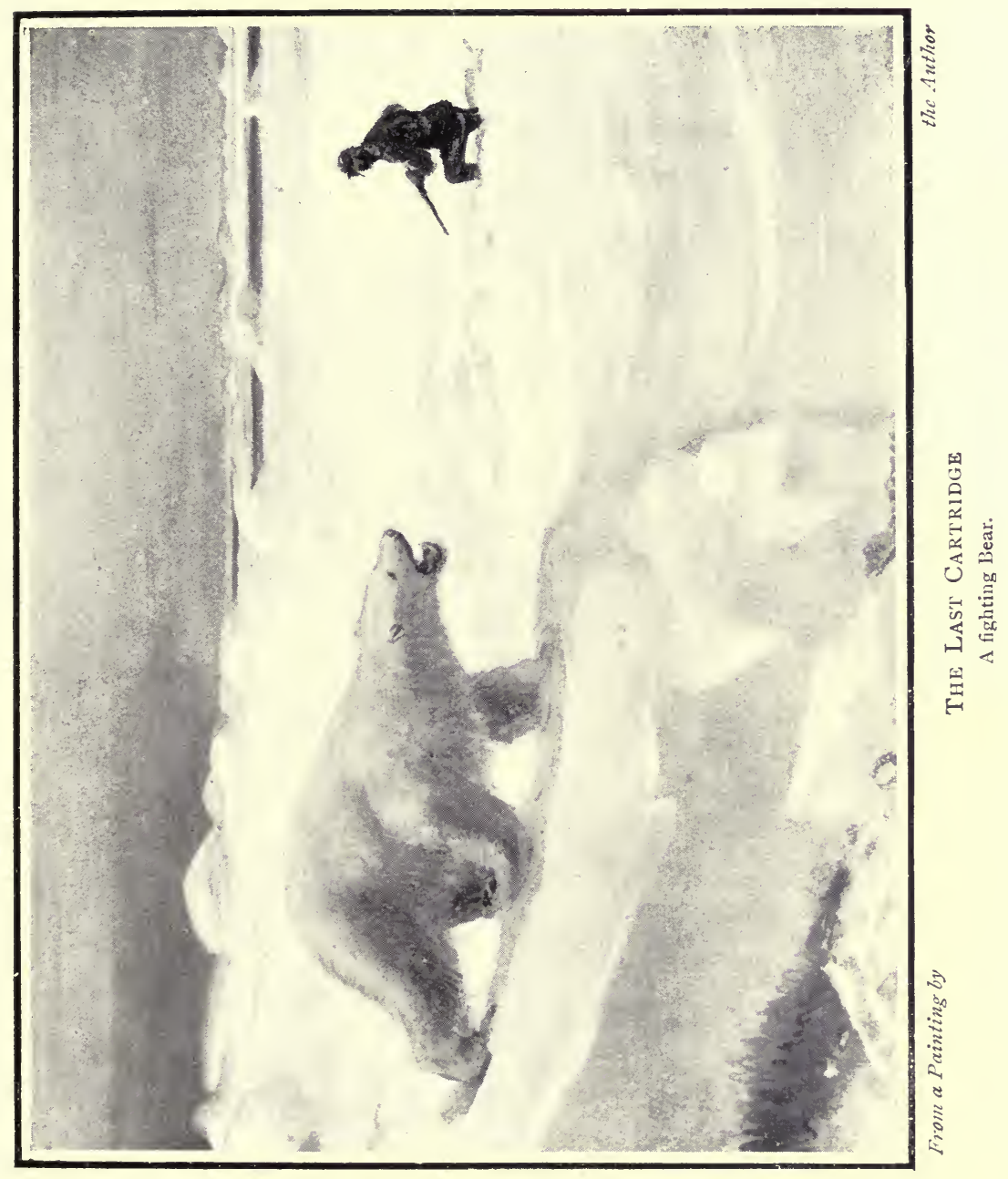



four yards, and it got disquieted and turned back to the ship, then slipped over the floe-edge into the sea, and we rowed after it, and a sailor made a dozen poor attempts to cast a lasso over its neck; he bungled it over somehow and we towed it, using dreadful language at us, alongside, and afterwards got it on board into a cage.

I think this recapitulates our bearing for twenty-four hours rather concisely. It does not quite convey the slight chill you feel at setting out, on however beautiful and silvery a morning, at, say, five o'clock, after being up all night, to wade across ice and snow to face the horrible and dangerous Ursus Maritimus, or white monarch of the pole, and it does not give the calm sense of conceit that you feel when you have succeeded in slaughtering the same, and preserving your skin; it would be bad form to express such sentiments loud out. The only sign our Spanish friends showed was that they were a little sallow when they set out, and a little warmer in colour on their return. A. C. H. quotes Neil Munro to express his feeling. "Man," he says, "am feeling shust sublime-could poo the mast oot o' the ship an' peat a Brussels carpet." No wonder, lucky fellow, a one-thousand-andtwenty-pounder for his first polar bear. His first black bear we thought mighty big a year or two ago, away back in the barrens of Newfoundland; it weighed three hundred and eighty pounds. Which is best to eat, polar or black bear, it is hard to say. I vote for black bear pre salé and fed in the blueberry season. Still, the meat of the polar bears here is extremely good and feels strengthening. One needs strengthening. Yesterday was high summer, just touching freezing, but still and a little sunny; to-night a gale from north-east and cold, and ice driving gently round us.

But I am not complaining! No-I've been a summer and autumn in Antarctic ice. After the bad days and black nights there in January and February, nothing north of the Line need be considered as intolerable.

One note before winding up this day's reckoning. If you wish to think of the Arctic or Antarctic, you must think in colour somehow or other. If you think in black and white you miss the idea, and form a wrong impression all in black 
and white, just as I used to have from engravings, and which it is very difficult to put aside. North Polar and South Polar regions are essentially places of very high-toned delicate colour, almost the only black is what you bring with you; mother-of-pearl and birch-bark tints you have, and grimness there is in dead earnest, dangers and minor discomforts, but it's all in lovely colour in high note.

It is my watch and Gisbert's to-night, but I am going to turn in after writing this; two nights without sleep make

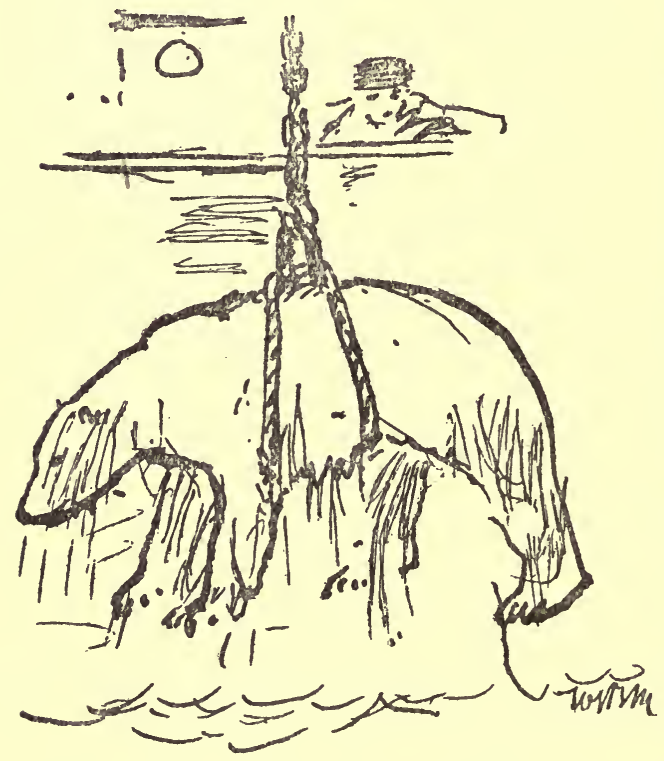

one feel inclined to ride out this gale behind a floe in one's bunkpipe, matches and book, and practice chanter, all within arm's-length, and jolly comfortable it is ; for, as Marcus Aurelius puts it: "If a man can live in a palace, he can live there well."

I forgot to say we got our Bruin on board, after a terrible fight and some blood lost,

human and bear's. We got a strop round his waist when we had pulled him alongside with the lasso, and hauled him up in the air by the steam-winch, the chain and hook fast in the strop. I think this little drawing explains the method; it's a most kindly and considerate treatment. I mention this to ease the mind of some people who concluded that a picture in this book of a bear hung by the head was a live bear being lifted on board instead of being a bear that had been shot for an attempt on our lives on the ice. Whalers and sealers and bear-hunters I have found 
just as humane and gentle a people as those who stay at home and often criticise them unkindly. We led the lasso under the floor bars of a big wooden cage which we made to-day; three men hauled his head down. Then we lowered him into the cage, and whilst he tried to free his head, battens were rapidly nailed on over his back. So he is on board, but not all right, it is quite possible he may pull away a batten tonight. He is busy carpentering, and has already got one spar off. I would prefer his going overboard to looking me up in my bunk.

It blew all night, so we all rested and had European breakfast at leisure at nine. I did a picture of a bear I saw yesterday, Archie's bear. It is munching the head of a young hooded-seal, Cystophora Cristata, of which we saw over forty in one lot yesterday. I also did a picture, from notes at the time, of the jolly lonely bear playing with a piece of driftwood, lying on its back and tossing away the wood with his hind foot, just before he got up, suspecting there was something in the wind, and before going off over the floe down wind at that easy gait that leaves poor man such miles behind whenever there is soft snow to negotiate. 


\section{CHAPTER XXVI}

$\mathrm{N}$

O whales yet, never a blow, no chance to use our harpoon-guns from the ship's bows or from the boats, so we keep their covers on. What patience is needed for whaling! Two seasons ago a friend of mine, a captain of a Dundee whaler, was up this north-east coast of Greenland with a big crew for three months, and got only one whale and one bear. Then, with luck, you may get several in one day, I have never yet seen more than three killed in the twentyfour hours ; but I have done nine months' whaling with three whalers and killed none! That is rather a record.

. . . The wind is easterly, the worst we could have for getting in to North-East Greenland, for it is driving the floes inshore. We are once more anchored to a floe and wait till the weather clears, for it is too windy and misty to make good progress. We are still about seventy-five degrees north and a hundred and thirty miles from the coast, and there is an unusual amount of ice between us and it, so we may not reach it after all.

Whales at last! Narwhals! the fellows with long ivory horns. The steward spotted them first as he was cleaning a dish at the galley door; he came running aft with a blush of excitement on his face, and we saw their backs, three of them, and dashed for the whale-boat, but before we got away the whales had disappeared! It was ever thus. They are the most illusive whales. "A uni, a uni," I have heard our Dundee whalers shout down south in the Antarctic, and they too disappeared without scathe.

But are there narwhals in the South, you ask. Well, this is all I can say, our men said they saw them. I did not. Their word "uni" stands for unicorn or narwhal. 
De Gisbert's experience is similar; he has only killed females with small horns or no horns. But with the beginner's luck, a friend of his in his first season in the Arctic - Count Thurn-got one with an immense horn of splendid ivory; we must have patience then. Does the reader know what they do with these horns? No one here can give a definite opinion. Scoresby, the celebrated English Greenland whaler and scientific observer, suggests that it may be used for killing fish for their food. He found a portion of skate inside one, and as they have small mouths and no teeth, he concluded the horn must have been used to kill the skate. His undoubted ability and his education in science in Edinburgh University give considerable weight to his conclusion.

The little excitement of narwhal-hunting broke the stillness of rather a monotonous evening of mist and fine rain. Pretty enough, though, for a little sunlight penetrates the mist, giving the snow the faintest warm flesh tint, a pleasing contrast to the green and blue underside of the snow blocks on the floe to which we are anchored. We can study these delicate snow tints through our cabin door, as we sit at meals, always hoping that a whale may blow in the still water, or a bear may cross the delicate tints of the middle distance. Our language at table is in Spanish, French, and Norwegian. Archie and I sometimes speak in our Doric for a change. The talk is generally about whaling or hunting of various kinds; here and there, east, west, north, south, Norway, Alaska, Bohemia, Arctic or Antarctic, with a certain amount of more or less scientific discussion about natural history and the elements. De Gisbert is the hub or centre of the party; he drops from one language to the other with the greatest ease. We talk a good deal about the coming Spanish National Polar Scientific Expedition which he is to lead, and to which the writer is asked to give a "Scotch escort" to a point with an unpronounceable name east of the Lena river; no polar sprint this, but a serious effort to read the inmost secrets of the North Polar basin, by every means known to modern science. An attempt to find answers to all the riddles put before mankind, the why and wherefore 
of tides, ocean currents, temperature, colouring, electrical currents and air currents-information about subjects we know a little of, and, possibly, secrets of nature not yet dreamed of.

Then we turned in early for us, for last night's damp and mist and the quiet of the sea seemed to make us somnolent, so by twelve o'clock we were mostly to bed, except the steward, whose galley is next my bunk. He and the first mate and cook, a female cook we brought from Trömso, were having a quiet concert. They made a group like a picture of the Dutch school; the steward in half light, in a white jacket, trolling out an air to the guitar, our jolly, beamy vivandière and the mate sitting opposite, almost (or as you may say, quite) on each other's knees in the tiny quarters, cups, dishes, and vegetables round them.

The steward, Pedersen, was pathetic to-day about the vivandière, he noted a chip in a cup at breakfast and gazed at it mournfully and sighed: "She is so mush too sdrong dis she-cook of ours." She is strong, and red-cheeked, it is true, and very beamy and has a laugh and a word for everyone. She was one of the few who were not sick coming over from Norway, and though so broad and strong, she nipped about between the seas like an A.B., and laughed when the cold sea-water came up to her knees. I back Norwegian shecooks against the field.

I have written down what a tricky musician is this steward, he keeps a music shop in Trömso in winter, his wife and kinderen look after it in summer, when the midnight sun appears, then he attends princes and humble people like ourselves, who go in search of whales, or adventures; or scientific data to this " end of the garden," where you have sun and winter in midsummer, fog, snow, drifting ice-floes, sun, heat, cold, huge energy, a great deal of beauty, and astounding repose. But why this restfulness here? we all did at least eight to ten hours last night. Neither the writer, nor De Gisbert, nor some others of our party ever do so much at a spell down South. And at any time in the twenty-four hours one can be awake or go to sleep with equal facility - appetites go up wonderfully, we simply wade 
through bear steak. I noticed the smallest of our Spanish friends, who would blush to face a whole egg in Madrid on a July morning, calmly got outside four this morning, each with its slice of bear; he has slept a good deal since. We consider that he is a pucca shikari and also a born actor; it is pure joy to watch his movements of hands and face and body as he and Gisbert jestingly argue out a subject. He told us last night how the wine tasters in South Spain can throw a glass of wine into the air in a thin stream, and catch it all in the glass again as it falls. You see he is showing how it is done. He threw up a glass of pontet canet, but instead of falling back into the glass it all went down his neck and wrist. We laughed some, then he dried himself and went on to show us something else, every now and then popping his head out at the cabin door to see if anything was stirring on the ice-floes.

Some of my friends plan making a great sanatorium up in these latitudes on claims which we have pegged out in Spitzbergen,

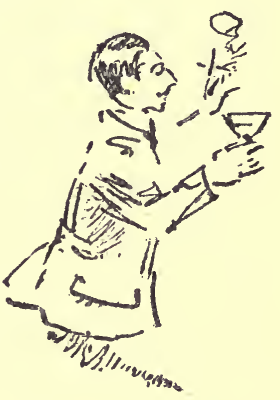
so that people who cling to life may go there to get rid of tubercular complaints. There is not an atom of a germ there, so people with chest complaints recover there on the land. But you can have persistent colds on board a vessel, I suppose because of germs belonging to it. Some vessels seem to breed a plentiful supply. I know a vessel that carries colds for all hands on every trip. It is, I believe, somewhat similar with scurvy.

We got a very ugly brown shark this morning, one of those deep-sea Arctic sharks (Squalus Borealis) that do not follow ships, but live away down fifty fathoms deep and possibly eat cod. Why he came up it is hard to say; possibly he scented seal. We welcomed him with a harpoon as he swam alongside, and got a running bowline round his tail, and slung him alongside, head down, till he nearly died. He was only ten feet eight inches, a rough brown ugly beggar, not so fierce-looking or active as those blue sharks we killed last year, off the Azores, for eating our sperm-whale blubber. 
There is a Norwegian fishery for these sharks, for the oil contained in their livers, which is used largely in commerce as cod liver oil; chemically it is exactly the same. These sharks are too big to pull on board the fishing-boats, so they are only hauled alongside, when the liver is cut out and the stomach is blown up with air, and stitched up ; so they go off on the surface ; if they went deep down their relatives would eat them and neglect the Norwegians' baits. The vitality of this shark's flesh tissue is remarkable. After this one had lost its whole machinery, its flesh still lived, and after its head was off, both flesh and head moved. A seal I shot this morning, after rather an interesting stalk over soft snow and blue lakes, shot clean through the brain, showed the heart beating a long time after.

I once wrote rather a lurid and perhaps too colourful a picture of seal-killing, in the South, and the paragraph has been made use of by people who will not eat flesh, but wear boots, and they showed how cruel sealers were, and wished to stop them killing seals-honest fellows, risking their lives in Antarctic ice and Newfoundland floes to keep their wives and children in life at home. The seal may lose its brain with a crashing shot and then its skin and fat for olive oil, or for our chair-seats, shoes and salads, but that it feels pain after the shock, or that the sealers are to blame, I deny.

Our port white bear at any rate approves of the seal and shark killing; he hates the wooden cage, but doesn't he swallow the seal's blubber which we squeeze between the battens, and he simply laps up the sharks' foie gras in heaps. He gave me such a scare this morning; I had forgotten his presence and was counting the toes on a seal's hind foot for pictorial purposes and examining the formation of the dead bears' heads quite close to his cage, when he let out a roar within an inch of my ear. I confess I was startled ! He is only three to four years old, still he probably weighs well over three hundred pounds and has a voice according.

To shoot a seal this morning I used De Gisbert's telescopesighted mauser rifle, a new experience, the accuracy is marvellous and up here that is necessary, as seals are wary. Down 


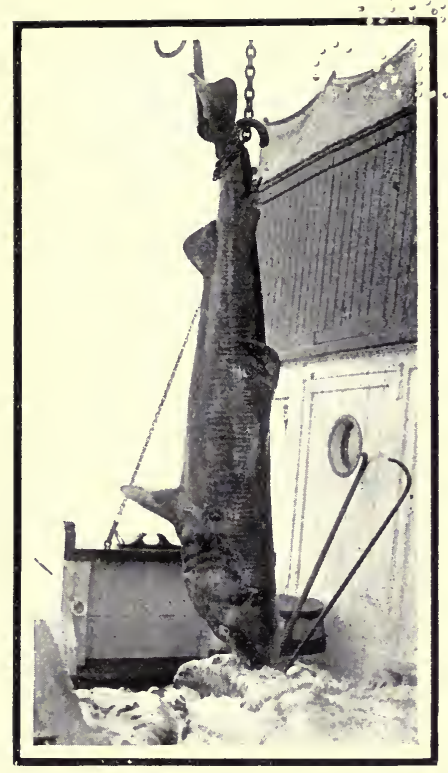

Photo by

C. A. Hamiiton

ArCtic Shark, Squalus Borealis

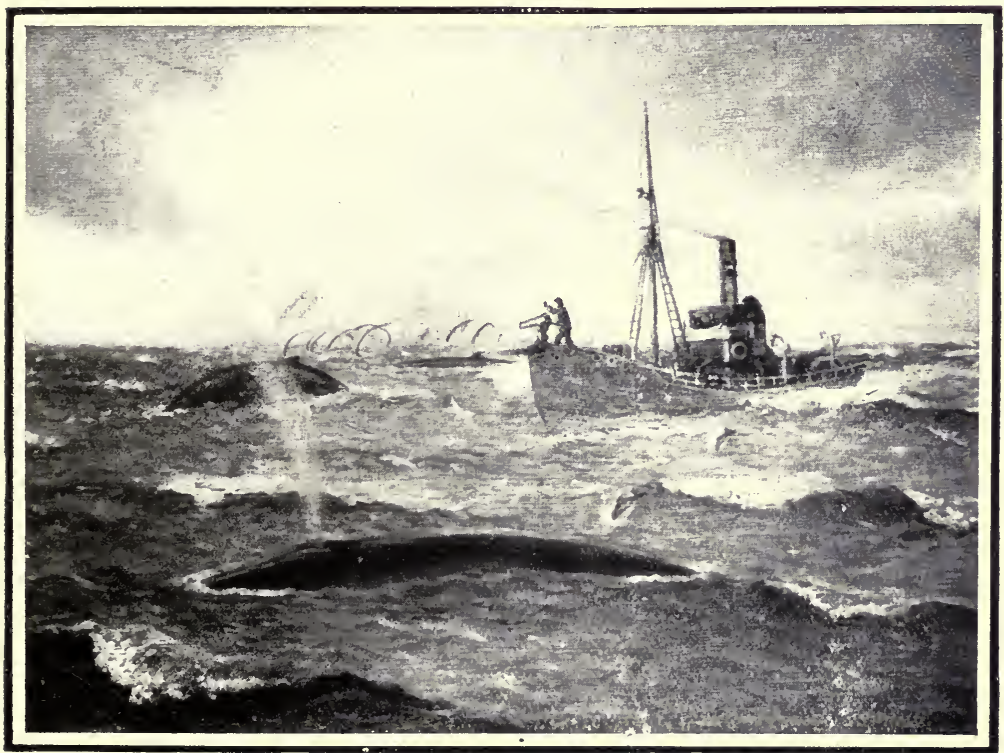

From an Oil Painting by

the Author

A Moidern S'team Whaler

The harpoon has just struck a Whale. The Dolohins give a sense of proportion of the Finner Whale. 

South you pat them on the head if you like before you shoot; they do not mind your presence in the least. I find wading stockings are perhaps better than sea-boots for these melting floes, as you go sometimes over the knees, in the blue water pools and in the soft snow. Also you can turn them inside out to dry, which you can't do to sea-boots.

The seal was fairly large and had three or four awful gashes, of a foot or two in length, which were put down to either a bear's teeth or claws.

It snows to-night-it is dead calm, broad daylight, but cold and no sun visible, floes all round and our hopes are going down; we fear we may never see Greenland's icy mountains and the saxifrages and poppies that I have set my heart on seeing. So we sat and sat in the silence and made belief that time was passing all right, and quite enjoyed a small excitement. A squeak-I would not call it a squeal-from our "too-strong she-cook." She was cutting up a piece of shark for our dinner, and suddenly noticed that it responded to her touch-sentience of matter, you may call it. I felt it was most unpleasing for some reason-it was quite white flesh like halibut, and lay in a small block on the bulwark rail, and when you touched it it gave a squirm or movement of say a quarter to half an inch. We all collected round ; and at supper we ate it, some of us did-I did notat least only the tiniest morsel. It began to feel rather dull, so I suggested to Gisbert we should get the foils out and we would fence on deck in the falling snow, and Archie would photograph us and we would send the result to "Lescrime," and we were just buttoning up our leather jackets for the fray, when young Don Luis Velasquez put his glass up at our cabin door and spotted a bear on a small floe not three hundred yards away, eating seal. We thought it was probably the sealskin and blubber of my morning's seal, which we had let go adrift, owing to the sores the bear's claws had left on it, making it dangerous for the hands engaged to skin it. Pusey finger we called the wounds in the Antarctic which we got from cutting up seals that had been torn by a grampus. Though colds are rare in Arctic regions, and consumption is said not to exist, yet often sores 
take long to heal ; cuts on the hands, for example, often take a long time to grow fresh skin.

So our quiet Sabbath evening became all excitement, and we dived for rifle, pistol, and lasso; the lasso because we could see the bear was not full grown, possibly a three-yearold, and we hoped we might get it alive. As we raced down -four oars in the whale-boat-I endeavoured to get some of the frozen stiffness out of the rope and got it into coils in the bow, and before I had completely done so, we were down wind and near the bear. It stared at us and made rather a sudden and alarming approach to the floe-edge, as if it intended to come on board. I expected to lasso it on the ice, but it plunged into the sea and came up within ten yards. At the first throw the loop dropped neatly round its head and sank a little, and a hard pull and a turn round the bollard or timber-head in the bow made the bear fast. Cheers from the men and roars from the bear, and Gisbert's congratulations; he was surprised at such a cast from his pupil. (But he was not half so surprised as I was.) It was very pretty as it stood looking at our approach in the boat, faint yellow, darker than snow; two black tashes for eyes, one for nose and two dark marks for ears, and the red of the seal's flesh and skin on the snow-very simple colours, very delicate pale emerald-green and blue on the ice. When it came running at us it was too picturesque! We towed it alongside the ship, gnashing its teeth and roaring, where it swam about, expressing its disgust, in language I dare not quote, at the rope round its neck and its inability to tow the ship away. It may be too big and strong for us to manage on board-probably measures eight feet from nose to heel and is three to four years old; six-month cubs are what we can handle more easily, and even at that age they are wonderfully strong. Gisbert told me he lassoed a cub, and was throwing an extra hitch round its forearm, when it got alongside him, put one hand on his chest, and he went down like grass, and he is short and very strong, and is quite fourteen stone; he got his arm rather badly bitten. All hands set to work to make another strong timber cage, and they had it done almost before $I$ had made a picture of the 
bear as it looked at us approaching in the boat, and long before Ursus showed any fatigue from swimming and roaring.

Then there was wild work in the boat getting the strop round its waist-oaths and foam, and flying ropes-donkeyengine-roars from the bear-shouts from the men-steam, and bear's hot breath, all mixed up. But out it came, only as strong perhaps as two or three wild horses, and we managed to drop it into the top of the cage, hauling its head down with the lasso rove through the bottom bars of the cage, and banged down battens on top, with great eight-inch nails driven in, by six or seven strong Vikings, Gisbert leading and having all they could do. Then we cut the lasso and he was free of the loop in a second or two. So we have two live bears now, possibly polar cousins. The first is to port, the second to starboard of main-hatch, and their deep voices give a strong accompaniment to our progression. They have no qualms about eating; they tear the timber of their cage and eat seal's fat from our hand alternately.

It is my early watch to-day, three A.M. to nine A.M., till welcome coffee-time. There is nothing doing, no whale's spout and no bears appear. Still one never knows, so Olaus paces the foredeck with his hands deep in his pockets and Larsen works away quietly at the bear meat, taking off every bit of the fat, so that it will be good for our table. I write in our little chart-room on the bridge, with a view all round of floes of ice extending right round the horizon; we are anchored to one-in its shelter. The wind is falling and it is very quiet; there is the lap, lap of the small waves against the green edge of the floe, the tweet, tweet of some ivory gulls, and the homely barn-door-fowl-like cluck, cluck of the fulmar petrels, as they squabble and splutter under the stern for scraps of food, not forgetting the frequent low, deep growls of the bear we lassoed last night. His companion, our first capture, is asleep, possibly dreaming that it is free, poor fellow! So I study my immediate surroundings without interruption. A flight of ivory gulls has just come and has lit beside us on the floe. They are white as this paper and yet not quite so white as snow ; they have dark beaks and feet and black eyes, so what you see when they stand in 
order on the pinkish white snow is a series of almost invisibly yellowish white upright sort of sea-birds, which you would not notice at all, but for their dark legs and eyes and bills.

If there happens to be one of the pale blue ice ponds just beyond them, then you see them white against it distinctly, and the blue is reflected under their bodies as they stand beside the pool, or when they rise and flit over it it shines under their wings. They always stand bills up wind, as if they had come from somewhere and expected something, but are not particularly anxious about it. They do not seem to be excited about the flesh we throw into the snow at this early hour; later they all start to eat it at once. The fulmars seem to eat all the time. These yellowish white birds with chalky-grey and brown wings are always with us, round our stern, battling ever about scraps of seals' blubber; there is quite a homely farm-door sound about their cluck, cluck. Seamen say they are reincarnated souls of men lost at sea-rather a far-fetched idea, to my mind. Then there comes a Richardson's skua. We need a specimen for Edinburgh Museum, so I drop it on the floe with no compunction; it is the sea-birds' pirate and has a touch of the cuckoo's plumage under its wings. It neither reaps nor sows, simply lives by cheek. When a simple fulmar has filled itself with what it can get, fish or fowls or little cuttlefish and minute shrimps, by dint of hard work and early rising, then by comes Mr Skua of quick flight, and ingeniously attacks the fulmar from behind and underneath, till it disgorges its breakfast and the skua catches it up before it reaches the water!

Though our ice-scape is very remote and far afield, and subdued in sound and in colour, there is a great deal going on. At the floe-edge there are reddish shrimps in the clear cold water, and if you take some of the water in a glass, you will see still more minute crustaceans, a joy of delicate coloured armour under the microscope. And there is inorganic life amongst the ice; a blue block has just come sweeping past very slowly-it is like blue and white muslin. But big life, bar our three selves on deck this morning, there seems to be none. All the rest of our crowd are sound asleep 
below decks. I think they should be up and doing, for the sky is lifting and the snow ceased and there is more and more animation amongst our bird neighbours. The ivory gulls find it is breakfast-time and suddenly set to work, pecking at pieces of meat they barely glanced at an hour ago. There is a promise of movement-possibly of our finding a way through the purple leads, through these sheets of ice-floes to Greenland in the west. Yes, there is more colour now, the white night is changing almost unnoticeably, and the ivory gulls begin to call before they take another flight (they speak just like our sea-swallows or terns, a tweet, tweet). On first seeing an ivory gull you are not greatly impressed; it is simply an entirely white gull. But you recall Arctic travellers mentioning it, and the little pause they make after its name; and when you see them yourself you realise what that means . . . that little creamy white body that reflects the grey of the sea under its wing, or the blue in the pool on ice-floes, its inconsequent floating white flight is the very soul of the Arctic. As closely associated with the ice-edge there is another white bird in the Antarctic, the snowy petrel, a delicate white spirit bird, a never-to-be-forgotten touch of white delicacy in the almost awful beauty of the Antarctic floe-edge, a small bird, white and soft as a snowflake, flitting amongst white and Doric ruins on the edge of a lonely sea. Here the white counterpart is a larger, a more material creature on the edge of a shallower, less impressive ice-pack, but the kinship is there.

How I wish it was breakfast-time! two more hours before our " much too strong she-cook" will give us frokost.

At this point in these meditations we came across another bear; we had let go our floe and were heading north-west, the day clearing (bump! that was ice), when we spotted him on a small floe, across which he sped at a good speed. At first we thought it was small enough to take with lasso and keep alive, so we chased it, but it proved on close acquaintance to be an old she-bear, and far too big and strong to rope, so we dispatched it with my 38 Colt pistol with one shot in the centre of its white head at ten yards, which killed it stone dead, much to the astonishment of crew, who 


\section{WHALING AND BEAR-HUNTING}

had no idea of what a pistol can do. Not an hour later, still before the longed-for breakfast, we spotted a big bear on a floe to windward, just five minutes after our watch was up, so it came in the watch of Don Luis Velasquez, who came on at nine o'clock.

It was fascinating, watching the great beast with the glass as it sauntered to and fro on the floe, a seal lay on the floe not far out of the line from windward, and we fondly hoped to see the bear stalk it, but before it quite crossed the line of scent, and when not a hundred yards from the seal, he evidently thought he would like forty winks, so he shovelled himself a lair in the snow and turned in, but it was not quite to his liking, so he got up and looked towards us, and either did not see our rigging or did not mind it and lay down again, so that we only saw his great yellowish back above a snow ridge. So Gisbert and Don Luis had time for a tiny whisky-and-soda, but no breakfast, and set out with a large camp-following, and we others went on with coffee and bear-steak, and at our leisure went to the bridge and watched their long walk over snow ridges and wreaths and blue-water pools. The ice-bear looked up when they were about two hundred yards distant and began to come towards them, then thought there were too many, and retired. He was pretty well peppered by both rifles before he gave in, fifteen to twenty-five shots we heard-the account varies, but he was hit several times. When you are by yourself, or with only another man, the bear will face you and come to the attack, so you get a better chance than when it is inclined to retire, as it did in this case. This was another male of large size. I made a jotting of him before he yawned and lay down to sleep, he probably had breakfasted-at least he did not notice the seal distant from him about twenty yards.

There is much bumping to-day-floes are heavy and close and we have to charge some which makes the splinters fly from our sheathing of hard wood. It seems more hopeless than ever to reach the North Greenland coast. The floes are so large and numerous, we fear that even did we do so, a little easterly wind might hem us in on the coast against land ice, 
where we might have to stay indefinitely. Still, two days may alter the aspect of ice entirely: Svendsen details all this to us with the stump of a pencil on the white wood of our new captive's cage to which he puts his black nose and ivory teeth and crushes splinters, now and then using his claws. He must know us all now, but they naturally are not very friendly yet and the deep, musical vibration of their growls coming right aft from the waist, sound sometimes a little like curses " not loud but deep." We can stand that, but when the note changes to something like "For the Lord's sake let me out," to freedom and the wide floe, we have to harden our hearts and think of little children at home.

At lunch we talk bear and other sport and Arctic cachés. The last a subject that is fascinating. The first I ever heard of was from one of Leigh Smith's men of the Eira. We were in the tropies, he was steering when he spoke of it, with longing. He had wintered with Leigh Smith in Franz Josef Land before that part became popular, and as he steered he told me how, before leaving for their forty days' voyage in an open boat to Norway (they had lost their ship in an ice squeeze), they buried the spare rifles, musical instruments, and champagne. How one's teeth watered as we heard of these "beakers, cooled a long age in the deep delved" snow, and little did my companion Bruce or I ever think we would be near that caché; but five years later Bruce was up there, and found the rifles, musical-boxes and champagne bottles were there, just as described, but alas the bottles were burst! Gisbert tells me he also saw the same caché ten years later, and he knows of a finer one still, still untouched by the $\mathbf{A}-\mathbf{Z}-$ expedition. It is also in Franz Josef Land-a cave in rock, blasted out, and covered with a timber door so thick that not all the polar bears in the Arctic, good carpenters as they are, could open it. That is the Duke d'Abruzzi's caché, and there are others; one, I think, on Shannon Island, which we aim at getting to and which we will add to, if not in need of provisions, and draw on if we are in distress. The idea is to add to such a store if you can, for the benefit of anyone really in need. It is a wicked thing, however, to draw on a caché, 


\section{6 WHALING AND BEAR-HUNTING}

excepting in case of being in want of the necessaries for existence. I have had one pilfered in the barrens of Newfoundland of tea and sugar, raisins, chocolate and such luxuries, the necessaries, flour and hard tack, being left untouched. Were the man found who did this, his life would be made a burden to him through the breadth of Newfoundland.

But to come back to our ice-bears. I have lately, and at other times, heard many stories about them, and the more I see of them the more do I believe about their strength, and timidity, their fierce courage, and docility. One bear does one thing, the next the opposite. One dies with two or three bullets whilst running away, the next eats them up, advancing to the attack.

Gisbert's closest contact, bar the occasion before mentioned with the young bear, was quite exciting and unexpected. He left the ship one day to verify the height of a mountain in Franz Josef Land, which he had previously calculated from sea-went up a steep ice-fall with ski in tow and got to near the top, when a fierce gale, with snow, started. Following the bear's plan, he looked for a hole to slip into, found such a shelter, and crawled in. By the faint blue light. coming through the ice roof and sides of the cave he discovered a great bear, with its black nose resting on its folded paws and its dark eyes looking at him with a kindly expression. He did not trust the expression, but, keeping his eyes steadily on the bear's, he gently pulled his rifle forward, and without lifting it, with his thumb pushed back the safety bolt, and slowly brought forward the muzzle to the bear's ear and pulled, and so Gisbert lived to tell the tale. It sounds a moderately tall story, but after many others I have heard, and even from what I have seen lately, it does not sound so wonderful as it may to one who has not been at "this end of the garden." When the gale blew over, some of the crew came up to his signal, and three all told, slid down the slope on the white bear's body, at the foot it was, of course, deprived of its skin; when you think of it, the whole proceeding seems rather hard on the bear.

Another bear yarn I heard from my friend Henriksen, whom I have written about in previous chapters on our 


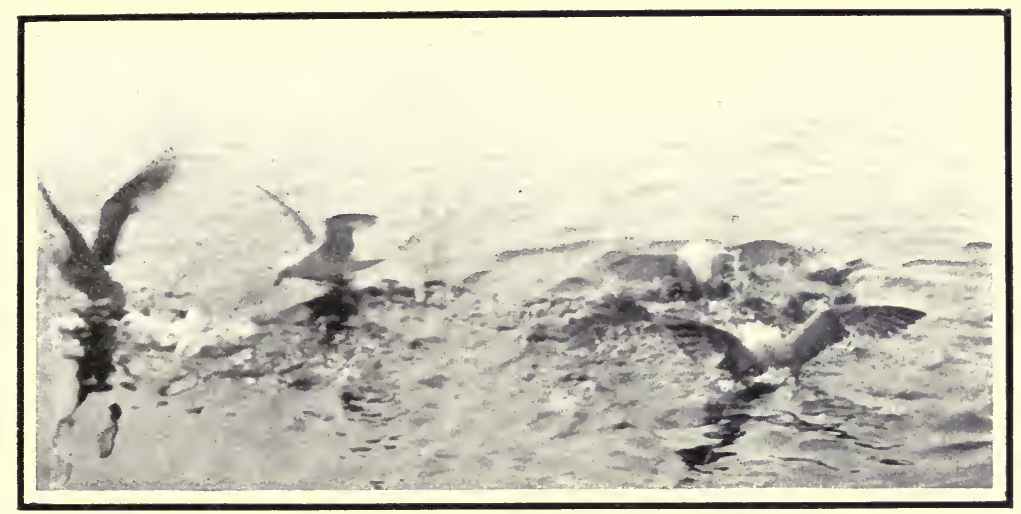

Photo by

Fulmar Petrels

C. A. Hamilton

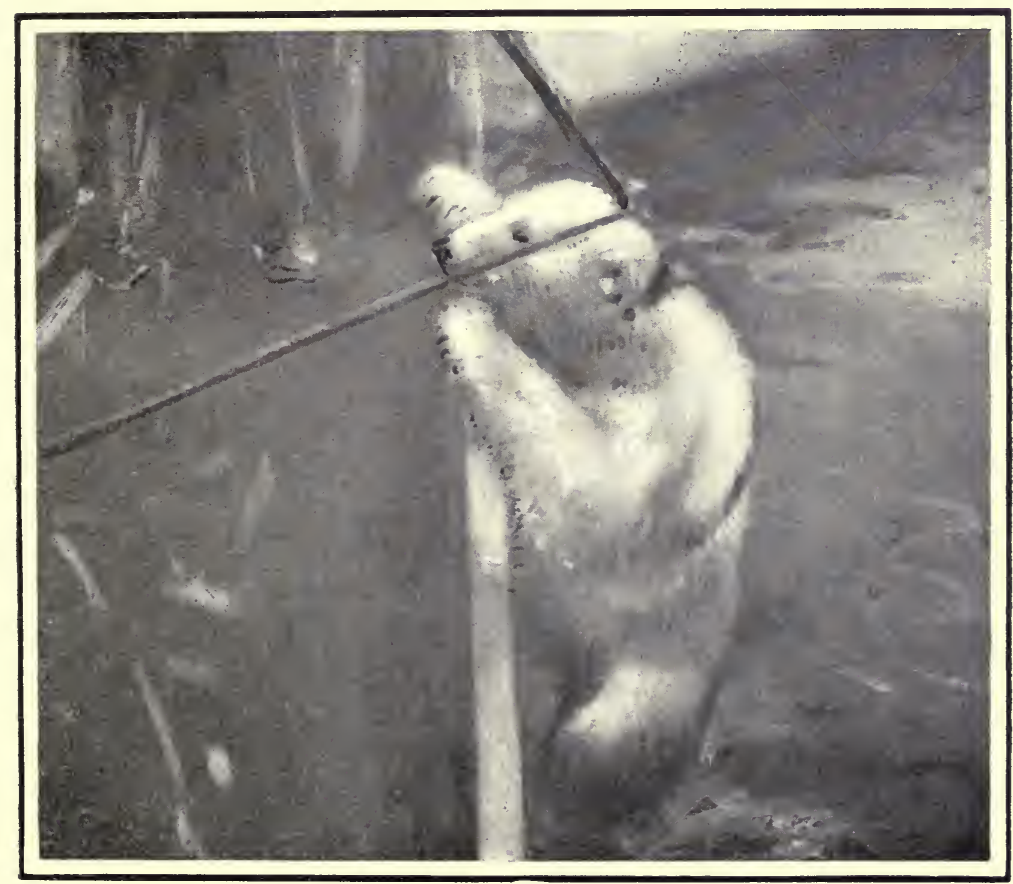

"Starboard" Being Hoisted on Board by Steam Winch 

whaler the St Ebba. His father used to go north, and once took a farm hand from his home in the island of Nottero. Hansen was no sailor, and was a little weak-minded, but enormously strong physically. In the fo'c'sle, the crew made him their butt, till one morning he rose in his simple wrath and threw the crew out separately up the scuttle on to the deck when they should have been at dinner, and kept them out till they pleaded for mercy. Shortly after he became their hero, for one day whilst they were all away on the ice sealing they were signalled to, to return to the ship, for the ice was breaking up, and all hands made a long run

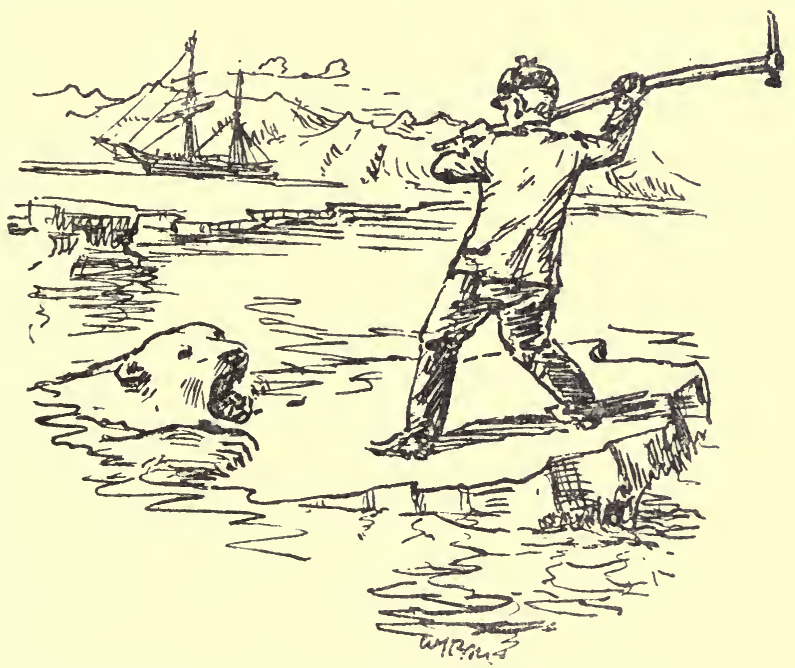

round an opening lane to get aboard, but big Hansen hooked a piece of floating ice and started navigating himself across, paddling with his ice pick, and he was not in the least put out when he observed a big bear awaiting his landing. But the bear seemed impatient and shoved off to meet him halfway, and Hansen quietly waited and dealt it a mighty blow with his pick into the brain as it came alongside, and killed it, then towed it along with him, skinned it, and came to the ship with its head and skin over his head and shoulders, very bloody but very pleased.

Last night we were fog-stayed, we could not get ahead a thin fog with the midnight sun shining through. We 


\section{WHALING AND BEAR-HUNTING}

had many small things to occupy ourselves with, but every five minutes some of us were out at the cabin door to look at the view. Only a plain of snow fading in violet ridges into the mist, with very few features, but the delicacy of the colour you hardly notice at first, day after day grows on you, and if you try to paint it, it grows more quickly, and you realise the difficulty of trying to reproduce Nature's highest quiet notes. It was our watch till three-that is, Archie's and mine-but the others stayed up, though there was little chance of seeing a bear. So inside the cabin we piled coal on to the small stove and blew smokes, and it was warm, distinctly cosy, and the guitar thrummed, and several of us hummed and wrote and smoked, and then went out into the cold, frosty air and looked at the colour, the fantasy of ice form and colour and the icicles hanging from scanty rigging, and came back to the cabin and vainly tried to find words to express appreciation of the beauty of the white scenery.

So we stayed up till the end of our watch, then Archie and I turned in, very sleepy, and our Spanish friends stood their watch as well, till nine. They never seem to turn a hair for want of sleep. 


\section{CHAPTER XXVII}

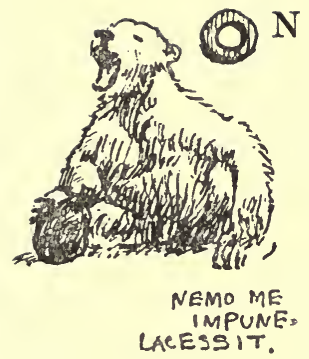

the 15th of July we started looking for whale or bear in the mist again, but with never a sign of either. So painting was the order of the day for the writer, such a chance, no letters, no newspapers, nothing to take one's mind off looking at the effects of this end of the garden. Hours flew, middag mad of bear passed, painting still going, only interrupted by expeditions forward, where our men were packing the bear and seal skins in salt in barrels. Later we went ashore-i.e. on to the blue floe-blue ice covered with white crystals, you might call it snow. Three of our party and the dog, a young Gordon setter, wild with joy at freedom of movement, they go off a mile or so over hard, smooth surface, which grows more and more faint in the sunny haze and distance. The surface on this particular floe was smooth and hard and easy to walk on. In most places you see the light coming up as through a carpet of white crystals on pale blue glass beneath your feet. Where there is a little water it is quite blue, and where it is dry you shovel your feet through loose white crystals on the top of the blue. So this is rather different from Antarctic floes, which, as far as I can remember, were covered with fresh snow, so the walking was generally more difficult than here. Before I had seen northern floes my Dundee whaler companions used to tell me how they often played football matches on the northern ice, and I wondered ! - now I understand. I also believe now what I doubted, that whilst doing so one misty day, Dundee sealers against Newfoundlanders, referee, silver whistle and all in great style, a bear intervened and took their walrus bladder football; what a sweet picture in greys that would make, the sailor-men bolting for the ship, their 
dark clothes look so delicate and ethereal on the floe in this fine mist, and to see a bear's faint yellow coat in contrast!

Our party came back towing a drift pine stem which we had spotted far off on the ice from the mast-head. Quite an important find in the wide world of ice. They towed it to the ship with a lasso.

Gisbert and the writer did quite a lot of lasso practice, partly at a stick set in ice, partly at our dog, as it ran to fetch a glove-great sport for us, but the dog soon showed a desire to climb on board by the rope ladder. As we cut off the ice-worn root with our ice axe we discussed the possible journeyings of the pine stem ; from its roots we knew it had grown on rocky ground, from the rings, its slow growth and age, and consequently of the climate it had survived in; from the known currents and drifts we calculated it came from far-away eastwards, say from the Lena river in Siberia. When tired of lassoing, De Gisbert showed me something about splitting logs. I am not a great expert with an axe, and he is rather, he cut his sea-boot soon almost through the leather of the inside of the instep without cutting his foot. To show him what I could do, with a mighty welt I split a $\log$, and the axe glanced and cut my instep through the seaboot and two pairs of stockings. A chopped tree and a chopped foot may not appear to have wide or deep interest to anyone but the owner of the foot, and may not seem worthy of record in such Arctic notes as these. But let us pause and consider, if there is not something wonderful and almost inexplicable in this apparently trifling incident. Here you have East meeting East, North meeting North! A " gentleman of Scotland born" proceeds by a devious route from Edinburgh via Hull to an ice-floe in the North Polar basin. And here, from some unknown river in far Siberia, possibly the Lena, by the great polar current, after possibly years of voyaging, comes this lonely barkless pine stem, and they meet. And the gentleman chops the extremity of the tree with the ship's axe and his own extremity at the same timenamely his left instep, as before mentioned. Does not this incident, though trifling in itself, recall the divine words of the Immortal William: "There's a divinity that shapes 
our ends, rough hew them how we will." Perhaps, without any claim to originality, we may, under the circumstances, be allowed to conclude, from the above combination of circumstances, that the world is small.

So the snow had other red than the bear's. Gisbert got his " first aid " out within a second of the time I had got my own, he is very quick: but the captain was first with his, and Archie administered a small tot of medicine from three bens and three glens which he had brought in a little flask all the way from Arthur Lodge, Edinburgh. It will be a sell if I cannot go on one foot after the next bear or whale.

About these North Polar basin currents we have many interesting talks, for De Gisbert has studied them for many years. He has asked me to accompany the Spanish expedition in the vessel which will accompany his Spanish Government ship as far as Cape Tsdieljulskin. This possibly because as an artist he is so well content with trying to depict effects of his "end of the garden," most possibly because his, Gisbert's, wife and child are to go so far, and as she is a Campbell-Gibson she naturally dotes on the bagpipes.

At night the mist cleared up a little and we made some miles to west, pushing through floes. When we came to a blue fresh-water pool on one, we again set to work and bailed our tanks full of fresh water.

Then on again, charging the floes with many a bump, which is rather alarming to those of our party who are not salted to such shocks. We hope the floes won't close up behind us altogether, but when you enter the pack, as the whalers say, "there's no looking over the shoulder," and one must take risks in all occupations.

To-day we had a splendid bear chase, none the worse because our prey escaped. The morning was exquisite, the mist rose and lay in lavender wisps across the distance of the floes, and the sun shone and the sea became a cheery glittering dark blue, and you could hardly keep your eyes 
open when you came out of the cabin for the blaze of light. What a change, everything sharp and clear, compared to the veiled misty ice effects of last week!

We were at breakfast and would have liked time for a pipe before the news came: "An ice-bear!" and over the bows on to the floe by the rope ladder five of us scrambled. The writer was armed with a heavy double 475, and cartridges the size of asparagus, said to be unnecessarily heavy, but Hamilton's last monster bear took five of his 355 magnum, all in pretty good places. It seems to me that a really big bear would be more surely killed by a heavy 475 or $500 .^{1}$ Bad luck it was to have to travel with a cut foot, and doubly bad at the very start to make a false step and go

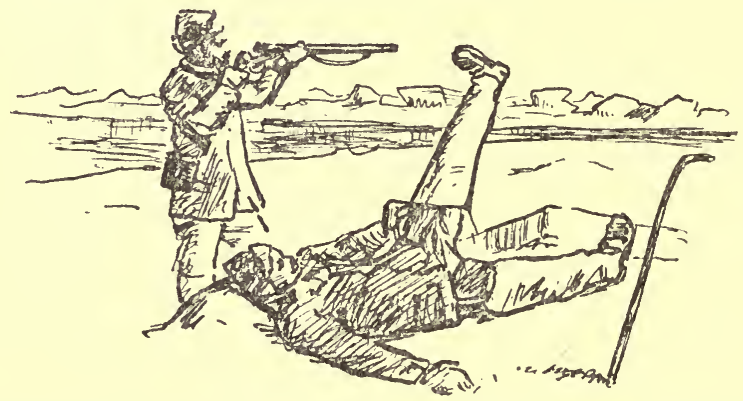

head first into a hole in the floe, and to get wet through, with waders full at the start. However, Archie cleverly caught the rifle and gave me a hand out, and I got rid of some of the water in the way all anglers are familiar with-that is, lying on your back and holding up your feet, a few "tut tuts," and we proceeded over hard snow, when we could get it, wading blue shallows from time to time. Two of our seamen went flanking about a mile out on to the floe and we beat up half-a-mile from sea-edge, aiming at the place where we had seen the bears from the crow's nest, a female with two cubs. The chill of the early start, cold water and the soreness of the foot wore off as we slowly covered mile after mile; sometimes walking was merely a struggle, soft snow covering blocks of ice with horrid pitfalls, other times over

${ }^{1}$ Not proved. The smaller 250 bore and higher velocity seemed to us all to be most effective and stopping. 
crisp, glittering, sunlit beds of icicles set in blue, level as a mat, tumbling into glittering fragments as we crunched across. But our trail was all in vain; from blocks and hummocks we spied the plains and could not find our bears. They had made a wide circuit, gone down wind, and got ours, I expect, and had gone clean away, and as the floe was, say, twenty miles across and all over hummoeks, they were soon lost to sight, even from the mast-head.

Coming back at leisure we had more time to enjoy the warm sun and the colouring. There were three distinct blues. Behind our little white ship at the floe-edge the sea glittered deep blue, like Oxford blue; on the floe between us and the ship there was spread a wide pond of shallow water, lighter than Cambridge blue, and the pigeon-grey sky showed patches of light peacock-blue.

A change of clothes, a redressed foot by Captain Svendsen -one of the lightest handed surgeons I have met-and some bear-steak and we started steaming round the floe, pretty sure of getting our glasses on to the bears before many hours were past. For hours we watched with glasses and telescope from the bridge and crow's nest the passing white and grey plains and snowy fantastic rock scenes till we almost slept with the continual concentration of the eye on the moving white scene. But alas, at five P.M., the mist came down again, so again we put our ship's nose against the icefloe and we pray now that the mist may lift. The skipper and Gisbert took advantage of this pause to make an Artificial horizon with tar in a plate, and tried to find our position by same with sun on the tar surface. But the tar congealed off the level, and after calculations in decimals, yards in length, we find our position is two hundred miles inside the northeast coast of Greenland !

Before midnight, with the sun still high above the horizon, the mist lifted and again we go plodding round another huge floe. We cannot get west yet, enormous floes bar our way, there is a narrow passage, say two hundred yards wide, to west between two counties of ice, but it is too narrow for us to venture through. Should the floes close we would be imprisoned before we had time to retreat. 
It is almost incredible, there is a feeling of movement today, the 17th July, quite a perceptible sense of pitch and roll. You notice it even without looking. The living movement of the sea-for ten days we have been "in the ice," with smooth water. How welcome is this open water. A clear road lies before us to Greenland-why should the ice this year lie across our track in such fields, making us take fifteen days for a distance we expected to cover in four? Perhaps it was as well we met it; though there were no whales there were at least bears, so we have their valuable skins and seal blubber, and our two live bears to make up our cargo. They bring rather an unpleasing aroma at times into the pure Arctic air. Their cages are in parts becoming more and more thick, with stumps of the two-inch battens, which they have eaten their way through. We begin to wonder how to get one of them across from Trömso to Edinburgh, for it would be awkward if they eat their way through on a passenger steamer. Mem: Keep on practising lasso and throwing hitches and pistol practice.

At three this morning, twenty minutes to three to be exact, and in Don José's watch, we spotted a bear on the great floe we were hanging about yesterday; a bear and two cubs, probably the bear of yesterday, and he and Gisbert went off armed cap-à-pie, and the writer could not but be amused at the old lady's cleverness, though it was at the expense of our companions. It was a mile away, but with a fine glass every movement could be followed, and with no glass to aid its sight it could apparently follow our movements. It stood up its full height, craned its neck to one side or the other, then got on all-fours and spoke to its cubs, and they set off up wind, then it turned round, took another spy at our friends, who soon looked like little black dots amongst the waste of floe, ice hummocks and pinnacles, little lakes and shallow valleys, and as they pursued their way steadily to where the bears had been seen, it made a wide sweep to their left and got away farther even than we could follow it from the mast. I made a jotting from the telescope as per over page, which gives an idea of the kind of going. 


$$
\begin{aligned}
& \text {. }
\end{aligned}
$$

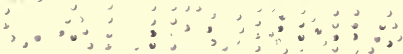

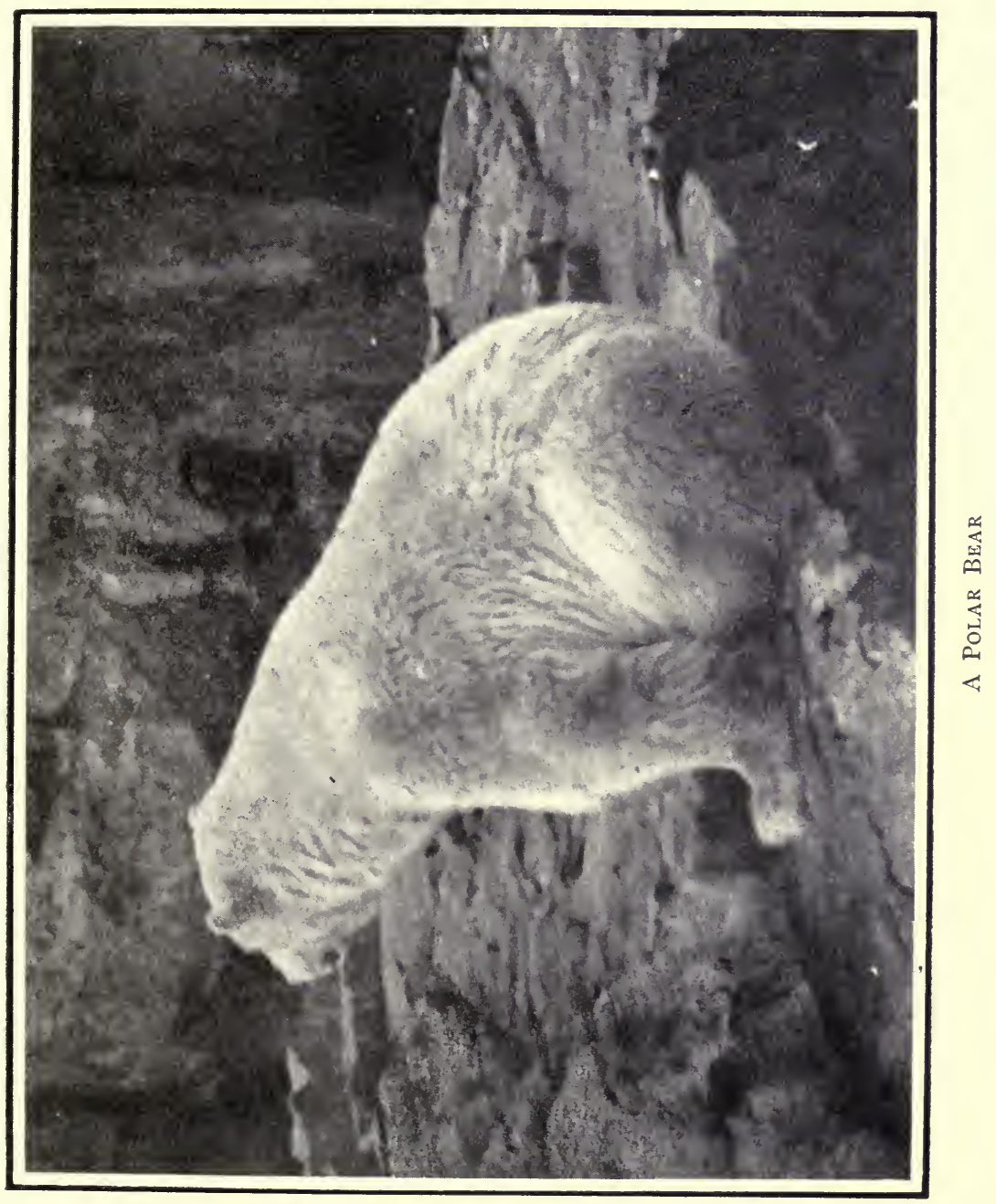



I would know that long cunning female again, I believe, were I to meet her, from the odd movements, from her " outstretched neck and ever watchful eye." The cubs should be grateful for such a mother; without her skill in characterreading, they would both be in little cages on board here! Does it not make the reader comfortable to know that they are at liberty, free to enjoy seal-killing and fat galore, and pure snow and air and the Arctic world to roam in ? When they would not follow fast enough Mother Bear turned and spoke angrily, then finally went and spanked them. A bear and a monkey are the only animals, excepting man, who spank their young. So up here you see little domestic touches in bear life, which, so far, you cannot get in a zoo. It is worth coming north to see such a matron tending her young, to see the jolly round yellow cubs full of fun, gambolling over the fine old mother, playing with her ears and head and teeth that at half-a-bite could take a man's head off like asparagus. Here is a picture of such a group. "Rest after Play," it should perhaps be called. "True till Death" might be too harrowing.

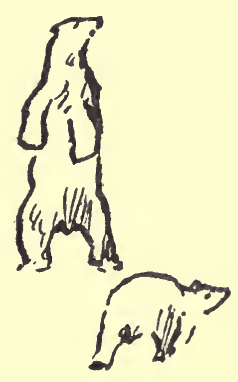

Sometimes fatal accidents occur in bear-hunting. I have heard of several, but they are small in number compared to the number of bears shot. A few years ago Gisbert witnessed one. Two Norwegian sealers came on an ice-floe after two bears somewhere east of Spitzbergen, and they killed one and set to work skinning it. The second bear was holding towards Gisbert's vessel, so one of the Norwegians hurried off to annex it by himself, which is not a very safe thing to do. He pursued it some time and wounded it, and the bear went for him, and his rifle jammed, and when De Gisbert's party came up a little while afterwards the man was in ribbons.

Now I hope we may stop writing about bears and soon come in touch with our older friends, the whales, of one kind or another. We are prepared for Balean whales, or Nord Cappers, "the old kind," I call them. But for the big 


\section{WHALING AND BEAR-HUNTING}

stronger Finners we are not prepared. I have written about these in a previous chapter-about the special tackle required to master their enormous strength. "Modern whales," I call them, or Finners, the largest animal that exists in this world, or ever has existed, up to one hundred and twenty feet; longer than the prehistoric Diplodocus. The Balean whale or Mysticetus that used to be fished here, and which has grown so scarce, though it is generally depicted destroying boats, is a fat, leisurely "fish " compared to these bigger and more active Finners, but alas, he is now not only scarce but is also very shy and wary.

Forty-five miles we plod along, with northerly strong wind, and pass two of what they call icebergs here- "ice chips" down South-a grey sky ribbed like sea-sand overhead, with the light off snow land on the sky; a yellowish cold glare to the westward; that is Greenland, and we at last pull up against the land-floe. It is just the same as the big seafloes which we have been amongst, still it is against the land ! Twenty-five miles of it we guess; when the haze over it lifts we shall see Greenland's icy mountains. The days of heat and basking in the blooming saxifrage and yellow poppies seem still far away. But patience-if you wait for ever so long you sometimes get your heart's desire.

The strong wind from north and west is cutting off bits of this land-floe of all sizes, from a yard wide to a mile or two, and so taking them down to cool our north temperate zone. I wish the process had begun sooner, so that we now might be nearer land in shallow soundings looking for walrus. I sincerely desire to see them, as I think my heavy 475 would have the chance of its life as against the smaller bore rifles we have with us. You have to shoot them, then harpoon them before they sink; when one is harpooned the others rally round and there is wild work. Whales, musk oxen and walrus, coupled with a bee humming in the Greenland meadows, is my desire. It is said there are mosquitoes, but for none of the breed have I any desire, either little or big, from Bassein Creek or Seringapatam. They do say, however, that the Greenland specimen does not have any fever on its proboscis. 
Whales at last in our night watch! I must write my notes about them before I turn in. Some people say whaling is not sport. I differ from them. It is the best sport I know. We had bear and whale in the same basket to-night, first a cast for a whale which went off, and then immediately after a shot at a bear which we got, and then another whale, which we got also, both within two hours. Certainly though it was only a narwhal the whale was the best sport.

We lie in a small bay the length of our small vessel, which is one hundred and ten feet in length, and to our left hand there is a bigger bay in the floe, about two hundred yards wide, and narwhals have appeared in it. So we dropped our whale-boat with the harpoon-gun loaded and put the line in order. This, of course, should have been all in order and ready, so time was lost. Then we tumbled on board by the port chains and rowed down to where the whales had last appeared; and waited for them to come up again.

It blew a little with cold, fine snow. As we waited someone on board shouted "A bear!" and we cast our eyes down wind to the ice-floe and got a glimpse of pale primrose passing amongst hummocks; and very quickly we got the harpoon out of the gun and backed down as fast as possible, getting into a bit of a sea, and as we approached the floe I got two 475 shells into the rifle. As we came within fifty yards up came Bruin, making towards us. It was very difficult to hold straight, for the sea was breaking in foam and the boat was tossed about amongst chunks of ice, so I held on and on, wishing to make sure-up and down we went, and round went the muzzle of the rifle, but still the bear came on, as if he wanted to board us. So lest he should change his mind and bolt, I let loose at about eight yards and tried to hit the middle of its chest, but I was a trifle off and hit the point of his starboard shoulder-with such a heavy rifle and big ball and cartridge we would have expected to knock him over, but it only turned it! The second barrel hit him a little high and back of the shoulder, and he tumbled out of sight over a hummock. So we made wild jumps on to broken ice 
in the foam and scrambled on to the floe and over very rugged hummocks for a few yards, and put in a third shot, which seemed to finish it, and Svendsen and two men hurried on to get the body, for the ice was closing round us, but they found it still breathing, so Gisbert and I, who were keeping the boat off the floe-edge, backed in again, and with difficulty handed the rifle to Svendsen, who put in another bullet, and with a rope the three dragged it over the snow towards the boat. It was a mighty drag even for the distance of a hundred yards. Then we backed in again through the surf at ice-edge and Svendsen and the men struggled into the boat with the line, and we hurriedly pulled and shoved off, for some heavy ice was closing round us, and got out just in time, with the bear floating in tow. In the rough water clear of ice, we managed, with another struggle and without upsetting, to pull the bear on board and rowed back to the ship, greatly rejoicing! Just as we got it heaved on board by the steam-winch, much to my relief, I spotted the narwhals again and off we set, three pairs of oars rowing hard, and as quickly as possible, the harpoon again in place.

I have been at the killing of much bigger whales, but this spotted black-and-white fellow with the horn in his nose, plus the bear, was to my mind as interesting a little hunt as any. Sometimes a rabbit stalk is of more interest than that of a deer! A fine black-and-white-spotted fellow showed with a great ivory unicorn, but out of shot. Then another, more brown in colour, appeared, and Svendsen let drive. The harpoon shot was excellent and very quick, away went the line, I do not know for how many fathoms-we passed it aft and all hauled in and let out and hauled in again, finally we came alongside the whale, with its circle of splashing and foam, and it raised its tail, and we put in a big bullet from the 475, which went from its stern to its bow, and it collapsed instantly. It was a surprisingly killing shot, for one bullet to kill the whale, and yet the bear took three to stop it. We hove our line in short, and set to work to tow the whale alongside and began to flense it - that is, to strip the blubber off the carcass-and were 
all very pleased, and were just drawing the harpoon from the gun, which we had reloaded, when again whales appeared in our little ice bay. So we again threw our oilskins into the boat and went off again. In our bay we waited twenty minutes by the watch, and up one came again, a better one than our first was leading: it was white, with black spots. Our first was brown, with white markings. We very nearly got the harpoon into it, but it only showed for a second or two each rise and it escaped. So more waiting in wet cold wind, with a lot of bears' blood, and snow and water under foot : but this journey we had each a tot of aqua vite. So we waited and waited again, just as you wait for a rising trout-only with a little more subdued excitement and perhaps more than usual wet and cold : and again the handsome beasts appeared, and we dashed after them, three pairs of oars, but they went off under the floe and we waited again till endurance ceased, and, very wet, and cold, and shivering, we got aboard for supper at four in the morning. Three

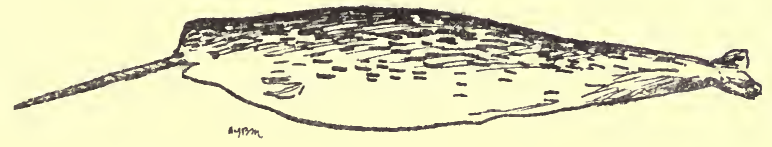

o'clock yesterday morning till four o'clock this morning makes a longish day of experience. I would have given two bears to have got the biggest narwhal with the splendid horn. Perhaps if we had harpooned one of the baby whales of the family we might have got the horned male, for narwhals, like sperm whales, stand by each other. Or we might have had his great ivory tusk through our boat, as has happened before. They have driven their spear through many inches of an oaken keel. You can see such a keel in Bergen Museum.

We cut up the narwhal and found it full of small cuttle-fish and shrimps-the bear was full of lead. These great 475 cordite seemed to have less effect than the higher velocity $\mathbf{2 5 0}$ mannlicher. I must try them again, but I begin to be a convert to the smaller bores and high velocity. 
230 WHALING AND BEAR-HUNTING

Now it is Archie's turn for another bear, so I can retire to paint and bring up my game-book with four bears and a whale to enter-two bears with rifle, one with lasso, and one with pistol, and possibly the whale which was partly killed by harpoon, partly by rifle. 


\section{CHAPTER XXVIII}

T F I had not been writing these notes I would have harpooned a whale, I believe, for a few minutes after getting on board the narwhals appeared again, and by the time we were afloat and at the place they had appeared at, we were too late. So, to be out of temptation and the cold, I turned in at six A.M., after a long day of the unexpected. First, open sea! then the narwhals' appearance, then the bears, and narwhals again. Quite good hunting if it were not for the persistent mist that worries all of us more or less and prevents our getting ahead.

I hear this morning that after I had turned in, the mate had a shot with the harpoon at a narwhal and missed. I am sure our gun shoots short, possibly the powder is faulty. I have known a man miss fifty shots in succession in the Japanese seas, owing to this cause. He got more suitable powder, and he killed sixty-nine whales without a miss.

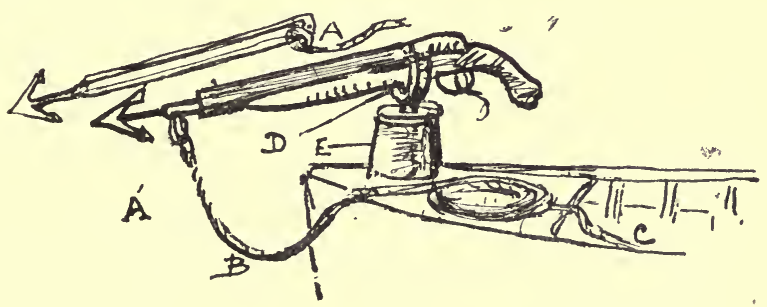

This is the old style of gun and harpoon which we have on the Fonix. A is wire strop or grummet running in slot in harpoon shaft. B is the " forego," a length of extra fine and strong line attached to harpoon. $\mathrm{C}$ shows the line going into the bottom of the boat. D, crutch turning in; E, a bollard or timber-head.

On the Balæna, a Dundee and Greenland whaler I was on for a long cruise, we coiled down eighteen hundred yards of two-inch rope in each boat, extremely carefully 
coiled down in three divisions, one in the bows, one amidships, and another at the stern. After using the modern heavy Finner tackle from a small steamer these old lines seem to be very light tackle in contrast. Last year we coiled down five-inch ropes (i.e. five in circumference) three hundred and sixty fathoms to port, three hundred and sixty to starboard, each line filling a bulkhead of, say, eight feet by eight, and each line weighing about a ton, and the harpoons weighed nearly two hundredweights. To play a fish of, say, ninety tons that can snap such a cable or tow your hundred-foot steamer at eight to fifteen knots up wind, with the twohundred-horse-power engine doing eight knots astern, is some sport. But the thin lines we have here are quite adequate for this Balean whale of the Arctic, for the Right whale as a rule does not sprint and it floats when it is dead, and usually, on being harpooned, dives deep and stays down till it exhausts itself from want of air, and so the lancing is easy. The rorquals go off at great speed nearer the surface.

Does the reader know about the great Svend Foyn, who invented the harpoon for the great finners of modern whaling ? He was a man of remarkable determination and strength of character. Many yarns have I heard about him.

This is one of them :

To show how his new harpoon worked, he took his wife on a trial trip-great man as he was, he made mistakes, and had his limitations. He soon made fast to a great finner with his new harpoon and line, and was he not a proud man? But the harpoon struck the whale too far aft and did not disable it. It took out the whole line and with a rush took their little steamer in tow at a terrible speed out of the fiord for twelve hours at fifteen knots against a gale, and they were steaming seven knots astern with a sail up to help to stop the speed.

"Let go, let go," prayed the wife, "I am seek, I am afraid." "No, no," said Foyn, "I vill never let go. I vill show you veech is de strongest my vill or de vill of de beasts," and he held on and finally got the whale lanced. But it was an awful fight. When they towed the whale ashore in triumph his wife was nearly dead, and she said : 


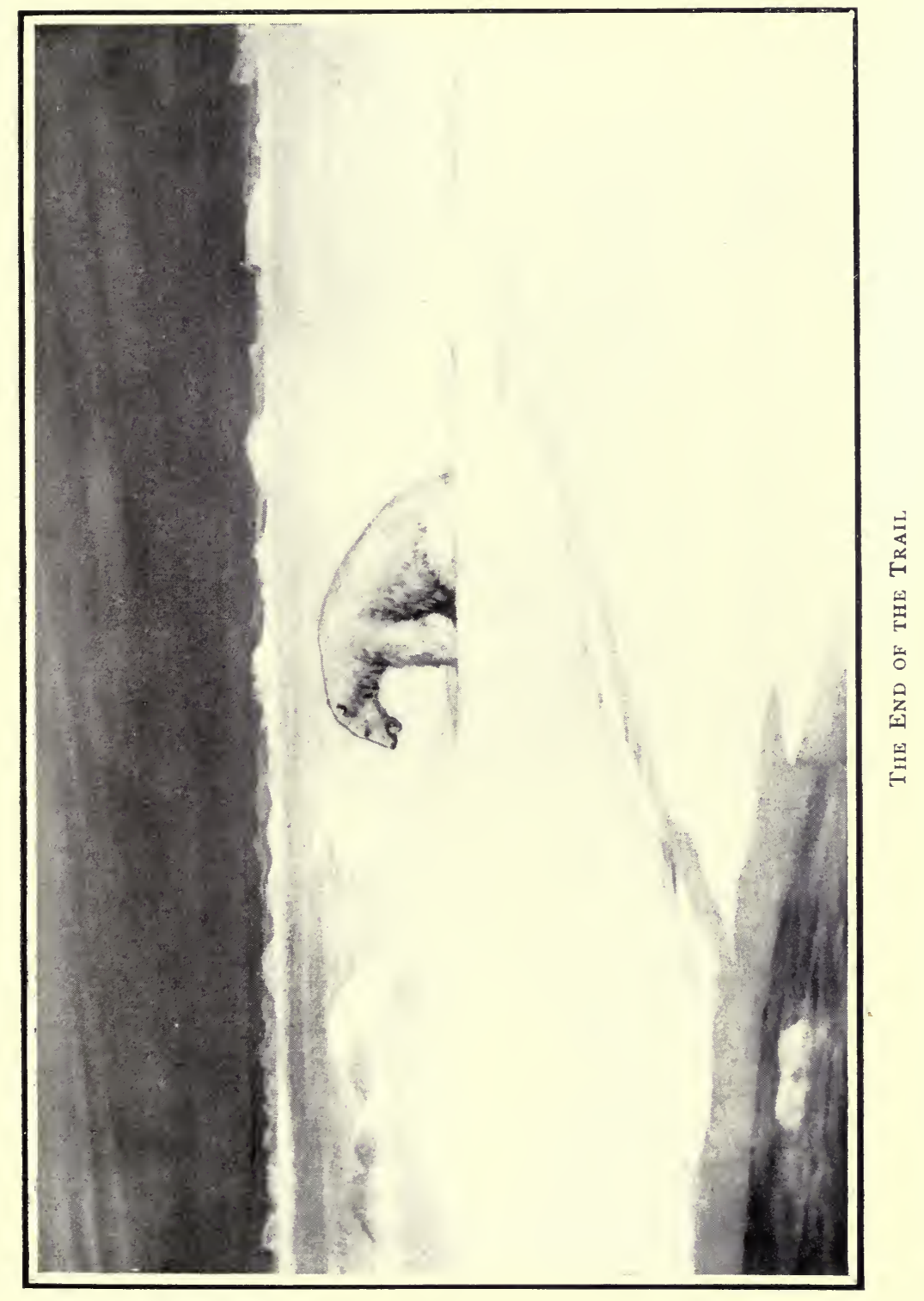



"Now you have shown me your vill ees stronger den de beasts'-now I vill leave you," and she did. And through his life his second wife was his right hand.

What a huge industry has sprung from that new harpoon first planned by Mr Welsh in Dundee, but developed in Tönsberg by Svend Foyn, working with Henriksen the engineer, that wonderful patriarch of Tönsberg. Gruff old Svend Foyn died in 1895, a millionaire; but he preserved great simplicity of life and dined off one tin plate, and despised luxuries; and only one ailment did he ever suffer from, that was toothache; so if anyone had toothache they got his sympathy, no other complaint got any. Only one man in Norway could get to windward of him, and that was Yensen, his steward. Once Foyn came on board at night and Yensen was lying on the cabin floor very drunk, but with just enough sense left to clap his hand to his cheek, and when Foyn roared out: "Halloo, what the hell's the matter with you?" he groaned: "Toothache, Captain, terrible toothache." "Ho, ho," said Foyn, "I'll soon put that right," and he went to his cabin and poured out a sou'-wester of whisky, which he ordered Yensen to swallow neat, of course; he did so, and made a face, and had some difficulty in getting forward. Foyn was as pleased as could be next morning, when he visited Yensen and found he had only a headache. The steward was very diplomatic and tactful. Once, with his Captain, he went up a high hill somewhere about the Nord Cap to look out for whales in the offing and there came such a clap of wind that it blew the great Foyn down and hurt his person and his dignity. But on looking round he found Yensen slowly getting to his feet, muttering: "That was a terrible blast, Captain." Yensen had really not felt it at all, so he saved Foyn's feelings.

His new industry has been the making of Southern Norway and half of Tönsberg. But the Tönsberg people remember him with mixed feelings. They would not subscribe capital to their townsman's new venture; not only that, but they insisted on his doing all his whale factory work outside the town. "All right," he said, "if you won't take a share in the business I will give you the "smell," " and he built his 


\section{WHALING AND BEAR-HUNTING}

works to windward and made many hundreds per cent. profit for years, and the Tönsberg people only got the smell. Now, however, there are very few men in Southern Norway who do not have shares in one modern whaling company or another, and the island of Nottero, for example, in the south of Norway, is dotted with pretty homesteads, owned by successful whaling owners, captains and mates. There they call whaling an Industry. Here, even though we tell of eighty per cent. dividends running for years, it is called a Speculation.

But to come back to our whales. Whilst enjoying the sun through the mist and the intense stillness we heard a deep growl or groan, something like a bear or a cow, a deep note which seemed to come from the floe across the little bay I have mentioned. Peering into the sunlight track, on the

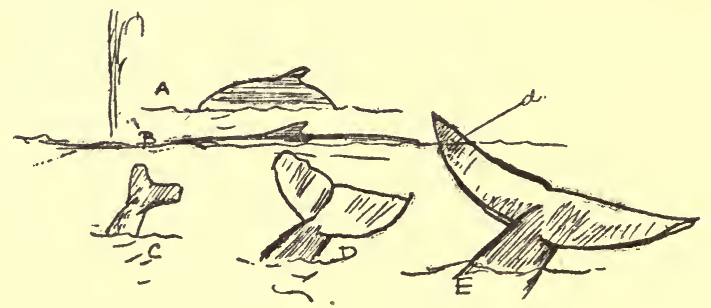

water we noticed forms moving and more groans came from these-Narwhals they are!-and away we go, get the gun uncovered and two 4775 shells in the breech of the big rifle, and just as we came to the place where they were, there they are no more, only an oily swirl on the faint ripples. So we lie on our oars and by-and-by they appear again down the iceedge-seven or eight. I practise laying the gun and harpoon on to them and fondly hope I may get within range. Then comes the chief of the clan, a glorious fellow; how I do desire to own the great horn which I' see for a moment. Next time he comes up.I feel sure I shall let go, and have the gun ready, feet spread out and the line all clear. But they are gone! off under the ice, and again we lie idly waiting. Then Archie whistles from the ship and signals that he has seen them out seawards and away we go, and as usual arrive at firing distance just as they "tail up " for their long dive. 


\section{WHALING AND BEAR-HUNTING}

Some whales "tail up" before a long dive; some more, some less; some finners only do this A dive after showing several times and blasting $\mathbf{B}$. But these narwhals show their dumpy feeble tail, $\mathrm{C}$, as also does the sperm $\mathrm{D}$, before

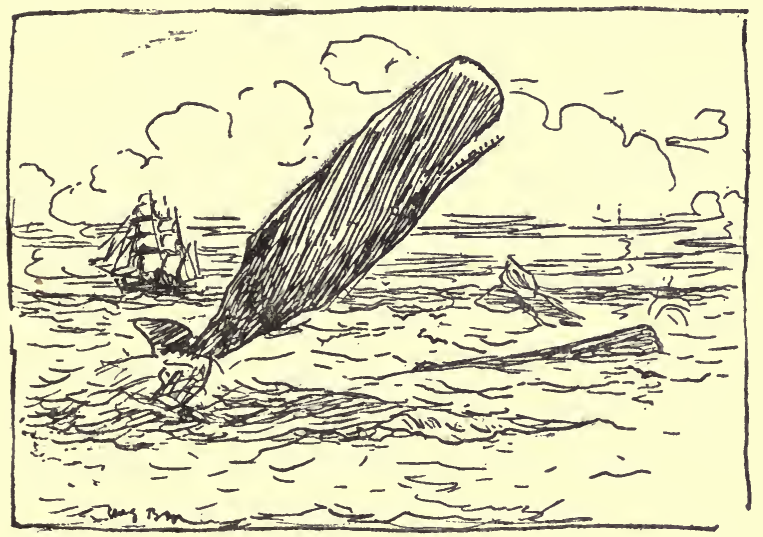

Sperm breaching

the long dive. The rorquals' tails are magnificent appendages, and it is often thrown clear of the sea when such a whale is "fast" or harpooned E. The sperm can make a

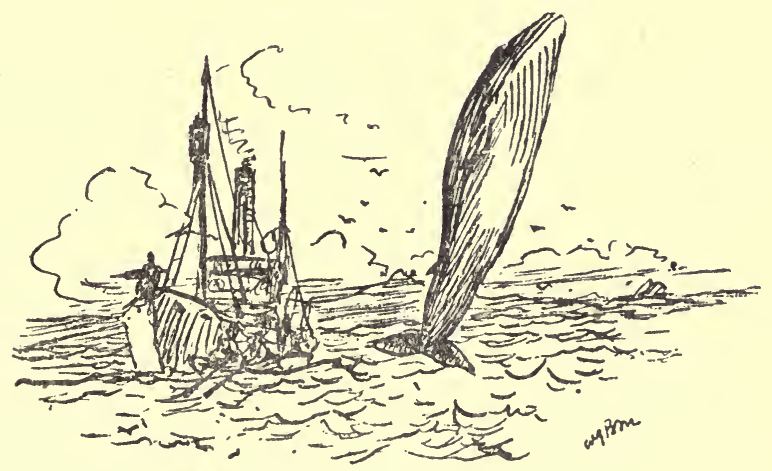

Small Finner leaping

big swipe with his tail ; it is apparently more elastic in the spine than the finner. To see a sperm breaching is a fine sight; he runs fast along the surface, every second leaping clear out, or at least going, as it were, on his tail, and thumps 
down with a crash of spray. Though I have seen thousands of Finners I have only seldom seen them leaping clear of the water, but here is a jotting of one that rose several times within thirty yards of us-close enough! leap after leap, its tail ten feet clear of the sea, head first, straight up into the air and down again head first; what stupendous strength and what delicate colour, its underside white as kid, ribbed like corduroy, its back grey, glittering in the sun (see page 235).

We left our sheltered ice bay this morning, 19th July, because the mist lifted and the sky hung in level lilac bands above the ice-floes, and we got a few hours' further steaming through the ice towards the coast. And I am rather sorry. For we had got to know the biggest ice features of that bay, and the fishing and shooting were worth quite a good renttwo bears, one narwhal and lots of hunting for other bears in two days. I would have stayed a week more there myself and so would Gisbert, as we are both very keen about the narwhals, but the others were not, and thought there wasn't much chance of getting within shot.

I must say the narwhals were provoking, rising trout in a chalk stream are not more wary, still there was always a chance. I'd have given a good deal to land one of these splendid ivory horns. Time after time we got almost within harpooning distance and the group of long spotted black and white backs would signal to each other and quietly disappear and sink. We stalked or rowed as quietly as possible to one lot, and I had half a chance and let drive but the harpoon struck water just a foot short of the nearest and biggest. What a flourish of tails and spray there was as they plunged and left great quiet swirls in the rippling water ; our boat and hearts bobbing but no whale fast to a straining line. You salmon-fishers don't know the saltness of the tears for a missed or lost whale.

Svendsen, who has only done bottle-nose harpooning, was put on for next chance and did exactly as I had done, only he got his hand cut through the butt of the harpoon-gun being a bit loose. Truth is, our gear, guns and line on the 
Fonix are rotten. He told me a curious thing that happened with him a year or two ago; whilst bottle-nosing his mate had made miss after miss at whales with the harpoon, and coming alongside he said: " $B y G$-, if I can't hit a whale I'll hit a gull " (fulmar petrels were, as usual, round the vessel), so he blew at one and the harpoon cut it in two! But a bottle-nose is an easier mark, to my mind, than the narwhal. Narwhals are apt to show so little above water-only about four to ten inches, and that only for a second as a rule.

Almost at every watch we heard their groanings and went after them. Sometimes we thought we heard the sound coming from under the water. I am sure we did.

Our biggest disappointment came at night-two in the morning rather. A bear was spotted-a bear on the far side of our loch, and Gisbert went off with some men in the whaleboat and we watched in our night clothes (much the same as day clothes in the Arctic) and saw the captain do a record sprint over the floe to turn the bear towards the gun, but the bear that at first seemed inclined to come and pass the time of day changed his mind and went ambling away, giving us a stern view till only its black nose and mouth were visible, as it looked round occasionally, and then it vanished in the lilac distance amongst the snow hummocks, and the writer turned in, thinking the play was over. But this morning, I am told, the real disappointment came. They gave up the bear, for a large black-and-white narwhal, with a magnificent horn, appeared round the ice point and they rowed round for it. It was lying leisurely on the surface, only going below occasionally. Gisbert was to take the harpoon. They made a splendid approach, breathlessly still, oars not making a sound, and got within five yards! And the whale rose high out of the water and Gisbert pulled the trigger, and the gun missed fire. The cap that explodes the powder had been withdrawn for safety, when they began the bear-chase, and not replaced! You can imagine the disappointment. I can assure the reader that such an approach, the approach and hunting of any whale, in fact, is far more exciting than one's first stag or bear. There is more risk than in bearhunting. But a danger of the narwhal is that if you make 


\section{WHALING AND BEAR-HUNTING}

fast to a young one the rest of the family, parents and relatives, are down on you and you have a chance of getting the great ivory spear through your boat. There is all the possibility of lines and legs getting mixed, boat upset, or dragged under floes, and lots more, if you care to tot them up. Curiously, there have been far more lives lost at bottlenose whaling than at that of the larger kinds (the bottle-nose and narwhal are about the same size). A bottle-nose is not larger than the narwhal, but it goes off with such a dash that I have known several men to have been carried overboard-Captain Larsen for one. He told me he went over with coil round his leg, and another man in front; he got loose but the other man never came up again.

The great Svend Foyn was once taken overboard-that was with a five-inch rope, after a finner whale, which is seldom or never known to check its first rush. This one did, slacked the line and Svend Foyn came to the surface and struck out and clambered on board, where the mate stood white with horror, and all the welcome he could muster was : "I-I-I am afraid you are wet, Captain!" and Foyn laughed himself dry. . . .

Then Fortune gave a belated smile on our adventurers. The foolish bear left the immense floe, on which it was perfectly safe, and took a swim to a small one lying on the far side. Our boat having gone round after this narwhal, was therefore able to spot something moving across the calm water, and when the object got to the floe and crawled out on to the ice, great was their rejoicing to find their bear again. So they pursued it again and killed it with one head shot, one in the neck, and three in the body. It was a small bear, a female about three metres, thirty centimetres-that is, seven feet six inches-and had bad teeth and looked old! My last, about the same length, had splendid teeth and looked young. This accepted measurement, which we take from nose to tail, does not give a true impression of the size of a bear, for this bear standing up would be about nine feet in height. I do not see why we should not measure a bear standing up as we measure man, from top of his head to his heel. We never think of giving a man's height in feet 


\section{WHALING AND BEAR-HUNTING 239}

and inches from top of head to the seat of his trousers. And, besides, what is the end of a bear's tail? Is it the flesh and bone or longest hair? I've seen a hair about five inches long on a bear's tail, and including the water dripping from that you would have thought, by the measurements, it beat the record. 


\section{CHAPTER XXIX}

B EFORE we left our last misty anchorage we partook of a meal of both bear and narwhal. The narwhal's flesh is blacker than an old mushroom, and as food it is only passable. Young bear is our best food, but there is a lot of trouble about preparing it, for we remove all the fat, which has not a good taste.

This morning one of these little grey seals or floe rats looked at us from astern, and as I plan a motoring coat I felt called upon to deprive it of its pelt, painlessly, after administering a tabloid-lead in nickel. I do not think there is any sport in shooting seals without a pucca stalk, still, the skins of these little grey fellows (Vitulina, or are they a new species ?) are too good to leave. I think six will be enough for a coat. I have got three now.

The flippers of the seals here are highly developed, with distinct claws. In the Antarctic the flippers are less distinctly articulated. The finger-bones are more bound together by ligament, and the claws or nails are scarcely noticeable.

All day we travelled north and as westerly as possible, trying to get within sight of Greenland, and for once the sun came out and we felt as if we could paint on deck, and did so for a little - dead smooth sea, with fine icicles forming and very level fields of ice, with few hummocks, extending to the pigeon-grey ribbed sky on horizon-rather monotonous. The guitar was going somewhere on board and most of us cooling our heels in the silence. Only the captive bears seem busy-grate, grate, grating at their wooden walls; one got nearly out last night, when we were off after the narwhal. We saw excited figures jumping about on our foredeck, and when we came alongside there was fierce growling, poor old Port bear being prodded in the back to draw its attention, whilst three seamen struggled to nail on new wood in front of its nose-end of the cage. 
But to come back to this day that begins so quietly, we are now all agog, we had a splendid bear-hunt and spotted a female with cub, a very small thing, and it was fascinating watching all their movements and signs to each other. We tried to jam the ship to the floe-edge, but for hundreds of yards it was guarded by floating pan ice-that is, ice in cakes of a few yards diameter and not deep, only, say, a foot. A big whaler could have jammed through comfortably, but we are not strong enough and got stuck and retired as gracefully as possible and went a long round of miles and miles to where we could land on the true floe, practising lasso en route in case we may have another opportunity of throwing a rope over a live wild bear.

Later we spotted the bear and child, and Archie and party went off after it, and from board ship we watched their slow procedure and the bears' rapid disappearance. I thought then that the fun was over, and retired to draw-but they had the best stalk they have had. They struck the spoor of a bigger single bear, followed it by directions from masthead, and came within a short distance, when the sleeping hero awoke, and promptly stalked them, then Archie fired at forty yards. He says: "Give me pheasant-shooting and a covert side, and nothing on four legs bigger than a spaniel." It is rather an awesome thing seeing a fellow in white robes and formidable teeth, that when on his bare feet stands well over ten feet high. A cordite rifle is then a very comfortable thing to hold in your hand. The first bullet in the chest knocked the bear over and two more shots killed it. It took about five hours there and back to finish the bloody business. And even on their tramp home we on board were kept in interest, for Don José Herrero, with the captain, went out for a fourth bear-relationship to others not known-Svendsen tried to draw the bear after him, whilst Don José hid behind a hummock. A bear will always attack a single man, sometimes two, seldom a number, and the plan worked effectively up to a point. It was lovely to watch Svendsen's simulated frightened flight and the bear following, stalking him behind every hummock, keeping cover, and then scuttling across the open to make sure of its victim. But somehow or other 
the bear did not just come far enough and our second lot of hunters came back with nothing in the bag. Later, we noticed the same bear working along the horizon. I expect it will strike the track of the homeward drawn bear's skin. I hope he will evince sufficient interest in his deceased relative

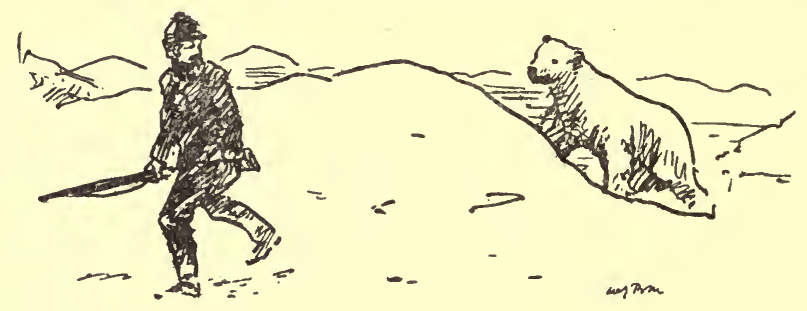

either to follow the trail of the skin to the ship or to the carcass; it was far too great a distance to bring in all the flesh. An eight-foot bear, nose to tail, ten feet four inches nose to heel, is a frightful weight, about nine hundred and eighty pounds.

It is still the Spaniards' watch and we steam away back to where we saw the bears first - if we cannot find whales we must take bears-En falta de pan, buenas son tortas (If you cannot get bread, cakes are good enough), and if you cannot get either bears or whales you must either draw, write, smoke, or go to bed. I would go to bed, but still have a lingering interest in my fellows' proceedings with the above ursida.

After the somewhat exciting afternoon and evening after bear, the night felt very quiet. Mist fell and stilled the least ripple. Archie came to my cabin-two can sit in it with a squeeze-and celebrated the occasion with a pipe and a glass of aqua vite, and he retold his adventures. I ought to have been with him, I believe, as comrade, to draw a bead on the ferocious opponent if necessary, and afterwards put it all down in paint, but Gisbert is most unerring in his aim, and being a little lame, I might have kept them back. At eighty yards, a big bear, Hamilton says, is very imposing, and when it stalks you to within thirty-five yards and you give it your best in a vital spot and it is not killed, you are 
inclined to wish yourself at home. You think of what will happen if your foot sticks in the deep snow or if you miss with your next, or only wound it. The size and shape of these wild floe-bred bears is far greater than any one may see in captivity. I suppose the age of the males, their food, and free life account for their enormous chest measurements and huge bowed forelegs.

It is certainly best to attack a bear in couples, on account of above-mentioned possibilities-lives have been lost by not doing so.

As we turned in, the mist rose a little and left a streak of palest primrose between it and the horizon, the shape of a great searchlight, but how delicate was the warm violet of the mist and the darker tint on the smooth water. In other ten minutes the light increased, then the sky was faintest yellow, except a low arch of cold bluish tint above the floe to which we were anchored; on the floe were three small icebergs.

Where we are to-night there is little life, only a few petrels chuckling quietly at our stern, where there is always some blubber hanging over for their benefit.

'There is not a ripple on the sea, not the slightest perceptible motion. I think the stillness and silence of the Arctic is a thing seldom noticed; the hundreds of miles of drifting floes which surround us break all swell. Everyone sleeps to-night after the exertions of yesterday. If there is a watch on deck I do not hear him; in my cabin the only sound is the snoring of our starboard bear. His berth is close to mine; when he does not snore he growls, a deep vibrating organ note, which is a little fearsome, and when he stops the deep note there is an ominous scrape, scraping in the stillness, that shows his set purpose to get out, and-what? I wish he was overboard or in our Zoo, or behind iron bars or something stronger than fir-wood battens, which he tears into moss in no time! A rat tearing wood is vexatious in the silence of the night, but to hear the patient and effective work going on beside one when you know there is possibly no one on the look-out, makes one anxious, so I keep my pistol handy at meal-times and between them. 
An uneventful Sunday. After the manner of our great examples of Reformation times, we held mild sports. Fencing, two entries, F. J. de Gisbert and the writer, we may not say who took the prize. Lassoing, five entries, De Gisbert and three Spanish, first Don José Herrero. Don José Herrero now surpasses our Professor Grisbert, and the writer comes only a little behind, but still a halo is seen over him for having lassoed a live bear ! Shooting at floating bottles, range inside thirty yards, Entries, the writer with Browning revolver, Spaniards mannlicher rifles, easy win for pistol, showing age and practice make up for telescopic sights. Pipe-playing, march, strathspey and reel, one entry, a walk over. Guitar accompaniment, three entries, De Gisbert easily first, steward and writer draw. Painting water-colour evening effect, one entry-judge the writer-subject, a pale yellow sky, lilac strip clouds above floe, floe high in tone, faintest pink with pale blue in crevices; prize not awarded.

In evening we tied up to a gap in floe-edge, hoping for narwhals, because they seem to keep close to edge of the floe. And sure enough they came when we were at evening meal, a great black-and-white-spotted bull leading, with a visible gleam under the still, dark water of his white ivory horn; after him, more drab-coloured whales, presumably Madame and bébés. We waited out in our boat, the writer with harpoon, and pursued two lots. One of them was a splendid bull, but both lots vanished a fraction of a second before I got a good chance at them, so we saved powder.

During the night we got to some extent embayed. We had floes all round, and raced round like a bird in a trap, but found a way out of the lake about four A.M.

As we plodded round in the early morning, it rained! straight down heavy rain and warm at that, with the thermometer two degrees above freezing-most unexpected and unsuitable Arctic weather-might as well have rain at Assouan! When the rain ceased thin mist still hung over the day and it was very quiet indeed.

Our Starboard bear seemed to feel the quiet and monotony and made a very good attempt to get out to-night. He did not seem very overpowering on the floe, but now, when he got 
his head and one great forefoot out and the timber was flying and six men struggling to nail him up, he gave one a sense of great strength. He is now inside the remnants of timber baulks of about three cages. As he chews one batten up more timber is nailed on over the first stumps. Some of us thought the bridge gave a good point of view : the struggling figure, and the steam of its breath as the cage was turned over, and Gisbert's cigarette smoke as he pulled and hauled and directed the various manœuvres, made a fairly dramatic picture. I thought my services might be called on at any minute with my Browning, but six men, active of mind and body, and various ingenious appliances of tackles and hatchets and big nails, at last made Bruin secure, and the stillness of the misty day come over us again.

Later, a great narwhal raised his back and tail right astern, groaned and went under with hardly a ripple, and we saw his white length come towards us under the glassy surface and disappear under the ship. So the whale-boat was lowered and a crew went out and lay a hundred yards off. My fishing instinct told he was the only one about, so I stayed on board and painted an ice effect. The whaleboat and men lay perfectly reflected, and looked almost too still and colourless through the thin mist to be real, looking more like a faded print of people waiting for perch than whalers waiting with stern intent to do or die. Bow lay on his back smoking, the smoke rising straight up, the others chatted in subdued voices.

On board, Pedersen the steward started his guitar and mouth-organ, and altogether, with the tum-tum, common waltz music, and the outer stillness it did not feel a bit as it ought to do in the Arctic regions,

\footnotetext{
؛ Where there's frost and there's snow And the stormy winds do blow, And the daylight's never done, Brave Boys,".
}

as the old song goes.

I have mentioned our many-sided steward. Photography seems to be another of his accomplishments-hobbies, I 
should say. Light or no light, he fires his camera. We could not help smiling the other day when he went for the first time on to the floe with a party to photograph a bear-hunt. Hardly had he gone five yards when one leg went deep into a hole in the floe and his shoe came off. He emptied the water, and then the other came off, so he hastily fixed his tripod, fired a shot at the ship and came on board again, and took to the guitar and his proper offices. To-night a sudden idea seized him and he left his cosy corner by our galley fire and Johanna, our "she-cook," and came with guitar and that instrument called the mouth-organ, and arranged our bears' heads and skins on the main-hatch, and sat himself down on a block of wood between them and got one of the men to fire his camera at him. But first he produced a pocket-mirror, when I called his attention to a hair being astray, and having arranged that, he pulled his white jacket into position, fixed up the guitar and mouth-organ and struck a fine pose. I might have fired a plate at him, but there was not nearly enough light. The head of Hamilton's enormous bear, as if resentful of this last indignity of having to pose in such a picture, broke the barrel it rested on as if in protest-even the head and neck is a big lift for one man.

Another picture composed itself a little later. We watered ship from one of these shallow blue pools on the floe, two men at the pool filling tin pails with a large tin bailer. To encourage them our jolly, burly vivandière went out to them with her cheery laugh, carrying a glass and bottle of aqua vite. There was colour ! and if not elegance, a beauty of fitness, which is saying a good deal for the lady ; the ample, strong form, in pale blue and white pinafore kind of dress, tripped over the floe, and the deep blue of the sailors' clothes and her red cheeks, and the golden yellow of the aquavit, the grey of the zinc pails, and the blue and white of the snow, suddenly struck one as the first decided effect of strong colour contrast which we have seen for days.

Nothing very exciting to-day, mist and snow on deck till evening, when it cleared, and became very calm. We were 
all at aften-mad when word came a bear was sighted, so our Spanish friends armed themselves and went forward to the bows, and the vessel slowly approached the floe on which the bear had been seen, and to our astonishment the bear approached the ship steadily, and lightly climbed a round snow-block and steadily gazed at us, a pale primrose patch in a great whiteness, with interesting dark eyes and muzzle. I have tried to recall the effect, but the highness of the scheme of colour makes it difficult to paint, and probably impossible to reproduce by any process of colour-printing.

Our friends calmly held their fire till within twenty-five yards when Don José began with his telescope-sighted mannlicher and hit the bear at his first shot! unfortunately rather near its tail. The bear, enraged, tore at itself. Then a sharp fusillade bégan from both rifles and by-and-by the bear succumbed. It had been hit not less than five times. It was only a small bear, but, as Don Luis senior remarked : "It was forte bien mieux de tirer from the ship than to go march, march, toujours sur la neige." This is the way we speak on board, with a little Spanish thrown in. 


\section{CHAPTER XXX}

$\mathrm{B}$ RIGHT sun for once and away we have been steaming since early morning, south and east, hoping to get clear of the great floes that bar our way to the west. I long for mountains, the flat plains of ice-floe and snow grow very wearisome. Now, near land, these land-floes are like endless plaster ceiling that has dropped more or less in fragments. In the Antarctic the floes look as if a Greek temple had come to bits and lay floating on the sea. There is a considerable difference, therefore, in appearance; at least I speak for the southern ice which I have met south-east of Graham's Land. There are no seals, therefore we hardly expect bears, and there is never a sign of the blow of a whale. Only one narwhal this morning, we almost ran into it. I wish it had driven its spear into us, it seems the only hope of getting a good one.

Floes extend in a line for miles north and south; we think it will be best now to wait for them to open, rather than to wander away south in hopes of getting an opening round them. Shannon Island, on the north-east of Greenland, is our aim.

... The floes are flatter, with fewer tombstones protruding from the level white; it gets monotonous. Mist comes at night. Hamilton and Gisbert play chess, Don José and the writer teach each other English and Spanish. Don Luis plays patience and Don José Herrero does nothing, with quiet dignity. This morning, after an hour at Spanish, I turned out first of our party for breakfast and found our starboard bear also on the point of coming out. It had its head and feet out and was only stopped by a single rope, a mere accident, but it puzzled the bear-rope was new to it. The she-cook and writer were the only people on deck. I tried to look not afraid and she certainly looked perfectly cool, and kept on wiping a dish, but went into the galley. I 
secured my revolver and told the man on the bridge. I tock the wheel, whilst he dashed below and called for help, and there ensued a wild struggle; Bruin had lost a moment at the last trifle, the silly rope that was slightly elastic giving way to his pulling. Several of the crew turned up and got some thin wood battens, but one after another, as they were hastily banged across the front, he tore them to bits. And he has learned that shoving is also effective, and six men this morning went back at first, to a shove of his two great paws, till they got leverage. "With a long enough lever you can move the world "- that is where our men came in. Now he has about eight inches of timber in front of his nose. I will give him two days, not more, to get through that. Gisbert says he is sure to go overboard at once if he comes out. I

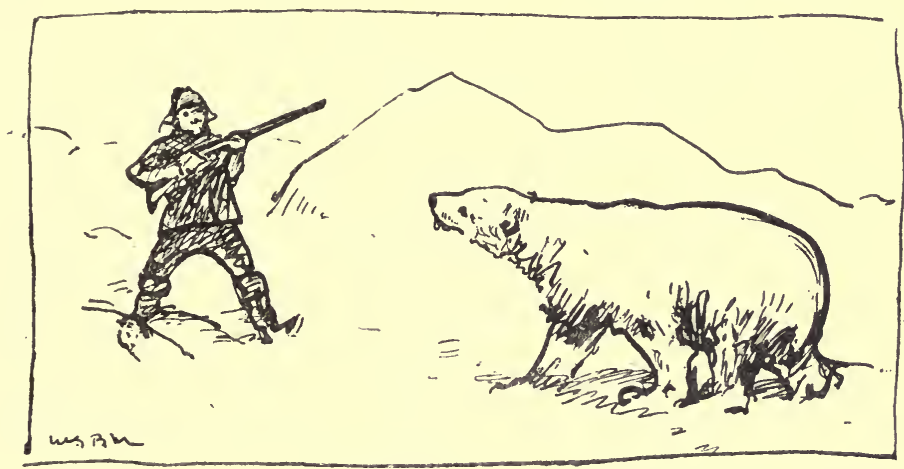

think it is as well to have my pistol beside me at breakfast; we must at least have a chance of some shooting if it takes charge of the ship and does not go overboard as predicted.

Gisbert tells at breakfast this touching little tale, possibly a chestnut, above illustrated. "Once upon a time a hunter met a bear and said : 'Here comes my new fur coat,' and the bear said : 'Here comes my breakfast,' and both were right! " With such frivolity he soothes our nerves. But the deep, vibrating note of Starboard and the sound of industrious scraping keep one on edge for the rasping tearing that comes when he really sets to work to get out. Some great chains have now been found in the bottom of our little hold, and he is now really being treated as a wild animal; the 
chains are being fastened all round the woodwork, so I will allow him other two days to get free. All our wocden battens are done or nearly done, therefore this resort to iron.

We-that is, De Gisbert and I-made a small discovery this morning in rope-throwing-we practise it at odd times, with the prospect in view of tackling other bears alive, which is perhaps even higher sport than shooting or photographing them. For some time we have almost all been able to cast
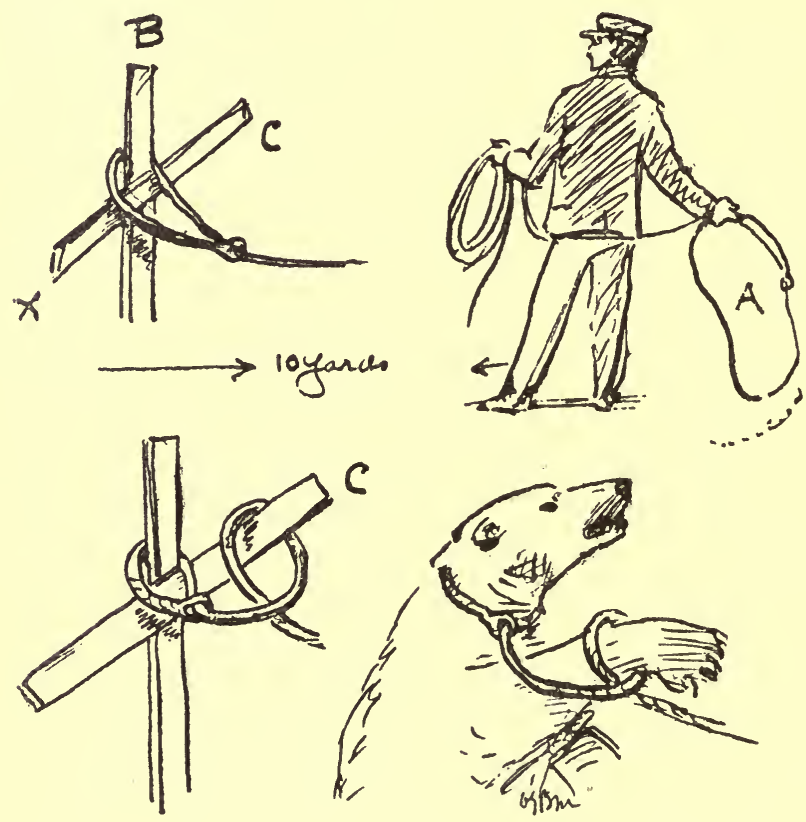

the ordinary running loop at short range, but are erratic with the half-hitch cast, such as you use after casting a loop over a bear's head to secure its forefoot.

I do not write these details for bear-hunters, but the game is excellent sport per se on deck, say, on a P. \& O. liner outward bound in August; it would be splendid on any deck, better than deck quoits. It would be excellent for a garden-party or sports for Boy Scouts. 
You beg or borrow, from the bos'n or laundry-maid, five fathoms of rope- - log line is the best. Splice a metal eye to the end to make a loop or lasso. Then you fix up a spar, with a cross-piece, and stand as in this sketch, with the looplarger than A, or to taste-and cast over B, with right hand, and haul taut with left hand. The next thing is to cast a half-hitch over C. You imagine B is a bear's head and you wish to throw a half-hitch over (C) a fore paw, so as to haul the paw up to the neck and throw the bear. Then you can try left-hand or right-hand casting over $\mathbf{X}$, which is not so easy!

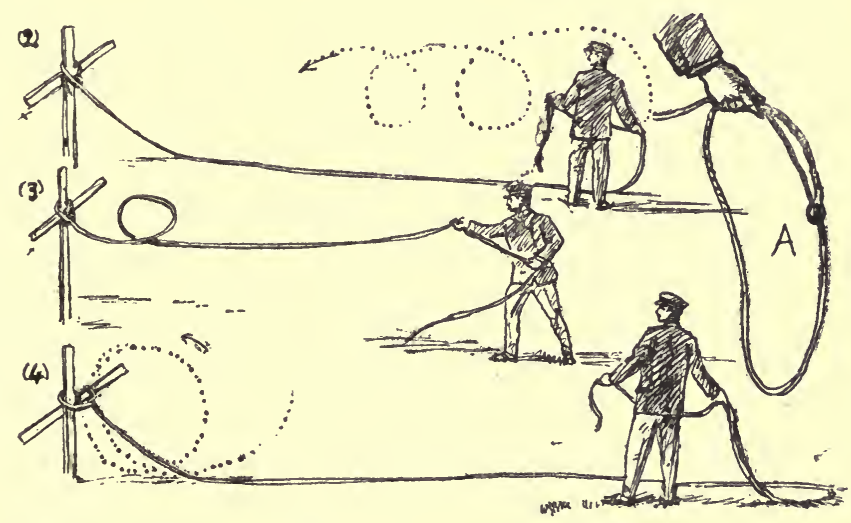

To cast the first lasso loop (note position of hand and eye in loop A) you swing the loop round the head and let fly and let the coils of line in left hand go free. This is a little difficult at first; casting on the half-hitch is much easier if you lay the line properly, as in Fig. (4). If you lay it as we did at first, as in Figs. (1) and (2), the loop falls short as in middle Fig. The idea is to have plenty line to your right, so as to make a big flowing hitch, as shown in lower Fig. (4).

Gisbert and I worked out this discovery in the morning till we could put on hitches every time, and in the afternoon we challenged the "Professor," as we call young Don Josébecause of his skill in throwing the loop-and his cousin, Don Luis Velasquez, for a bottle of champagne, and holding our hand, we easily beat them and felt veryslightly ashamed of ourselves for taking advantage of our small discovery of a knack. 
This morning in sunny mist appeared a dot, far away over the snow, and we put glasses on it and made out a seal. As our young men thoughtfully hung back from a stalk, it was left for De Gisbert and the writer to make the effort. Finally the writer started over very rough going, with very little chance of getting within shot, still, just to show an example, we felt one of us must try.

So we climbed over the bow and got on to the floe-edge and away from ship. It was very charming on the floe amongst these ice tombstones and ledges fringed with huge icicles that, in a wide view, are simply monotonous white, but which all become very sweet and beautiful when you are close to them and can examine the details at leisure. The only way to see nature thoroughly is to have it rubbed into you. Who can see a rainstorm with an umbrella up? When you have one leg in a hole in the floe and the other on the floe, and hands, rifle and staff going, you do not know how deep, there is plenty of time for the dripping icicles over the blue ledge in front of you to impress themselves on your memory; and for a time at least, the seal you are stalking, or even the bear that may be stalking you, or when you think of the beauty in front, the cold in your boots, become of little importance.

Then you toil on, dripping from nose and eyebrows just like the icicles, for on this blessed day of days through these mist wreaths there is hot sun and the ice-floe glitters gloriously. Everyone said that the seal could not be approached. But by dint of much consideration and a crawl here and there, I managed to get within a hundred and fifty or a hundred and sixty yards. Then I thought, "Just to show what could be done by old age and experience," I'd try to get even closer-to a hundred yards-that lost the seal for me; for when I got behind the tiny knob of ice I aimed at the seal had got into its hole in the floe. For the last fifty yards I was following the two or three days' old track of a bear ; I wonder if he and I had both stalked the same seal with the same result.

A day's stalk, or rather a few hours' stalk, after a seal suits my taste, and Hamilton agrees. He says, apropos of a big 
serious old bear-stalk: "Give me a pheasant cover, with nothing on four legs bigger than a spaniel." You don't then have that sensation of cold water: you are quite comfortable and can claw down your birds and chat with any fair one who has begged to see you do it.

From above, the careful reader may gather that we have at least in this Greenland sea seen the sun. It is nice! Now, as I write, about twelve o'clock midnight, it may be said to be shining; and in the rays, with double winter clothing, it is really quite warm. But in the shade there are many degrees of frost; that is why the icicles hang so beautifully to-day over the blue ledges on the shaded side of the raised edges on the floes.

It is a poor floe and feeble ice compared to that in the South. We passed a berg this afternoon, an Arctic berg, so we said: "How grand!" But in my mind I saw again the stupendous ice-cliffs of the South and their vast green caves, into which you could pack a dozen such Arctic iceberg chips.

The atmosphere and colouring here remind me of the east coast of Scotland in June, clear, crystalline, unenveloping, quite unlike the velvety feeling of our west, towards the Gulf Stream, say down the Wigtownshire coast, or the west of Spain.

I have often seen this scenery depicted in old whaling pictures, where the ships and whalers look quite large in proportion to the ice-forms. This is the difference between Arctic and Antarctic. In one, man and his vessels dominate the scene, in the other the great forms of nature make man and his works seem very small.

This afternoon with my pistol I shot an old female seal through the brain-this after a futile stalk of hours for a seal in the morning with long-range rifle and telescope sight.

'Though we can't find whales yet, the colour of the water is promising; it is full of plankton: if you draw a muslin net through it you collect in a few yards, in the tail of the bag, an almost transparent jelly-a minute quantity of which, examined under the microscope, reveals marvellous beauty, millions of minute crustaceans and diatoms that fill you with wonder at the life in the seas, which infinitely 
surpasses in multiplicity the life of the land or the air. These probably form the food of the shrimps and little cuttle-fish, and the narwhals eat the cuttle-fish.

The narwhal we caught the other day was full of small cuttle-fish, only about a few inches across the spread of their tentacles, and it also held red prawns or shrimps. But the cachalot or sperm whale of the warm seas kills very large cuttle-fish. We dare not say up to what size. I myself have only seen the sperm, after it has been harpooned, eject small cuttle-fish, but large circular marks in their backs, something like Burmese writing magnified, look as if they had been caused by the sucker on the tentacles of enormous cuttle-fish, and wandering grooves over their sides suggest that the parrot-like beak of the cuttle-fish has made its mark. I have seen one of these at least thirty-five feet in length. The contents of the stomach of many of the largest whales in the world, Balænoptera Sibaldi (Blue) and Balænoptera Musculus (Finner), which are killed nowadays, consist almost entirely of small shrimps, about one quarter of the size of the common shrimp. On the landing and flensing stage of Alexandra Company in Shetland, after several finner whales have been cut up, I have seen piles of this shrimp food lying on the slip, amounting to several tons in weight, with only, on rare occasions, a few minute fish amongst it all.

The food of the whale that used to be more common up here, the Right whale, Balæna Mysticetus, is ábout the size of barleycorns and looks rather like sago with a brownish tint. The whale takes a mouthful of these, plus water, and squeezes the water through the blades of whalebone round the edge of its mouth, each of which has a fringe of hairs on the inside. These hairs, interwoven, make a surface to the palate like that of a cocoanut mat, which makes a perfect strainer. Then the whale swallows the mass of minute crustaceans that is left on its tongue and palate. The tongue is an immense floppy plum-coloured thing like a deflated balloon. I would give much to know exactly how its nerves and muscles act so as to work down the minute food from its palate into the throat. Smaller Finner whales we know 
of, which feed on herring, round the Shetlands and British coast, locally called Herring Hog, or Springer, run to thirty feet or so. They are not hunted as yet by the modern whaler as they are rather too small to be worth towing to the station, but no doubt their day will come when our industries need them, and the large whales become more shy and hard to capture.
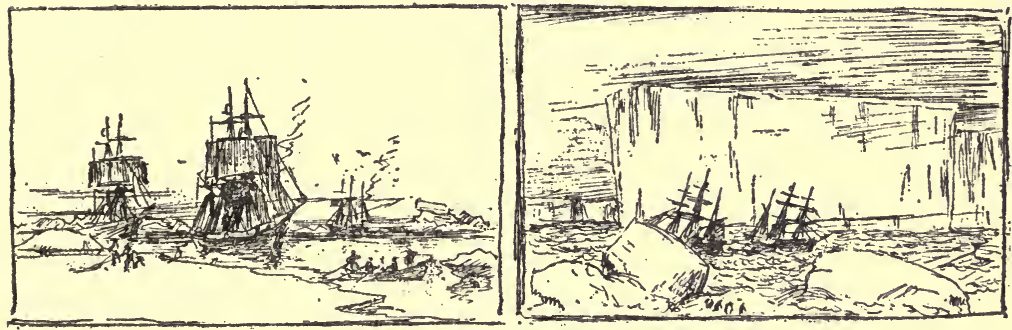

Arctic and Antarctic Proportions 


\section{CHAP'TER XXXI}

HIS chapter will show that it is foolish to sit up late, and that it does not do to shoot polar

I bears in pyjamas. Last night Hamilton and I sat up fairly late playing vingt-et-un for matches. But the Dons and De Gisbert sat up still later, almost all night, brewing a concoction of seal-oil and things on the cabin stove for boots. Just as they succeeded, it upset all over the shoulder of Don José junior's coat. They were very merry, but they should have been in bed, as it was their morning watch at nine o'clock, and they went to bed not long before that hour. Spaniards are quite reckless of the night hours, a few days' stay in Madrid will convince anyone of this-the people walk about all night. The aforesaid brothers when they did turn in got into pyjamas-how people cling to custom. Gisbert, being more experienced, of course turned in all standing, as anyone of any polar experience always does. Now they are sorry for these late hours and for sleeping in pyjamas, for result. Soon after they had turned in, there appeared a very large she-bear and two cubs close to the floe-edge, which could have been shot from the bow. Just the chance they like, no horrid walking and stalking over snow. Gisbert was ready in a minute, but they lost the precious time getting out of the pyjamas into warm clothes, and the bear could not wait, and perforce they had to follow her over the snow and a fog came down.

They have lost it; and here we are, a whole ship's company, sleeping, or doing nothing but grousing and counting the hours, as we lie on dead-still water in dead-still fogwhich is waste of time and patience and is quite absurd, Q.E.D.

We are back to our last bear forest, "the woods are full of them," as Hamilton says ; back to bear-hunting because 
there are no whales and because our path west and south and north is barred with ice. Perhaps by the middle of August there may be a road open to the land. We have seen the mist on the hills, at any rate a wide stretch of many miles of whitish light thrown up to the sky, which tells us that the land is there and that we are not more than fifty or sixty miles distant from it.

We still hope to get the she-bear and the cubs; they are nice small cubs, not like the well-grown wicked fellows we have on board; we could almost make pets of these small fellows.

A man we know of got one a year or two ago. He was one of three Norwegians left on a certain island in these latitudes-we will not give its exact bearings-to collect skins during a winter. They got a hundred bearskins and ninety white fox of considerable value, and they are there still in barrels, and ought to be quite good yet. They lost their boat and were picked up and taken home. They had a baby bear, which they brought up on the bottle. It was a charming pet till about twelve months old and then he had to be destroyed or he would have killed them in play.

I am sorry to say here that at middag's-mad we, aft the mainmast, had not remembered this was Sunday till pancakes came on the table. As the second lot arrived the steward stepped in rather quietly and whispered: "A seal astern," so we jumped out with the pistol (by what some might call a lucky shot), hit it through the brain and it floated dead, and a white ivory gull hung over it. It was just the kind of skin, too, I wanted for the projected motoring coat. Then we realised it was Sunday, and to make up leeway we displayed bunting, the Royal Spanish Yachting Club and our Royal Eastern Yacht Club-the vice-commodore's-and the Red Lion of Scotland (the origin of which is buried in the mist of historical obscurity) at the fore, quite a gallant display for such short notice.

With the flags' first flutter the air went round to the north, and now, instead of being heavy and depressing, there is a bracing feeling, and the eye can see far and wide amongst the lanes of sea-water and the floes of hummocky ice. Harp 
seals dash across the surface of the loch we are in, as if they too enjoyed the change from damp, heavy air to the keen, sharp, exhilarating air from the north. There is no use firing at these harp seals in the water, for they always sink on being shot. Besides, some of us think a shot might disturb the she-bear and family. She went off to a floe about the size of Perthshire, and we follow round northerly, and perhaps to-morrow morning we may sight her again.

One of the prettiest and rarest things in the world is to see a mother bear with her cubs, the little yellow fellows with their black eyes and noses jumping and rolling over their mother, pulling her ears, and the old bear showing every sign of love for her offspring. Then to see the old bear stalking a seal and the little ones sitting away behind, jogging each other, making notes about their mother's cleverness. Their education takes two years. The smaller black bear of Newfoundland and America sends away its young after one year's teaching; there means of subsistence are more simply obtained, there is so much wild fruit and so many roots and other things for them to eat. But to stalk a seal up here on these flat ice-floes, even with a rifle, takes very considerable skill. I speak with feeling. For the bear to get within clinching distance must require even greater experience. The polar bear has usually two and sometimes three of a family, not oftener than once in two years. The mother is frequently seen with only one cub and the father is then supposed to have eaten the other. The male bear is said to take little or no interest in the education of its young. Why the young, two or three year old bear we first caught showed such interest in the old bear, Hamilton's first bear, I cannot quite understand, for though he kept half-a-mile to leeward he always seemed to have an eye lifting for the old bear's movements. I wonder if he was waiting for the old fellow to kill something, then to drop in on a neighbourly call about meal-time.

Alas, this journal is all bear as yet, and no whale to speak of; I have never been in such lifeless water anywhere in regard to cetacean life. And yet we should see various whales, the Balæna Mysticetus, called the Right whale, 
bowhead or Greenland, the fat, slow, but valuable whale of the old-fashioned whaling.

In the evening a bear was spotted. Gisbert and Don José and three men set out after it. With the glasses we saw the bear disappear in the distance and then the little black spots of straggling figures also disappeared. They returned several hours later in the best of spirits, though they had never seen the beast. They had fallen in with a curious experience. On the floe they found a greeny blue grotto-I remember we saw them standing on a high ridge, it must have been under this-into which they went, and were amused at the ghastly silvery appearance of their hands and faces. It was about fifteen yards long, and they could walk in upright, with a blue shallow pool in the middle, and overhead part of the snow and ice was thawed to about a thickness of a few inches and the blue light shining through this with icicles hanging thick, gave an effect that can be imagined. I think I would rather have seen that than have killed the bear. There were no bears in the grotto; but I know of a man, Captain Yule by name, of Dundee, who killed-well, I hardly like to say how many bears, in such a cave. Take a blue cave, whity yellow bears with their dark eyes and the sombre figure of the man, and rifle smoke, flame and blood, and you have a picture fit for the cover of The Wide World Magazine.

They had walked about ten kilometres over snow, rough going, and came back about one A.M., wet, with ice on beards and moustaches, but glowing and happy with the exercise. They had a hot grog, got off long boots and were very comfortable, when another bear was spotted, and away they went over the bow by the rope-ladder to the ice, chawing biscuits and chocolate as they went. Don José being a little tired his cousin took his place, and Gisbert went off merrily. Spaniards are very sporting so far as I know them; they work up to their collars, always keep up a cheery appearance, and-can't they sleep after exercise-it is now past midday and there is not a sign of any of them! There is a fresh breeze, but it is foggy, with sun overhead, so we cannot do much. 
To put in time I took a boat after a hooded-seal, which I spotted through a lift in the sunny haze about a mile off on a small floe. We excuse ourselves killing seals by thinking of the benefit we confer on our fellow-men in the South by adding to the general store of material used in the manufacture of margarine and olive oil; but besides this base commercial consideration we have our captive bears to consider, they must exist, to afford amusement and instruction some day in our Zoological Park in Edinburgh, London, or Madrid. As I approached, the seal finally shovelled himself off the snow into the sea and disappeared. Trusting to its showing some curiosity, we waited, and it came up about a hundred yards off, and showed part of its head, which I managed to hit, but it disappeared. So we waited about the place, and by-and-by it came up only about twenty yards away, when a shot from the pistol finished its pain. In my experience it is a very rare thing for a seal to reappear after being wounded or killed. I must disagree with Sir Ernest Shackleton in this matter. He said in a lecture to our Royal Geographical Society apropos of Antarctic seals: "As fast as we killed them, up they came again."

It is a strange life this up North, a little while ago mist and cold, and you longed to be home-wherever that might be-and now the sun is shining hot, and you might be in a yacht off Aberdeen in summer; it is the same crystalline atmosphere, with cold air, hot sun, but bracing-very nice indeed! But up here there is some risk!-only two hours ago we were in a tight place. No real old Arctic whaler would mention this; they all minimise dangers-for their own comfort; if they did not, they would end in staying on shore and going to the workhouse. But the writer, who is only an amateur whaler who " only plays hide-and-seek with the sea," as a nephew of mine puts it, may be allowed to say that there was grave danger, and putting aside whale and bear dangers, there was in this one of our first really nice, sunny evenings, a very serious prospect of our spending the last few months of our lives on a floe with a failing commissariat. We ran ourselves on to a green ice tongue that we thought had enough water over it to float us, and got fast. I was 
below, and though accustomed to the ordinary shock of ramming ice, I knew at once, by the long rise of our bows and the roll to port and starboard that we were in a fix. Perhaps a small diagram may help to explain - so here you see two floes meeting, bright sunshine, blue sky overhead, and rippling blue water where there are open pools in the ice-a scene of perfect summer peace. The two floes, each weighing millions of tons, are very wide; they are slowly moving towards each other; they nearly meet; and we mistakenly try to get between them before they close, and run our stem and half our keel on to A, the submerged ice-foot of the floe B. The floe $\mathrm{C}$ is coming towards us in the direction of B-well, to cut it short, if the floes $\mathrm{C}$ and $\mathrm{B}$ meet, with the Fonix between them, our party, thirty all told, have our little house

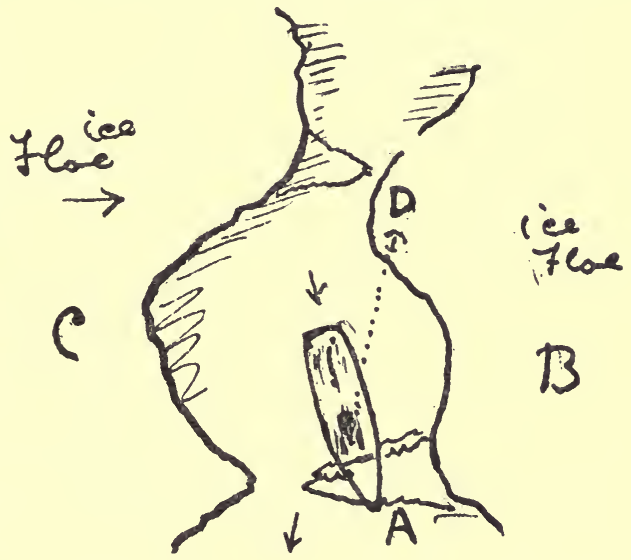

squeezed, and when the floe opens our home goes down and we get on to the floe till we are rescued by some relief expedition, or we flicker out. But for having lots to do I personally would have felt the necessity of a pipe or a dram-but as it was the writer and two men and a boat had their hands full, getting out an ice-anchor and wire-rope astern to $\mathrm{D}$ to kedge her off. The said hawser burst and the artist showed the seamen the bend for a wire-rope, in a hurry or at any time. Boy Scouts know it. Hamilton stood by at the wheel and Svendsen and men shifted the cargo aft to take the weight off the bow. An ice-tongue of floe $\mathrm{C}$ touched at $\mathrm{D}$ and gave us breathing-space and by-and-by we kedged her off astern, just in time to avoid a squeeze, and got through between the floes. One might write a chapter about our 
manœuvres, but now the guitar is going and the skipper has thanked the artist for handling that nasty rough, rusty wire hawser against time, and expressed somewhat flattering surprise at his knowing how to make a simple fisherman's bend in a hurry; and again we are in open, quiet waters and open ice, with a hundred yards between each floe, and everyone frightfully cheerful. For some of us at least knew, though our Spanish friends apparently did not, the grim possibilities. Also we are all the better of the efforts in a small boat and the work of shifting cargo, barrels of salt, etc. I guess and bet Svendsen will not take any more unnecessary chances of dodging through too narrow lanes between this time and the next.

By late aften-mad we have quieted down, and have a beautiful display of the bull ring. Chee Chee, our young Gordon setter (or collie; it's a little of both), does the bull, Don Luis Herrero de Velasquez does our espada, and other bull-ring functionaries all to perfection, with a foil for the espada and a sack for the Vueltu, this on our upper deck in the ten o'clock P.M. sun, everyone applauding and the steward's guitar joining in below. His music is very cheap music, in such a contrast to Gisbert's old airs, half Spanish, half African, that go away down to the depths. 


\section{CHAPTER XXXII}

$\mathrm{U}$

GH-ugh !" our starboard bear shouts to-day; not a roar now, it is a hopeless complaint. "Ugh! let me out-ugh! look at my coat, all stained and soiled. . . . Ugh ! let me out, I don't want to go to a zoo "then almost silence, only a steady chawing of timber and scrape, scrape, for hours on end.

The above labour ended in his getting his head and one paw out this morning early, and the skipper and Hamilton only being about-the rest of the crew were afloat in the boats-they had a lively time. The skipper anxiously shouted : "All hands on board!" and they came and all bore a hand, and there were timbers, nails, hatchets and hammers all about, and bears' roars, till it was subdued. Hamilton got his hand hurt. It is a wily fellow this starboard bear, waiting his opportunity till all were overboard hunting, and again I expected to have to use my pistol. Almost all hands were in the boats securing two bear cubs, about a third of the size of the bear referred to. We spotted them and their mother on a floe about five A.M., playing together, poor things, and they took to the water and we pursued. Dauntlessly we approached, Don José in the bow, rifle in hand. Without tremor he calmly held his fire till within a few yards; the first shot went extremely close, a second actually touched the bear, but the range gradually shortening allowed of greater accuracy and the third shot hit it in the neck and killed it.

A boat followed the two youngsters, and after a number of ineffective throws they were at last roped. From boardship we rather smiled at the ineffective attempt to lasso, but we gather that several casts were well thrown and over their necks, but each time the cunning little beggars threw the 263 


\section{WHALING AND BEAR-HUNTING}

noose off their heads with their paws so quickly that there was not time to haul taut.

Now there is a frightful row going on; the two cubs are roped alongside and the two seniors on board, all are shouting : "B-e-a-r, b-e-a-r, w-augh, w-augh, b-e-a-r." Holy smoke! It is as if half-a-dozen zoos were in chorus and were shouting for dinner; it is a frightfully tiresome, irritating sound, arranged so by Nature, I suppose. No mother bear could shut her ears to it, were she alive. The two cubs, each on a line, are swimming; they seem to prefer the water to the floeedge. A huge mushroom of ice, pale blue and of exquisite form, drifted alongside, and the young male cub got on to it and it slowly turned over-how he swore and gnashed at his rope; but what exquisite delicate colours, the bears, the ice, and the reflections make. They are brother and sister ; the brother is the stronger and makes, if possible, more row than his sister in their struggles for liberty. But he threatened his sister, thought it was all her fault. He was swimming behind her and made a pretence at biting her ; she did not argue, simply turned, and in a second put her four white teeth into his cheek and the yellow face flushed with blood and he said no more. So they go on complaining together or alternately to us and to all nature. Now the little woman goes on to the floe-edge blown, wheezing and puffing-how she tugs violently at the rope, a faint primrose heap of impotent anger and wretchedness spurning the white snow. "Bear" or "Be-waugh" in bear language must mean "Mother, why don't you come to help us ?" The sea is red with poor mother from our scuppers. Her skin is off her pathetic-looking red body, to decorate the boudoir of some lady of Spain.

To condescend to the base commercial aspect of our hunting, a living bear is undoubtedly of much greater value than a dead bear's skin, yet I believe our joy would emphatically be greater were our four live bears dead, for apart from the natural fear of our lives, should either of the larger couple get out, we have to endure their ghastly chorus at all hours.

Hamilton, being nearest, perhaps suffers more than some of 


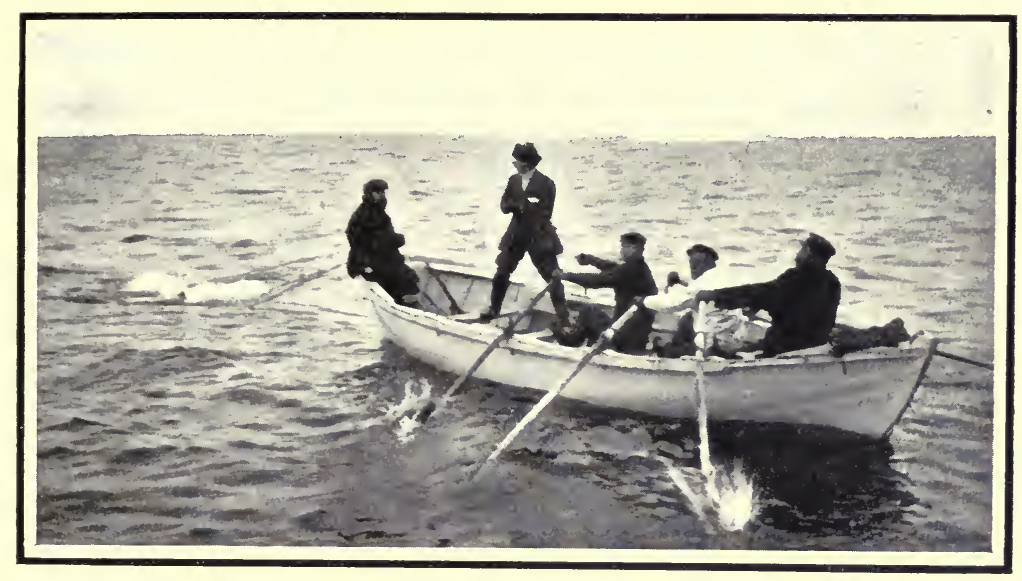

Towing Two Bear CuBs to The "Fonix"

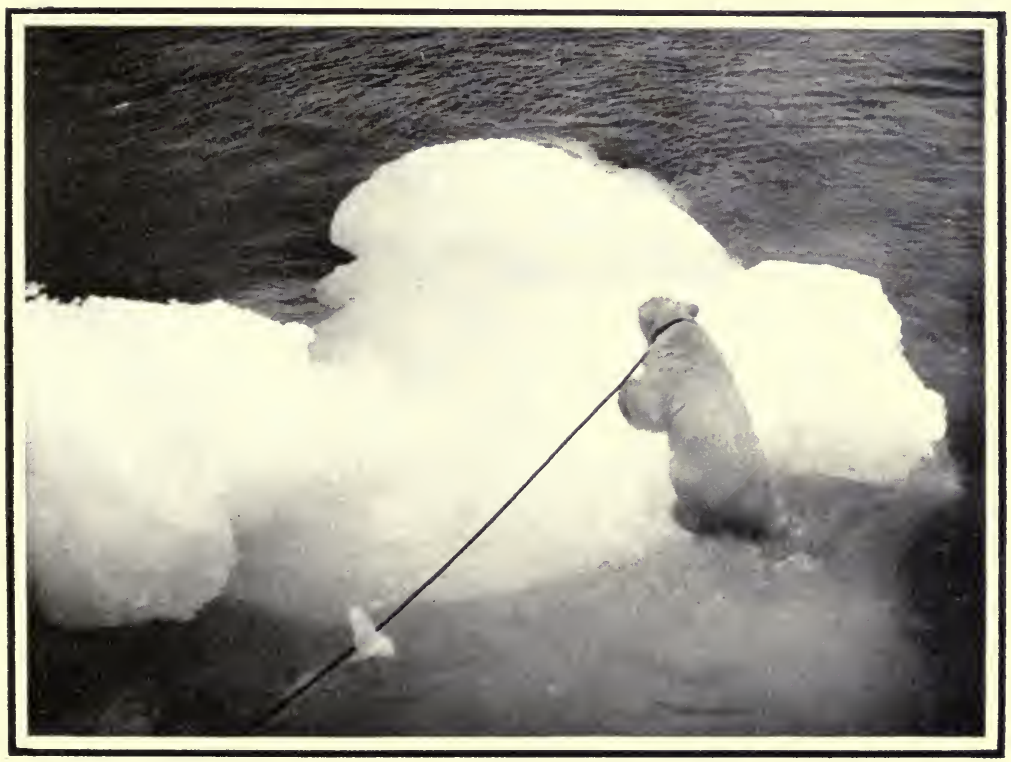

Captive Polar Bear Cub Climbing on to a Drift ice 

us ; we try to encourage him by pointing out the opportunity there is of developing his taste for natural history, and the Seton-Thomson effect at a lecture he might make with even a fair imitation of the language of these large carnivoræ. He and I agree to differ about the qualities of our first two bears. Because our Port bear was evidently interested in the very large male bear which he shot, he thinks it is the biggest, strongest and altogether the most perfect bear for a zoo, and because I lassoed the Starboard bear, I naturally think its dimensions and spirit are superb, and I point out that its three almost successful attempts for freedom are proof of this. Yes, I still back "Starboard" for trouble. Hamilton says Port bear has eaten through more wood than my Starboard bear. I think he is wrong by an inch or two; at any rate my bear has required tons more iron chain, and sacks of nails.

The drifted pine, which we found on the floe weeks ago, is all used up for Starboard's cage; he has torn through three plies of one-and-a-half-inch battens, now over the remains he has chains, baulks of the pine-tree and other bits of timber. At some places the wood is a foot thick, and yet I still back him against the field to get out first.

Getting the bears on deck and into cages, even though they are just cubs and a third of the size of Port and Starboard, was an interesting sight; pathetic if you look at it in a way. Fancy the strength of these little heroes that look about the size of a man. They took six men each and a powerful steam-winch to overcome them. Fluff went the steam and up came the kicking, roaring, yellow-white bundle of strength and teeth, with a strop round its waist, and a line round its neck. Lower away! and the winch reverses and the ice-bear comes down from the sky and is guided to the open top of his cage by the line on his neck led through the lowest bar of the front of his cage, and as he is lowered by the winch two men haul on it, so his head is kept down and his mind occupied with the rope on his neck; whilst other men rapidly nail on battens above his back, then the rope to his neck is cut and he quickly rids himself of the noose-brother and sister are 
side by side — or end on, in one cage, with a partition between them.

Already they take seal blubber, and Gisbert has put a tin of preserved milk into their drinking water. Their poor gums were bleeding with efforts to chaw the wicked ropes that held them by the neck.

Four P.M. The children are now more quiet, one condescends to lick my finger and has accepted several slices of fresh seal blubber, with every manifestation of pleasure, and it carefully licks each paw afterwards, toe by toe.

Now it is my watch for a bear, and I do not feel in the least inclined for more bear, on the floe in orthodox style, or in the water style, which Scoresby cautiously observes "presents a certain amount of safety." He studied in Edinburgh University. A belt of mist is down again to westward and there is a fine fog bow; we are in the sun, but cannot proceed, blindfolded, as it were. We might get into some cul-de-sac in the floe ice.

Odd, is it not, that only a few minutes after writing expressions of disinclination for bear I was working at a poor attempt to get effect of a fog bow in water-colour, and someone shouted "Bear!" and I had to dive for rifle and pistol, tumbled into the boat with four men and rowed away into the sun's glitter. Sure enough the bear was there, swimming across from one tiny floe to another, so there was the chance in the water recommended by Scoresby. We swung along at a good rate and I got it, first shot, in the centre of the brain, at about twenty yards with the pistol, which made up a little for the absence of a stalk. Great was the joy of the men over the $\mathbf{3 8}$ automatic and its deadly effect. To anyone who has not had the excitement of shooting a sitting rabbit, I would recommend polar bear shooting in the water : on a floe in difficult ground there is a chance for the bear, a definite chance, and quite a good chance too for the bear, if the hunter is a duffer. But of course, as compared with rabbit-shooting, there is the difficulty of getting to a floe with a bear on it, and you may be nipped in the ice, or you may die of scurvy, so rabbit-shooting taking it all round may be safer. 
One of the bears on board, the poor little female cub, was most touching, when this pistolled bear was brought on board. She longed for a mother, and tore at her cage to get out to this last bear, a female, but in no time it was skinned and cut up to become our daily food, for we must eat bear now three times a day, our fresh food from Trömso having gone bad and tasteless some time ago.

The mist lifted in bands, and strips of colour came into the sky where the sun ought to have set, but obstinately swung round high above the horizon, and the sea became literally as calm as a mill-pond, and now all the scraps of floe, separating in the stillness, are perfectly reflected. One piece of ice in particular we notice against the vivid lavender with deep bottle-green transparency when the midnight sun shines through it.

As we enjoyed the stillness and mystery of the rising mist, Hamilton said he thought-no, he said he did see land ; and we said, "Oh!" and "Really!" and doubted, but it was!-a little hard point above the low bank of mist on the horizon, and everyone got their glasses out and gradually Greenland became more distinct-no doubt now, mountain-tops, heaven be praised, hills again. We have only been about four weeks away from land; still, that gives one a deep heart-longing for it. We had almost made up our minds that we were not to see Greenland this year, possibly never, but we have seen its mountains! Even supposing the floes close up and gales come, and we are driven back, still, we have seen these icy mountains we promised to see long ago. I wish there were several artists here-there is beauty, delicacy and colour enough to keep all busy.

Possibly the colour and reflections, and the view of mountains appeal to us on account of the many days we have spent in the misty plains of flat ice floe. It will be difficult now to sleep with the thought of land and rocks under foot, saxifrage, Arctic poppies, and possibly musk oxen, and possibly even a mosquito or two, and ptarmigan, and possibly great walrus on the land ice. I certainly greatly desire one splendid pair of walrus tusks. That and a musk ox's head and a narwhal's horn will satisfy me. I do not want a 
museum ; still, there is always some small corner in a house or studio where such things may be stowed to serve as reminders of days in the open.

There is very fine ice forming on the still water; the surface looks as if it had a scum of liquid like melted sugar in an imperceptible form of ice. Other parts are covered with more developed ice-crystals. There is a pleasant, soft, rustling sound, or hissing, as we go through it.

We have a seal or two in view-a hooded-seal we have just got. Don Luis Velasquez made a very pretty shot at its neck at a hundred yards. Now there is a larger kind, a mile



or two off in our line of route; Gisbert will have a shot at it. This thin ice forming now is pleasant enough, but the same formation, if we were here a little later, would make us anxious to get out and off home before it got too strong.

There is really colouring in the sky this midnight, sun reflections, salmon and pink-the first decidedly warm colours we have seen since leaving Trömso. Some of the ice-blocks assume strange tints, one piece with dark lilac pillars supporting the portal of a cave with three arched entrances each fringed with icicles-inside a glory of greens and blues. Did fairies live in this cold land, such should be their palace. 
To-day, 31st of July, in the early morning, we got to within a few miles of Shannon Island, North-East Greenland, and could see the snowy lomonds behind it. Though the land is almost entirely snow-clad, it looks comforting after a month at sea. But the pack ice is too jammed to the west to allow us to land, so we steer slowly south, winding in and out amongst the ice-islands, sometimes shoving a small one aside. We picked up a big seal this morning, a bearded seal, P. Barbata; it is the biggest seal of the Arctic. Still steering southerly, Greenland faint to the westward, with glasses we see fiords and glaciers. Sky and sea silky and still, the only sound the faint pulsation of our little engine. It is hot in the sun ! I can hardly believe it, and yet huge icicles are forming round the edges of the ice-tables. The endless floes grow weari-

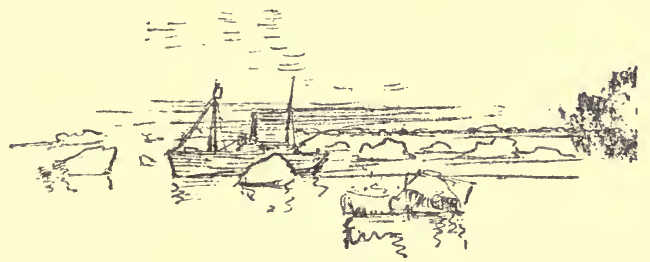

some. There is too little life. There are only a few seals, only a few sea-birds and not a sign of a whale. The pensive sunlit stillness of the day and the mirror-like surface of the ocean were scarcely disturbed this afternoon by the slaughter of two great blue seals. The largest showed that a bear had lately paid it attention, by the cuts on its enormous body. It weighed on the steelyard three hundred kilos, equal to six hundred and sixty-seven pounds; about the weight of four policemen. A big bear with one paw can lift such a seal out of the water and throw it several yards on to the floe. The blue seal is rather like the Barbata or bearded seal, excepting the colour of its coat, which is more brown than the blue seal's. Each has a very small head in proportion to the bulk of the body, both have only rudimentary teeth, they eat crabs and seaweed. Whether the teeth are provided for the purpose or whether the seal is restricted to such small fry because it has such poor teeth, is perhaps a 
matter which would be best discussed at the Royal Physical Society in Edinburgh or London after lunch.

It may seem discontented, but I must confess this prolonged fine weather (we have had seventy-two hours of the same white sunlight) begins to get a little on our nerves. Nature here is so extremely mathematically laid out. The sea is polished to a high point, all the little cloudlets are arranged in such order that ribbed sea-sand would be quite irregular in comparison. So of course

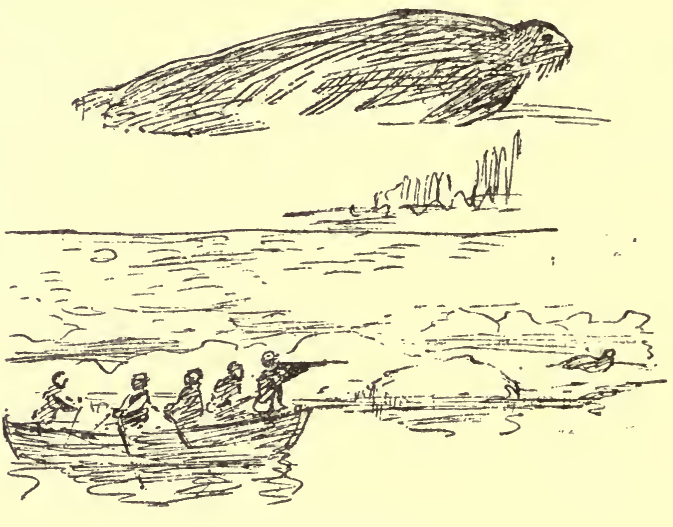

Phoca Barbata you have these cloudlets, level bands of pale blue and some faint yellows, all repeated in the mirror. Very high-toned delicate colour, but, if I may criticise, just a little sickly. I think with the advance of years one does not find these extremely delicate harmonies quite satisfying, one rather longs for ruddy, tawny colours and tropic blues in their deepest notes.

It is so calm, so stagnant, if I may say so, that our thin brown smoke hangs in wisps where we left it many hours ago. And yet for all the smoothness and polish there is an untidy aspect, for there are little and great bits of ice floating all over the place. There being no wind, little scraps of ice and big bits get all separated, and each takes up a bit of sea to itself. When there is any wind these pieces herd or pack together. We trust that the ice along the shore may soon follow this example, for it is only pack ice, not the fixed shore ice of winter. We hope it will disperse in a day or two and let us inshore to see " the saxifrage and poppies."

With the glass we frequently look at the faint far-away mountains and glaciers. A little while ago I thought in the 
silence I heard a shot from away over there, thirty or twentyfive miles off-no, it must have been a glacier cracking, a berg calving, perhaps. That sound carries in such weather a tremendous distance, and so too does the wave made in the sea by the ice-cliffs falling.

Vessels lying in calm several miles away from such glaciers have been nearly swamped with the wave raised by a calving berg.

The evenings are now, on the 1st of August, just distinguishable from the day by a little increase of yellow in the sky and pink on the snow. To-night the sea froze over with a thin coat of ice and we go rustling through it.

Later, about twelve o'clock, we were in an open lane, between floes and no thin ice, where a family of narwhals seemed to be working for their living. So we lowered a whale-boat as quietly as possible and rowed gently after them, and as usual, just as we got, say, to within forty yards, and held the harpoon aimed ready to drive it into the biggest bull, say at twenty yards, for they show very little above water, they quietly slipped under for other ten or twenty minutes, and then appeared several huridred yards away. With modern big harpoon-gun from the bow of the small whaling steamer, we can harpoon from thirty to forty yards, but in shooting from the bow of small boat close to water's level the range is more limited. We tried waiting, following, and circumvention, and when we tried to cut across their course, one of them broke water actually between the oar blades and the boat and made a great swirl ; and evidently this too close contact scared the family party, and they all disappeared, and we went on board, still hopeful, however, for three times at least we had been within a second, or say two yards, of our chance of securing a great white ivory horn.

... Our patience was tried again and the writer's was found wanting. I had turned in and heard the boat being lowered away, and let a crew go without me, and never heard them come back, though there must have been thunderous treading of sea-boots on deck a foot above my head, ropes falling and blocks rattling-you can sleep soundly here when you get the chance. 


\section{WHALING AND BEAR-HUNTING}

But C. A. H. complains that he cannot, for, poor man, the two new bear cubs are almost touching his bunk, and their scrape, if not very loud, is pretty constant, and bear perfume permeates his cabin even more than the rest of the

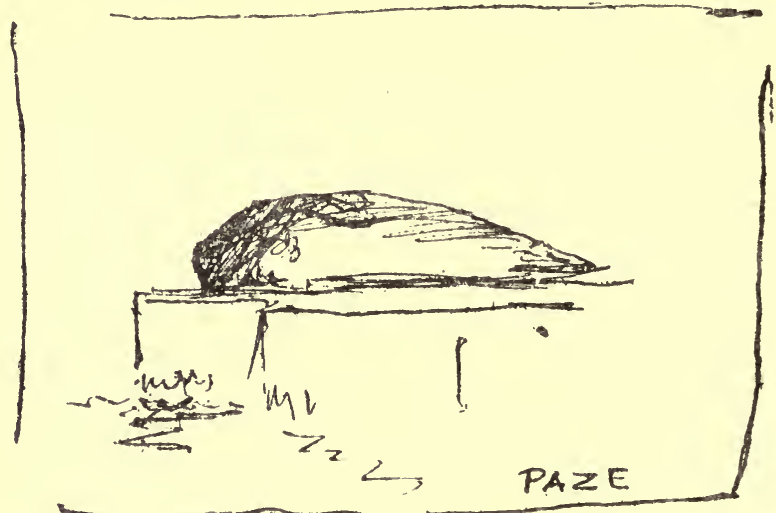

ship. But praise be, there is a light breeze to-day from landward. I have not yet observed any scent of saxifrage or Arctic poppies, but it has freshened the too still atmos-

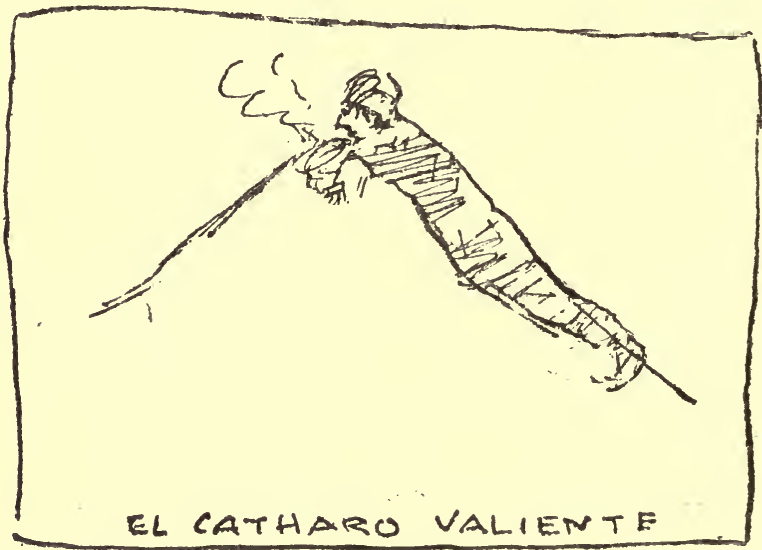

phere and we hope it will help to open up the land pack and let us land for musk oxen.

Our starboard bear raised Cain! almost all the wood of his cage is chawed up, so round the inside of the remainder

Note.-For description of above drawings see pp. 274-275. 


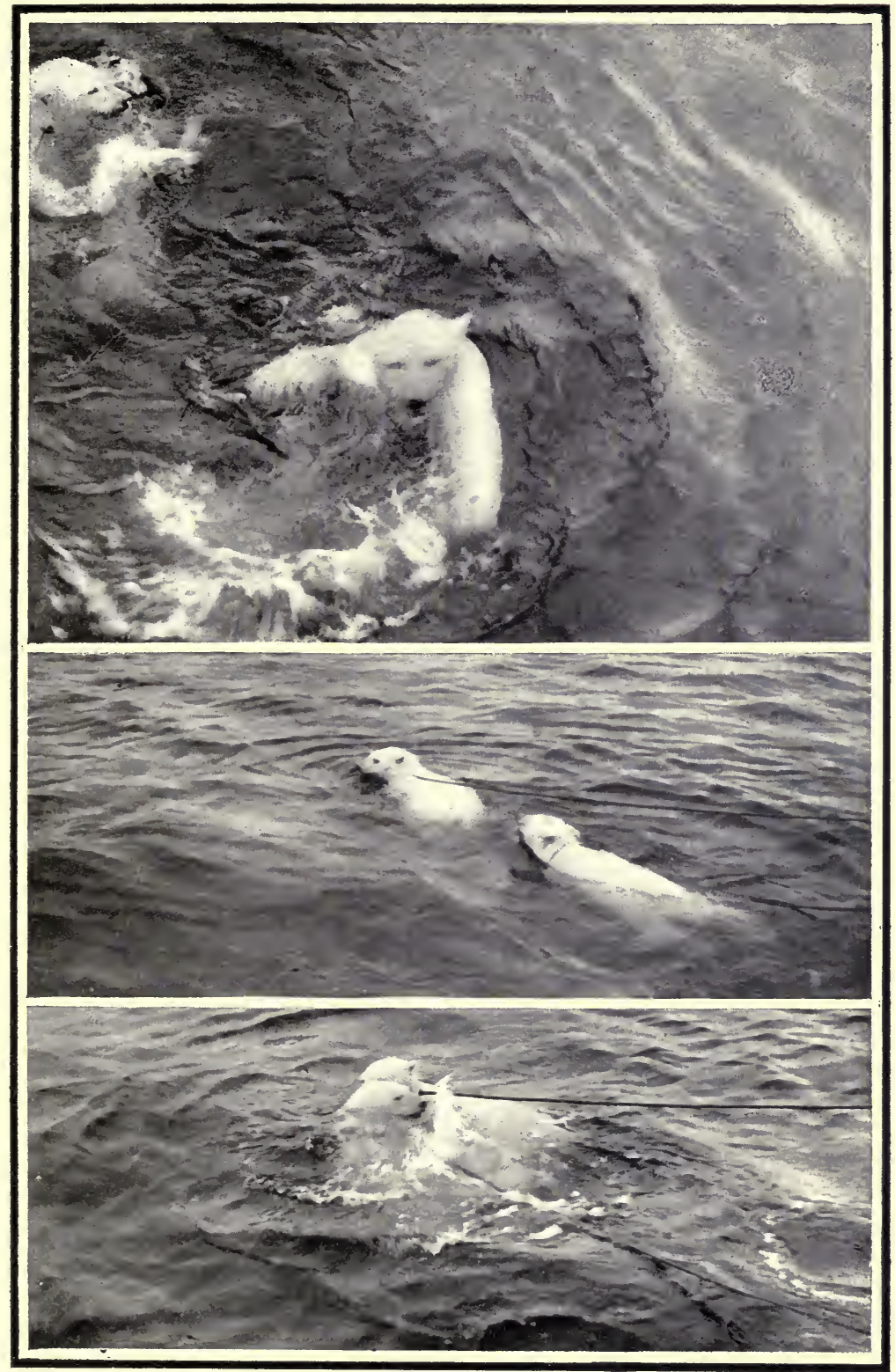

Shows Captive Bear Cubs, Brother and Sister, and Ice Beginning to Form on the Sea Water 

we have hung heavy iron furnace bars and other round bars, holding the furnace bars more or less in position, there are ropes, chains and wire round all-a horrible sight, for the poor fellow inside, with all his struggles and the black of the furnace bars, is quite black, and he has lost a lot of hair. I would give a good deal to see him free again and over the

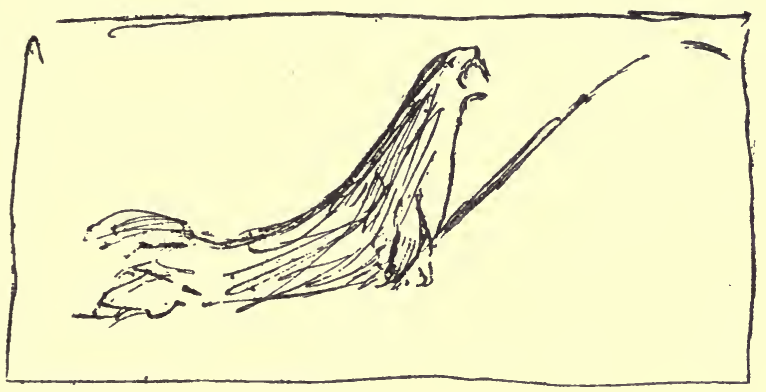

side. But I pray heaven he does not settle his account with me before he goes for having roped him into his present sad condition. I believe it was the noise of the fight he put up that awakened me this morning, at least what I heard made me look out, and sure enough there were six men struggling with crowbars, hammers, axes, etc., etc., and then poor

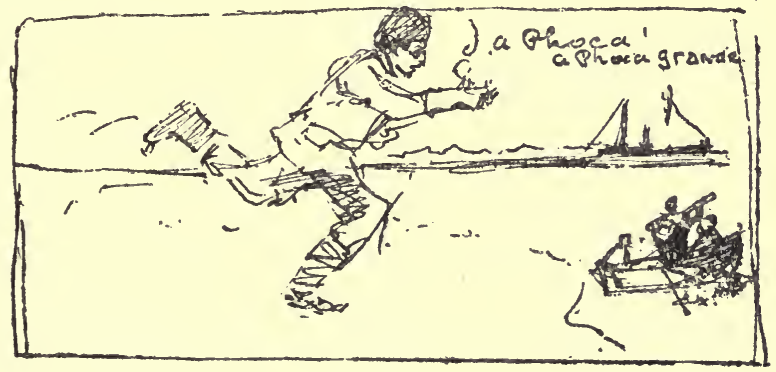

Bruin's black head appeared between timbers and nails for a moment, till he was again closed up. It would take a couple of months of the ice and snow to clean his coat again.

In the afternoon-now he is almost quiet, for when he tries to claw at the wood through the cast-iron bars they fall back into place again, and he cannot eat iron! So he is 


\section{WHALING AND BEAR-HUNTING}

thinking now which is the weak point; in a day or two he will attack it. I am very sorry for him, now he is quiet and a little red shows where he has been scratched. I can imagine, like the old Scottish fighting Admiral Barton, that he murmurs:

"A little I'm hurt but not yet slain, I'll but lie down and bluid a while And then I'll rise and ficht again."

A mist came over the scene this afternoon, with light shining through, but enough to stop us making progress, even should the ice-pack allow us. So we

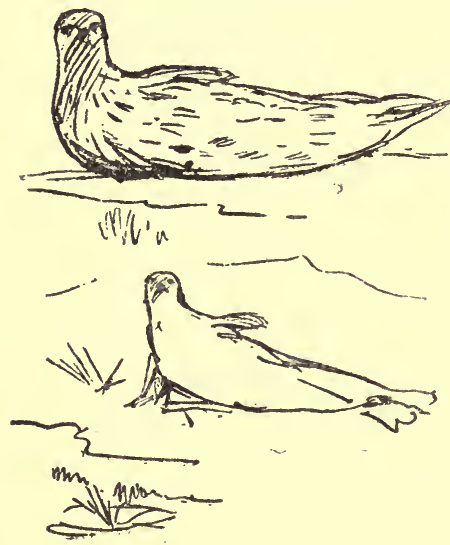
moor fore and aft alongside a small floe and set to work with pails to fill our fresh-water tanks from the three blue pools on it, pale blue flushed with lilac, cobalt round the rim of each. We stroll on the hard snow, stuff like coarse salt laid down on a blue translucent carpet, and play the pipes, and play with Chee Chee, the ship's pet. The only game she does not like is being lassoed. Finding a mit

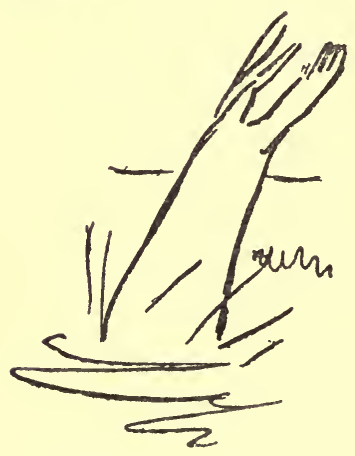
hidden in the snow suits her, and a great many other games taught by various instructors.

Our youngest Spanish señor ventured to row away from the ship a little this morning, and this the youngest Don Luis Herrero told me a fine yarn about how he had come on a splendid saddle-seal unexpectedly-that is a dappled

brown and white kind we have not got as yet; he described it vividly as seen from five yards. Gisbert at lunch told me it was a make-up, therefore the writer tried to pull his leg in return by illustrating his pretended encounter with the famous seal as per marginal notes. (See p. 272-273.) 
You may not think it, but such a small attempt at an amusing drawing caused laughter on board. You see a little joke goes a long way in the ice-pack, as for instance the drawing below.

The only mild excitement to-day, 2nd August, was a boat expedition, with los señores, two rifles in the bow, and two pairs of oars, against a large harp-seal, with a splendid white skin and large black spots, suggestive of an Al carriagerug. Fire opened at a hundred yards (the first shot was accidental), but several struck the water quite close and in front of the seal, which made it take up a very indignant attitude, and for an instant it seemed to hesitate as if it thought a retreat on to the floe would be its safest course. But a bullet finally hit it in the back and it acted on its first intention and dived off the floe. The two Don Josés were rather disconsolate, for certainly it had a very beautiful skin. We hoped to get quite a lot of these large harp-seal skins and their blubber to fill our casks.

The harp blows his nose up in a remarkable way, so hard that it inflates the fore part of its head. Naturalists assure us that, like the shark's fin, this has an awe-inspiring effect on their opponents. We accept this cum grano salis. This is what I remember of the harp's attitude and expression (1) before he was actually fired at, (2) its attitude of astonishment, and we may call the next his adieu. These designs are executed, you observe, with a certain chaste economy of lines. (See p. 274.)

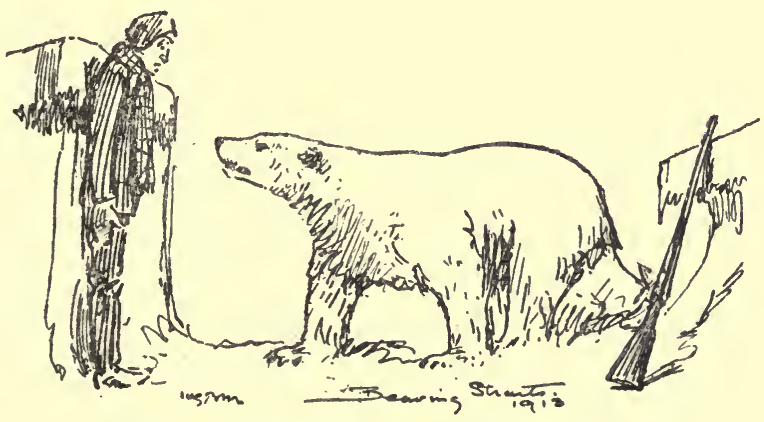

An Incident from " Bearing Straights." 


\section{CHAPTER XXXIII}

DINDING no whales and being unable to get on to Greenland, for some twenty miles of ice now separate us from its shore, we decide to turn back.

Right about wheel then, for we are sick of eternal flat icefloes. If we had a new boiler, new coal supply, new food supply and unlimited time, we would hang on. The ice may open in ten or twelve days, but we arranged to finish our hunting, if possible, at Trömso, Norway, about the middle of August. So we have just time and no more to get there by that time, granted there is fine weather and little fog.

But as I write, seven P.M., we are again into a fog bank and have to tie up to a floe. It is thin fog, and sun shines through it and we hope it will lift. So it is good-bye to our chances of whales, musk oxen, or walrus, for walrus we can only get along the coast in shallow soundings. One whale, and that only a narwhal, is our poor basket. We must console ourselves with having got a fair number of bears in the time-seventeen in the month, one narwhal and a lot of seals. It will not pay, but we may yet get bottle-nose down about Jan Mayen Island, if the drift takes us southerly in that direction before we get out of the ice easterly.

Perhaps I may here be allowed to put down some notes on the protective coloration of the Arctic fauna.

Evening of the 2nd August. We thought we were in for another bear this evening, because a young man on watch probably mistook a piece of yellow ice for a bear, and we went back on our tracks, but found no bear. We hunted round the floe on which he vowed he had seen it, but did not find even spoor, so I fear his cry of "Wolf " will not be listened to for many a day. Naturalists tell us that the yellowish tint of the bear's skin is given to it by Nature to allow the bear to secure its prey, the seal-that the seal is green enough to mistake the bear's skin for a piece of yellow ice, and thus the fittest 
survives. As these yellow pieces of ice are few and far between, and as there are far more pieces of blue ice, and as the predominating colour of the snow is white, I'd have painted the bear blue and white if I had been Nature, with only a touch perhaps of yellow here and there.

Naturalists have also told me that whilst waiting for a seal at its breathing-hole in the ice, the bear covers its nose with its paws to prevent the seal seeing the conspicuous black of its nostrils. I should think myself this is to keep his hands warm. Five black claws on each foot must be as conspicuous to the seal as the black nose. Again, sometimes a bear covers itself completely with snow, all but its nose! This allows man in his turn to have a chance of proving himself to be the fittest. A case in point was when two men I know up here encountered a bear. It took careful stock of them and did not like their protective smell or the checks of their tweeds, so it did not immediately attempt to eat them (possibly it was not hungry), but it retired, as it thought, out of sight, and with a few grand sweeps of its great forearms and hands covered itself up with snow, only leaving its black nose exposed. But for this wonderful foresight on the part of Nature in making the bear's nose black, the order of evolution might have been reversed. Man strolling along and seeing nothing but white snow might have slipped out of existence in the warm embrace of Ursus Maritimus. The protective coloration of the black nose, from the man's point of view, surely proved that Nature originally intended the bear to be cooked with onions for our dinner.

When they spotted the black nose, the two men proceeded to guess in which direction lay the neck and body. (I think only an artist who has studied the drawing of a bear's nose and head could have told for certain.) So when they did hit it in the neck, it must have been rather a fluke! It was a fighting bear, and came out of the eruption of snow with fearful roars, and in a great hurry, for a bear. But Nature insisted on the evolution and survival of the higher species and wiped out the bear with two 475 decimal bullets, nickel covered, and added, very incidentally, vermilion to the 
general colour scheme of the floe, tempting one to drag in the trite quotation: "Nature red of tooth and claw."

We are inclined to dwell at some length on the theory of the protective coloration of the fauna of the Arctic and the Antarctic regions. For in these frost-bound portions of our sphere there is frequently so much fog, or nebulous condition of the atmosphere, of such density that the naturalist observer is compelled either to evolve theories or play cards.

Another of the carnivoræ of these high latitudes, Vulpes lagopus or Arctic fox, has also by Nature been given a remarkable skin as protective colouring of perfect whiteness (value to-day about £12). Beyond doubt, as with the bear, this resemblance of the colour of this skin to the surroundings is in order to allow the fox to secure its preynamely, the Lagopus hemilencurus or Arctic grouse, of which it is particularly fond, as also of the Lagopus glacialis or white hare of the polar Arctic regions.

Now, seeing that the fox is singularly gifted with cunning, a fact which has been universally admitted by naturalists of all times, Nature, to prevent the complete extinction of the smaller fauna, such as the hare, which has neither wings to fly with nor fins to swim with, has also gifted the hare with a white coat, and so the balance of Nature is preserved. In the case of this Lagopus hemilencurus or Arctic grouse, which, unlike the fox or bear, is unprovided with teeth with which to protect itself, Nature, with its unstinted bounty, has provided it with lateral appendages, one on either side, with which it is enabled to fly; thus it has, besides its protective coloration, another means by which it can escape its natural enemy, so the preservation of the less cunning but more edible species is preserved. We might perhaps have thought that, being provided with wings with which to take flight, the protective coloration for this bird would have been unnecessary, but we must remember that the fogs of these high latitudes, which have already been alluded to as affecting the actions of the higher animal homo, put this bird to a disadvantage. For it has been stated (the writer need hardly quote his authority here) the nebulous conditions referred to in these high latitudes are sometimes of such density that 
they may actually prevent this bird from seeking safety in flight. This being so, we can the more readily understand the necessity of the protective coloration for this succulent bird.

As an example of how very thick such a fog can be up here, it is related by an explorer (an American, I believe) that the men on watch on a certain occasion on his vessel were sitting on the bulwarks smoking their pipes and were leaning against the mist, when suddenly it rose and they all fell backwards into the sea.

What may seem unaccountable when you consider the bear's protective coloration is that seals of various kinds in the Arctic regions should have apparently no protective colouring. Whilst lying on the ice beside their holes they form quite conspicuous objects, even at a distance of a mile on a clear day, and less if it is foggy or on a dark night. But the reason for this apparent contradiction is not far to find; for, as we have already explained, owing to the colour of the bear's coat being of a yellowish tint and occasional pieces of ice being also of a yellowish tint, with a far-away resemblance to the bear's coat, the seal takes the bear for a lump of ice walking, so Nature here has stepped in and said to the seal: "If you are such a silly fool as to mistake a bear for a piece of yellow ice, why, have a dark brown coat and be blowed to you," so everyone is pleased-and so on.

The bear, or supposed bear, of last night, interrupted a quiet, misty evening we were spending alongside a small floe of a quarter of a mile in diameter of hard, smooth, frosted ice. Our men were occupied drawing fresh water from the blue pools. Eastward lay mist, north and west a pale orange band just showed beyond the violet-coloured floes and soft grey sky, just the quiet effect for decoration of a silk fan.

On the smooth floe we held various sports, tossing the caber, for example, the caber being the remains of the pinetree we found on a floe as we came north. Also we had fencing. As there was rather a pretty small blue iceberg alongside, C. A. H. got his camera and photographed the two champions. The too-strong she-cook went a walk with Chee Chee; a little trot, rather; she must weigh about 
two hundred pounds, but she rather trips than walks. I wonder what a bear will think of her if he meets her. She is broad and deep-chested, with round red cheeks, and has a gentle voice and a gurgling laugh any time in the twenty-four hours of daylight. There was also a little pipe-playing, so the smooth floe with the blue pool was quite lively, till the call came to bear arms! Then everyone but Chee Chee came on board, and it stood alone, with all hands saying

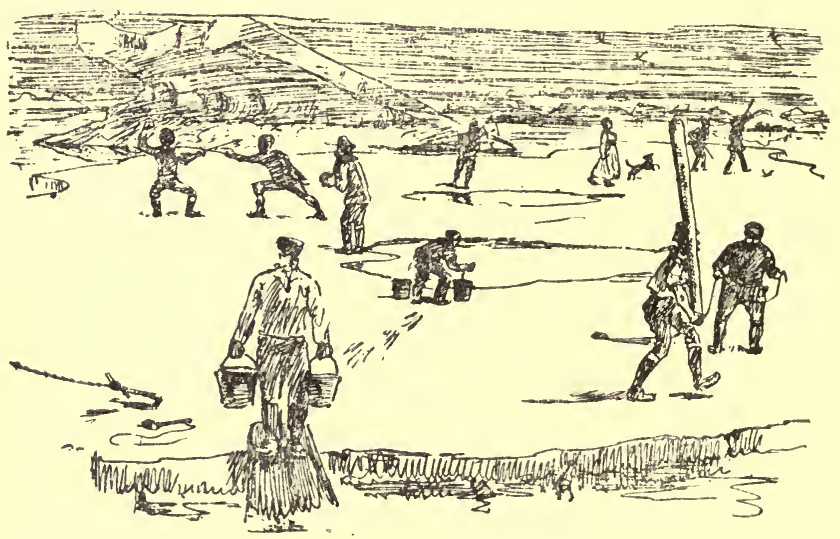

endearing things to make it come on board. Whether it was my seizing the lasso, the sight of which it hates, or one of the men circumventing it, I would not like to say, but from one reason or the other it came with a sudden bolt-I think the lasso did it !

I nearly forgot to put our Spanish friends into the picture ; here they are, there is just room, right-hand top corner, hilariously shooting skuas, those robber birds. The señors are jolly the clock round; what a fallacy that is, about "solemn as a Spanish Don." 


\section{CHAPTER XXXIV}

CHERE being still mist this morning our budget of news can only be described as strictly Local, for we

1 can only see over a few yards of floe and rippling sea. Three hooded-seals appeared astern just now, as I went out for a breath after completing the aforesaid masterpiece of the floe-edge scene. They went off with a splash, as if alarmed at finding themselves near us, and then they came up again and took stock of us at about two hundred yards. We could not see them well, so we did not shoot. What we may call Home news, is of our cubs forward. William the (comparatively) Silent worked through his floor, and it had to be renewed. We call his sister Christabel, for she bit her brother's face without any reason; but it is rather unfair calling her so, for he certainly threatened her-thought she caused all the troubles he had had in his short life. She refuses to have water. Even when we pull out her watertrough she violently draws it in again and upsets the water. She has strength! I think she will be a great catch in a zoo, where her pretty ways could be studied behind bars with safety. The old Starboard bear is now mastering the material iron; teeth, he has learned, are no use, so he is applying brain. He eats sugar from our fingers, and would eat hand and arm with half a chance. I begin to sympathise with him in regard to confined quarters; even the wide space we have of about three square yards of deck, in which to have our exercise, feels confined after about five weeks' time.

I forget what we did or did not do in the morning of Sunday, 3rd August. I expect, the same as usual. There is thin mist, with sun shining through, an unhealthy mouldy morning, and we have a feeling as if we had had bad champagne the night before - a slight nasal catarrh, and a little sneezing going on amongst your neighbours and several complaints of rheumatism, cuts, and boils. 
I have always heard the Arctic likened to atmospheric champagne, where men's spirits are said to be high and colds exist not. Well, all I can say is that in this particular vessel in these latitudes (there again, there's someone else sneezing) there are many such complaints, and smells ! Hamilton says " The look of the sea suggests a smell." It suggests to me London on a November morning. Sea and air are so stagnant and cold, you could lean against the icy smell of our bears or kitchen, and a cigar whiff almost strikes you.

When the sun got up we steered away east and south-a hundred and forty miles we have yet to go, to get out of ice into the open sea, "the rough highway to freedom and to peace," as Morris puts in his Jason, and all day we passed down lanes and lakes and across belts of deadly still water between floes of flat ice, with few and small hummocks. And seals became plentiful. As far as the eye could reach,

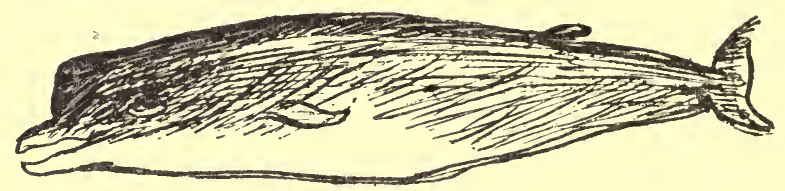

occasional black marks could be seen on the floe and little black bullet-heads appeared in calm water at the floe-edge, and some of them came and examined us from thirty or forty yards as we passed, for an instant, and dashed under water again, leaving a swirl like the rise of a ten-pound trout.

Yes, I think that was the whole day's programme, excepting an alarm for bottle-nose whale. That came in the middle of aften-mad, seven or eight P.M., and we hastily loaded our two bow harpoon-guns, and got all ready and waited and watched, but the bottle-nose did not appear again. In several books on whales I see very misleading drawings of the bottle-nose whale, Hyperoodon diodon. This one is taken from notes of these whales in various seas, alive and dead.

We were about to lay ourselves down to rest when a shout that a bear was in sight came from the mast-head, and all of us became very much alive.

It was on a floe a mile off, and the floe was peppered with 
seals, and it lay on its back and turned up the black soles of its feet and rolled about, apparently quite pleased with its own company, and indifferent to the seals.

A remarkable thing happened when our little body of hunters set out after it - the seals lay on the ice, without popping into their holes, also other seals came alongside to within ten yards or so of the Fonix. It looked as if they knew that we were men bear-hunting. This struck me as odd up here. Of course in the Antarctic there would have been nothing remarkable; and Gisbert, who has been in Arctic ice scores of times, also thought it unaccountable, unless it was actually the case that the seals knew that we were in pursuit of their enemy.

Still another thing extraordinary happened-we were watching the great old fellow stretching himself, and all his movements through the glass, noting his colour, light warm yellow, lighter than the violet of the floe in shadow! when he raised his black nose and face and went off at a walk to the left. I am sure he had not seen our guns or smelt them, it must have been that extra sense which the black bear also possesses-instinctive knowledge of a presence. Soon he came to a place where two of our men were visible to him and then, Hamilton tells me, he went off at a gallop! A great big male bear! It is a rare thing to see a bear gallop, I just missed doing so-took my glass off to make a note in colour, and he had got to a walk again when I put my glass on again. He made off fast to the left, where the floe ended, and about half-a-mile of calm sea and small bits of floe separated it from the next floe. This manœuvre left the two guns and the men far behind, so, to prevent his escape, we lifted our ice-anchor off the floe and steamed away to cut him off, and we got between him and the next floe when he was about a hundred yards from it, and so turned him back - a great big fellow swimming strongly, making a dark green wake behind him across the smooth bronze colour of the water-his last swim up the golden track of the midnight sun. Poor old man, the orange rays touched his pale face, and he looked anxious. I think the seals knew he was in difficulty, for several swam quite close to him, their 
natural foe. We dropped a boat for the guns on the floe and they soon came up and opened fire at about twenty yards, and by-and-by a well-aimed shot hit in the neck. It is a male bear of great size-what an ignominious ending! But if you only think of the killing part, what hunting could be called sport? After all, it took Man much work to circumvent this ice bear-a ship built for ice work, then the engine, coaling and provisions for a year, and several weeks' navigation amongst the risks of sea and ice combined. He weighed eight pounds short of a thousand, stood on his heels from nose or eye nine feet two inches. He bore two old wound marks on his body, possibly made by Eskimos; we wonder if it was the memory of them made him go off so quickly; possibly it was only hunger and thoughts of dinner that at first disturbed him, for he had only a little seal's skin inside him.

It was the first time I had seen a bear look lighter in tone than the background; the sun being at a low angle, the undulating surface of floe was all lilac and tints of pale green, and yellow, and only the raised hummock and projections and the bear itself caught the golden light. The shadows on the bear's body were comparatively dark green. So many people paint bears, and so few people see them in their natural surroundings that these colour notes may be pardoned.

From one A.M. to five-thirty P.M. I heard at intervals in my sleep my Spanish friends fighting the battle over again, and occasional shots at seals. Their vitality is extraordinary (the Spaniards); they can talk for hours and hours without evincing the least sign of fatigue, whilst we poor northerners are creatures of habit and feel ready for bed after eighteen or twenty hours' hunting; and we get tired of talking in a fraction of the time they spend yarning.

They are rather bull-ring enthusiasts and back their bulls against any bear. Gisbert plans capturing one of these full-grown wild bears that are never seen in captivity and taking it to Madrid-more easily done than the reader would at first think, but it would be real sailor's work. First of all you would find your big bear on a floe, which you could sail 
round-easily enough done-and by one means or another get him to take to the water, also easily done. Then follow him in two boats, each would throw a lasso over his head, when the interest would begin. Whilst number one boat hauled taut he would probably roll over and thrash with his paws, then number two boat, with loop still fast to his neck, would throw a hitch over a foot, and so haul the foot to his neck, and so on with the other fore foot and hind feet; his head would then sink and hitches could be cast all over him, till, like a fly in spider's web, he would be helpless. Then the big strop round him and a strong winch chain, a hold lined with iron plates and you would have such a bear as has never been seen in captivity, a floe-bred bear, say twenty years old, of huge dimensions. Gisbert, who knows all about bears as well as about bulls, backs the bear in the ring; so do I. Its four enormous limbs, each with a hand and claws on them, a neck and head and teeth of enormous power, all told three times the weight of a bull, and combined with cat-like activity and quickness of eye. Possibly next year this may come off and Hamilton and I will go down to Madrid and make a book, for all Spain would give any odds on their bull. In Madrid an elephant was pitted against a heroic bull; the bull at once charged and prodded the elephant, which annoyed it so that it swung round and broke the bull's back with a swipe of its trunk. But a lion or black bear and a tiger the bull has easily mastered. A lion stood the charge and was lifted clean into the air and came down and bolted inside out with its tail between its legs. A tiger ignominiously fled, chivied by the bull all round the ring. So Madrid people are prepared to lay their shirts against any polar bears, or anything under the sun; they are in honour bound to do so.

The bears they have seen in European zoological gardens have been brought as cubs, or at oldest were two years old, when they left their native floes, and are narrow chested and have narrow hips. Wait till they see the enormous proportions of chest and hind-quarters of a full-grown fellow that has lived, say, twenty to forty years, up north, with boundless liberty, on full rations! 
Hamilton backs the bear to take a picador and horse under each arm, and the bull in his teeth, and our young Spaniards are a little offended at the picture, mais nous verrons, perhaps as soon as next year, if De Gisbert comes north hunting another season before the Spanish Government expedition starts.

We continue to make our way towards the edge of the ice through the mist, till we come to quite an open space of several miles in width, where the slight roll from south-west tells us of the open sea to come, and we talk of our hopes of a smooth crossing to the north of Norway. The Dons make preparation for retirement, and divide their beer, apples and chocolate, kindly offering us a share. With great forethought they have preserved these provisions against the expected confinement. But I trust it may be sunny and smooth, for their sake.

This day, the 5th of August, it is really hot in the sun, and there is a light air behind us, and there is only a very long, almost imperceptible swell-the sea silky blue, with delicate ripples, and the pans of floe ice are moving visibly, slightly dipping and rising, and the blue sea swells green over their white, as they rise, and hundreds of little streams run off them like icicles. "This end of the garden" is to-day very fresh and delicious, and after all these weeks of fog and nasty weather we hang up our bodies, as it were, to dry, and lay out our souls to the sun and thank the Creator for life. Life in a fog in the Arctic in the part where we have been is small beer, it is impossible to be truly thankful for the permanent possibility of sensation. 


\section{CHAPTER XXXV}

FTER several weeks' trying to get through the ice we failed to get ashore, owing to there being twenty to sixty miles of fixed land ice, and now have worked our way back eastward through three hundred miles of pack and floe ice. By luck we might have found part of the coast free of ice, or only a few miles of it, but apparently, instead of this drifting south and giving some rain to the British Isles, southerly and easterly winds have held back the South Polar ice-drift. Eight to ten miles off the coast of Shannon Island, on the north-east of Greenland, was as far west as we could press; other navigators have taken almost the same course and have found as little as only fifteen miles of ice to shove through between Norway and Greenland.

Yesterday we got the open sea and swell and now, as I write, we have come in contact with ice from north of Spitzbergen, and the ice from Siberia coming round north and south of Spitzbergen, and it is so plentiful that we are obliged to go north-east to find an opening easterly.

All afternoon we have been trying to find an opening and till six or seven could not see a way through, and ice coming from north jammed us considerably, but it was light pack, not more than four or five deep, so our ship, little as it is, was able to hold her own. You could by its thin and flat appearance at once distinguish the Spitzbergen ice from older, heavier polar ice, which we just left to the west.

Now, at seven in the evening, we have struggled through, and are leaving all Arctic ice behind. The pieces get smaller and smaller as we approach the open sea, till at the sea-edge there is only a margin of, say, a mile or so, studded with small pieces a few feet wide, and then again there is a further margin still smaller, remnants that were once hummocks or even parts of some iceberg. Then even these faint sentinels of the Arctic fade away behind us in a pale line, 
and we are free and in a handsome, rolling, free-born, deep-sea true-blue ocean swell. Everyone is pleased. One is bound to admit that at any time in the ice there is, especially to one who knows about it, an indefinable sense of strain. This strain, slight as it is, expresses itself in our crowd. De Gisbert is playing "'The Cock o' the North" on the mouth melodeon, with great go ; the writer has just adapted the old sea chantey to the bagpipes, "What shall we do with a Drunken Sailor," and a violent desire to excel at lasso-throwing has seized Archie, and so on.

Even our home, lately so sedate and dignified and restrained in its movements in amongst the ice, has taken a jolly seaman-like lurch and roll. The crow's nest and mast, shining in the sun, go swinging to and fro across the skynow she puts her nose down into the blue, pleasantly, and rises and our old level horizon of the ice days is away below us as our bows point to the skies-right and left we roll and we swing her south-east, for habitable land, for Trömso and Trondhjem and green trees growing and new fresh food; for even a few months in the ice with food getting rather stale makes us hanker a little after a new kitchen. We are tired of eating bear and of looking at their legs, which adorn our shrouds, great red-black limbs that we see all day swinging against the sky and eat slices of at every meal. Eating and seeing dead bear and hearing and smelling the living captives twenty-four hours of the day is too much of a good thing, so this is why we hanker after a new kitchen.

I dislike a storm at sea, but I do confess I love the sea when it is smooth and blue, and it soothes you with a long gentle roll such as we have to-day.

It looks as if we were to have a smooth crossing to Norway, still the fiddles must come down from our cabin walls and again grace our little table. For in a small boat such as ours every yachtsman knows that they are inevitable whilst deep-sea sailing. Gisbert cleans his rifle and the fiddles are on the table! so we are really done with the Arctic in the meantime. He and I each used our rifles an hour or two ago in the ice. No one knew who was to shoot at a seal on a floe that possessed a coat we all envied ; we were rapidly passing, 


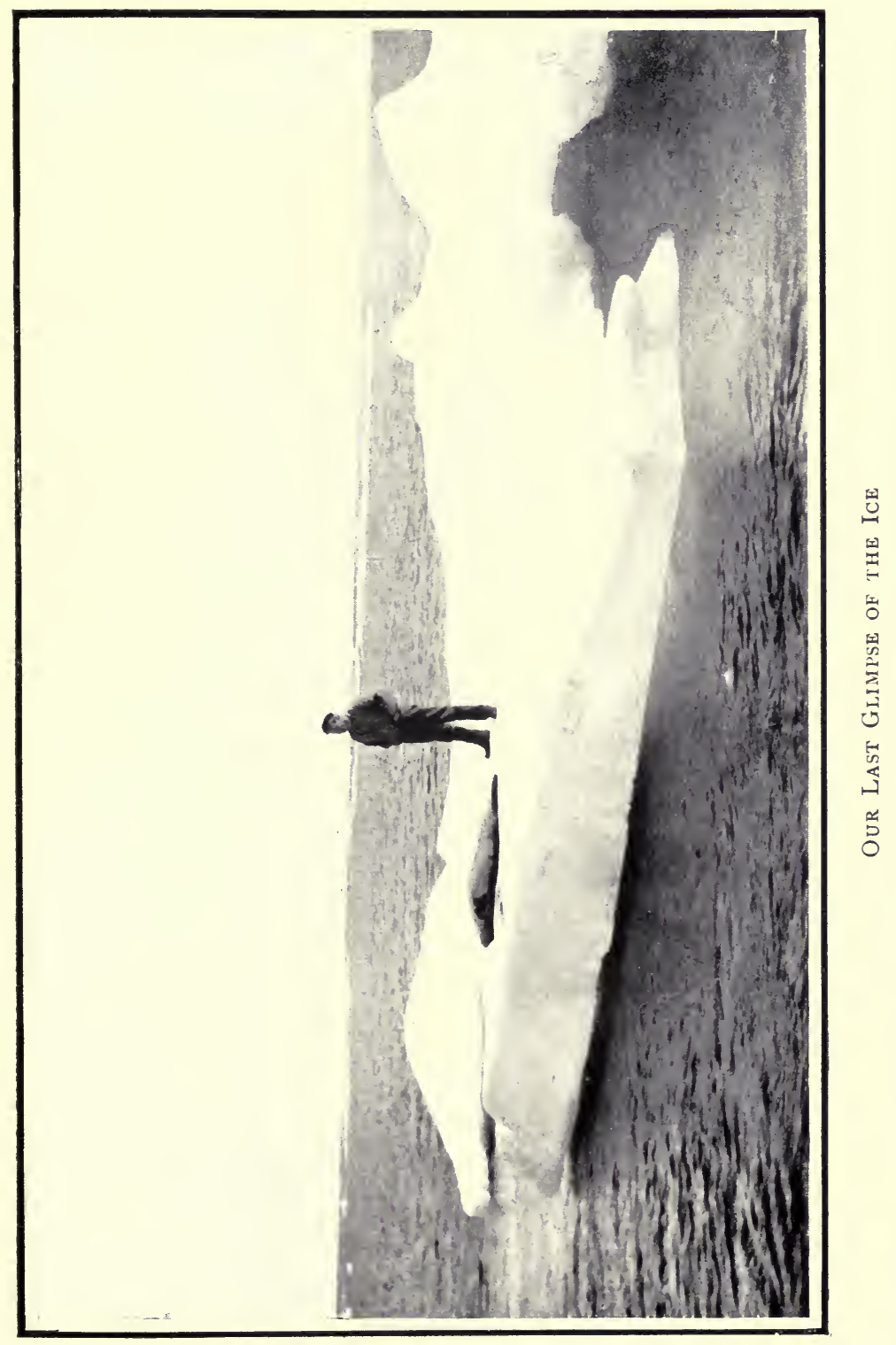



so someone had to shoot and that quickly, so Gisbert and I dived for our respective rifles, and each loaded at the same instant and each fired as we swung past at eighty yards, and each within the hundredth part of a second, and each hit the seal in the middle. Neither of us knows which was the vital shot. We shoved the ship's head against the floe and a man clambered over the bow and made a lasso fast to the seal. It seems a small matter to pot a seal on an icefloe, but I would give many pounds, shillings and pence to be able to pass on the beauty of the colouring of that chunk of ice and green and lilac reflections in the purple sea, the silvery grey of the seal sparkling in the sunlight on the snow, and the reflected white light on the pink face of the man who

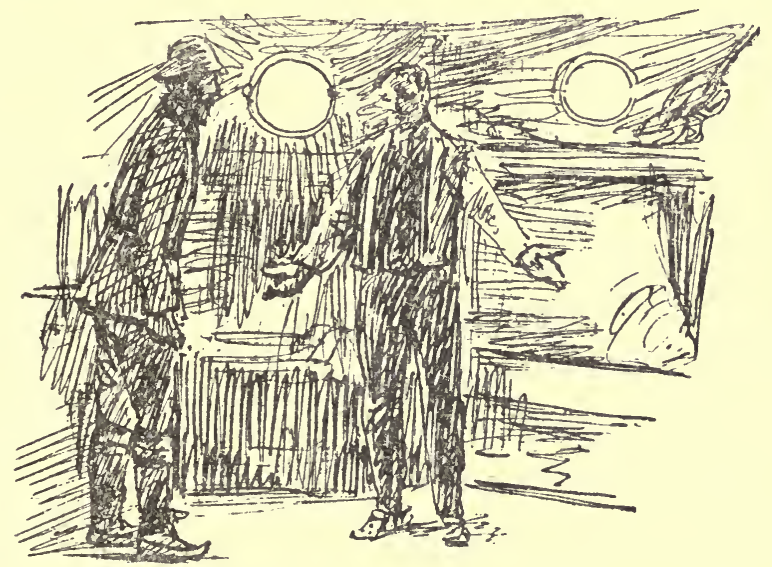

jumped on to the ice to bring it aboard. The Prophet, we call him, a typical Norseman, with blue eyes, bushy yellow eyebrows, yellow hair and a kindly expression-he may be thirty years old, he might be a thousand-he is a type. His prophecies almost always come true. "It will be better before it is worse." "We will get another bear before Gisbert cleans his rifle," and so on. Remarks such as above are more interesting in his broken English-our steward's broken English this morning almost rose to the level of punning. Archie Hamilton asked him sympathetically how he had slept-Archie, Gisbert and the steward all sleep in the fore part of the deck-house, and the bears are just outside. 


\section{WHALING AND BEAR-HUNTING}

Gisbert snores, and the steward coughs alarmingly, and the bear shouts, so Archie says he has not slept a wink for nights. "Nay, nay," said Pedersen, "no mans can sleep, der is Gisbare, he go snore, snore, und dem fordumna icebears dey go roar, roar, all de nights-no man can sleep noddings!"

At night we are in the open sea, rolling south-east, and try to hit off the north of Norway somewhere. The sun almost sets now, there is at any rate the warm glow of sunset, it pours into our two cabin ports from the north, making two golden discs wave up and down on the white walls that look quite green in contrast.

The guitar is mended, the glue gave way with the fog in the ice and the heat of the stove combined. So again we have music, Gisbert the principal performer, the writer

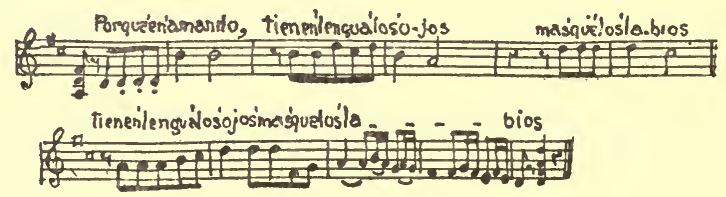

causing some surprise at his remembering part of a Spanish love song picked up in Southern Spain. Gisbert sings a number of these queer folk-songs, with their strange airs and unexpected intervals and the beat of Africa in the heart of them.

I insert the scrap referred to above. It is not everyone who cares for this minor music, but it draws tears to a Spaniard's eyes; and it appeals to the writer, inexplicably, for we have no music like it in our country.

The words amount to this : that in love, the eyes are as eloquent as the lips.

We have to play and hum tunes to keep our minds off the deep sea roll, that after the stillness of the ice comes as almost too much of a good thing. 


\section{CHAPTER XXXVI}

O-DAY it is almost rough, a fresh north-east breeze, and as our little ship rolls far and often in a swell,

1 or anything like a sea, strong men turn pale and say they feel a little tired and will go and lie down.

Killers appeared at middag-mad, and but for the excusable lassitude of our party we might have tried for one, even though it is a little rough for accurate harpooning. Their great black fins, "gaff-topsails," sailor-men call them, cut through the water with a spirt of foam like a destroyer's bow. Some say they use their dorsal fin as a weapon with which to attack large whales from underneath (Balænoptera and Mysticetus), but I do not believe this, for it is not sufficiently firm to do harm.

Some have higher fins than others. I feel afraid to mention the length I have seen them myself, or to quote the height another observer has given to me; but I think we may say eight feet and be well on the safe side. Others are only about two or three feet. In the Antarctic ice I have often seen them going along the edge of a floe, and our men stated that with this fin they pulled the seals off the edge of the ice into the water, but verily I do not believe them. The same men vowed that the Cape pigeon, which they saw for the first time in their lives, a chequered black and white petrel (Daption capensis), was a cuckoo. They wcre quite sure of this, for one of these Dundonian whalers had once spent a summer on shore and had seen a cuckoo! That was in the memorable year when he saw ripe corn for the first time.

Another excuse we make to ourselves for not pursuing these whales is that they do not have very much blubber; still, if we fall in with them again in little quieter water when we all feel fit, we may take some. When you get fast to one of these killers the others hang round till their companion is 
quite dead, much as sperm whales do, and even try to help their harpooned friend to freedom by giving him a shoulder on either side. Bottle-nose whales do the same, so when you get one on a line you run it till you secure some of the others. Big finners generally bolt in a great hurry and leave their harpooned relatives to look after themselves, excepting young finners in apron-strings, which will also hang round the parent.

Dr W. S. Bruce told me that when he was on H.S.H. the Prince of Monaco's yacht with a boat's crew they tackled one of these killers, and the unwounded killers came so close to the boat they could touch them with their hands. What must have been most interesting and instructive was the fact that the skipper who did the harpooning had been a Peterhead whaler and he knew all the expressions appropriate to the first rush of a whale in four languages-Scots, English, French and Italian-and he used them all. These killers run to twenty or thirty feet. With really big whales, heavy harpoon, big gun and huge lines, the whole business is so gigantic and awe-inspiring that men are silent, breathlessly so! But with lighter tackle somehow or other there is usually a good deal of small talk. This killer thrasher grampus or Orca gladiator, Tyrannus balænarum, has great teeth and eats whales piecemeal, porpoise, seals, and, some say, his own kind.

An accepted Danish authority, Eschricht, declared he opened a killer, and it contained the remains of no less than thirteen porpoises and fourteen seals. Personally, I do not understand how, even with two stomachs, a thirty-foot grampus could hold such a lot, unless they were very small specimens. The reader may not be aware that many whales have two or more stomachs, like ruminants, but whether they rechew their food is doubtful. The immobility of the tongue, and in some species the absence of teeth, is supposed to make this improbable, but to the writer this immobility of the tongue is not proved; it seems to be a great purple pillow covered with innumerable nerve points which might readily break up the small shrimps on the rough, mat-like surface of the whalebone palate. If they ruminate, and that under 
water for hours at a time, it would account for the way they sometimes appear all at once in numbers and feed voraciously, and then vanish for hours.

I have made a picture of a pack of rather small killers attacking a finner whale, an incident $I$ observed in the southern ice from the distance of two or three yards. They pursued the large whale like a pack of black and white hounds, but neither whale nor hounds made a sound that I could hear.

Dr Frangius, however, in his "Treatise of Animals," says that when an orca pursues "a whale" the latter makes a terrible bellowing, like a bull when bitten by a dog. I wonder what kind of whale he refers to, for I have seen $\mathbf{a}$ number of finner whales being attacked by orcas and have not heard any bellowing, except the narwhal, whose groan is certainly like a subdued bellow of a cow.

Yesterday we had wind, and the sky that portended wind if any sky does. When you have this sky it is almost safe to prophesy wind-say three days of it-this is our second day.

We make one mile an hour forward. We are a hundred miles off Norway and hoped to be in soundings fishing cod at two A.M. to-morrow on the coast. But here we are plugging almost at the same hole, our poor wee ship throbbing with the strain. We carried away our mainsail yesterday - a thing to make a yachtsman weep; still, after all, it was a sail, and even one sail on a steamer gives dignity. Don Luis Herrero in the lee alley-way just cleared the halyard block. Had he not been very quick in his movements, as many Spaniards are, he would have been a dead man. Starboard bear broke half out; that is nothing new. William has learned the mandolin, he has a piece of wood in his cage, one side of which is crossed horizontally with stout wire, and with the wood, holding it in his teeth, he scrapes the wires up and down and plays three notes for ever and for ever. I do hope that, in whatever zoo he may become a resident, he may be provided with a similar instrument with which to fill his life. He, as far as I can see, now makes no effort to escape like his big relative the Starboard bear, who is more 


\section{WHALING AND BEAR-HUNTING}

of a mechanical genius than an artist. William's sister Christabel behaves well on the whole, takes lots of tinned milk and water. Poor old Starboard, he really looked pathetic after his big effort this morning; he is black, or brown-black now, as I have already mentioned, and his black eyes, by contrast, look light brown, so does his nose. No one would take him for an ice-bear. His voice changed after the effort, and he made a sort of piteous sound instead of challenging and held his mouth open, and I suggested water, and Archie poured a pail of fresh water into his feeding drawer from a chink in the roof of the cage, and he eagerly lapped it up and went off to sleep. They have plenty of salt water-a small sea came over the bows a little while ago, and swept away every chip they had torn; incidentally it swept into an open bunker and nearly drowned the Prophet, who was acting as stoker in the engine-room. He came on deck looking rather wet and depressed and fossicked round and got the cover of the stokehold closed; it was under a bear's cage, so it was not so easy. In the ice the Prophet was a jolly bear-hunter, with lasso round his shoulder (which he could not throw), also he was clean and "the Prophet." With such yellow curly hair and eyebrows and blue eyes and pink, clean face he seemed essentially an ice-man; it is rather a come-down to be merely a black stoker homeward bound at the end of a cruise, and with nothing to prophesy.

My word, it is time to shut my cabin door on this early morning. Starboard bear and a starboard cabin! and the bear awake and growling hell and thunder, and a big sea running too. Blow his money value we say!

Everyone is rather tired of the violent ceaseless movement and the drenching of spray, but our two youngest Spaniards, in heavy coats, make merry over it, sitting up on the bridge and chatting and singing continuously, pluckily keeping their spirits up. I think they would do the same even if we had a full-fledged gale.

Our musical steward, sad to say, has felt the roughness of the trip, fog and wind combined, and this afternoon we were anxious about him, rolled him up very tight in blankets and put a hot bottle at his feet, for he was throwing up blood and 
seemed about to die; in fact, he looks a dead man now. Hamilton too is feeling tired and lies down. Altogether we would be glad to be up some fiord fishing cod for the sake of the rest and fresh food.

We had a gleam of sun from the north to-night, golden precious sunlight; it touched waves far away in front of us till they were yellow as golden guineas, while the crests near us were colder, more sickly white than silver or thawing snow.

Every cloud has its silver lining, but give me the touch of gold on the crests of long waves at the end of a gale, half the crest radiant, and the side in shadow cold, bluish white.

But our short-lived sun-gleam fades and we are all in grey - the timbers creak, creaking anxiously, sorely, and we plod along, two miles to the hour at the best, our disreputable sail set again,- - a subdued crew longing for land.

One comfort about this wooden craft is, that she was built for bottle-nose whaling and has bulwarks. The modern steam-whaler is somewhat smaller and has no bulwarks, only a rail, because she must offer as little resistance as possible to a rapid side rush of a big whale. So in such weather, even in this half-gale, they would be under water all but the bridge, whilst here we can go nearly dry-shod behind nearly two and a half feet of bulwark, behind which our too-strong she-cook in slippers can easily dodge the little water that comes on board.

Seven-forty P.M.-An interval here of twenty-four hours.

It would take each of us books in black margins to describe the melancholy of the gale; not a very severe gale, with only low waves for the amount of wind, but they are hard, and telling on our little home. It is remarkable what low, hard waves we have here. South of Norway, with similar strength of wind, I am sure the waves would be twice the height, but here they seem very hard and give heavy hits for their size. South in the sub-tropics, with half-an-hour's wind, I have seen waves get up twice as high as those we had last night, which were not a bit dangerous-have had them over the bridge, soft and warm, and no harm done; here 


\section{6}

WHALING AND BEAR-HUNTING

a wave that size would do a great deal of damage. In the north I expect this is due to the greater density of the water owing to its lower temperature.

- . Gale all night, falling in morning, leaving an abominable swell.

Sight land through mist, rain, heavy swell, everyone very tired of life. Trying to make out where we have got to.

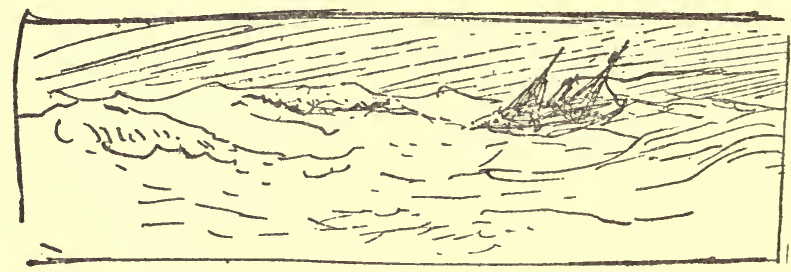

Made this jotting in night. It is not elaborate, but I think it expresses a certain amount of movement.

And this is a single-line description of the appearance of Norway as you approach it over the swell. A one-line

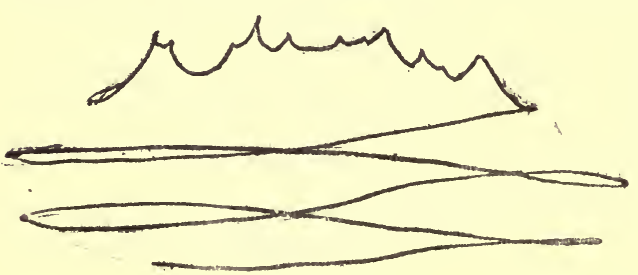
drawing of swell and mountain-tops. Why make two lines when one is enough?

In Tuglosund, the north entrance to

Trömso fiord, we find stillness and twilight.

On this sad occasion, 9th of August, we have again to light the midnight oil, or put it down "candle," in my cabinmidnight sun versus candle, and the candle wins. There is absolute stillness, not a sound in the fiord but the gentle throb of our engine.

How sad it is to lose the light.

It is almost incredible, the tranquillity of the dead-still water as we lie at anchor fishing cod-breathless stillness, so quiet one does not know how to go to sleep, no more bracing of limbs now against the side of the bunk to steady one's restless slumbers. 


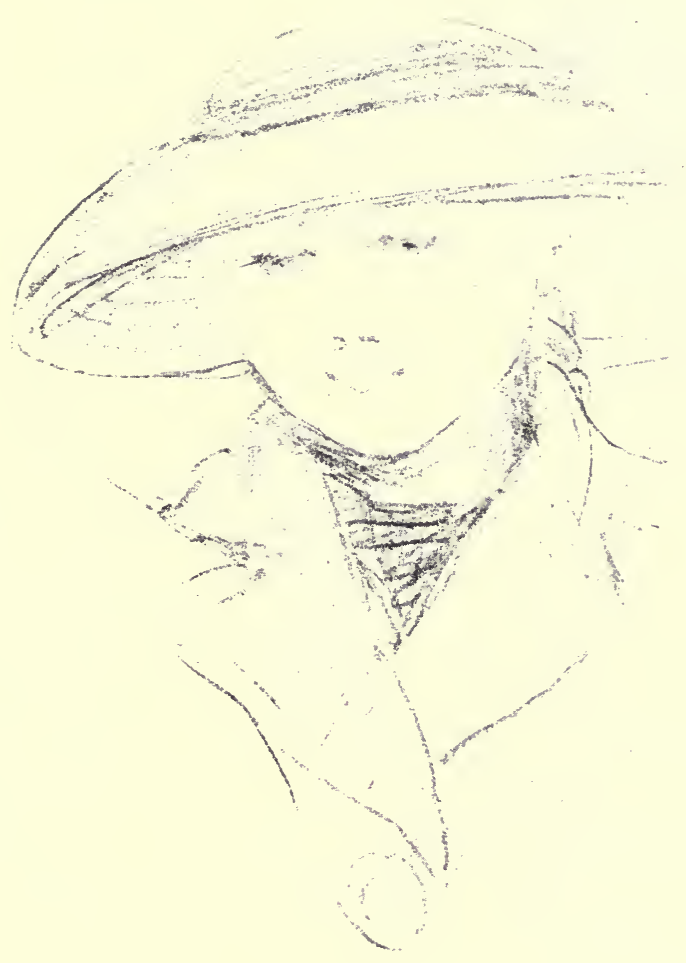

Our Engineer's Daughter at Trömso 
$\because$ 
. . . Larsen has gone ashore for fresh milk and also fresh eggs, rowing across the reflections of hill and rocks.

The candle burns straight up without a flicker ; last night we could not have lit a pipe had we felt so inclined-what are we to do about clothes? Suddenly we feel our double winter clothing is far too thick; can it be possible that tomorrow morning we will only need thin summer clothes?

As we fished we talked more intimately than before. I found my Spanish friends had been in our West Highlands ; they compared this fiord with Loch Etive, and Ben Nevis to a snow-capped mountain we have reflected in the still mirror, and they say the hills remind them of their own-Spain, West Scotland, and West Norway do indeed have certain similarity.

But the quiet! and the candlelight and the soft northern midnight twilight in the fiord, and the ripple of the boat coming back with the milk are great things! to be remembered by themselves for ever and aye.

If our night at anchor at the entrance of the fiord was quiet and peaceful, Trömso on a Sunday felt even more so. We came in with a brisk breeze blowing sharp ripples on the sheltered strait or loch, and were thankful to be under shelter, for the same breeze off the hill-side, clothed with alder and heather, would be a different thing a hundred miles north by west.

Even our bears seem to be at rest. By the afternoon we have all got shaven and shorn, and into more townified clothes, in some cases to advantage, in others not so. The blue jacket with brass buttons of the styrmand gives him far more of an air than he had with his old weather-worn pea jacket. But De Gisbert is ruined. The old Gisbert, the bear-killer, and the new F. J. de Gisbert would hardly recognise each other. Polar Gisbert in a great thick, deep blue Iceland jersey, broad-shouldered, deep-chested, with black beard with a wave in it, and black hair unbrushed and curling, a vermilion-and-white spotted handkerchief round his throat, loose corduroy knickers and wooden clogs like a Dutchman, was a picture of the jolly deep-sea piratical-looking Columbus we know. But this Gisbert! of Hamburg and Madrid, in a 
quiet blue serge suit, with trousers, and brown boots low at the heel, and a white collar sticking into a closely cropped black beard, and straight combed-out hair, and a straw hat! might be anyone !

C. A. H. does not change his get-up much, but when he goes home to hang his bearskins in the ancestral hall, he will have to do so. Sisters hate beards.

They, the Dons and Gisbert and Hamilton, have all gone up the hill to be entertained by a local magnate to-day. I

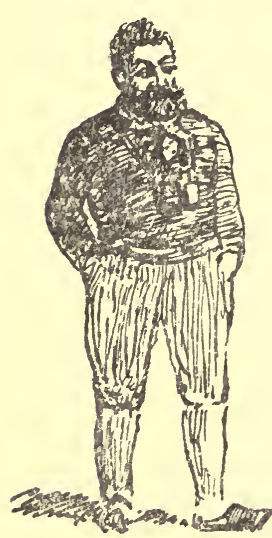

was asked, and was there before, on our first visit, and it was quite charminggramophone music, cigars with red and gold bands, delightful whiskies - and - sodas, and nice cosy rooms, with the windows all shut. But the cut on my left foot felt painful on putting on

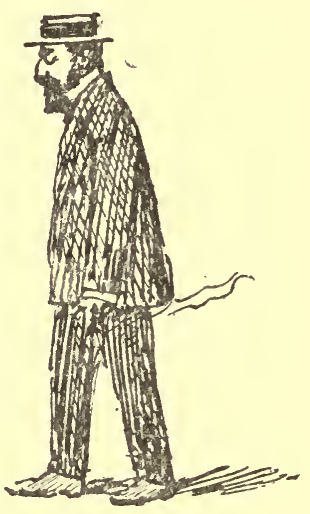

shore boots, and the house being uphill I felt obliged to deny myself the pleasure, and passed a very quiet afternoon on board. The engineer's children came off to see me (and incidentally their father). The eldest was about twelve, I think, and they talked Norwegian to me, and opened their blue eyes wide and puckered their fair faces with wonder, when they found I could not understand their little words, however distinctly and slowly they said them. They insisted then on my playing the pipes to them again, and apparently were hugely pleased.

I was sometimes sorry for the engineer's lot when we were at sea, in bad weather, for he is pale, rather like a gentle Louis Stevenson, and seemed to have little to interest him at sea beyond the engine, but now I do not pity him for his welcome home from such a beauty of a daughter, with such jolly blue eyes, so full of wonder and fun. The whole family looked over my pictures and were interested in ice-bears 
(Is bjorn) and ice-floes, but I think they were more fetched by a picture of the Fonix, done this morning, of the effect yesterday morning at three o'clock in the gale. I daresay they realised from it what sort of a life their poor dad leads sometimes-at sea.

By the way, it was not a dangerous gale, though tiresome and uncomfortable. But to show how differently things strike people, I heard that our two youngest Spaniards, who spent all night on the bridge, apparently as jolly as could be, chatting and laughing, believed all the time the ship would very likely go down-plucky of them, I think. And yet again, when we were in danger of being pinched between two ice-floes a few days previously, they were joyously potting skuas and gulls on the floe, without an idea of the danger, whilst the writer was hopping about like a hen on a hot girdle, with apprehension.

Hamilton will not look at this picture, it makes him simply squirm, which is rather flattering to the artist. Just now he says: "It is too beastly like." I must show him it again, perhaps after many days-say in a London or Clydebank fog in November. Perhaps pleasure will then be what past pain was. 


\section{CHAPTER XXXVII}

W

E find little difference here in Trömso since we left for the cold North. Then it was sunny but very cold, now all the snow has melted away from the hills and they are green with belts of dark alders that run up the corries from their reflections in the calm fiord. The rough main street of wooden houses presents the same series of little wooden doll houses, some made of upright planks, some of horizontal, in subdued harmonies of weathered pale green, blue, and worn slate, which would be a little sad but for the summer dresses of women and children, bright splashes of colour-scarlets and pale blues, vivid but harmonious, only a little noticeable on account of the uniformity of the black and dark blue clothes of all the men.

Is it coming back from the Arctic, where there are no people, or is it the atmosphere of Trömso that makes the character of each individual seem so distinct? You could sketch any of the figures, men or women, in the brightly painted street of doll houses, and the drawing would be recognised by anyone in Trömso.

Everyone seems to be at least on a bowing acquaintance with every second person he meets. Opposite this Grand (wooden) Hotel I see two of our men in dark suits and bowlers, each has a little tobacco in his cheek. I know this because I saw them put it in almost on the sly; each doffs his bowler as some acquaintance comes up. Larsen has barely time for one whiff of his cigarette between the sedate bows which they make to passers-by. Who could believe that a few days ago he was in old blue dungarees and sea-boots, hauling with us hand over hand on a narwhal line-and Larsenit is difficult to realise that a week or two ago we saw him skeltering over a floe, a long, dark figure against the ice, 
blazing black powder cartridges and splashing bullets at three yards' range into the ice in front of a three-year-old polar bear's nose, to turn it. It strikes me that the way these fair-haired men stand, and move their heads, and their type of face, is rather like the men of Berwickshire or Selkirkshire. You could hardly tell a Selkirk man here from a native, but the average man of Trömso is perhaps smaller and thinner.

The women here are not so well grown and good-looking as those in Trondhjem. Half the men are teetotallers, at least in public. I saw rather a remarkable sight here at the table d'hôte, six men at table in a row, "travellers," I think, each with a large burgundy or claret glass full of new milk beside his plate-very different in habits and the appearance we associate with their deep-drinking Viking forefathers. It really does look as if with milk drinking we may yet have peace to be amongst all men.

We go down the coast between the islands in sunshine-little cloudlets round the greystone peaks in the blue sky. This day is the Glorious 12th, and we are far from homeand we are more than content, to be comfortably on shipboard, glad to leave the northern ice regions, and yet we know that in six months' time

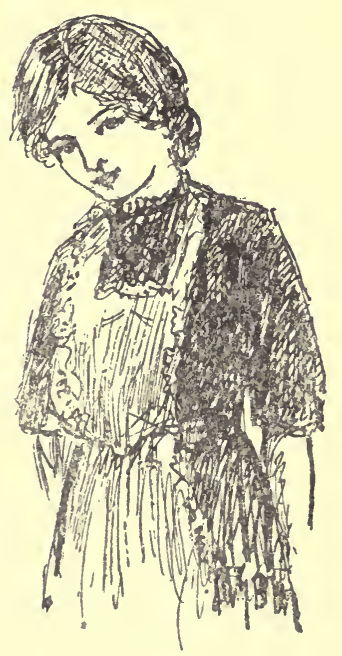
we will long to return. We watch the hills go past in luxurious repose from the luggagecovered decks-lovely hill-faces, wooded elk ground below, and higher up, slopes, with scrub and heather, just the place for dal ryper, the counterpart of our grouse, bar the white flight feathers, and above, the heather-grey rocks and stones, where you find the Norwegian ptarmigan; a glorious country, and so like our own.

No wonder in the ancient days our forefathers exchanged visits from these fiords to our Highland lochs and islands, 
and from old Alba to Lochlin, as described in the tales of the Ossianic times-friendly visits for feastings and marriages, and more often on bloody forays.

I wonder if the gentle ancestors of this little smuke pige that waits at our table formed one of the attractions of these round tours by our fathers. How delighted she was to stand for a few minutes and to have her portrait presented to her. On the previous page there is a fountain-pen ink jotting of what I remember of the original. Is she not a familiar type? We might meet her in Kent or Caithness.

I forgot to say we made arrangements, before we left Trömso, about our Port and Starboard bears. The Port bear goes to Spain, and Hamilton and I take Starboard to Edinburgh, to present him, between us, to our new Scottish

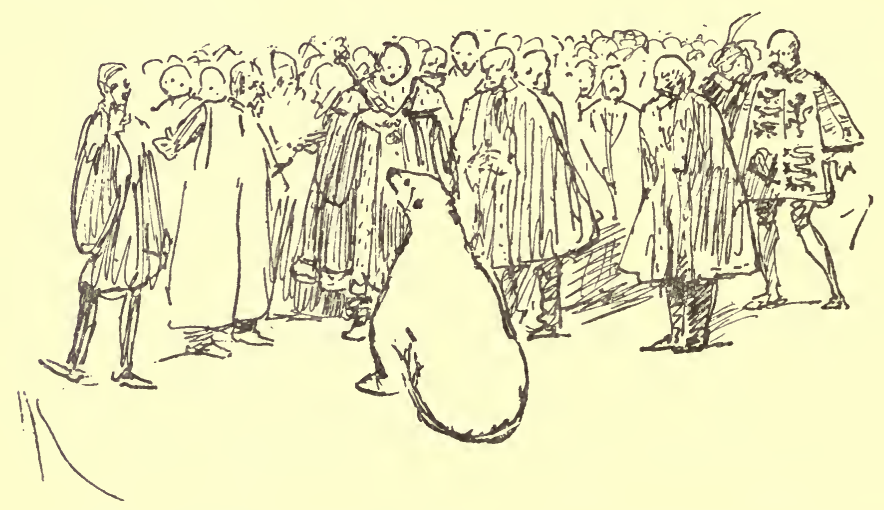

Zoological Park, which promises to be the best in the world, and of which this writer had the honour of being first Honorary Treasurer ! We will hand it over with the greatest pleasure, and then modestly withdraw; for the more you know of these two bears, the more you become of a retiring nature. I think we must have our Lord Provost to grace the ceremony of its presentation to the Park. The Right Honourable the Lord Provost, in his scarlet and ermine, and all the bailies, in reds and purples of various tints, what a grand spectacular effect! (Our company, we hope, would be excused.) And the Lord Lyon King-at-Arms we would have to come too, for colour effect, vermilion and gold, in his 
English tabard.-Ghost of Sir David Lindsay! with only one wee lion; and in the second quartering!

Fancy the bear's contemplative pause after the address of welcome and before it has decided what part it will take in the ceremony. I must make a picture of this in oils.

Our Spanish comarados intended to take their bear to Madrid, but they hear the temperature there has lately been one hundred and twenty degrees in the shade, so they fear it would melt, consequently they decide to build a large iron enclosure across a small river which runs through their estancia and the cork woods of their northern hills. There was such a den or prison already in Spain, where I am told the bear, also a polar bear, worked out an honourable old age, fishing salmon and trout for the family of its owner. It must be a pretty sight to see a white bear beside the foam of a fall, waiting its time to clip out a silvery grilse or salmon.

The process of discharging a cargo of live polar bears is fraught with considerable interest. If they escape their captors' ropes and chains they go overboard, and as happened here, two got loose and landed at the fish-market steps. Trömso natives are accustomed to visits from all sorts and kinds of people and beasts, Grand Dukes and Laps, walrus, whales, and bears, but not bears at large. They fled, and the bears tucked into the fish stalls, and the bill for their lunch amounted to one hundred kroner $(£ 5,10 \mathrm{~s}$.)-probably any other visitors might have bought all the fish in the market that day for ten kroner. They fortunately took to the water again after their meal, and were recaptured. Once a walrus escaped at Trömso from board-ship, and it also took to the water, and it was also recaptured! It loved the captain's wife and she whistled to it and it came back.

Our bears' cages, all tattered wood and iron bars, were lifted, bears and all, by the winch over the side, and of course sank almost to water-level. One of the iron bars was levered up a little with a crowbar, which gave, in Starboard's case, an opening for his delicate paw, which 


\section{WHALING AND BEAR-HUNTING}

instantly came out and tore the cage to smithereens, and out he came, and, evidently to his great content, wallowed about in the sea and washed his face, and took a dive or two and rubbed his paws, saying "Bé-waugh" and "B-e-a-r" frequently, and looked perfectly happy and amiable. Just to prevent him swimming ashore and going into the fishmarket, we put a stout little rope round his neck, and he continued to enjoy his bath, whilst we made ready a new cage, each batten of which is covered with sheet iron on the inside and has the appearance of strength which I should desire for such an opening ceremony as I have above suggested, if I have to be present. When this cage was in order, our duty was to get the big strop or ring of heavy rope round his waist, so as to haul him out of his bath with our sixty-horsepower winch, and this was done with some escape of steam and some splashing and profuse remarks from the bear. Now he is in his new quarters, into which he cannot get his teeth, and he ruminates peacefully and eats and drinks what is given him. I wonder what his teeth will go into when he first comes out.

Christabel and William we are selling for much moneys by telegraph to a certain millionaire. They will make charming pets and William, as already mentioned, promises to be a musician as well, but they will never attain, in captivity, to the size that Port and Starboard may be expected to attain, for the latter have already spent several years on the floes eating seal galore.

Bears have gone up in price; very few have lately been landed, as far as we can hear, in Northern Europe. Recent years have been rather bad for expeditions. We know of several which have been wrecked; some of the crews are dead. ${ }^{1}$ Gisbert is going to hang on with the Fonix at Trömso and may go North again in search of survivors.

Slipping down the Norwegian coast amongst the islands in a passenger steamer feels very luxurious after being in such a small vessel with always a certain amount of risk;

1 I have learned since that five vessels came to grief in the year 19r3. Of one trip (Stefansen's) only one man has survived. 

and after views of ice and sea, bears and seals day after day, rocks and trees and little farms or fishermen's houses nestling in the greenery, with mountains and snow-fjeld far behind them are very welcome. There is the "human interest," which I have previously said has been remarked for its absence in the polar regions by careful observers.

... What a country this is to breed real men. Every boy in every one of these isolated farms must of necessity learn to row, to ride, to sail, to hunt, ski, handle an axe, do iron and wood work, besides his farming; and for one pound sterling a year he can be in touch with the centres of European news and civilisation. On the telephone-eighteen kroner a year they pay to send messages under the sea and over forests and fjelds to their township, say forty or fifty miles distant, whilst we belated people in these backwoods of Berwickshire have to pay nine pounds a year for the same convenience.

As I write we see two such natives enviably employedtwo small boys - the day's work done on the farm, they don't go to school in summer-they are now managing a boat and fishing. With the glass I can see the bow is almost full of cod, haddock, and some codling. The elder boy looks about twelve years old. He pulls up two at a time, shimmering, iridescent, pink-tinted haddock. Who could believe the rather plain grey fish we see in the fishmonger's could ever look like a chunk of mother-of-pearl?

Woods and islands, rugged mountains, grey fjelds, with snow in patches, pass hour after hour, till we come to the fiord of the old capital-Trondhjem Fiord. It reminds us of our Firth of Forth, on a larger scale, with more woods. For me Norway begins at Trondhjem going north, and ends there coming south. Southern Norway seems to have no tradition, no direct appeal to me. In the soft distance I can see height after height fading into the distance; to the north and east with the glass I can see the woods of Sundal in Stordal, where we have hunted elk, and seen the golden birch leaves falling, and the snowflakes drifting down into the green depths of the swaying fir woods. The water of the fiord is tinted with Stordal River. I recall its salmon 


\section{WHALING AND BEAR-HUNTING}

and hear again its solemn roar when the mist hung low in the glen. What days of exertion these were, climbing and descending under the dripping pines, two men and a hound, stealthily, silently, with hardly a word for hours, watching through the woods for the gaunt form of a bull elk, days of such fatigue and nights of profound repose, alike haunted with the sweet melancholy of the saetar songs.

Why do such merry, cheerful people as bonders' daughters sing such sad songs? Here is what I remember of one that haunts me now.
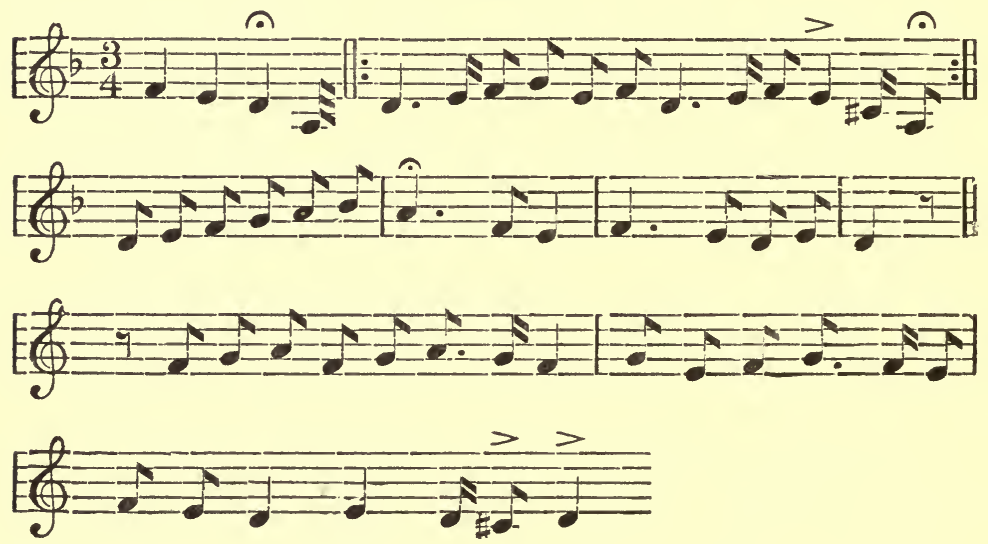

Its rhythm just suits your steps if you hum it, not loud enough to disturb an elk as you slowly ascend, step by step, through the wet pines in the morning to the high grounds, and the quick part helps you returning as you swing down the last of the hill-side from one red-leafed rowan to the next, down to the level; and months after, it comes to you when you are in a street and you see the woods and the river winding a silver thread at the foot of the glen and the welcome smoke of the log-built farm. Once I hummed it unconsciously on a dull, wet day at the quayside in Hull, standing amongst emigrants looking at the swirling and muddy river, and a Norse woman standing near with a white handkerchief for headdress began to hum it too- we could not speak to each other, but our thoughts were harking back to saetar and glen and hill-the charm of Norway. 
Another haunting folk-song I heard here years ago-I must put it down to preserve it - at Vibstadt, Namsen Valley, on a hot midday I heard the bonders' daughters sing it as they weeded lettuce in the blaze of light. They called it Barden's Dod (The Death of the Bard), and we have the same air in our Highlands ; it dates back to prehistoric times ; and we call it "The Minstrel of the MacDonalds." No one that I know sings or plays it now at home. But a year or two ago, on the top of a mountain in Southern Norway, as we rested at lunch, a Norse hunting companion began singing it, and I started, and he smiled and explained his wife was one of the little girls who had given it to me in Northern Norway twenty years before. The Norwegian words, I am told by a Norwegian antiquarian, belong to the Viking period. 


\section{CHAPTER XXXVIII}

$\mathbf{N}$ the smoking-room on the way south on board we naturally talk much about fishing, for half our fellowpassengers have been salmon-fishing and there is much comparison of Bags and Rivers. Some have done better than they expected, others growl at their bags, and the season, and at the agent, whoever it was, that put them on to such a bad river. But all are charmed with Norse scenery, and Norse people. We come in for some questioning about bears. There is no invidious comparison between a bag of bears

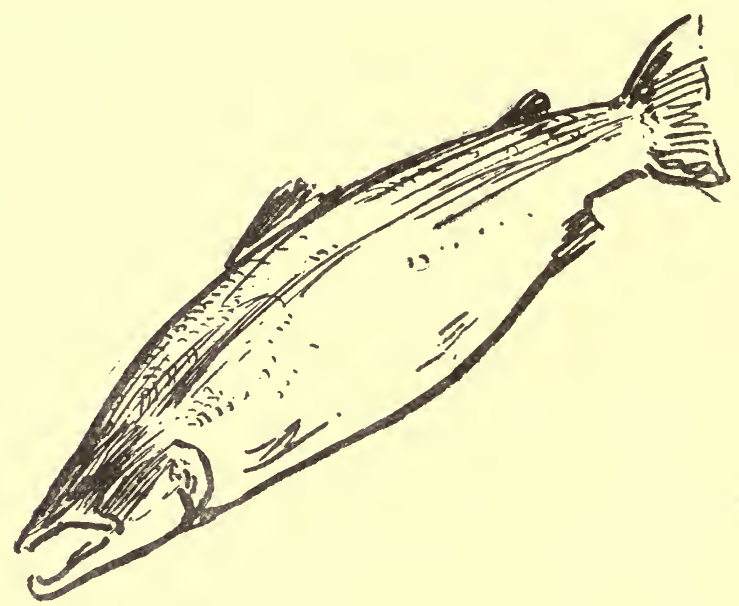

and a creel of salmon; but we have to be careful about whales, for it would be a little rough on the veteran salmonfisher to cap his best with a yarn on whales: after he has, at length and with the utmost modesty, recounted the fight his fifty-pounder put up, and the hundred yards it took out, it would scarcely be considerate to refer to some fifty-ton or one-hundred-ton whale, and the miles of cable it had reeled off in a twinkling. Of course everyone knows a whale is not a fish-still, the slight similarity is such that whaling yarns are apt to be damping when fishing stories are going; 
though the true Walton angler is happy catching any size of fish; a six-ounce trout to me, in a Highland burn, is almost as good as a whale. Notwithstanding this delicate tact on our part, whaling was introduced one evening in the smoking-room, and the writer was rather surprised to find

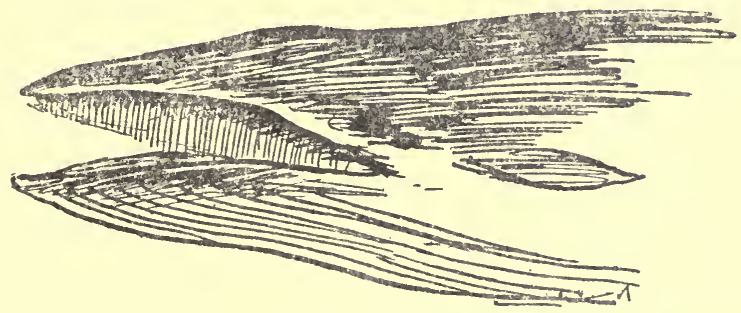

A Finner's Head

that several men had very little idea of the functions of whalebone or its place in the whale's anatomy, so we had to draw diagrams, such as these here reproduced, to describe shortly the way whalebone works. This is a side view of the head of a finner whale; it shows the outer edges of the whalebone

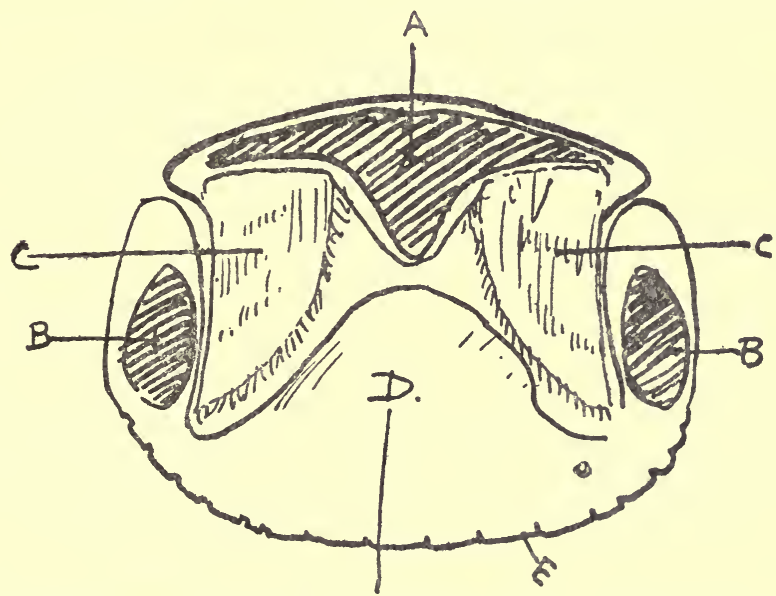

plates that hang round the sides of the upper jaw. The blades vary in thickness in different whales; in the common Balænoptera Borealis, such as this, it measures about a quarter of an inch thick and is about two feet at deepest. The blade has hair on its inside edge. If the whale's head were cut across between the nose and eye, or corner of its mouth, 


\section{WHALING AND BEAR-HUNTING}

the section would be like this. These hairs intertwine and form a surface to the palate like a well-worn cocoanut mat. The whale opens its mouth and takes in possibly a ton of water thick with small shrimps, partially closes its jaws and expels the water through the fibrous surface and out between the blades. I suppose by raising the enormous soft plum-coloured tongue ( $\mathrm{D}$ in section) towards the hairy palate or mat of interwoven hairs at the edge of each plate (CC in section) it prevents the shrimps going out with the water, and the tongue works the shrimps down to its throat. I have not calculated the food which I have seen come out of a whale's stomach when cut up, but I say, at a rough guess, forty to sixty gallons-three or four barrels of very minute shrimps. I have only seen the remains of one of the Right

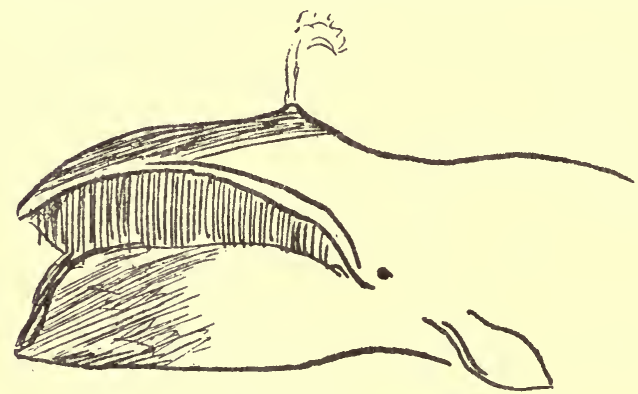

A Right Whale's Head

whale, Mysticetus, and those of the smaller, somewhat similar whale, Balæna Australis. The Right or Greenland whale had very long bone, up to eleven feet. To cover the whalebone, the lower lip is formed as in this jotting. Scoresby maintains that when the Right whale's mouth is closed, the blades bend or fold back towards the throat. This seems probable.

You see from the difference between these whales' points that the rorqual is a more athletic beast than the Right whale.

The sperm or cachalot whale's head is very peculiar. It has teeth in lower jaw and a small tongue. All the part forward of the dotted line here, which represents the skull of the head, is a mass of fibrous oil. When you cut through 

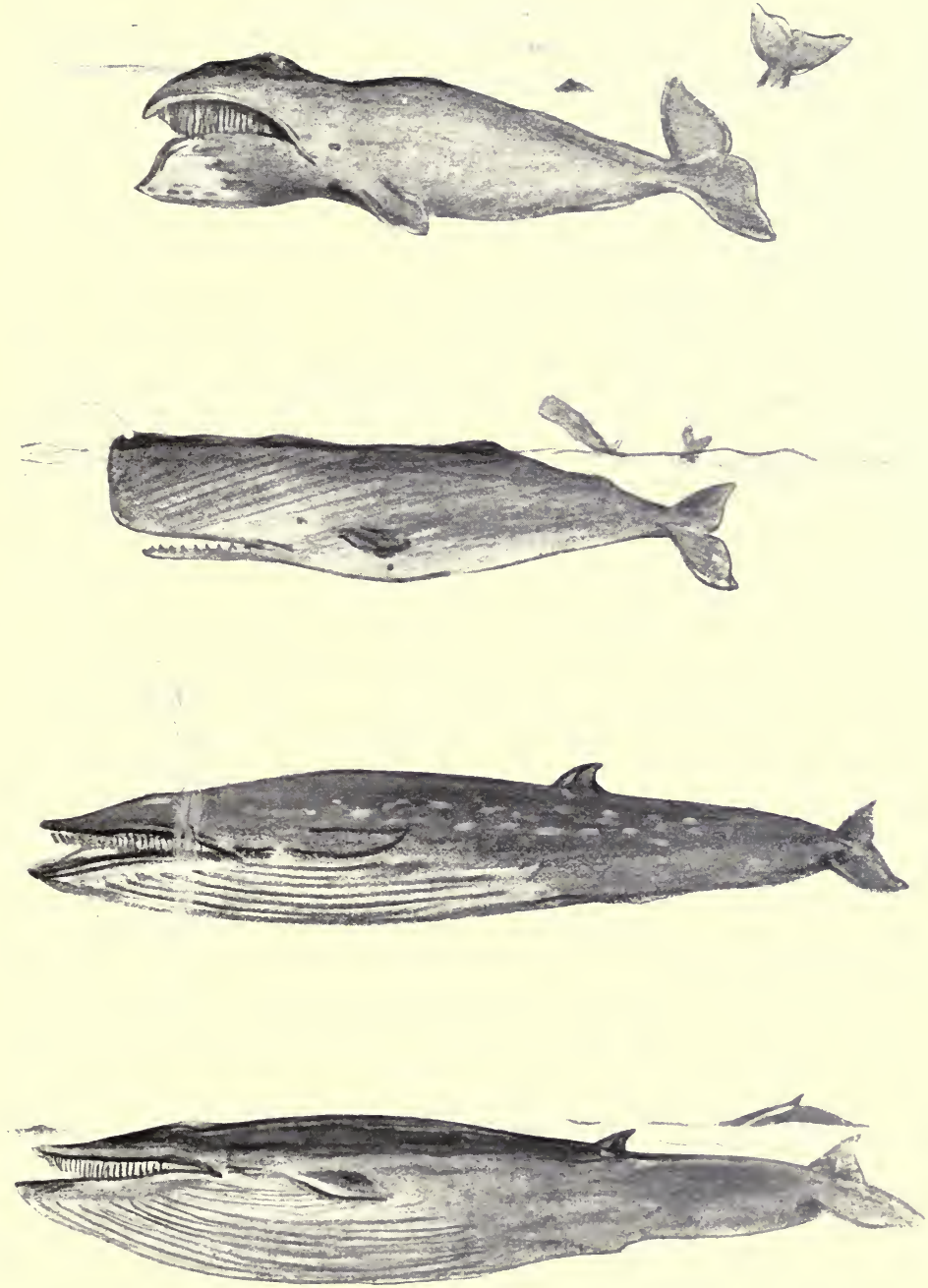

\section{Right Whales and Spera up to 6o Feet, Finners up to i io Feet}

I. Greenland Right whale, Balcena Mysticetus, up to 6o feet in length, generally found near Arctic ice. The smaller whalebone whale of the Atlantic and Southern oceans is somewhat similar in shape; it runs to 50 feet; shows tail as it dives; has no fin on back. It is called the Nordcapper or Biscayensis and Australis.

2. The Sperm or Cachalot, Physeter Macrocephalus. A toothed whale 50 to 60 feet; shows tail when it dives; sometimes breaches, i.e. leaps several times in succession as it travels; blast low and projected forward.

3. Seihvale, Balanoptera Borealis, 40 to 50 feet; blast about ro feet; does not usually lift tail out of water before final dive; has fin on back, is therefore a "finner."

4. Fin whale, Balcenoptera Musculus, up to 75 feet. The Blue whale, Balcenoptera Sitbaldii, is similar, with smaller fin on back; both make blasts about 18 feet. The Blue whale in Southern seas has been killed up to I ro feet. 

the skin you can bail it out with pitchers or pump it out till it gets too cold, after which you do not know whether to lift it in your hands or in a bucket. It is beautifully clear, no one knows why it has this extraordinary spongy forepart to its head. This sperm oil is chemically different from the oil of

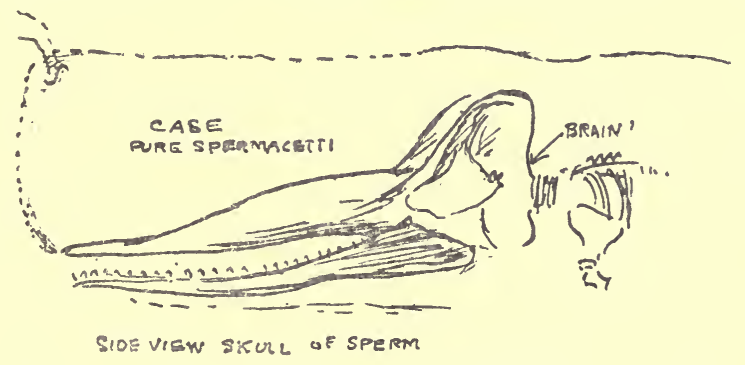

Head of a Sperm, showing Skull

other whales; it is more of the nature of a wax : the other whales are of a fatty nature. It makes the finest lubricant for modern machinery.

The blow hole is on left side of this " case," the blow pipe from lungs going through it. And the jet of steam is thrown up two or three feet and forward, so a sperm's blast is easily distinguished from that of the finner, which is bigger and straight up, say to twenty or thirty feet, or possibly forty feet, in the case of a large Blue whale. 


\section{A P P E N D I X}

\section{Old and New Whaling}

The Greenland whaling was practically given up in 1912, and the Southern whaling for sperm and cachalot and the Southern Right whale, which in the first half of the nineteenth century employed five hundred to six hundred vessels, practically stopped forty years ago.

\section{Why the Old Styles of Whaling stopped}

The growing scarcity and wariness of the Greenland Right whale and the fall in the price of oil and whalebone gave the Balæna Mysticetus or Greenland Right whale an indefinitely prolonged close season, and in the Southern Seas the sperm and the Southern Right whale (Australis) fishing almost entirely ceased, owing to increased working expenses, smaller catches, and the fall in the price of oil.

\section{"Modern Whaling" in North Atlantic}

In 1886 Captain Svend Foyn of Tonsberg, Norway, invented the plan of capturing the powerful rorquals, commonly called Finners, that are very numerous, but were too strong and too heavy to be killed in the old style from row-boats, and which till his time had not been hunted. By his process a small cannon on the bow of a small steamer could fire a heavy harpoon, one and a half to two hundredweights, attached to a four-and-a-half hawser. This steamer and line were sufficiently buoyant and strong to play the whale and to haul its body up from the depths when it sank dead. The Greenland whale and sperm both floated when they died. Fortunes were made from the finner whale hunting off the Norwegian coast.

\section{Commercial Aspect and Method of Modern Whaling}

Some of these companies work with shore factories, others with both shore factories and large floating factories on board 
steamers of up to seven thousand tons burden, and each company hunts the whales with, on an average, three to four small steamers, which harpoon the whales within a radius of eighty or ninety miles and tow them in to the shore factories, or the floating factory which is at anchor in some sheltered bay. The bodies are rapidly cut up at a fully equipped land station, and both the blubber and carcass are entirely utilised. At a floating station the bodies, as a rule, are cast adrift.

\section{Whale Meat Meal and Guano}

Whale meat meal is made from fresh whale flesh; it is used for feeding cattle. It contains $\mathbf{1 7 \frac { 1 } { 2 }}$ per cent. proteid, and guano is made from the remaining flesh and about one-third bone. The analysis of this gives 8.50 per cent. ammonia and 21 per cent triboric phosphates. The whole of the dried bones and meat may be made into one product - a rich guano with 10 to 12 per cent. ammonia and 17 to 24 per cent. phosphates. The best whale meat is better to eat and tastes better than the best beef; it is "lighter" and more appetising. The writer proposed to supply an immense quantity to our military authorities, but the offer was not accepted.

\section{Whalebone or Baleen}

The baleen or whalebone of these finner whales is only worth about $£ 30$ per ton. It hardly pays to cure it and market it. The whalebone of the Australis or Southern Right whale has fallen to $£ 85$ per ton; it is occasionally caught. Its bones and that of the finner brought down the price of the Greenland whalebone, which a few years ago was sold at between $£ 2000$ and $£ 3000$ per ton, one good whale having a ton in its mouth, which paid the expenses of the trip.

During the short season, 1st November till end of April, in a recent year the catch in South Georgia by twenty-one steamers amounted to five thousand whales, finner, humpback and blue whales, which gave two hundred thousand barrels of whale oil and eight thousand tons guano. 


\section{Returns from Whaling}

Taking in the other islands of the Falkland Islands Dependencies in the neighbourhood of Cape Horn, the catch in a recent year amounted to four hundred and thirty thousand barrels of oil-eight thousand three hundred and seventyfive tons guano, the gross value of which may be reckoned at $£ 1,360,000$. Practically the whole of this goes to Norway.

For forty-eight years this Modern Whaling has been carried on in the North Atlantic, and since 1904 the Modern Whaling which we advocated in Edinburgh in 1895 has been prosecuted by Norwegians in the South Atlantic from desolate barren British possessions, with the great results mentioned above. There are vast areas of ocean teeming with these whales where, so far, they have not been hunted, and still the general British public stands aloof and takes no share in it. Whaling to-day, from the Norwegian point of view, is an industry: three generations have been brought up on it; but from the average British point of view it is still a speculation.

\section{AMbergris}

Ambergris is a biliary concretion generally found in the alimentary canal of a feeble or diseased sperm whale. Sometimes it is found exteriorly near the vent. It is also found floating or drifted ashore. It is of great value, and is principally used as the basis or vehicle for perfumes.

Some years ago Norwegians found four hundred and twenty kilos in a sperm on the Australian coast; this was valued at $£ 27,000$. This is much the largest piece $I$ have heard of.

It is a solid, fatty substance of a marbled grey-and-black appearance, and generally contains the beaks of cuttle-fish, which form the principal food of the cachalot or sperm whale. When fresh it has an intolerable smell, but after exposure this goes, and leaves what some people call a "peculiar sweet earthy odour." It burns with a pale blue flame and melts somewhat like sealing-wax. 


\section{The Whaling Industry}

The St Abbs Whaling Limited, of which the writer was appointed chairman, found whales at the Seychelles in great numbers in 1913, and we got permission from the Government there to start an up-to-date whaling station with licences for two whaling steamers, which we chartered and had sent out to us from Norway.

Our capital was about $£ 20,000$, and our station and factory was nearly completed, and we were catching numbers of sperm and some "finner" whales, when war broke out. Our supply of coals was cut off ; barrels could not be obtained for oil; sacks could not be got for the whale guano (which is made from bones and whale meat); and freight completely failed us owing to the congestion caused by war material on the various lines. We could neither get supplies nor send away our products to Durban and other ports, except in some small consignments on our Diesel motor tank whaler, the St Ebba, which finally we were obliged to run on sperm oil at about $£ 28$ per ton!

We could not "stop down" owing to contracts; and the difficulty of raising more capital under war conditions finally forced us to voluntary liquidation.

This promising industry, therefore, had to be stopped in the meantime, and it occurs to us that as one of the "Empire's resources" the Government could very easily put it into working order again, with great profit and for the benefit of the Islands, Africa and the Old Country. For we found immense numbers of sperm and finner whales round the Seychelles, and even before getting into our stride we had secured one hundred and forty whales and shipped home two thousand three hundred barrels of oil, besides what was lost before the station factory was completed and what we were obliged to use locally for our Diesel motor in place of common solar oil. Six barrels of whale oil go to the ton.

With the experience before them of the vast revenues from whaling at South Georgia and South Shetlands going almost entirely to Norway, our Government has, we think, wisely restricted the granting of whaling licences at the 


\section{WHALING AND BEAR-HUNTING}

Seychelles to British concerns. Our company rented land for our station, built the factories and has some years' lease to run, and the best season for fishing begins about 1st of May.

The vast whaling industry in the Falkland Island Dependencies-the South Georgia and South Shetlands-was started as a result of the information that Dr W. S. Bruce and the writer brought back from there in regard to the immense number of finner whales we had seen there in our Antarctic voyage of 1892-1893 to the Antarctic and Weddell Sea; and in one of the first of the Norwegian companies, which is still successful to-day, the writer took a considerable interest at its start. This company is to-day paying a dividend of over $\mathbf{1 5 0}$ per cent. But for the war I consider the Seychelles whaling should have paid handsomely now.

In regard to this great modern whaling industry in the sub-Antarctic seas we may here say that, previously to the Norwegians starting it, Dr Bruce and the writer held meetings in Edinburgh and urged the leading business men, merchants and shipping people to take it up. We foretold the fortunes that were to be made, but they did not rise. A little later the Norwegian who we hoped to have as manager for the first whaling station in South Georgia, Captain Larsen, succeeded in raising capital in Argentina, and I am told began with a modest 70 per cent. profit in the first year. Norwegian companies quickly followed his lead and utilised our Empire's resources for Norway! 


\section{INDEX}

A

Accounts, difficulties in the, 43

Aften-mad, 72

Alexandra Whaling Station, 63, 67

Allan, Miss Sheila, 108

Ambergris, 22, 159, 314

Ammunition, 40

Anatomy of a whale, 159

Anchor, accident to our, 46

Arctic and Antarctic compared, 187, 189

Arctic Fox, 278

Arctic grouse, 278

Ardnamurchan, 107

Azores, the, 165

B

Balena, the, 51, 104

Balæna Mysticetus, 21, 312

Balænoptera Borealis, 69

Balænoptera musculus, 17

Balænoptera Sibbaldii, the, 17

Baleen or whalebone, 313

Balkan, Mrs, 31

Balta Sound, 14

Bear and cubs, 258

Bear-hunting, accidents in, 225

Bear yarns, 216

Bearded seal, 269

Bears, stalking, 193 ; dangers, 194, 196 ; size and weight, 198 ; stalking, 199, 200 ; lassoing, 210 , $213,214,215,216,217,224,227$, 241,247

Belfast, 116

Birthday celebration, a, 105

Blowing up, 87

Blue seal, 269

Blue sharks, 162

Bottle-nose whale, 282

Bowhead or Right whale, 21

Bressay Light, 55

Britannia Club, the, 31

Bruce, Dr W. S., 179

Bull-fight on deck, 262

Bull versus bear, 285
C

Cabins, 28

Cachalot, 18

Cachés, 215

Calving bergs, 271

Caribou and whale, colours of the, 94

Carros, 166

Case or forehead, 160

Casperg, Captain, 89

Chanteys, 102

Christiania Fiord, 27

Clarence Island, 31

Clothes, darned and patched, 73

Cod liver oil, 208

Colla Firth, 18

Colours in Arctic regions, 192

Colours of the sea, 77

Colours of the whale, 93

Cormorants and gulls, 60

Cormorants, on cooking, 65

"Cruise of the Cachalot," the, 22

Cubs, lassoing, 264

Customs officers, 58

Cutting up a whale, 159

Cuttlefish and whales, 254

D

DANGERS of whaling, 89,260

De Gisbert, F. A., 180

Dolphins, 127

Dreams, 227

Drimnin, 108

Dundee whalers, 21

$\mathbf{E}$

Eмвryos of whale, 94

Engine troubles, 50, 148

Explosive bombs, 23

F

Factories, shore and floating, 313

Falkland Islands, 24, 314 
Finners, 312

Flippers of seal, 240

Fogs, Arctic, 279

Fonix, the, 180, 181

Food of the whale, 251

Football, 219

Foyn, his wife and a whale, 232 ; diplomatic steward, 233

Fuel, oil, 28

Fulmar petrels, 212

Funchal, 165

\section{G}

Gear for raising dead whale, 87

Geraniums, 165

Gisbert and the bear, 216

Graham's Land, 23

Grampuses, 148

Greenland, 267

Greenland whales, 24

Greenland Right whale fishing, 21, 312

Guano, 24, 84, 313

Gun, the harpoon, 29

Gun and harpoon, old style, 231

Gun, loading the, 88

Guns, light versus heavy, 222

\section{$\mathrm{H}$}

HaLdane family, stories of the, 66

Haldane, R. C., 64

Haldane, the, 17

Hamilton, C. A., 180

Hansen and the bear, 217

Harp seals, 258, 275

Harpoons, 29, 312

Hawsers for big whales, 24

Head of whale, 90

Heavy seas, 122

Henriksen, 18, 19, 29, 32, 119

Henriksen, Harold, 29

Herring-hog or springer, 69

Hospitality, Norwegian, 34

Hydrangeas, 139

\section{I}

ICE colours, 201

Ice floes, 248

Icebergs, 187

Ivory gull, 182-212

JACKARANDA, the, 165

Japanese whaling grounds, 18, 57

Jensen's store, 33
K

KiLLer, A., 47

Knarberg, 39

L

Lagopus hemilencurus or Arctio grouse, 278

Lancing a whale, 93

Larsen, Captain, 41, 316

Lasso practice, 250

Lassoing a bear, 210, 285

Leigh Smith, 215

Lerwick, 54, 55

Lifeboat, an extravagant, 51

Lighthouses, 106

Lochend, 18, 65

MACKEREL, killing, 72

Madeira, flowers, 165 ; tunny-fishing, 166 ; sunrise, 168 ; boats, 169

Magazine ship, 24

Magnus Andersen, 60

Mainmast, our, 41

Meals on a whaler, 71

Measurement of bears, 238

Meat meal, whale, 313

Messroom and galley, 28, 49

Middag-mad, 71

Mishnish Hotel, the, 113

" Modern Whales," 22, 24

Monaco, Prince of, 94

Motor versus steam-engine, 106

Motor whaler, a, 19

\section{$\mathrm{N}$}

NaRwhal-Fishing, dangers of, 238

Narwhals, 204, 228, 229, 234, 237

Natural colours and surroundings, 200

New Bedford sailing ships, 21

Nordcapper, the, 26

Norse sporting guns, 121

Norwegian ladies, 30

Norwegian pilot-boats, 18

\section{O}

OBAN, 110

Oil and coal, 117

Oil, value of, 83,84

Oil, whale, 24

"Old man Henriksen," 43

Orca gladiator, the, 47 
$\mathbf{P}$

Partings, 45

Pet bear, a, 257

Pilot-fish, 162

Pine trunk, a drifting, 220

Phosphorescent sea, a, 124

Photography, 245

Physeter Macrocephalus, 69

Plankton, 253

Pod or herd, 92

"Polar Research," Bruce's, 192

Ponta Delgada, arcade, 132 ; boats, 133 ; fish, 135 ; Robert's café, 136 ; a wreck, 135 ; hydrangeas, 139 ; shops, 140 ; the Atlantico, 140 ; dress, 141; whales, 142 ; the sea, 143; the Seven Cities, 151

Port and starboard bears, our, 265

Protective colouring, 192, 276

Pussy finger, 209

\section{R}

Ramna Stacks, the, 100

Red-tape entanglements, 60

Registration bothers, 60

Restrictions, 83

Richardson's skua, 212

Right whale, 21

Robertson, Captain T., 25

Romance of the sea, 129

Rorquals, 19, 312

Runners, 119

Ryvingen Light, the, 47

S

SAGA, Jansen's, 34

St Ebba, the, 19, 27, 35, 38, 48, 97

St Abb's Whaling Limited, 315

San Miguel, 130

Scoresby, 179

Sea legs, 157

Sea-sick crew, a, 48

Seal-hunting, 208

Sealers, 183

Seals, Arctic and Antarctic, 188

Seals, Vitulina, 191; Phoca Barbata, 197 ; Cystophora Cristata, 203; blue, 269 ; Barbata, 269 ; harp, 275

Seven Cities, the, 151

Seychelles, the, 176, 315

She-cook, our, 206

Sharks, 159, 207, 208

Shetlands in pawn, the, 60

Shoppie, a, 125
Shore stations, 24

Sing-song, a, 99

Sorrensen, the brothers, 31

South Georgia, 31

South Shetlands, the, 31

Spanish National Polar Expedition, 180.

Sperm or Cachalot whale, 22, 312

Spitzbergen ice, 287

Sports on the ice, 279

Spotted mackerel, 169

Spy, a, 113

Squalus Borealis, 207

Stalking and being stalked, 199

Starboard bear, the, 263

Strength of the bear, 245

Sumburgh Head, 55

Sunday observance, 125

Sven Foyn's harpoons, 23, 312

Svendsen, 180

\section{T}

TACKLE for whaling, 232

"Tail up," 88

Tail of a whale, the $\theta 7$

Tanks, 28

Teeth of seals, 269

Tobermory, 108

Tongue of the whale, 254

Tonsberg, 19, 21, 27, 30, 33 ; whaling industry, 233

Torp, Captain, death of, 89

Trammel net, a, 134

Trolle, Captain, 179

Trouble with captive bears, 248

Tunny, 164, 166

U

Ulstermen and Scots, 118

Union Jack, our, 110

Urmston, 110

\section{V}

VIKING ship, 21

Vulpes lagopus, or Arctic fox, 278

W

WADING stockings, advantages of, 209

Weddel Sea, the, 23

Whale cooker, our, 161

Whale flesh, 83, 91

Whale's food, 101 
Whale gun, the, 69

Whale lines, 28, 33, 87

Whale products and their prices, 83

Whale steak, 72

Whalebone, 21, 24, 83

Whales, Balænoptera Sibbaldii, 17 ; Balænoptera musculus, 17 ; Balænoptera Vaga, 69; Right whale, 18, 21, 58, 232, 254 ; Cachalot, 18, 21 ; Sperm, 18, 22, 155 ; Finners, 19, 22, 69 ; Balæna mysticetus, 21, 58; Biscayensis, $25,58,69,83$; Orca gladiator, 47 ; blue, 69 ; Seihvale, 69, 83; Ziphius novae Zealandicoe, 144; narwhals, 204; Hyperoodon diodon, 282

Whales and cuttlefish, 158
Whales, habits of, 156

Whales, harpooning, 77, 81, 86, 92, $155,157,176$

Whales, size of, 84

Whales and trout, 76

Whaling, old and modern, 21, 314

Winch, the, 28

Wives at sea, 111

Wounded seals, 260

Wreck, a, 136

\section{Y}

YACHT club, Tonsberg, 30

Yell Sound, 69

Yule, 108

Yusako, 32 





\section{UNIVERSITY OF CALIFORNIA LIBRARY BERKELEY}

Return to desk from which borrowed.

This book is DUE on the last date stamped below.

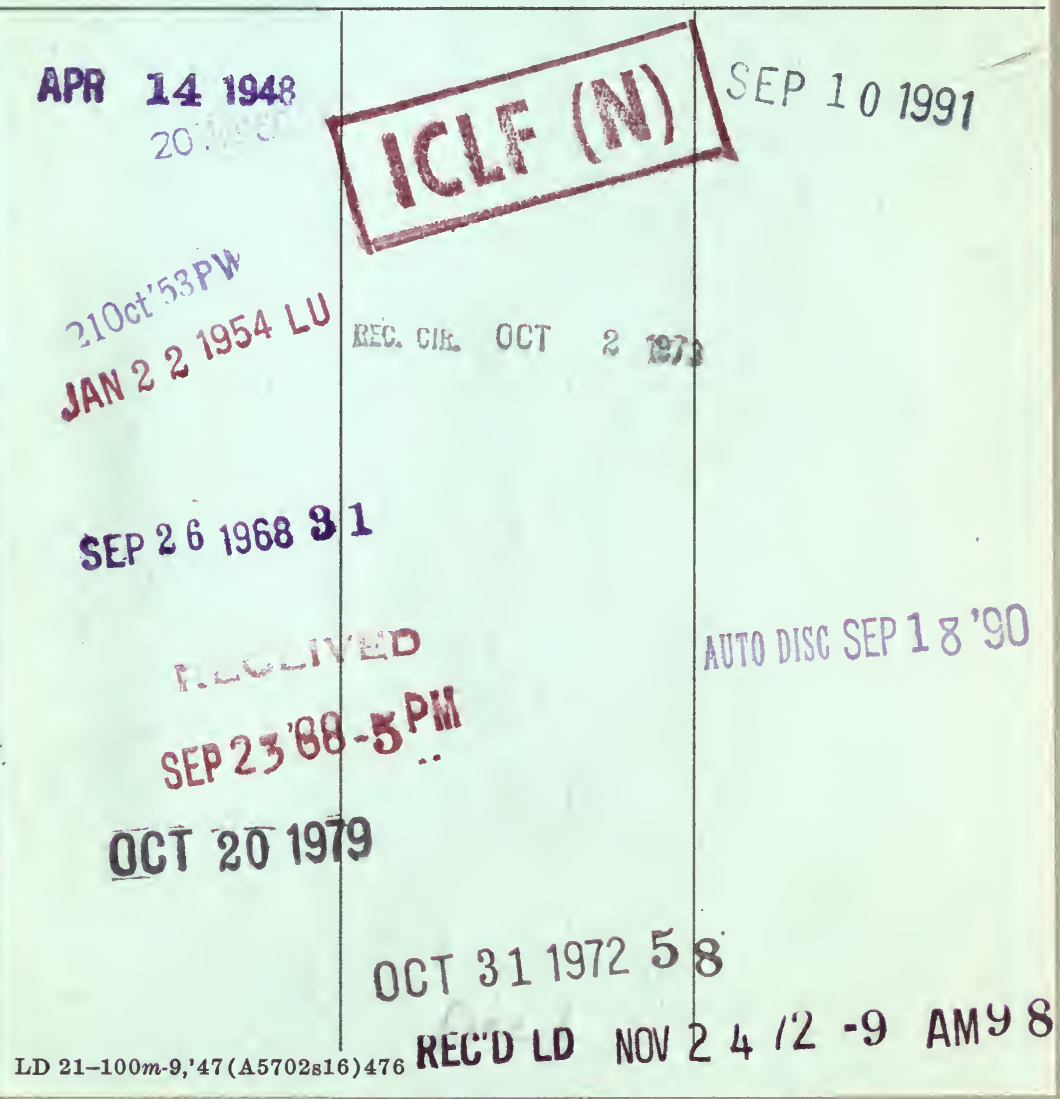


IIIIII II U.C. BERKELEY LIBRARIES

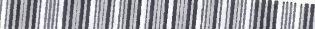
$\operatorname{co3} 1963833$

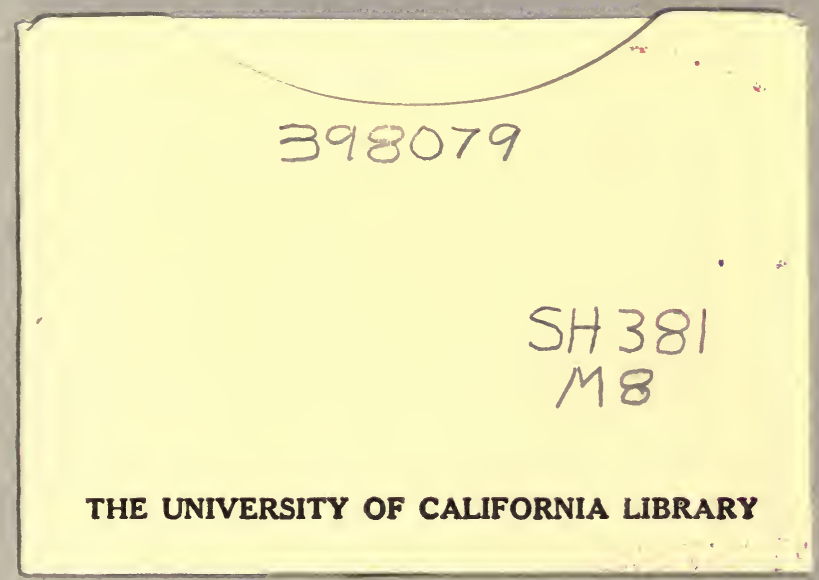


